\title{
Comparative study of salt stress-induced physiological and molecular responses in tomato (Solanum lycopersicum L.)
}

\author{
Ph.D. Dissertation
}

Judit Kovács

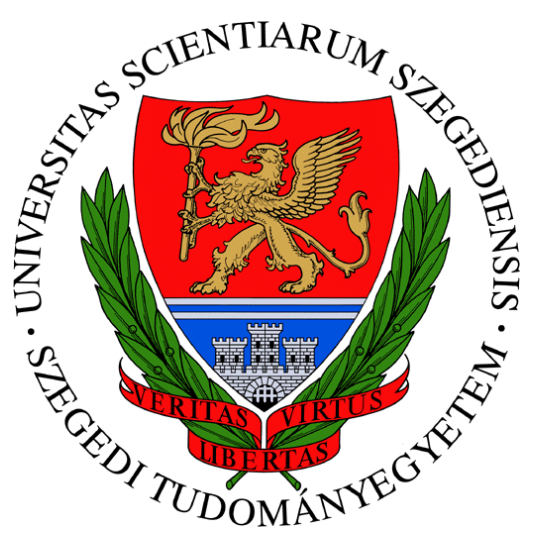

Supervisor: Dr. Miklósné Görgényi Dr. Irma Tari

University of Szeged

Department of Plant Biology 
First I offer my sincerest gratitude to my supervisor, Prof. Dr Renier van der Hoorn (University of Oxford, Department of Plant Sciences), who has supported my work partially with activity-based protein profiling of cysteine proteases and 26S proteasome in Cologne and in Oxford (in the Plant Chemetics Laboratory). I would like to express my deep gratitude to him for his patient guidance, enthusiastic encouragement and useful critiques of this research work whilst allowing me the room to work in my own way. 


\section{Contents}

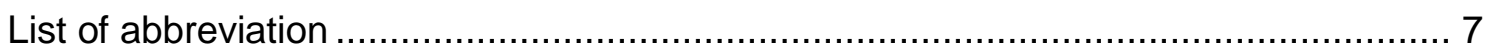

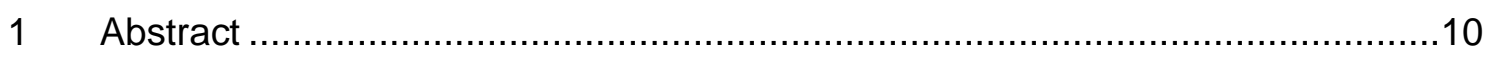

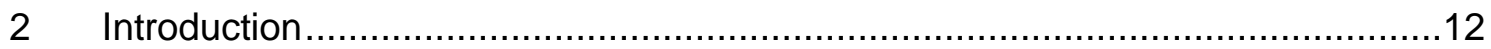

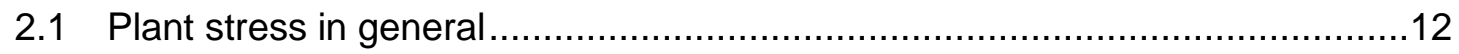

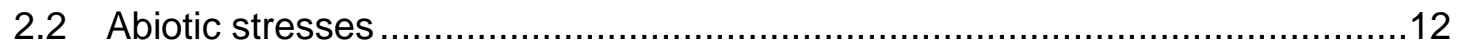

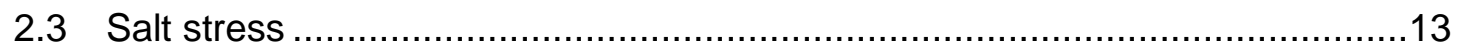

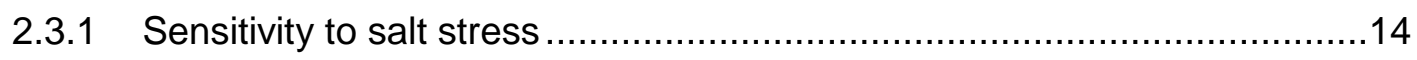

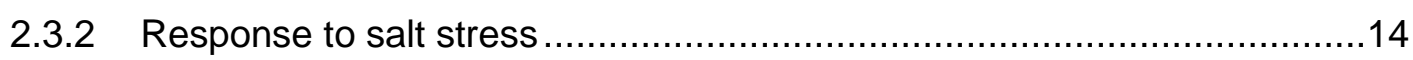

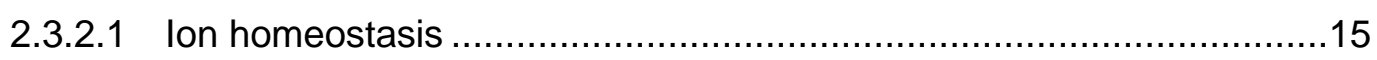

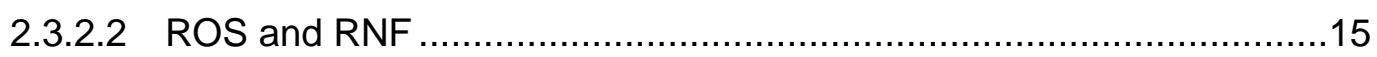

2.3.2.3 Consequences of salt stress...........................................................17

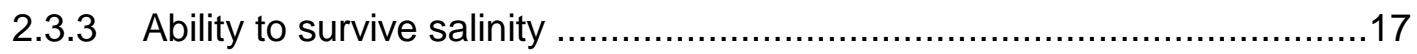

2.3.3.1 Strategies to avoid $\mathrm{Na}^{+}$toxicity …………..................................18

2.3.3.2 Polyamines and osmolytes ........................................................19

2.3.3.3 Antioxidant mechanisms..........................................................19

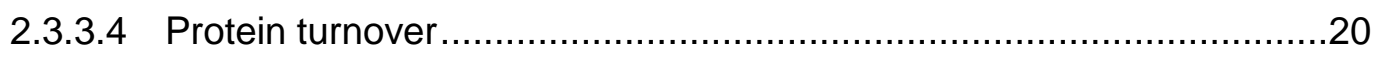

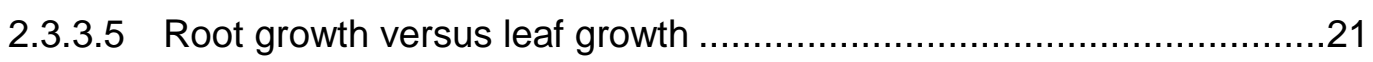

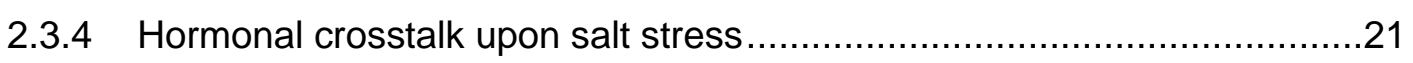

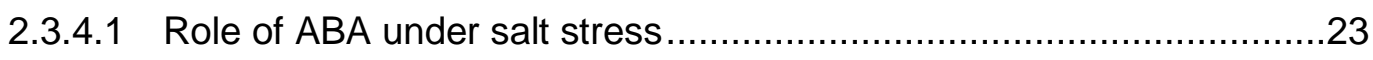

2.3.5 Salinity-induced programmed cell death (PCD) ……..........................25

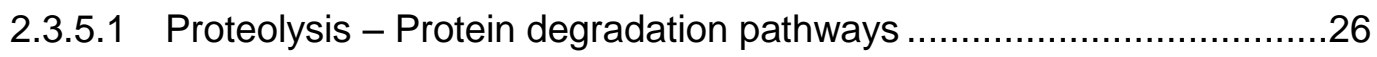

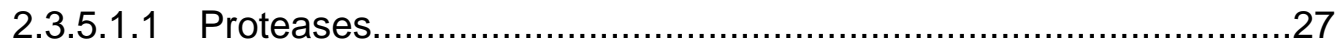

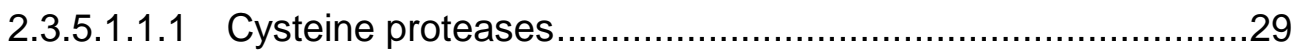

2.3.5.1.2 Ubiquitin proteasome system ………………........................

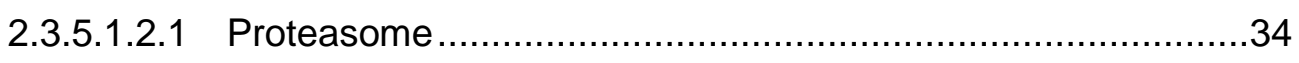

2.3.5.1.3 Activity-based protein profiling (ABPP) …………………….........

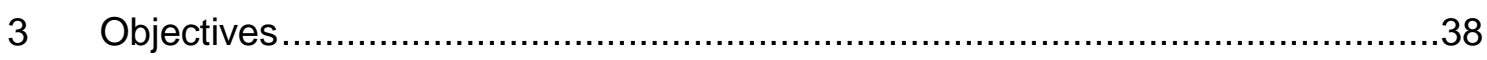

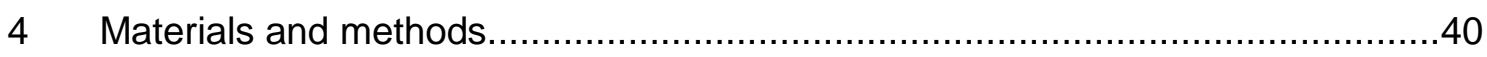

4.1 Plant Material-and Growth Conditions ......................................................

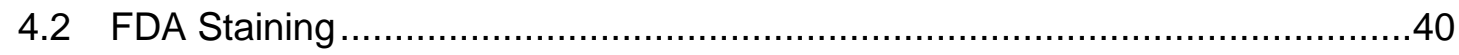

4.3 Electrolyte leakage and elemental analysis ……........................................... 40

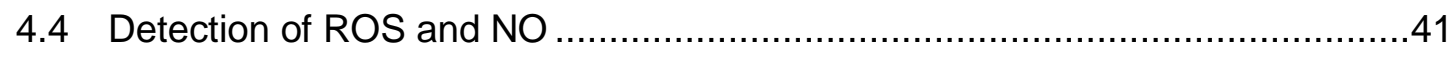

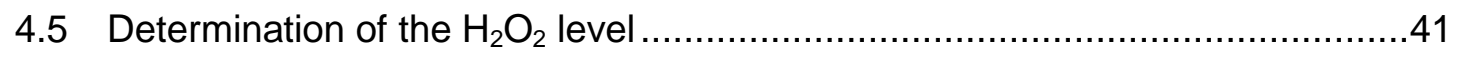

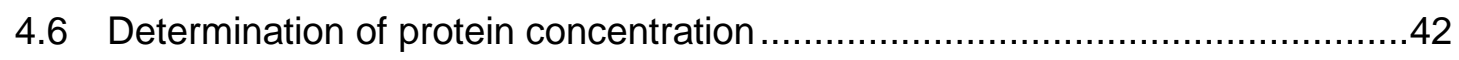

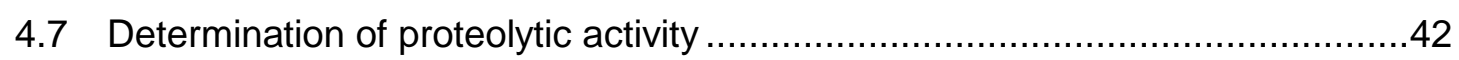




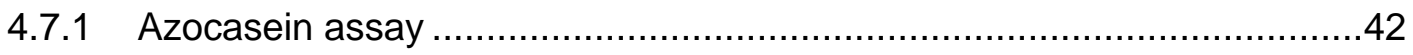

4.7.2 Gelatin-SDS PAGE ........................................................................ 42

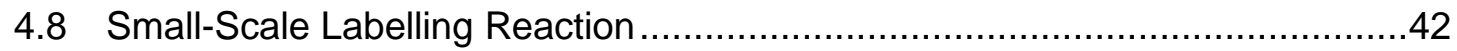

4.8.1 Sample preparation ................................................................. 42

4.8.2 Labelling of PLCPs...................................................................... 43

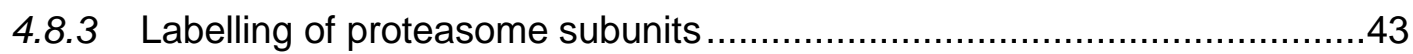

4.9 Large-Scale Labeling and Affinity Purification ...........................................43

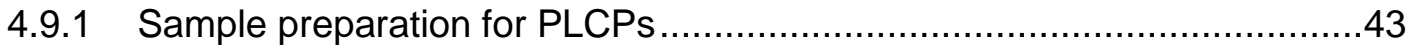

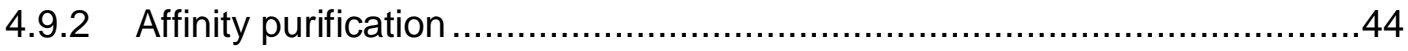

4.10 RNA extraction and expression analyses with qRT-PCR …......................44

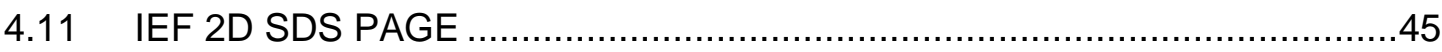

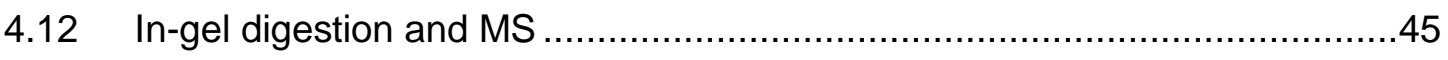

4.13 Peptide and Protein Identification .......................................................46

4.14 PNGaseF Treatment of Labeled Proteins ...............................................47

4.15 Protein Deglycosylation of Labeled Proteins .............................................47

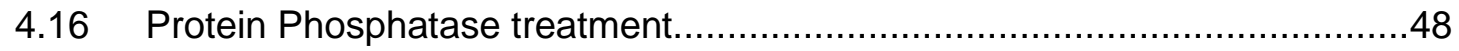

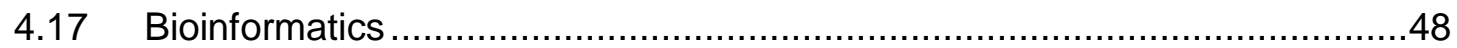

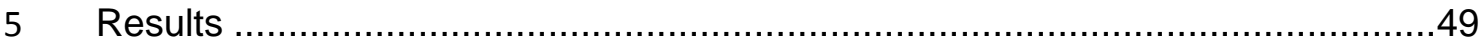

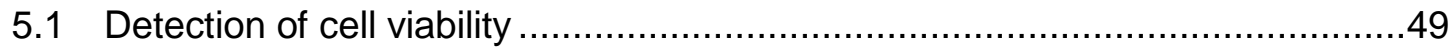

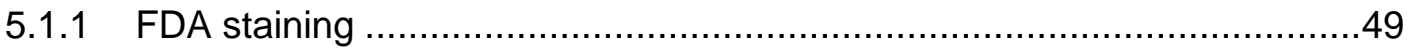

5.1.2 Electrolyte leakage and elemental analysis ......................................50

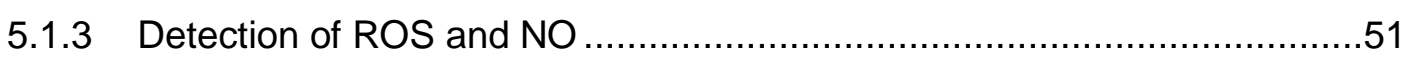

5.1.3.1 Total ROS content ............................................................... 51

5.1.3.2 $\quad \mathrm{H}_{2} \mathrm{O}_{2}$ content................................................................. 52

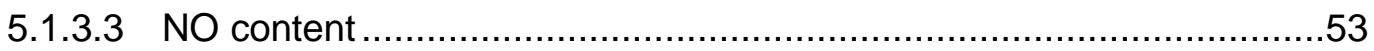

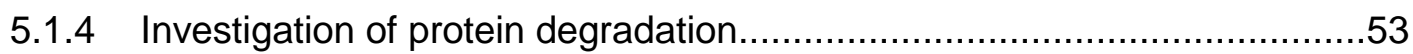

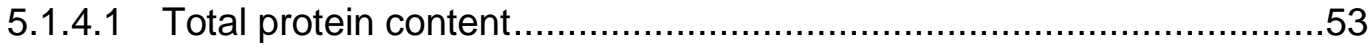

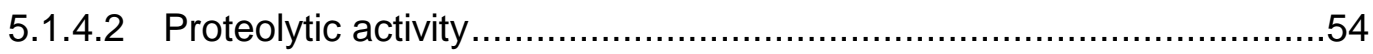

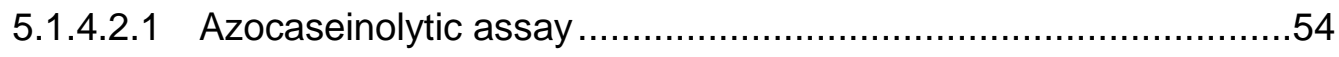

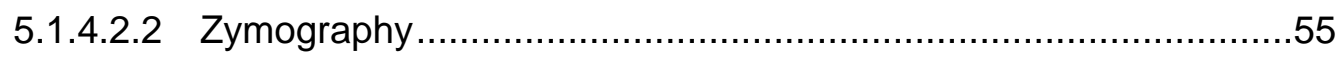

5.1.5 Investigation of Cys proteases and proteasome catalytic subunits using

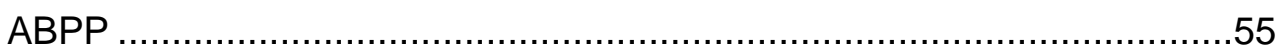

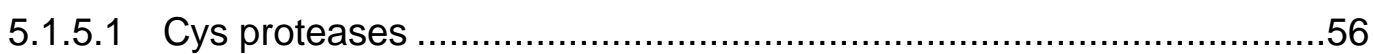

5.1.5.1.1 Papain-like cysteine proteases (PLCPs) ..................................56

5.1.5.1.2 Expression level of papain-like cysteine proteases (PLCPs) ........59

5.1.5.2 Vacuolar processing enzymes (VPEs)...........................................62

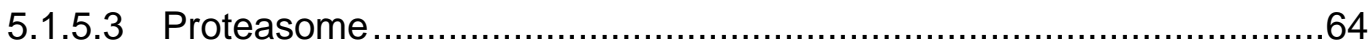


5.1.5.3.1 Phylogenetic and structural analysis of $ß$ subunits

5.1.5.3.2 Investigation of gene expression analysis of $ß$ subunits upon other stress conditions .66

5.1.5.3.3 Activity of proteasome catalytic subunits upon salt stress .68

5.1.5.3.3.1 Proteasome labeling with MV151 revealed altered proteasome activity profile .68

5.1.5.3.3.2 Confirmation of altered proteasome catalytic subunits activity labeled by MVB072 .69

5.1.5.3.4 Identification of proteasome catalytic subunits .70

5.1.5.3.4.1 Proteasome catalytic subunits separated by IEF 2D gel ........70

5.1.5.3.4.2 Alteration of $ß 5$ subunits confirmed by subunit-specific ABPs73

5.1.5.3.4.3 Investigation of potential reason of $\beta 2 \mathrm{MW}$ - and $\beta 5 \mathrm{pl} / \mathrm{MW}$ shifts .74

5.1.5.3.4.3.1 Investigation of two PTMs - phosphorylation and glycosylation .74

5.2 Investigation of the role of ABA in salt stress responses of tomato .75

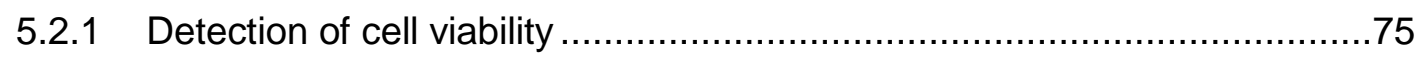

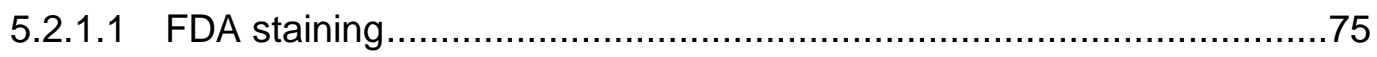

5.2.1.2 Electrolyte leakage .................................................................. 76

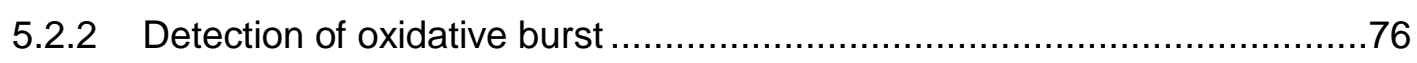

5.2.2.1 Total ROS content ...............................................................

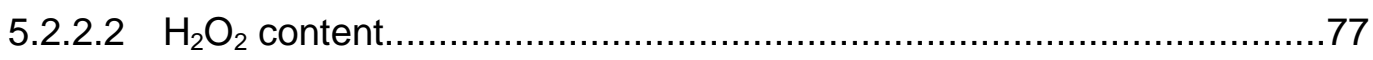

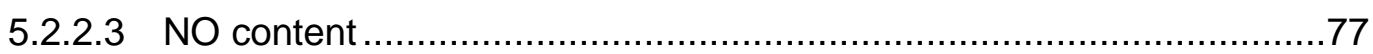

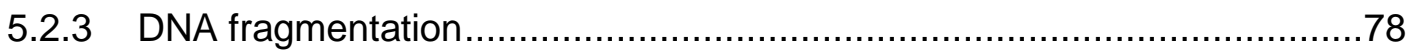

5.2.4 Investigation of protein degradation................................................. 78

5.2.4.1 Total protein content.................................................................... 78

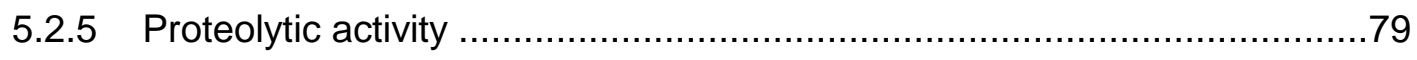

5.2.5.1 Azocaseinolytic activity ......................................................... 79

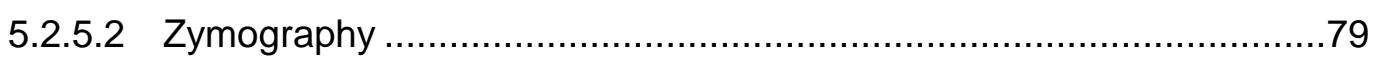

5.2.5.3 Alteration of papain-like cysteine proteases (PLCPS) in sitiens mutants

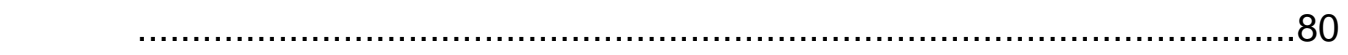

5.2.5.3.1 Expression level of papain-like cysteine proteases (PLCPs) ........81

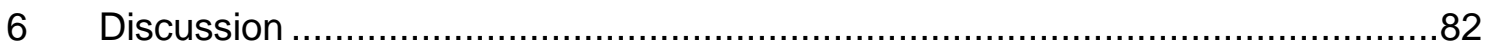

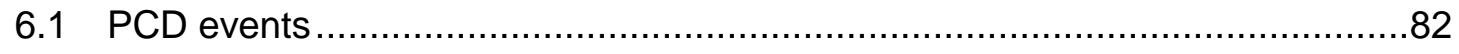

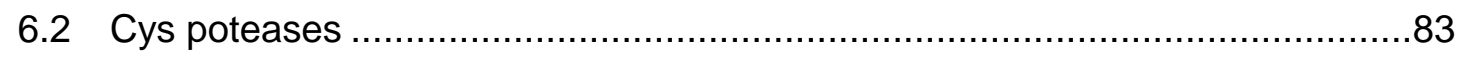

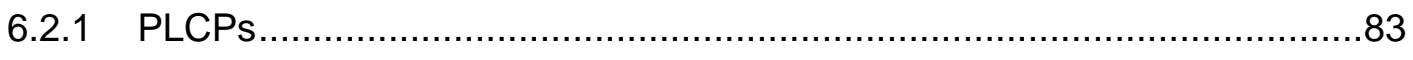

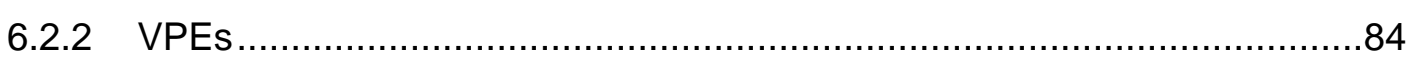




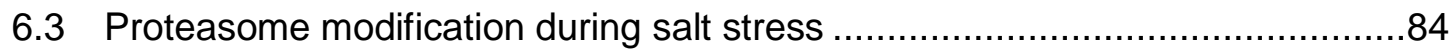

6.3.1 Post-translational regulation of the proteasome.....................................85

6.4 Investigation of the role of ABA in response to high salinity..........................86

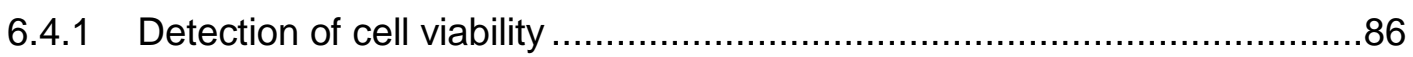

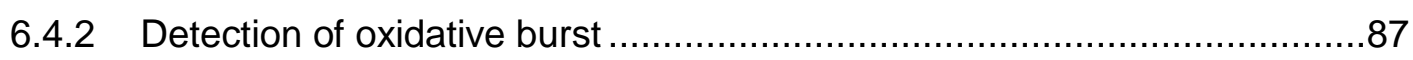

6.4.3 Investigation of protein degradation in sitiens ......................................8

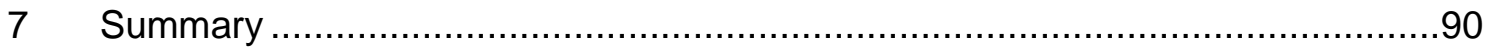

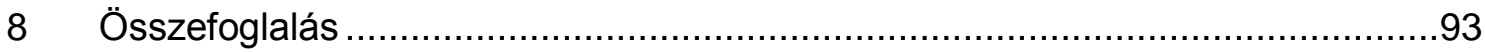

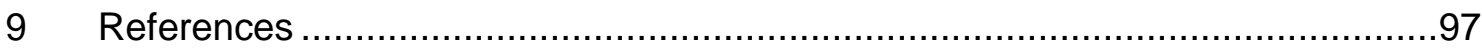

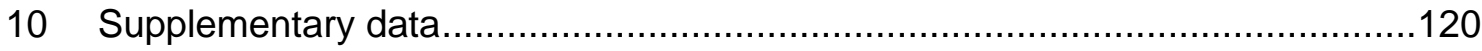

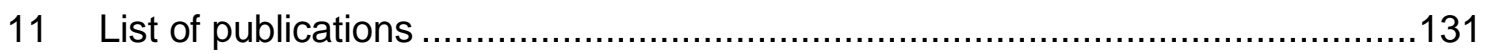

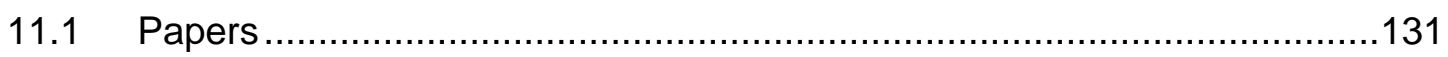

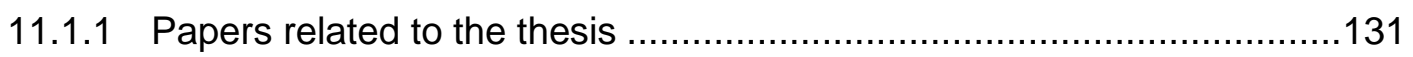

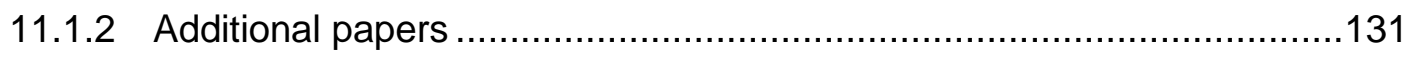

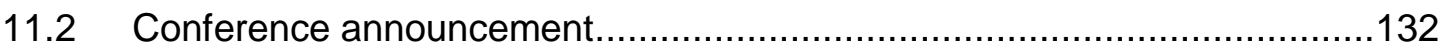

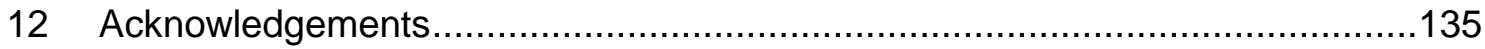

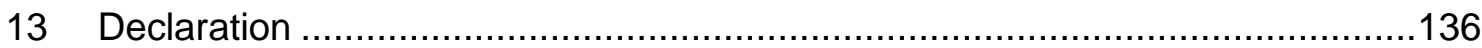




\section{List of abbreviation}

\begin{tabular}{|c|c|}
\hline ABA & absisic acid \\
\hline $\mathrm{ABI}$ & abscisic acid insensitive \\
\hline ABP & activity-based probe \\
\hline ABPP & activity-based protein profiling \\
\hline ABRE & ABA-responsive elements \\
\hline ADC & arginine decarboxylase \\
\hline ALE1 & abnormal leaf shape 1 \\
\hline APX & ascorbate peroxidase \\
\hline ASC & ascorbic acid \\
\hline BS & brassinosteroid \\
\hline BTH & benzothiadiazole \\
\hline CAT & catalase \\
\hline CcaMK & calcium/calmodulin dependent protein kinase \\
\hline CDPK & calcium dependent protein kinases \\
\hline $\mathrm{CK}$ & cytokinin \\
\hline CRE & cis-regulatory element \\
\hline Cys & cysteine \\
\hline DAF-FM DA & 4-amino-5-methylamino- 2', 7 '-difluorofluorescein diacetate \\
\hline Deg & degradation of periplasmic proteins \\
\hline DHAR & dehydroascorbate reductase \\
\hline DMSO & dimethyl sulfoxide \\
\hline DREB & dehydration-responsive element-binding \\
\hline DTT & dithiothreitol \\
\hline DUB & deubiquitination enzymes \\
\hline EC & electrical conductivity \\
\hline EL & electrolyte leakage \\
\hline ER & endoplasmic reticulum \\
\hline ERF1 & ethylene response factor 1 \\
\hline ET & ethylene \\
\hline ETI & effector-triggered immunity \\
\hline FA & formic acid \\
\hline FDA & fluorescein diacetate \\
\hline GA & gibberellin \\
\hline GPX & glutathione peroxidase \\
\hline
\end{tabular}




\begin{tabular}{|c|c|}
\hline GR & glutathione reductase \\
\hline GRAN & granulin domain \\
\hline GSH & glutathione \\
\hline $\mathrm{H}_{2} \mathrm{DCFDA}$ & $2 ', 7^{\prime}$-dichlorofluorescein diacetate \\
\hline $\mathrm{HAB}$ & hypersensitive to $\mathrm{ABA}$ \\
\hline Hsp & heat shock protein \\
\hline IAcAm & iodoacetamide \\
\hline IEF & isoelectric focusing \\
\hline IPG & immobilized pH gradient \\
\hline JA & jasmonic acid \\
\hline $\mathrm{KCl}$ & potassium chloride \\
\hline $\mathrm{KI}$ & potassium iodide \\
\hline LC-MS & liquid chromatography-mass spectrometry \\
\hline MAPK & mitogen-activated protein kinases \\
\hline MDHAR & monodehydroascorbate reductase \\
\hline MES & 2-(N-morpholino)ethane sulfonic acid \\
\hline Met & methionine \\
\hline MMP & matrix metalloproteinase \\
\hline MW & molecular weight \\
\hline NAC & NAM-ATAF-CUC \\
\hline $\mathrm{NaOAC}$ & sodium acetate \\
\hline NHA & $\mathrm{Na}^{+} / \mathrm{H}^{+}$antiporters \\
\hline $\mathrm{NHX}$ & $\mathrm{Na}^{+} / \mathrm{H}^{+}$exchanger \\
\hline NO & nitric oxide \\
\hline NSCC & non-identifiednon-selective cation channels \\
\hline PA & polyamine \\
\hline PAGE & polyacrylamide gel electrophoresis \\
\hline PAMP & pathogen-associated molecular pattern \\
\hline PBS & phosphate buffered saline \\
\hline PCD & programmed cell death \\
\hline PD & autoinhibitory prodomain \\
\hline PLCP & papain-like cysteine protease \\
\hline PM & plasma membrane \\
\hline PP2C & proteinphosphatases type-2C \\
\hline PSM & peptide spectral count \\
\hline PTI & PAMP-triggered immunity \\
\hline PTM & post-translational modification \\
\hline
\end{tabular}




$\begin{array}{ll}\text { Put } & \text { putrescine } \\ \text { PVDF } & \text { polyvinylidene difluoride } \\ \text { PYL } & \text { PYR1-like } \\ \text { PYR } & \text { pyrabactin resistance } \\ \text { RCAR } & \text { regulatory components of ABA receptors } \\ \text { RNS } & \text { reactive nitrogen species } \\ \text { ROS } & \text { reactive oxigen species } \\ \text { SA } & \text { salicylic acid } \\ \text { SAR } & \text { systemic acquired resistance } \\ \text { SDD1 } & \text { stomatal density and distribution 1 } \\ \text { SDS } & \text { sodium dodecyl sulfate } \\ \text { Sit } & \text { sitiens } \\ \text { Snf1 } & \text { sucrose-non-fermentation1 } \\ \text { SNO } & \text { S-nitrosothiol } \\ \text { SnRK } & \text { Snf1-related kinases subfamily } \\ \text { SOD } & \text { superoxide dismutase } \\ \text { SOS } & \text { salt overly sensitive } \\ \text { SP } & \text { signal peptide } \\ \text { Spd } & \text { spermidine } \\ \text { Spm } & \text { spermin } \\ \text { TCA } & \text { trichloroacetic acid } \\ \text { TF } & \text { transcritpion factor } \\ \text { TRIS } & \text { 2-amino-2-(hydroxymethyl)-1,3-propanediol } \\ \text { UP } & \text { unique peptide } \\ \text { UPS } & \text { ubiquitin proteasome system } \\ \text { VPE } & \text { vacuolar processing enzyme } \\ \text { WRKY } & \text { tyrosyl-valylalanyl-aspartyl-chloromethylketone } \\ \text { WT } & \\ \text { YVAD-CMK } & \end{array}$




\section{Abstract}

Salinity is one of the main abiotic stress factors reducing the crop productivity. Salinity affects all dicotyledonous crops and among them tomato (Solanum lycopersicum L.) is a nominated model to investigate salt stress. Tomato is moderately sensitive to salinity, thus we were able to study the effects of both sublethal- and lethal salt stress. Salt stress includes ionic-, osmotic- and oxidative stress, whereas lethal salt stress induces programmed cell death (PCD).

PCD is a well-defined, genetically controlled process. PCD has essential role in developmental processes and mediates plant responses to environmental stresses including salinity (Shabala 2009). Ordered series of events have been detected during salt stressinduced PCD. Excess of $\mathrm{Na}^{+}$results ion imbalance, reduced water potential and induces ROS burst. Disruption of ion homeostasis and ROS production collectively induces the activity of proteases and together resulting PCD.

Protein degradation is a key consequence of salt stress-induced PCD. We applied activity-based protein profiling (ABPP) to investigate the two main protein degradation pathways (protease-based and proteasome-based degradation pathways) in tomato under different salt conditions. Cys proteases are considered to participate in the regulation of PCD. In animals different stress conditions trigger the activation of caspases (Cys containing Asp-specific proteases). Although, their homologs have not been found in plant genomes, some plant proteases have caspase-like activity including Cys proteases and proteasome catalytic subunits (Han et al., 2012).

The stress proteasome in the animal kingdom facilitates faster conversion of oxidized proteins during stress conditions by incorporating different catalytic $\beta$ subunits. Plants deal with similar kinds of stresses and also carry multiple paralogous genes encoding for each of the three catalytic $\beta$ subunits. In contrast to Arabidopsis thaliana, tomato has a simplified proteasome gene set with single genes encoding each $\beta$ subunit except for two genes encoding $\beta 2$. Using proteasome activity profiling on tomato roots during salt stress we discovered a transient modification of the catalytic subunits of the proteasome coinciding with a loss of viability. This stress-induced active proteasome disappears at later time points and coincides with the need to degrade oxidized proteins during salt stress. This stress-induced proteasome may play an important role in PCD during abiotic stress.

Finally, we investigated the response of an abscisic acid (ABA)-defective, sitiens mutant of tomato exposed to sublethal- and lethal salt stress. The mutant is deficient in functional abscisic aldehyde oxidase activity catalysing the final step in ABA biosynthesis, thus the tissues accumulate about $10 \%$ ABA compared to wild type. ABA is produced under 
water-deficit conditions and under salt stress and regulates plant water balance and osmotic stress tolerance. Importantly, ABA deficiency highly increased susceptibility to salt stress in sitiens roots. Little is known about the role of ABA in protein degradation. rpn10, a mutant in regulatory particle of $26 \mathrm{~S}$ proteasome, was highly sensitive to $\mathrm{ABA}$ by the selective stabilization of the short-lived ABA-signaling protein ABI5 (abscisic acid insensitive) in Arabidopsis (Smalle et al., 2003). However, maturation process of cystein proteases was delayed and accumulation of their inactive pro-protease form was prolonged by $A B A$ in tomato endosperm (Trobacher et al., 2013).

Interestingely, activity of certain Cys proteases increased in the absence of ABA indicating that $A B A$ might promote survive via suppress proteolytic activity under high salinity. 


\section{Introduction}

\subsection{Plant stress in general}

Plants perceive and respond rapidly to environmental changes. They have evolved complex physiological, biochemical and molecular mechanisms to adapt to a variety of stresses. To maintain their internal steady-state constant throughput of energy is required. Maintenance of such a steady-state but non-equilibrium condition is called homeostasis (Hopkins and Hünner, 2004). Multiple factors can affect on homeostasis and disrupt it. These unfavourable environmental changes can be defined as environmental stress resulting in reduced yield and decreased ability of plants to develop and grow. Plant stress can be divided into two groups depending on the origin. Abiotic stress is a physical (e.g. light, temperature and water) or chemical (e.g. salinity, heavy metals) insult in contrast to biotic stress, which is caused by living organisms (e.g. bacteria, fungus and insects) (Sharma et al., 2013). Plant stress responses are dynamic and complex, they may depend on the origin, intensity, duration of the stress and on the plant tissue, organ and species affected by the stress factors (Cramer et al., 2011; Rejeb et al. 2014).

\subsection{Abiotic stresses}

Plants are mostly exposed to combination of various abiotic stressors such as salinity, drought and excessive light which reduces plant growth, development and productivity (Hoque et al., 2016). Exposure of one type of stress can often have the same effect as another stress and responses to these factors may share common molecular and biochemical signalling. Therefore it is difficult to make a difference between underlying mechanisms because there are overlaps and crosstalk between the major regulatory pathways responding to abiotic stresses (Knight and Knight 2001; Sewelam et al., 2016). Moreover, it is becoming clear that perception of a stress factor is completed by more than one sensor (Fig.1).

After the perception of primary signal by multiple primary sensors, secondary signals initiate cascade of signalling events (Sewelam et al., 2016). The early signalling events include among others alteration of cytoplasmic free $\mathrm{Ca}^{2+}$ concentration, production of secondary signalling molecules such as reactive oxygen species (ROS), reactive nitrogen forms (RNF), inositol triphosphates or abscisic acid (ABA). They activate MAPK cascade, calcium dependent protein kinases (CDPKs), calcium/calmodulin dependent protein kinases (CCaMKs) and phosphatases that in turn can phosphorylate/dephosphorylate specific 
proteins and finally they initiate activation of different transcription factors (Knight et al., 2001; Gill et al., 2016; Veram et al., 2016).These early events can be activated within seconds and minutes. Later stages of plant stress responses include activation of stress-responsive genes or the adjustment of regulatory/signalling proteins by the initiation of their synthesis or degradation and activate other defence mechanisms (e.g. antioxidant system) (Baxter et al., 2013).

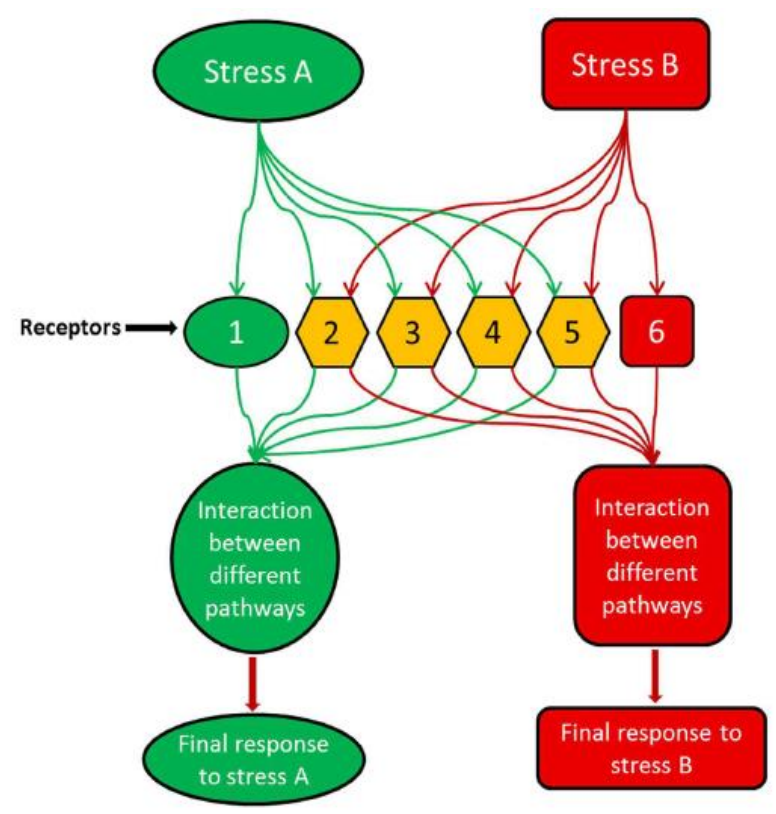

Figure 1 Different stresses or stimuli activate overlapping sensors or receptors and generate distinct responses specifically to the stress type (Sewelam et al., 2016).

\subsection{Salt stress}

High salinity is one of the major environmental stress factors globally that reduces growth and significantly limits crop productivity and it can develop either in the soil itself or by the use of irrigation water (Acosta-Motos et al., 2015; Kunert et al., 2015). A saline soil is generally defined as one in which the electrical conductivity $(E C)$ of the saturation extract in the root zone exceeds $4 \mathrm{dSm}^{-1}$ at $25{ }^{\circ} \mathrm{C}$ and has an exchangeable sodium percentage of 15 \% (Foolad et al., 2004). Saline soils contain excessive soluble salts, mainly sodium chloride $(\mathrm{NaCl})$ and sodium sulphate $\left(\mathrm{Na}_{2} \mathrm{SO}_{4}\right)$ or other neutral salts. These salts increase osmotic pressure, reduce water potential and inhibit plant growth. 20 square kilometre of land in arid and semi-arid parts of the world is lost as a consequence of salinization every day. According to the FAO database 800 million hectares of land was affected by salt in 2008. In seven years this number has increased to 1 billion hectares of salt-affected soils (FAO, 2015). Therefore, it is a global and urgent problem to improve our knowledge about salt stressinduced plant responses. 


\subsubsection{Sensitivity to salt stress}

Plant responses to salt stress depend not only on the salt concentration but also on the sensitivity of the plant species and on other environmental conditions (e.g. further stress impact, altered field conditions (slight increase in $\mathrm{pH}$, soil aggregation etc.)) (Rejeb et al. 2014; Shrivastava and Kumar 2015). There can be dramatic differences between plant species (Munns 2002). In salt sensitive plants a certain salt concentration causes strong toxicity, or even cell death, while salt tolerant plants, especially the halophytes, are growing at their optimum rate at the same salt concentration (Munns 2002; Poór et al., 2014). Halophytes are usually inhabit a wide variety of saline environments and have evolved a range of strategies to tolerate and grow in concentration of $\mathrm{NaCl}$ higher than $400 \mathrm{mM}$. Many dicotyledonous halophytes require 100-200 mM salt concentration to their optimum growth (Flowers et al., 1977; Munns and Tester 2008). Naturally, most crop plants are not able to grow in high concentration of salt (Flowers et al., 2004). The cultivated tomato, $S$. lycopersicum, is a widely-grown crop plant and its production is concentrated in warm and dry areas including the area of the Mediterranean Sea, southern and western part of US and Mexico (Flowers et al., 2004). Unfortunately, high level of salinity appeared in the soil or in irrigation water of such areas causes serious damages in tomato production therefore more attention to salinity is required in the production of tomato (Flowers et al., 2004). To maintain the productivity of tomato, breeding of new cultivars with enhanced salt tolerance is needed. Tomato is moderately sensitive to salt stress, however, several salt-tolerant accessions within tomato wild species were investigated (Foolad and Lin 1997; Singh et al., 2012). Amongst the cereals, rice proved to be the most sensitive and barley is the most tolerant species, whereas bread wheat similarly to tomato is moderately tolerant to high salinity. From halophytes, Chenopodium quinoa Willd. belonging to Chenopodiaceae, is one of the most promising grain-like crop species and Chenopodiaceae is the most dominant halophyte family for agricultural utilization (Shabala 2003). These specific traits improve external and internal $\mathrm{Na}^{+}$sequestration by the formation of trichome shape and regulation of tonoplast $\mathrm{Na}^{+} / \mathrm{H}^{+}$exchangers completed with greater cytosolic $\mathrm{K}^{+}$retention (Flowers and Colmer 2015).

\subsubsection{Response to salt stress}

Response to salt stress is a complex phenomenon and involves morphological and physiological changes. Salinity has two major effects: an early osmotic stress caused by the high salt concentration in soil solution and ionic stress caused by high salt concentration within the cytoplasm of plants cells which is expressed after a longer period (Munns and Tester, 2008). The first, osmotic phase starts when salt concentration around the roots 
reaches the threshold level (around $40 \mathrm{mM}$ ). Curiously, the shoot growth is more sensitive to salt stress than root growth. The rate of shoot growth decreases significantly which results in reduced blades of leaves and slowly emerged new leaves. Smaller leaf area would reduce the water use by the plants (Munns and Tester 2008). The second, ionic phase occurs when salt concentration increases to toxic level in the old leaves and they die. If this process is faster than the formation of new leaves, the photosynthetic capacity would decrease and the plant will not be able to produce sufficient amount of carbohydrates for maintaining the growth rate of plants (Munns and Tester 2008).

\subsubsection{Ion homeostasis}

First intracellular response to increased $\mathrm{Na}^{+}$level around the roots is the elevated cytosolic free $\mathrm{Ca}^{2+}$. $\mathrm{Na}^{+}$-induced cytosolic $\mathrm{Ca}^{2+}$ spike generated in the cytoplasm of root cells activates the SOS signal transduction cascade (Golldack et al., 2014). $\mathrm{Ca}^{2+}$, triggered by excess $\mathrm{Na}^{+}$, is perceived by a myristyolated calcium-binding protein, SOS3 (Salt OverlySensitive3) acting as a calcium-sensor (Ji et al., 2013). After binding $\mathrm{Ca}^{2+}$, SOS3 interact with active SOS2 which belongs to the SnRK3 family of protein kinases (sucrose non-fermenting-1-related protein kinase-3). SOS3-SOS2 interaction leads SOS2 to the plasma membrane to activate SOS1, which is a $\mathrm{Na}^{+} / \mathrm{H}^{+}$antiporter via phosphorylation ( $\mathrm{Ji}$ et al., 2013). SOS pathway has a crucial role in the maintenance and regulation of ion homeostasis under salt stress.

If salt stress reaches toxic level, plant loses the ability to maintain or quickly reestablish the ion imbalance to avoid both ionic and osmotic stress (Munns and Tester 2008). Disruption of the $\mathrm{Na}^{+} / \mathrm{K}^{+} / \mathrm{Ca}^{2+}$ balance can dramatically increase the production of ROS, damaging cell structures, leading to cytochrome $c$ release along with other proteins from mitochondria into the cytosol (Giannattasio et al., 2008; Shabala, 2009).

\subsubsection{ROS and RNF}

Plants exposed to stress have to face with an intensive ROS and RNF production. ROS have dual role, since generally, in low concentration they serve as signalling molecules in the cells, however, if their level is rapidly enhanced by salt stress, defined as an "oxidative burst", they become toxic. ROS molecules that mediate signalling functions are hydrogen peroxide $\left(\mathrm{H}_{2} \mathrm{O}_{2}\right)$, singlet oxygen $\left({ }^{1} \mathrm{O}_{2}\right)$, hydroxyl radical $(\cdot \mathrm{OH})$ and superoxide radical $\left(\mathrm{O}_{2}{ }^{-}\right)$ (Gadjev et al., 2006). To utilize ROS as signalling molecules their level must be maintained by a fine balance between ROS production and ROS-scavenging pathways (Baxter et al., 2013). Primarily among the ROS, $\mathrm{H}_{2} \mathrm{O}_{2}$ received more attention in the past decades as a signalling molecule. Since $\mathrm{H}_{2} \mathrm{O}_{2}$ is relatively stable compared to other ROS, this allows its 
transport through the membranes via aquaporins (homologues of tonoplast- or plasma membrane (PM) intrinsic protein) or even by diffusion to other cell compartments due to its neutral characteristic, which supports its signalling function. Increased $\mathrm{H}_{2} \mathrm{O}_{2}$ level can be perceived either by various transcription factors (TFs) such as heat shock factors or alternatively by the oxidation of certain amino acid residues that may affect phosphorylation of the protein depending on their localization (Hardin et al., 2009). Namely, methionin oxidized by $\mathrm{H}_{2} \mathrm{O}_{2}$ to methionin sulfoxide can be coupled with oxidative signals and altered protein phosphorylation. It was found that oxidation of Met residues in nitrate reductase, which is a kinase substrate can inhibit the phosphorylation of nearby Ser residues (Hardin et al., 2009).

After perception, $\mathrm{H}_{2} \mathrm{O}_{2}$ affects downstream signalling components through the activation of MAPkinases (e.g. MEK2 pathway), TFs (e.g. NAC, WRKY TFs) or miRNAs (Petrov and van Breusegem 2012). Major plant transcription factors are key players in response to salinity. Several members of AREB/ABF (ABA-responsive element binding protein/ABRE (ABA-responsive cis element)-binding factor) family have been discovered to participate in stress signalling. For instance, role of DREB/CBF (dehydration-responsive element-binding/C-repeat binding factors) was early proved in increased tolerance to salt, drought and cold stress in Arabidopsis (Kasuga et al., 1999). In addition, the Arabidopsis bZIP-type AREB/ABF, bZIP24 controls reprogramming of a broad array of salinity gene expression. NAC-type AREB/ABF TFs in tomato were responsive to multiple stress responses (Ma et al., 2013) including leaf senescence in hyperosmotic salinity and $\mathrm{H}_{2} \mathrm{O}_{2}$ signalling (Wu et al., 2012). It has been discovered that AP2 (APETALA 2) and WRKY-type TFs are dependent on NAC (Jeong et al., 2010) indicating a hub role of NAC in stress signalling. The maintenance of membrane integrity is an essential point in salt tolerance. Overexpression of AtMYB41, belongs to R2R3-MYB TFs, increased drought tolerance by modulating lipid metabolism, cell wall expansion and cuticle deposition (Golldack et al., 2014)

High level of ROS causes severe cellular damage by peroxidation and deesterification of membrane-lipids and can lead to protein degradation and cell death. Lower levels are mostly responsible for the regulation of plant stress responses (Choudhury et al., 2013).

It was reported that ROS and nitric oxid (NO) are produced concomitantly under various stresses (Sewelam et al., 2016). NO has dual role, it could be protective or toxic depending on its concentration, localization and other ROS compounds (Correa-Aragunde et al., 2015). NO can act as an antioxidant and protects cells from oxidative damages e.g. by activating antioxidant enzymes via NADPH regulation in red kidney bean roots under salinity (Liu et al., 2007). In addition, NO also mitigates ionic and osmotic stress (Poór et al., 2014) because it serves as a signal via increased $\mathrm{Na}^{+} / \mathrm{K}^{+}$ratio in the activation of $\mathrm{PM} \mathrm{Na} / \mathrm{H}^{+}$ 
antiporter, PM and vacuolar $\mathrm{H}^{+}$-ATPase and $\mathrm{H}^{+}$-pyrophosphatase (Zhang et al., 2006; Liu et al., 2007). Several studies proved the cooperation between NO and hormonal signalling. For instance, NO-mediated modulation of ion homeostasis via PM $\mathrm{H}^{+}$-ATPase activity is supported by ethylene. Additionally, NO generation is proposed for normal stomatal function and it is $\mathrm{H}_{2} \mathrm{O}_{2}$ dependent in the context of ABA-related stomatal closure under salinityinduced water deficit (Bright et al., 2006; Yu et al., 2014). NO is also supposed to activate MAPKs which may be related to stomatal closure (Zhang et al., 2007). NO reaches the maximum level in the first minutes and hours after salt exposure and NO was usually detected only in the limited time interval (Poór et al., 2014). Interestingly, NO can express its biological function via chemical reaction with highly reactive Cys residues. Most of these post-translational modifications are S-nitrosylations, the addition of an NO moiety to a reactive Cys thiols to form S-nitrosothiols (SNO) (Yu et al. 2014). Stress-induced NO contributes to SNO accumulation while salinity also increased total SNO (Camejo et al., 2013). Although, NO can induce programmed cell death (PCD) but only with the contribution of $\mathrm{H}_{2} \mathrm{O}_{2}$ (Bright et al., 2006). $\mathrm{NO}$ and S-nitrosylation are pivotal mediators of leaf cell death in rice (Lin et al., 2012). Moreover, it can react with superoxide generating toxic ONOO (Delledonne et al. 2001), which at high concentration initiates cell death (Gupta and Igamberdiev 2011; Poór et al., 2014).

\subsubsection{Consequences of salt stress}

Other typical hallmarks of plant PCD are DNA degradation and lipid peroxidation. Oxidative degradation of lipids may induce elektrolyte leakage which is related to membrane damage causing cell death (Demidchik et al., 2014). It is mainly caused by the efflux of $\mathrm{K}^{+}$ and so-called counterions $\left(\mathrm{Cl}^{-}, \mathrm{HPO}_{4}{ }^{2-}, \mathrm{NO}_{3}{ }^{-}\right.$, citrate ${ }^{3-}$, malate $\left.{ }^{2-}\right)$ that move to balance the efflux of positively charged $\mathrm{K}^{+}$. Oxidative stress induces further $\mathrm{K}^{+}$-efflux via the activation of nonselective cation channels (NSCCs), which may lead increased protease activity.

To summarize, all of the above mentioned processes, including decreased water potential, disruption of ion homeostasis, ROS burst, DNA laddering, lipid peroxidation and increased protease activity, can induce PCD upon salinity.

\subsubsection{Ability to survive salinity}

There are several defence pathways to prevent cellular dehydration and ion imbalance in the early phase of salt stress. In order to survive a saline environment plants have activate defence mechanisms i.e. to alter ion transport and compartmentation, to activate osmotic adjustment and the protein turnover, respectively. Steady state protein turnover requires high $\mathrm{K}^{+} / \mathrm{Na}^{+}$ratio because it is inhibited by $\mathrm{Na}^{+}$concentration above $100 \mathrm{mM}$ and not by $\mathrm{Cl}^{-}$ 
accumulation (Leigh and Wyn Jones 1984). Interestingly, the cytosolic enzymes of halophytes are not adapted to high salt concentrations and show the same susceptibility to $\mathrm{NaCl}$ as enzymes from glycophytes. Thus, plants respond to elevated $\mathrm{Na}^{+}$concentrations by maintaining high cytoplasmic $\mathrm{K}^{+} / \mathrm{Na}^{+}$ratio (Blumwald 2000). There are different types of plant adaptation to survive high salinity. The capacity of salt tolerance depends on the ability of salt exclusion from the cells or tolerate high salt concentration in the leaf e.g. by vacuolar sequestration of $\mathrm{Na}^{+}$(Munns and Tester 2008).

\subsubsection{Strategies to avoid $\mathrm{Na}^{+}$toxicity}

First, to avoid salt toxicity, $\mathrm{Na}^{+}$has to be removed from the cells in a nonspontaneous, energy-dependent manner. It has been well established that $\mathrm{Na}^{+}$can enter the plants through different ion channels and carryers including glutamate like receptors, cyclic nucleotide gated channels or non-identified NSCCs (Maathuis et al., 2014). Removal of $\mathrm{Na}^{+}$from cytoplasm to the apoplast can be mediated by $\mathrm{Na}^{+} / \mathrm{H}^{+}$antiporters (NHA). This is the main mechanism for $\mathrm{Na}^{+}$exclusion (Blumwald et al., 2000). SOS1 is well-characterized NHA prominently expressed in root tips and xylem parenchyma cells (Wu et al., 1996). Although such tissues complete exclusion of cytoplasmic $\mathrm{Na}^{+}$mediated by SOS1, most of the plant tissues do not show SOS1 expression and it is still not clear which antiporter is responsible for this process (Maathuis et al., 2014). Cation $/ \mathrm{H}^{+}$exchange family at the vacuolar membrane might be an alternative solution of $\mathrm{Na}^{+}$exclusion from the cytoplasm into the vacuoles, which is probably compatible with both $\mathrm{K}^{+}$and $\mathrm{Na}^{+}$(Evans et al., 2012).

Second, compartmentalisation of $\mathrm{Na}^{+}$in vacuole is a crucial point of survival and allows the plant to use $\mathrm{NaCl}$ as an osmoticum, to maintain its water potential and to prevent water loss, respectively (Blumwald et al., 2000; Maathuis et al., 2014). $\mathrm{Na}^{+} / \mathrm{H}^{+}$exchanger 1 (NHX1) is the major participant in the vacuolar cation transport. Several studies have been revealed that NHX1 has a fundamental role in salt tolerance including Arabidopsis (Apse et al., 1999), tomato (Zhang and Blumwald, 2001) and rice (Fukuda et al., 2004). However, recently it was discovered that $\mathrm{NHX} 1$ can transport both $\mathrm{K}^{+}$and $\mathrm{Na}^{+}$and it contributes probably rather maintaining of $\mathrm{K}^{+}$homeostasis than $\mathrm{Na}^{+}$compartmentalisation (Maathuis et al., 2014).

Third strategy is the long distance $\mathrm{Na}^{+}$transport meaning the translocation of $\mathrm{Na}^{+}$from root to shoot. The first two mechanisms were typical to glycophytes classified as excluders because they always force to maintain $\mathrm{Na}^{+}$and $\mathrm{Cl}^{-}$concentration below the toxic level (Munns 2002). Halophytes are able to perform exclusion strategy with higher salt stress than glycophytes (Munns and Tester 2008). For example, wheat can survive with $25 \%$ reduction of growth on $120 \mathrm{mM} \mathrm{NaCl}$ with internal $20 \mathrm{mM} \mathrm{Na}^{+}$and high $\mathrm{K}^{+}$while saltbush maintained 
normal ion homeostasis on $400 \mathrm{mM} \mathrm{NaCl}$ (Munns 2002). But the third strategy is individual for halophytes classified as includers and $\mathrm{Na}^{+}$is actively transported within the plant (Flowers et al., 1977; Volkov, 2015).

\subsubsection{Polyamines and osmolytes}

Previously, it was revealed that polyamines (PAs) (spermidine (Spd), spermin (Spm), thermospermine (tSpm) and their obligate precursor putrescine (Put)) have special importance in salt stress. Arginine decarboxylase (ADC) is the key enzyme in PA synthesis. Oat $A D C$ with stress-inducible promoter was transformed into rice. The second generation had increased Put accumulation and biomass suggesting that the accumulation of Put can improve salt tolerance (Roy and $\mathrm{Wu}, 2000$ ). The effect of PAs is achieved by nuclear DNA stabilization in eukaryotic organisms and mitochondrial and chloroplastic DNA in plants, respectively (Sairam and Tyagi 2004). PAs have pivotal role in membrane protection since they are polycationic compounds therefore they are able to interact with anionic membrane compounds reducing the possibility of aggregate formation (Schuber 1989; Poór et al., 2015). It was also revealed that Put effectively reduces lipid peroxidation and also ROS level with Spd and Spm (Papadakis and Roubelakis-Angelakis 2005; Tang and Newton 2005).

Several studies have investigated salt tolerant genotypes carrying a specific enzyme, producing more osmolytes (e.g. proline, sugars, sugar alcohols, glycine-betaine etc.) and accumulating them to protect membranes and proteins from aggregation (Kidric et al., 2014). Although the most important role of the accumulation of compatible solutes is to maintain the osmotic potential between the soil solution and cell compartments; they also protect tissues through scavenging of ROS, which is strengthened by non-enzymatic and enzymatic antioxidant systems (Poór et al., 2015).

\subsubsection{Antioxidant mechanisms}

ROS accumulation during stress greatly depends on the balance between ROS production and ROS scavenging and an imbalance leads to oxidative stress (Mittler et al., 2004). Major sources of ROS are electron transport chains of chloroplasts and mitochondria and they are directly produced in peroxisomes and glyoxisomes (Cheeseman 2007). In order to defend against oxidative burst, antioxidant machineries are able to eliminate ROS from the tissues. This antioxidant defense system can regulate the uncontrolled oxidation processes by scavenging ROS. Enzymatic antioxidants are superoxide dismutase (SOD) which catalyzes the dismutation of $\mathrm{O}_{2}{ }^{-}$and generates $\mathrm{H}_{2} \mathrm{O}_{2}$. The most important enzymes participating in $\mathrm{H}_{2} \mathrm{O}_{2}$ destruction are catalase and different peroxidases, especially ascorbate- or glutathione peroxidase (APX, GPX). APX together with glutathione reductase 
(GR) are essential enzymes in ASH-GSH cycle which can effectively scavenge $\mathrm{H}_{2} \mathrm{O}_{2}$. Basically, Fe SODs are located in the chloroplast, Mn-SOD is localized in mitochondria and peroxisomes, and CuZn-SOD can be found on the external, "stromal" membrane surface of chloroplast, in the cytosol and possibly in the extracellular space (Gill and Tuteja 2010). Components of ASH-GSH cycle have been shown to be present in cytosol, mitochondria, and peroxisomes as well as in the chloroplast (Foyer and Noctor 2011).

The other essential scavengers are non-enzymatic antioxidants such as ascorbic acid (ASC), glutathione (GSH), tocopherol, phenolic compounds, alkaloids and flavonoids (Fig.2; Gill and Tuteja 2000).

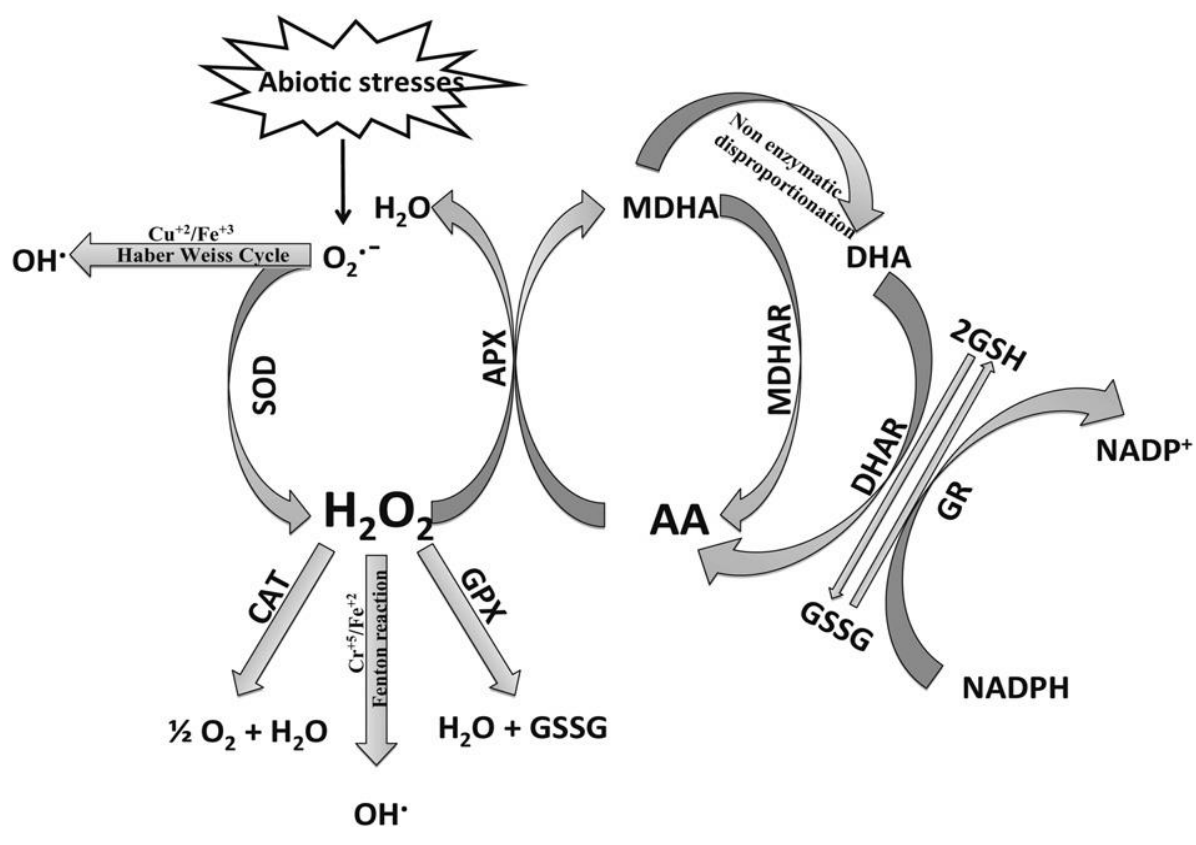

Figure 2 ROS and antioxidants defense mechanism (superoxide dismutase, SOD; catalase, CAT; glutathione peroxidase, GPX; ascorbate peroxidase, APX; monodehydroascorbate reductase, MDHAR; dehydroascorbate reductase, DHAR; glutathione reductase, GR; monodehydroascorbate, MDHA; ascorbic acid, AA; glutathione, GSH; oxidized glutathione, GSSG) (Gill and Tuteja et al., 2000).

\subsubsection{Protein turnover}

Denaturing condition is a serious threat to proteins because they might loose their active form and turn to their inactive form. Afterwards they must undergo regulated protein degradation by $20 \mathrm{~S}$ or $26 \mathrm{~S}$ proteasomes or by proteases and replaced by active form to be able to recover and establish the normal homeostatic environment (Vaseva et al., 2012). Controlled protein turnover is supported by chaperones and especially Hsp70 family is engaged in refolding misfolded and aggregated proteins, facilitating proteolytic degradation of unstable proteins by targeting them to the ubiquitin-proteasome system (UPS) and controlling the activity of regulatory proteins (Vaseva et al., 2012). Furthermore, salt-induced 
water deficit affects the expression and post-translational modification (PTM) of proteins, especially of those which are involved in avoiding stress, in repairing damage and in protecting cell homeostasis (Vaseva et al., 2012).

\subsubsection{Root growth versus leaf growth}

Interestingly, there are differences between recoveries of different organs. Root growth recovered remarkably better compared to leaf growth (Hsiao and $\mathrm{Xu} 2000$ ), since $\mathrm{Na}^{+}$ concentration, in newly-developing cells, is low and below the toxic level (Jeschke 1984; Jeschke et al., 1986) which can reduce the speed of salt accumulation overall. It is supported by the observation in cashew plants that organ responses were much more pronounced in the leaf than in the root focused on imbalance of $\mathrm{K}^{+}$and nitrogen metabolism and enhanced proteolytic activity. Nitrogen imbalance in the leaves is presumably caused by the increased proteolysis and reduced protein synthesis (Silveira et al., 2003; Shabala 2009, Demidchik et al. 2010). The root is the primary organ recognizing salt stress and initiating signalling pathways. Additionally, a few studies have described PCD in the roots upon abiotic stress. Mild salinity can also induce PCD in root tips as a defensive developmental response to maintain the integrity of the root system (Hasegawa and Bressan, 2000; Huh et al., 2002; Gémes et al., 2011). There is also a possibility that ROS have a role in systemic signalling from roots to leaves, allowing leaves to activate their defense mechanisms or to initiate biosynthesis of several hormones e.g. ethylene and abscisic acid for better protection against salt stress.

By contrast, lethal salt stress leads to elimination of the susceptible root system and plants can sustain this by creating new roots (Huh et al., 2002; Bagniewska-Zadworna et al., 2016). However, when lethal salt exposure is prolonged, it leads to death not only at the cellular level but also at the level of tissues or organs (Bagniewska-Zadworna et al., 2016).

\subsubsection{Hormonal crosstalk upon salt stress}

Plant hormones are central integrators of the growth and development and they are able to control the interaction between plants and environments, including plant responses to salt stress. Auxin, gibberellin (GA), cytokinin (CK) and ethylene (ET) are hormones that are predominantly defined as regulating growth and development, while ABA, salicylic acid (SA), jasmonates (JA) and brassinosteroids (BS) are traditionally involved in the response to abiotic and biotic stresses. However, recent studies have provided substantial evidence for the role of $A B A, S A, J A$ and $E T$ with auxins, GAs and CKs in regulating plant defense response in salt stress besides their general issues depending on their ratio (Berkowitz et al., 2016; Deb et al., 2016; Verma et al., 2016). Besides senesce promoting hormones (ABA and 
ET), it was demonstrated that CKs can be important inhibitors of leaf senescence, a special type of PCD, since senescence is delayed after exogenous application or overproduction of CKs in transgenic plants (Rivero et al., 2007; Havlova et al., 2008). However, the CK content is really low in the salinized leaves that could contribute to the senescence under abiotic stress and the decreased transport from the roots could be responsible for the decrease of CKs in the leaves (Ghanem et al., 2008).

Previously, we investigated SA- and ET signalling in stress responses. Salicylic acid, a phenolic compound, plays an important role in the defense response of plants to abiotic and biotic stressors (Hayat et al., 2010) by controlling gene expression, such as the expression of the cysteine protease gene (SAG12) or the PR1a gene encoding a protein with antifungal activity (Lu et al., 2013; Morris et al., 2000). High $\left(10^{-3}-10^{-2} \mathrm{M}\right)$ exogenous SA treatment can induce cell death by various signalling pathways, including ROS. Increased activity of cysteine proteases was a consequence of SA-induced ROS accumulation (Poór et al., 2013). For instance, LeMCA1 and yVPE genes were up-regulated during PCD and SA treatments (Hoeberichts et al., 2003; Yamada et al., 2004, Kovács et al., 2016). However, the sublethal $\left(10^{-4}-10^{-7} \mathrm{M}\right)$ concentrations of SA could generate pre-adaptation responses which led to salinity tolerance. Moreover, it could improve acclimation to high salinity by enhancing the net photosynthetic rate in a salt-tolerant wheat genotype (Arfan et al., 2007) or in tomato (Poór et al., 2011) and by stimulating ABA and polyamine accumulation (Szepesi et al., 2009).

ET is a gaseous plant stress-hormone and indispensable for tolerance to salinity (Tao et al., 2015). Salinity obviously induces ET production and the synthesis of its precursor, ACC in several plant species both in leaves and roots (Morgan et al., 1997). Both ET and JA are related to stress responses and involved in the signalling pathway controlling the progression of PCD triggered by ROS. For instance, under salt stress ET signalling is necessary for ROS production in tomato cells, however, SA-induced ROS production was independent from ET (Poór et al., 2012; Poór et al., 2013). Although ET and JA have opposite function in ROS-triggered plant cell death, cooperatively regulating a set of defense responses against biotic and abiotic stresses (McGrath et al., 2005). Under salt stress, ERF1 (ethylene response factor 1 ) is induced by $E T, J A$ and $A B A$ in tomato, supporting the idea that several genes might act as a nodal point between different hormonal signalling pathways responding to salt stress (Zhang et al., 2004; Miller et al., 2010; Ellouzi et al., 2014). ABA, JA and ET can interact positively or negatively through DREB (dehydration responsive element binding protein) transcription factor depending on the stress conditions, whether they promote or impede stress responses. ABA is known to be antagonistic to SA and suppresses disease resistance but promotes abiotic stress tolerance (Deb et al., 2016). Furthermore, 
ABA delayed both of the ET-induced and GA-promoted cell death in rice (Steffens and Sauter 2005).

This complex hormone signalling response to different stress conditions may be controlled by common transcription regulators (Deb et al., 2016). Control of hormon singalling-related gene expression is brought about by CREs (cis-regulatory elements), located in promoter regions of the target genes. Investigation of hormone biosynthesisassociated gene promoters clarifies a lot of questions. For instance, CK response elements and $A B A$ response element are enriched in promoters of BR biosynthesis associated genes. $\mathrm{BR}$ response element is located in promoters of $\mathrm{CK}$ biosynthesis associated genes. Therefore, CK and ABA both may interact directly with BR hormon biosynthesis loci likewise BR may also interact directly with CK hormon biosynthesis loci (Deb et al., 2016).

The present study would focus only on the role of ABA in salt-induced PCD.

\subsubsection{Role of ABA under salt stress}

The phytohormone, ABA plays vital role in alleviating salt stress in different ways (Javid et al., 2011; Soon et al., 2012). ABA is produced under water-deficit conditions and it regulates plant water balance and osmotic stress tolerance accompanied by a major change in gene expression and physiological responses (Zhu 2002; Raghavendra et al., 2010). In order to study ABA-dependent transcriptional regulation, one solution is to analyse cisregulatory elements in the promoter regions of target genes (Bitrián et al., 2012). For instance, three PA biosynthesis genes ( $A D C 2, S P D S 1$ and SPMS) were highly up-regulated upon drought stress and the analysis of ABA-deficient (aba2-3) and ABA-insensitive (abi1-1) mutants revealed clear evidence of $A B A$ regulation. ABRE- (ABA-responsive elements) related motifs were also found in their promoters (Alcazar et al., 2006).

ABA signalling is starting to be more clarified with ongoing efforts to highlighted remaining parts. The main core of $A B A$ signalling consists of the receptors (e.g. PYR/PYL/RCAR (PYLs)), of the positive- (e.g. Snf1 (Sucrose-non-fermentation 1)-related kinases subfamily 2 (SnRK2)) and the negative regulators (e.g. protein phosphatases type2C (PP2C)) and of the downstream substrates to regulate long- (gene expression), or shortterm (stomatal closure) ABA effects (Zhang et al., 2015). ABA is bound and sensed by nucleocytoplasmic RCAR1/PYR1/PYL receptor (Fig.3; Shen et al., 2006; Pandey et al., 2009; Park et al., 2009; Zhang et al., 2015). SnRK2 is inactivated by PP2Cs e.g. ABI1, ABI2 (abscisic acid insensitive) and HAB1 (hypersensitive to $A B A$ ), a negative regulator phosphatase of $A B A$ signalling, through direct interaction and dephosphorylation of a key serine residue in the kinase activation loop (Yoshida et al., 2006; Boudsocq et al., 2007). Upon ABA binding, dimeric PYLs undergo conformational changes leading inhibition of 
PP2Cs (Park et al., 2009). Then, the activated SnRK2 targets ABRE binding factors (such as bZIP) to regulate gene expression in the nucleus and the cation channel (SLAC1) and potassium channel (KAT1) to cause stomatal closure (Fig.3; Zhang et al., 2015). Interestingely, RCARs expression level is decreased but PP2Cs are up-regulated under stress condition leading to $A B A$ desensitisation which might cause strongly increased $A B A$ accumulation for adjustment of ABA signalling (Raghavendra et al., 2010).

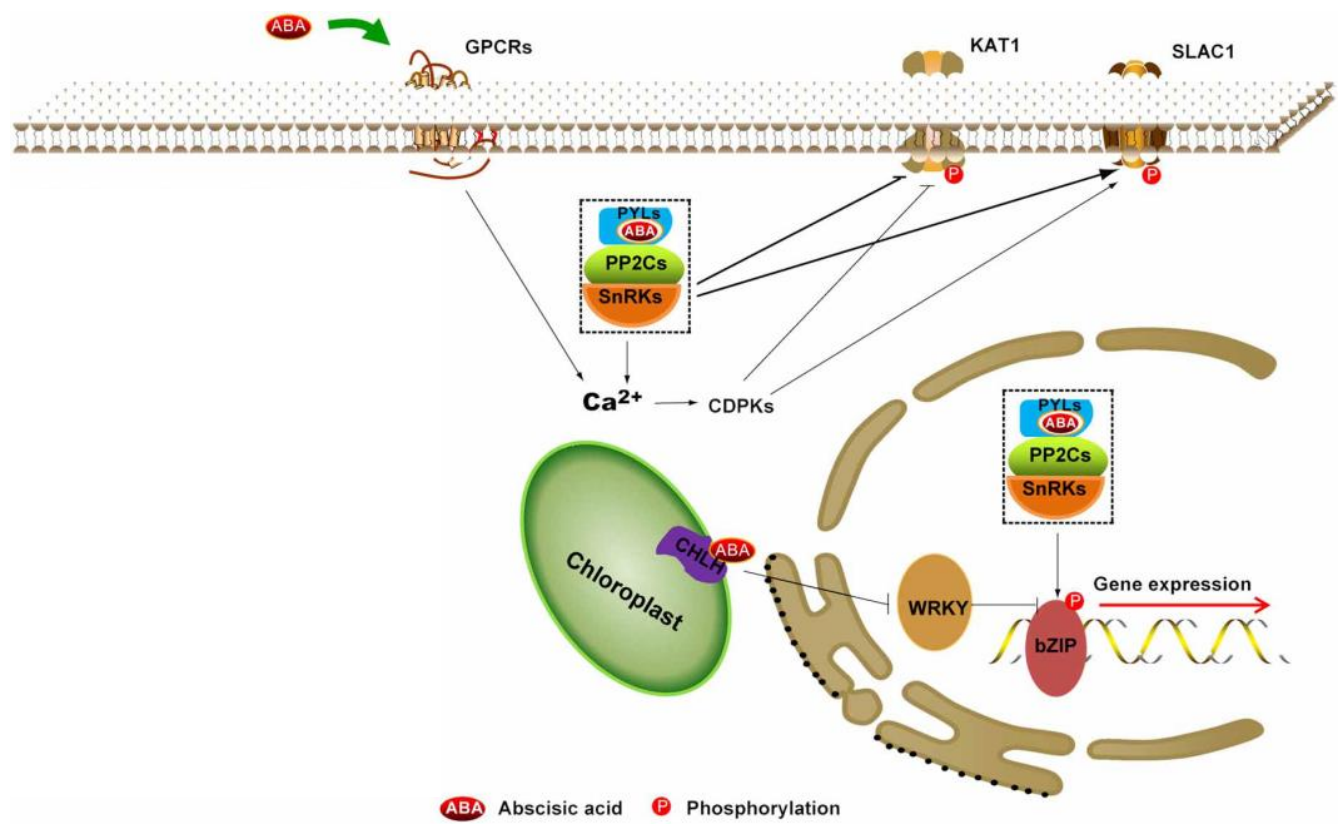

Figure 3 Summary of ABA signalling. In the absence of ABA, negative regulators, such as PP2Cs inactivate the positive regulators of ABA-signalling, SnRKs through physical interaction and dephosphorylation. In the presence of ABA, ABA receptors (GPCRs, PYLs, $\mathrm{CHLH}$ ) bind $\mathrm{ABA}$ and inactivate PP2Cs. Thus, SnRKs are activated through autophosphorylation and initiate ABA signalling. (ABA, abscisic acid; GPCRs, G proteincoupled receptors; PYLs, PYR1 (Pyrabactin Resistance 1)-related homologous of Arabidopsis; PP2C, protein phosphatases type-2C; SnRKs, Snf1 (Sucrose-non-fermentation 1)-related kinases subfamily 2; CDPKs, cyclin-dependent protein kinases; KAT1, potassium channel in Arabidopsis thaliana 1; SLAC1, slow anion channel-associated 1 (Zhang et al., 2015).

Salt stress-triggered $A B A$ accumulation was more significant in the roots than in the leaf tissues in maize (Jia et al. 2002) and tomato (Szepesi et al. 2009). Salinity-induced ABA in the roots was transported to the shoots causing stomatal closure by active (ABAmediated), e.g. ABA-triggered changes of ion fluxes in guard cells, and/or passive (hydraulicmediated) mechanisms, respectively (Raghavendra et al., 2010). Furthermore, ABA can be produced in leaf vascular parenchyma cells and after entering xylem sap it may diffuse out to the leaf apopoplast restricting cellular growth and leaf expansion (Fricke et al., 2004; Cabot et al., 2009; Dodd 2013; Kholi et al., 2013). Therefore, salinity induced ABA can directly affect photosynthesis due to the decreased $\mathrm{CO}_{2}$ availability via stomatal closure, and/or from 
alteration of carbon metabolism ( $\mathrm{Li}$ et al., 2015). These ABA mediated effects in stressed plants are well defined, but little is known about the direct role of ABA on photosynthesis, especially on the activity of photosytem II (PSII) and its cooperation with PSI under salt stress. Short- and long-term ABA treatments had no effects on PSIl photochemistry and carboxylation efficiency but it decreased $\mathrm{CO}_{2}$ assimilation and stomatal conductance in maize (Jia and Lu 2003). However, $10 \mu \mathrm{M}$ of ABA did not modify the water potential in citrus under lethal salt stress but improved the photosynthetic rate and stomatal conductance and decreased the sublehtal salt stress-induced $\mathrm{Cl}^{-}$accumulation (Gomez-Cadenas et al., 2003).

Moreover little is known about the relation between ABA and cysteine proteases which can mediate the proteolysis of photosynthetic proteins, such as RUBISCO. However, molecular and biochemical data confirmed that ABA suppressed GA-induced PCD inhibition via suppression of cysteine protease, SICysEP (Trobacher et al., 2013).

\subsubsection{Salinity-induced programmed cell death (PCD)}

PCD is a well-defined, genetically controlled process and it plays a critical role in response to changing environments. Some typical PCD events have been detected during salt stress-induced PCD, which are common with animal cell death. Oxidative burst, DNA fragmentation and nuclear chromatin condensation can also occur during salt stress-induced PCD in plants (Andronis et al., 2010). If salt stress is persistent, PCD is induced (Poór et al., 2014).

DNA laddering was visible as soon as one hour after $\mathrm{NaCl}$ exposure. Importantly, DNA laddering did not occurr in sorbitol-treated cells, which means that only ionic stress and not osmotic stress activates endonucleases resulting in PCD (Huh et al., 2002; Affenzeller et al., 2009).

High electrolyte leakage (EL) is also a typical hallmark of PCD in intact plant cells and it is widely used to reveal plant stress tolerance (Levitt 1972; Whitlow et al., 1992; Demidchik et al., 2014). It is mainly caused by the efflux of $\mathrm{K}^{+}$and persists from the first minutes of stress exposure to several hours. As a result of salt stress, $\mathrm{K}^{+}$content can dramatically and irreversibly fall in the roots. This reaction is accompanied by $\mathrm{Ca}^{2+}$ and $\mathrm{H}^{+}$efflux, by $\mathrm{ROS}$ generation and protease activation (Demidchik et al., 2014). $\mathrm{NaCl}$-induced $\mathrm{K}^{+}$release through the outward-rectifying $\mathrm{K}^{+}$channels (GORK and SKOR) has been demonstrated in Arabidopsis root epidermis and leaf mesophyll cells (Shabala et al., 2006; Demidchik et al., 2010) as well as in barley root cells (Chen et al., 2007; Zepeda-Jazo et al., 2008).

Interestingly, $\mathrm{Ca}^{2+}$ elevation, $\mathrm{ROS}$ generation, reduction of cytoplasmic $\mathrm{K}^{+} / \mathrm{Na}^{+}$ratio and activation of proteases together establish a clear system resulting in PCD. It was demonstrated that salt stress-induced $\mathrm{Ca}^{2+}$ elevation activates $\mathrm{ROS}$ production via activating 
PM-localized NADPH oxidase as a positive feedback mechanism (Shabala 2009). Furthermore, $\mathrm{OH}^{*}$ activates $\mathrm{K}^{+}$efflux channels in intact root epidermis of wild-type tomato upon salt stress (Demidchik et al., 2010), in pea root epidermis (Zepeda-Jazo et al., 2011) and in barley root cells (Velarde-Buendía et al., 2012). Finally, in animals, PCD-specific hydrolytic enzymes are blocked by $\mathrm{K}^{+}$. To support this hypothesis during plant cell death it was discovered that both $\mathrm{K}^{+}$channel blockers and the lack of a functional $\mathrm{K}^{+}$efflux channel (GORK) inhibit the $\mathrm{NaCl}$ - and oxidative stress-induced activation of PCD proteases and endonucleases (Fig.4).

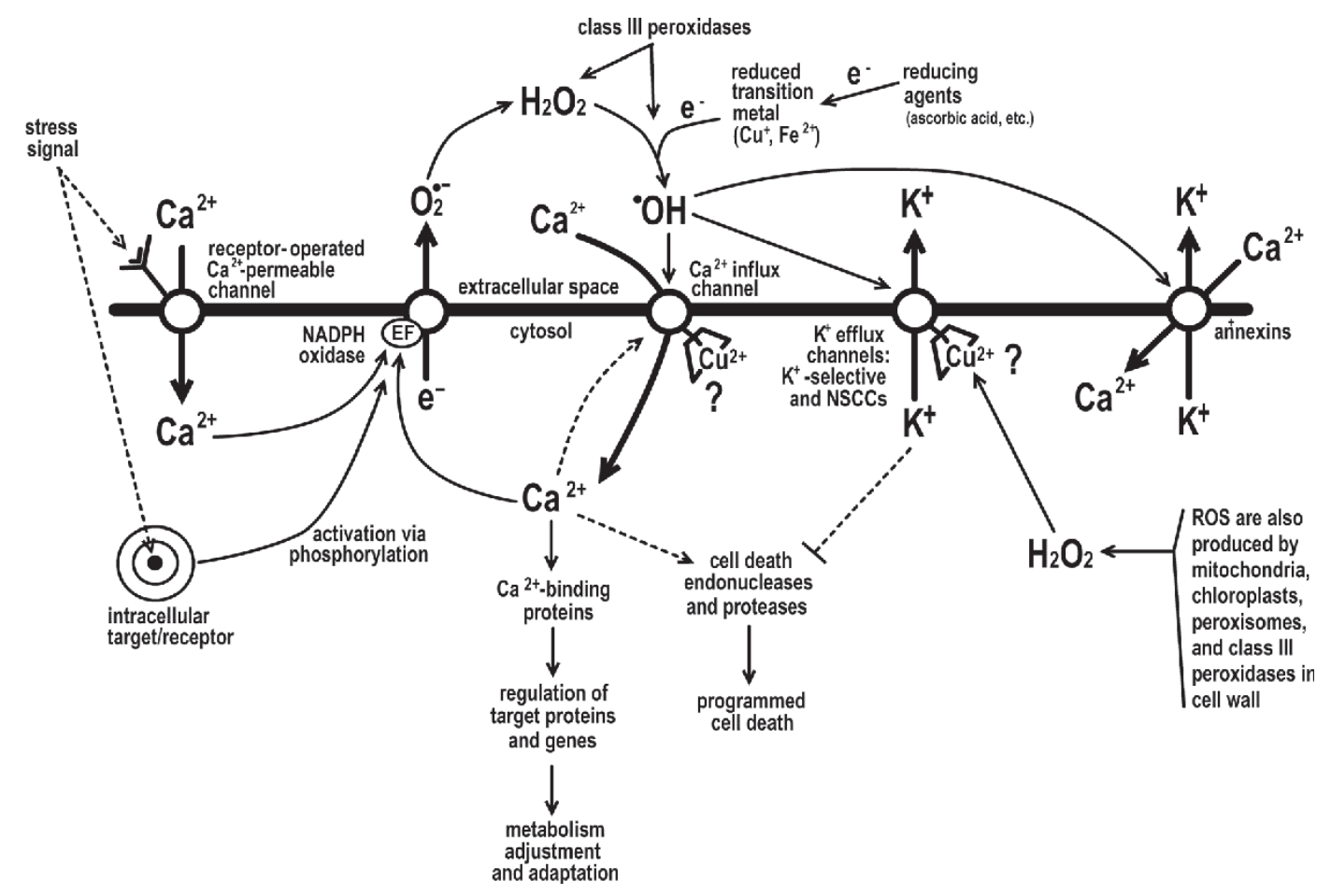

Figure 4 The proposed model of the hypothetical mechanism of ion specific signalling at the PM of plant cells (Demidchik et al., 2014).

PCD often includes protein degradation, mediated by protease- or proteasome-based degradation pathways (Gadjev et al., 2008). Processing cascades facilitate proteases to reach their mature form and degrade misfolded and damaged proteins. They consequently degrade the cytosolic components during cell death (Kinoshita et al., 1999; Yamada et al., 2005). PCD might be regulated by a specific subset of proteases that change the abundance of signal molecules modulating stress signaling (Tornero et al., 1996; Coffeen et al., 2004).

\subsubsection{Proteolysis - Protein degradation pathways}

Degradation of a protein occurs by proteolysis ruled by hydrolytic enzymes called proteases. There are two major systems for intracellular protein degradation: (a) protease pathway or (b) proteasome-based degradation pathway (Turk et al., 2012). 
There are several major roles of proteolysis. First, it re-localizes nutrients from old or stressed organs to newly growing or sink organs, e.g. during senescence (Diaz-Mendoza et al., 2016). Nutrient recycling, especially, that of nitrogen has an essential role in leaf senescence that associate not only with reprogramming of expression of thousands of genes but also with the maintenance of basic metabolic activities which are essential to process high molecular weight (MW) molecules and to mobilize the hydrolyzed products to the phloem (Diaz-Mendoza et al., 2016). Second, in woody tissues organelles of tracheary elements are degraded after vacuole disruption very rapidly by the activation of cysteine proteases and proteasome in contrast to leaf PCD where the nucleus and the vacuole degrade after complete degeneration of chloroplast (Moreau et al., 2005). Third, selective destruction of misfolded or damaged proteins is an essential mechanism to ensure the quality of intracellular proteins and to protect cells from potentially toxic proteins in order to maintain cell viability (Goldberg 2003).

The first evidence that the cells are able to degrade abnormally folded proteins was first revealed in the 1970's years (Goldberg 1972). Afterwards, protein degradation was intensively studied in the past decades and nowadays powerful tools are available to broaden our knowledge, especially under high salinity since salt stress-induced protein degradation is still less explored.

\subsection{Proteases}

Proteases are key regulators controlling different developmental processes and response to diverse environmental stimuli by maintaining strict protein quality control and degrading specific sets of proteins. However, they are involved in most cellular processes, still very little is known about their substrate specificity, physiological roles or cellular location of many of putative proteases (Garzia-Lorenzo 2007). Proteases catalyze the hydrolysis of peptide bonds that can be internal- (endopeptidases) or external (exopeptidases). Exopeptidases can either cleave at the C-terminal (carboxipeptidases) or N-terminal (aminopeptidases) of proteins. Based on their active site residues they are categorized into four classes: cysteine-, serine-, metallo-, and aspartic proteases (van der Hoorn 2008). According to their common evolutionary origins protease classes are subdivided into several families and clans. They have natural and synthetic inhibitors; these data are collected in MEROPS database (Hauske et al., 2008; van der Hoorn 2008).

Proteases are usually synthesized as a pre-protein and contain an autoinhibitory domain that has to be removed during the activation of the enzyme (van der Hoorn et al., 2004). Activity of proteases are strictly regulated in a number of ways, most importantly by protease inhibitors, by maturation processes that could be autocatalytic lactivation like in the 
case of vacuolar processing enzymes (VPE) (Misas-Villamil et al., 2013) or allosteric regulation by small molecules (Hauske et al., 2008). Their regulation is really important because their proteolytic activity is potentially harmful for unspecific substrates and they play critical roles in a broad range of biological processes essential for the plant's life including hormone signalling, embryogenesis, photomorphogenesis, flower development and defense responses etc. (Habib and Fazili 2007).

Serine protease family is the largest class of proteases in plant kingdom and is divided into 14 subfamilies. From biochemical point of view they are well described, however, biological functions were discovered only for few members of the subfamilies - for subtilases, carboxypeptidases and plastid-localized members (van der Hoorn 2008). It seems that they have crucial role not only in developmental processes but also in stress responses. For instance, two subtilases, SDD1 (Stomatal density and distribution 1) is involved in the regulation of the stomata development (Berger and Altmann 2000). The other serine protease, ALE1 (abnormal leaf shape 1) has a major role in appropriate cuticle development during embryogenesis (Tanaka et al., 2001). EP3, a subtilisin-like protease of S8A serine protease family, is remarkably increased in dark-induced and naturally senescing wheat leaves (Wang et al., 2013). Deg proteases, ATP-independent serine hydrolases are localized mainly in chloroplast and probably in mitochondria. It appeared that chloroplastic Deg proteases have vital role in the degradation of photodamaged photosynthetic proteins. Especially, lumenal Deg1, Deg5 and Deg8 have pivotal importance in the repair of damaged PSIl by removal of photodamaged D1 proteins (Schuhmann and Adamska 2012). Furthermore, increased activity of serine hydrolases, including Hsr203 and P69B in the apoplast precedes tissue collapse during hypersensitive response (HR) (Sueldo et al., 2014) or P69 is required for resistance of tomato against Cladosporium fulvum (Song et al., 2009).

Metalloproteases are involved in nodulation, plastid differentiation, thermotolerance, regulation of root and shoot meristem size, sensitivity to auxin conjugates and meiosis (van der Hoorn 2008). It has been revealed that tomato $L 2$ encodes an ortholog of Arabidopsis EGY1, which is a membrane-bound, chloroplast-targeted protease and a member of zincdependent M50 metalloprotease family, required for normal plastid development since it mediates chlorophyll accumulation (Chen et al., 2005). These evidences suggest that L2/EGY1 homologs may have a role in mediating chloroplast responses such as proteolysis of thylakoid membrane proteins during photosystem assembly or in response to environmental changes (Barry et al., 2012). Simirarly to role of Deg proteases, FtsH protease, an ATP-dependent zinc metalloprotease, play a role in light-induced turnover of D1 protein in thylakoid membranes maintaining PSII reaction centre integrity (Lindhal et al., 2000). Matrix metalloproteinases (MMPs), based on their expression level, may have a role in remodelling of extracellular matrix during developmental processes, such as leaf 
expansion in soybean (Pak et al., 1997) or senescence and cell death in cotyledon development of cucumber (Delorme et al., 2010). Moreover, At-MMP2 insertion mutant was characterized by late flowering and early senescence in Arabidopsis (Golldack et al., 2002). Interestingly, expression of several MMPs is induced upon pathogen infection, e.g. Gm2MMP in soybean (Liu et al., 2001) or Nt1-MMP in tobacco after Pseudomonas syringae infection (Schiermeyer et al., 2009). So far there are only a few studies that verify MMP's role in abiotic stress responses. Golldack et al., (2002) revealed transcriptional activation of At2MMP by cadmium in the leaves and by salt stress in the roots of 4-week old Arabidopsis plants and tightly controlled in a organ-specific way.

Aspartic proteases are divided into 14 subfamilies and assembled into six clans based on their evolutionary relationship and tertiary structure. The majority of aspartic poteases belongs to the $\mathrm{A} 1$ family (Simoes and Faro 2004). Their functions are still unclear but there are already a few precedents suggesting their involvement in protein turnover of different developmental processes, e.g. PROMOTION OF CELL SURVIVAL1 (PCS1) gene is involved in PCD as an anti-cell-death component during embryogenesis and gametogenesis (Ge et al., 2005) or CONSTITUTIVE DISEASE RESISTANCE 1 (CDR1) gene is overexpressed under different stress conditions and triggers resistance to Pseudomonas syringae (Simoes and Faro 2004). Their role in abiotic stress is still poorly understood but there are some exceptions. Overexpression of ASPARTIC PROTEASE IN GUARD CELL 1 (ASPG1) gene could contribute to drought avoidance via ABA-dependent signalling in Arabidopsis (Yao et al., 2012). Importantly, Li et al. (2016) revealed that ASPARTYL PROTEASE CLEAVING BAG1 (Bcl-2-associated athanogene) (PCB1) promotes autophagic cell death and resistance againts $B$. cinerea by cleaving BAG6, a central mediator of fungal pathogen-associated molecular pattern perception and signaling.

\subsection{Cysteine proteases}

Cysteine (Cys) protease family is the largest protease family besides serine hydrolases (Beers et al., 2004). Cys proteases contain Cys residues in their active site and acts as a nucleophile in the first step of proteolysis (van der Hoorn et al., 2004). They are very stable enzymes and are often found in a proteolytically active, slightly acidic environment such as the apoplast or vacuole. Cys proteases are considered to co-regulate PCD and have been intensively studied in the past decades. Most of these studies focus on their roles in biotic stress whereas little is known about their activity during abiotic stress especially in case of salinity (Beers et al., 2000; Bonneau et al., 2008).

Some types of PCD are regulated by vacuolar processing enzymes (VPEs), and by papain-like Cys proteases (PLCPs). PLCPs are the most abundant among Cys proteases 
and form a large protease family, encoded by $\sim 30$ genes/plant and classified into nine subfamilies (RD21A-, CEP1-, XCP2-, XBCP3-, THI1-, SAG12-, RD19A-, AALP- and CTB3like proteases) based on their conserved functional and structural features (Turk et al., 1997; Richau et al., 2012). They typically have the MW ranging from 20- to $40 \mathrm{kDa}$ (van der Hoorn et al., 2004). The global protein structure of PLCPs is a papain-like fold of two domains, an $\alpha$ helix and a $\beta$-sheet domain. There are two domains linked to each other and between them a deep cleft is formed that acts as the substrate-binding groove containing the catalytic triad of Cys-His-Asn. Besides substrate-binding groove substrate specificity is accomplished by the substrate-binding pockets that bind amino acid side chains at positions 2 and 3 before the cleavage site. PLCPs of all subfamilies carry two pairs of highly conserved Cys residues that make disulfide bridges 1 and 2 in the a-helix domain (Fig.5; Turk et al., 2001; Richau et al., 2012).
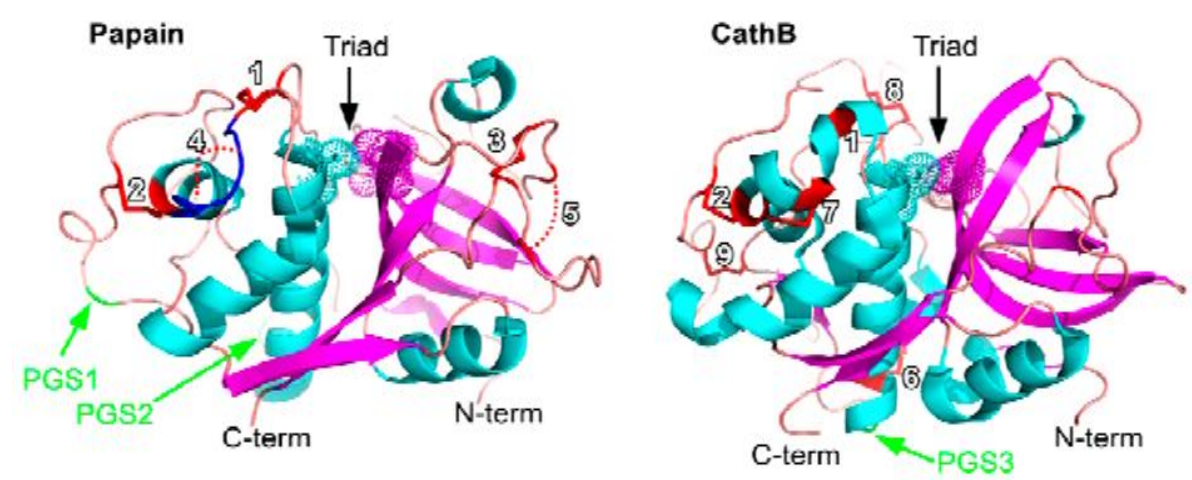

Figure $5 \quad \alpha$-helix and a $\beta$-sheet conserved structural features in PLCP subfamilies. Positions of catalytic triad, disulfide bridges (red lines) and putative N-glycosylation sites (PGS; green lines) mapped onto the crystal structure of papain and cathepsin (Richau et al., 2012).

However, there are some exceptions carrying only one- (CTB3-like proteases) or an additional, altogether two Cys residues (RD19A-like proteases, SAG12-like proteases) (Richau et al., 2012). Although they belong to Cys proteases, they can be found in different compartments. To target their location, PLCPs are synthesized as a pre-proprotein and carry different domains such as signal peptide to enter e.g. the endomembrane system or endoplasmic reticulum $(E R)$ with C-terminal KDEL-tail $(\{\mathrm{K} / \mathrm{H}\} \mathrm{DEL})$ or N-terminal NPIR motif for vacuolar targeting and autoinhibitory domain to prevent premature activation (Fig.6; Ahmed et al., 2000; Than et al., 2004). During maturation processes the prodomain is proteolytically removed either in cis or in trans conformations and they reach their active form. Finally, some PLCP subfamilies typically carry an additional granulin domain (Cx5Cx5CCCx7Cx4CCx6CCx5CCx6Cx6C). Granulin domain fusion with PLCP is unique in plant kingdom and granuling-containing PLCPs are specific to RD21A-like proteases and XBCP3-like proteases (Richau et al., 2012). 


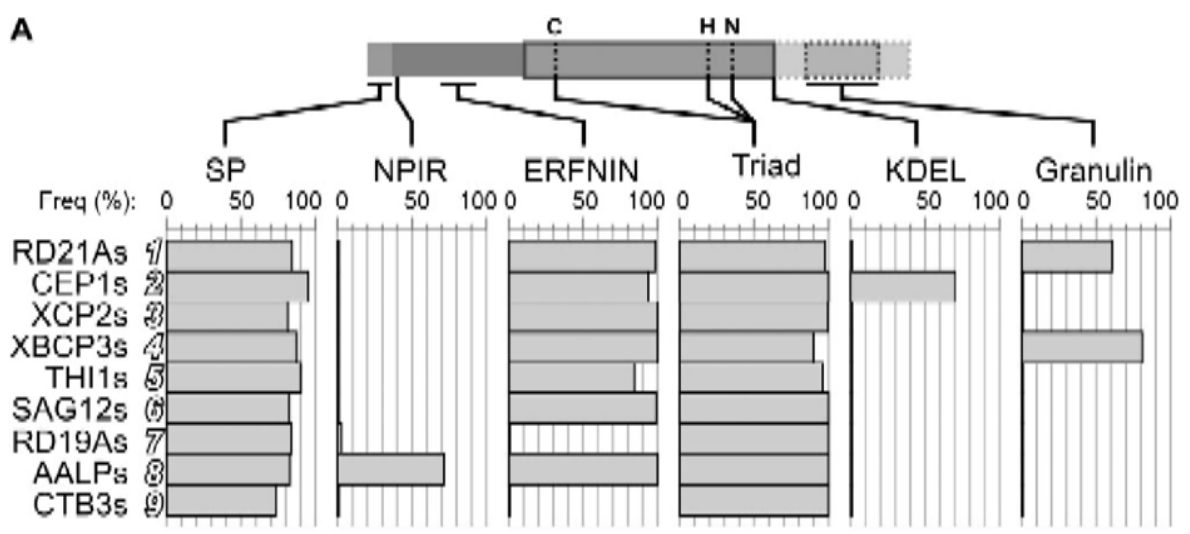

Figure 6 Conserved functional motifs in PLCP subfamilies. Positions and frequencies of functional motifs in each PLCP subfamily. SP, N-terminal signal peptide, predicted by SignalP; NPIR, vacuolar targeting signal at the $N$ terminus of the prodomain; ERFNIN,

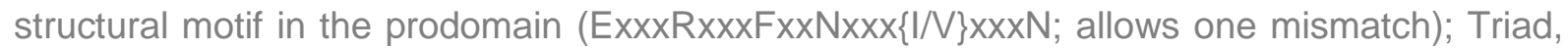
the catalytic triad: Cys-His-Asn; KDEL, C-terminal retrieval signal for localization to the ER $(\{\mathrm{K} / \mathrm{H}\} \mathrm{DEL}) ; \quad$ Granulin, C-terminal granulin domain containing the Cys pattern Cx5Cx5CCCx7Cx4CCx6CCx5CCx6Cx6C (Richau et al., 2012).

The structure and regulation of PLCPs are well-defined but their biological functions are mostly unknown. Stress-induced protein processing is highly investigated in animals. Different stress conditions trigger the activation of caspases (Cys containing Asp-specific proteases) in animal cells which is the first step in stress signalling. Caspase- 3 is the main effector in the processing cascade (Tawa et al., 2004). Caspase homologues have not been found in plant genomes but plants exhibit caspase-like-protease activity (cleaving after Asp residues) (Han et al., 2012). For example, VPE has caspase-1 activity and is required for virus-induced PCD in tobacco (Hatsugai et al., 2004), whereas the $\beta 1$ catalytic subunit of the $20 \mathrm{~S}$ proteasome has caspase-3 activity that is required for PCD triggered by Pseudomonas syringae pv. tomato DC3000 (Hatsugai et al., 2009).

Benzothiadiazole (BTH, benzothiadiazole; an SA analogue) treatment induces PLCP activity in the apoplast of tomato (Shabab et al., 2008), which was predominantly caused by the accumulation of the PIP1 protease (Tian et al., 2007; Shabab et al., 2008). Many PLCPs are up-regulated during abiotic stress (Evers et al., 2012). Transcript levels of two PLCPs, RD19 and RD21, are up-regulated during cold- or heat-stress and are strongly induced after 10 hours upon $250 \mathrm{mM} \mathrm{NaCl}$ in Arabidopsis (Koizumi et al., 1993). In addition, transcription of many PLCPs is induced upon developmental senescence in Arabidopsis leaves (Buchanan-Wollaston et al., 2005), in autumn leaves in poplar trees (Guo et al., 2004) and in response to ozone exposure in maize leaves (Ahmad et al., 2014). 


\subsection{Ubiquitin proteasome system}

Ubiquitin proteasome system (UPS) is a principal mechanism for protein degradation therefore is essential for normal plant development, for effective and efficient perception and response to environmental stress (Stone et al., 2014). Ubiquitin (Ub) is a small, highly conserved peptide that contains seven lysine residues, which all can form covalent Ub-Ub bond. According to the ubiquitin modification, this process can be divided into three types: mono- or multimonoubiquitination when Ub can be attached to either one or multiple lysine residues within one target, or polyubiquitination when a chain of Ubs attached to a lysine residue within the substrate (Stone et al., 2014). Basically, UPS is built up by successive steps starting with ubiquitination where ubiquitin molecules are covalently attached to the protein targets through the action of three enzymes, called E1, E2 and E3, second, followed by Ub-protein recognition and finally by degradation by $26 \mathrm{~S}$ proteasome complex (Vierstra 2003). In the initial step, E1 (Ub-activating enzyme) activates Ub in an ATP-dependent manner and forms a thiolester bond with the C-terminal glycine of $\mathrm{Ub}$ then activated $\mathrm{Ub}$ is transferred to E2 (Ub-conjugating enzyme) forming a thioester linked E2-Ub intermediate (Vierstra 2003; Moon et al., 2004).

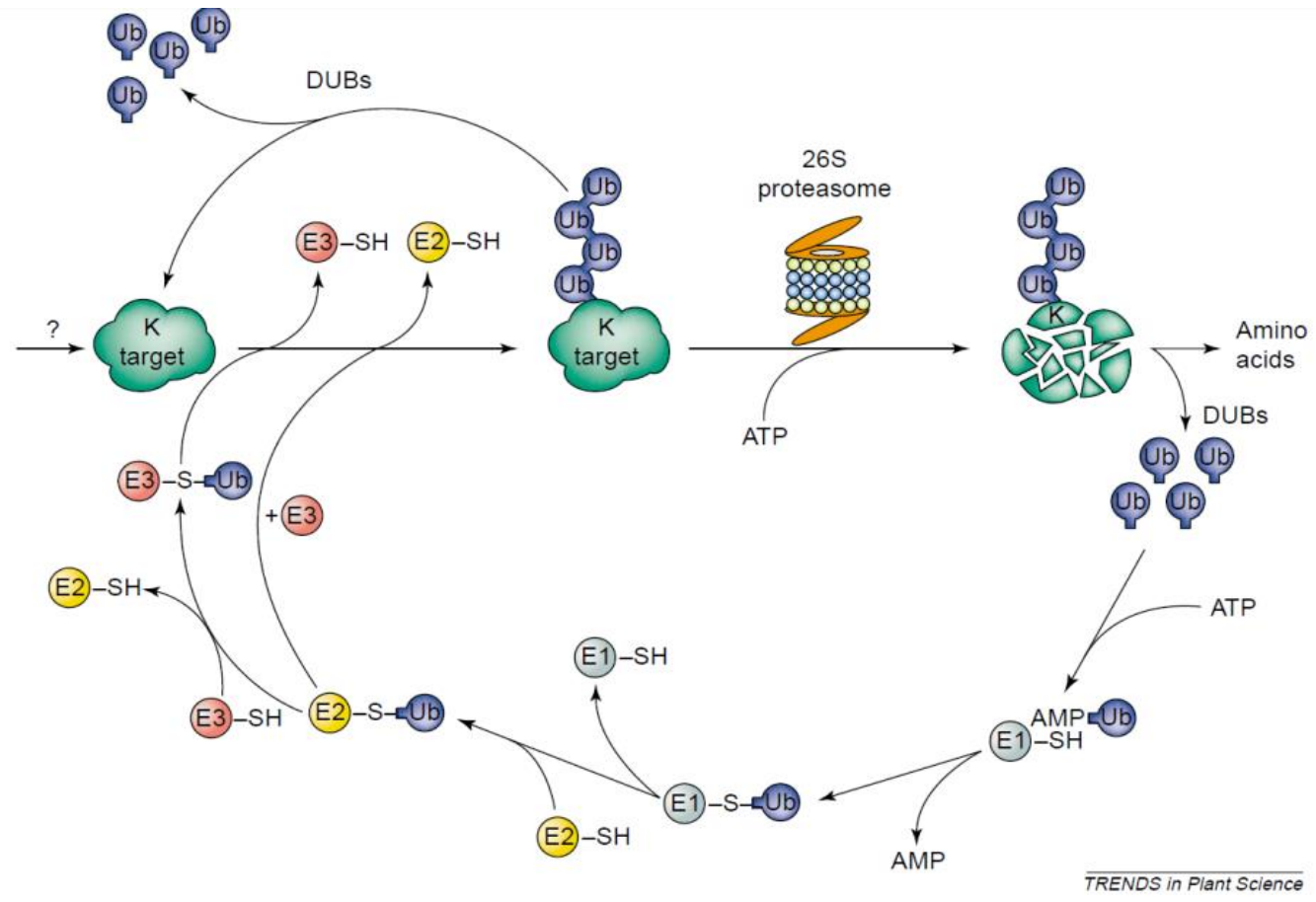

Figure $7 \quad$ Ub and ATP-dependent UPS pathway. Ubiquitin conjugation cascade requires E1, E2 and E3 for activation, conjugation and ligation. Once Ub attached to the target protein and polyUb-chain assembled, it is either recognized and degraded by $26 \mathrm{~S}$ proteasome complex or polyUb is disassembled by deubiquitination enzymes (DUBs) (Vierstra et al., 2003). 
The third enzyme is E3 (ubiquitin ligase), the central component of ubiquitination pathway, interacts with E2-Ub complex and transfers $\mathrm{Ub}$ to the recruiting substrate and finally, initiate the conjugation (Fig.7; Stone 2014).

This process can be repeated several times to assemble a Ub-chain, since polyubiquitination is necessary for degradation by $26 \mathrm{~S}$ proteasome (Wilkinson 2000). Interestingly, besides protein degradation, ubiquitination may have a role in cell signalling e.g. in intracellular trafficking or in the activation of transcription by displacing a histone $\mathrm{H} 2 \mathrm{~A} / \mathrm{H} 2 \mathrm{~B}$ dimer from the nucleosome, respectively (Chen and Sun 2009). The Ub-substrate conjugation process is reversible. DUBs specifically remove covalently bound Ubs from the substrate and generate free Ubs which can be recycled (Fig.7).

Importantly, it has been discovered that there is another Ub-, and ATP-independent protein degradation pathway required either 20S proteasome complex or 26S proteasome complex (Fig.8). Proteins having partially or fully unstructured regions due to oxidation, mutation or aging are susceptible to 20 S degradation (Ben-Nissan and Sharon 2014).
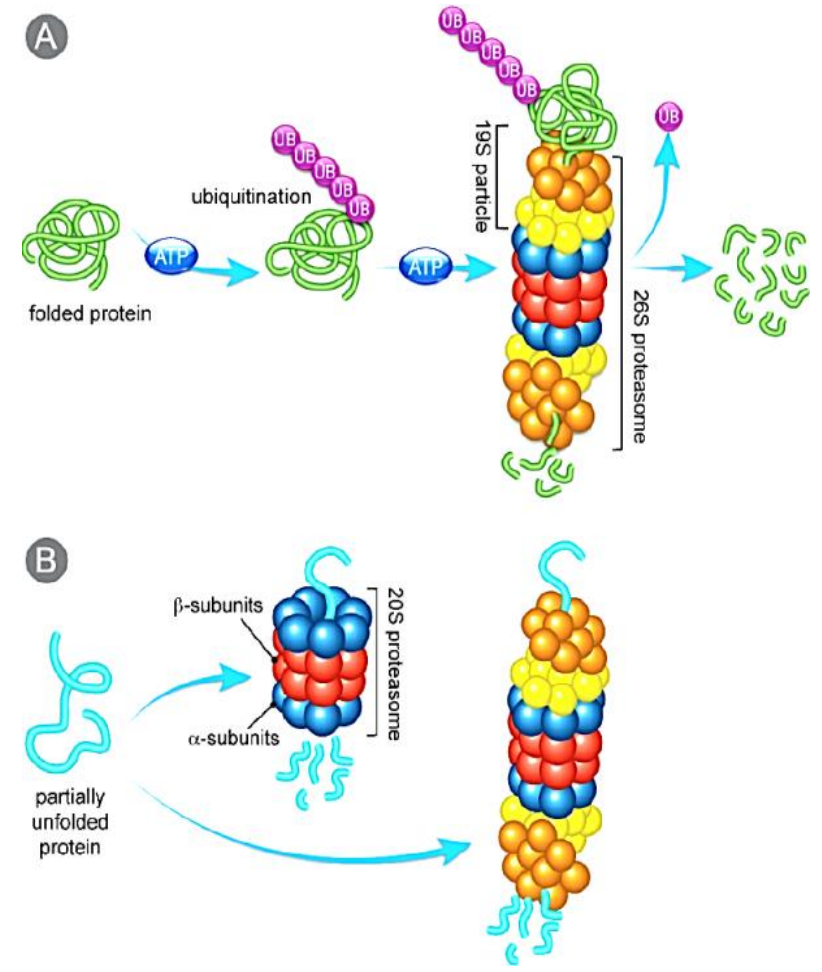

Figure 8 Possible degradation pathways mediated by proteasome. Target protein degradation can occur either by (A) ATP- and Ub-dependent pathway requireing polyubiquitination and then the target is degraded by $26 \mathrm{~S}$ proteasome or (B) ATP- and Ubindependent pathway without Ub tagging and ATP and then the target is degraded by $20 \mathrm{~S}$ proteasome core complex or 26 S proteasome (Garzia-Lorenz 2007). 


\subsection{Proteasome}

The $26 \mathrm{~S}$ proteasome is a highly conserved protein complex which has a crucial role in selective protein degradation during cell death and development. The proteasome participates in cell cycle progression and in signalling pathways e.g. by removing propeptides presenting antigens during immune response (Cascio et al., 2001; Ferrington et al., 2012). The $26 \mathrm{~S}$ proteasome consists of a catalytic $20 \mathrm{~S}$ core particle and a $19 \mathrm{~S}$ regulatory particle (Coux et al., 1996). The core particle is composed of four heptameric rings; two outer $\alpha$-rings and two inner $\beta$-rings, each of them composed of seven different $\alpha$ - and $\beta$ subunits (Löwe et al., 1995). These four heptameric rings are arranged as a cylinder with three large internal chambers. The active sites are in the central chamber, residing in three catalytic subunits: $\beta 1, \beta 2$ and $\beta 5$ which cleave after acidic, basic and hydrophobic residues, respectively, (Löwe et al., 1995; Murata et al., 2009), and representing caspase-like, trypsin-like and chymotrypsin-like activity, respectively (Gu et al., 2010).

In addition to the standard $\beta 1, \beta 2$ and $\beta 5$ subunits, animals have additional "immune"subunits $(\beta 1 \mathrm{i}, \beta 2 \mathrm{i}, \beta 5 \mathrm{i})$ and a thymus-specific subunit $(\beta 5 \mathrm{t})$ which can replace the conventional catalytic subunits in different combinations (Klare et al., 2007; Murata et al., 2007; Ben-Nissan and Sharon 2014). Replacement of standard subunits by the "immune"subunits creates the immunoproteasome (i-20S) (Aki et al., 1994). These immune-subunits can also co-exist with standard subunits within the same proteasome complex, creating an intermediate-type proteasome (Klare et al., 2007). Intermediate- and immuneproteasomes play roles in the degradation of damaged and misfolded proteins during cell death, especially in oxidizing conditions in animals. Their level depends on the status of disease (Zheng et al., 2012; Grigoreva et al., 2015).

Interestingly, there are indications of the existence of an alternative proteasome in plants. A defense-induced $\alpha 3, \alpha 6$ and $\beta 1$ subunits ( $\alpha 3$ din, $\alpha 6 \mathrm{din}$ and $\beta 1 \mathrm{din}$ ) in tobacco suggest for the presence of a "defense proteasome" in plants (Suty et al., 2003). Transcripts of $\alpha 3$ din, $\alpha 6 \mathrm{din}$ and $\beta 1$ din were upregulated by cryptogein, a fungal elicitor in tobacco (Dahan et al., 2001; Lequeu et al., 2005). "Defense proteasome" was also revealed to be tightly correlated with systemic acquired resistance (SAR) in different model systems (Suty et al., 2003). Further evidence suggests that proteasome regulates biotic stress responses, e.g. 26S proteasome was required for SA accumulation againts fungi (Yao et al., 2012). Nevertheless proteasome-dependent defense response to Pseudomonas syringae infection involved vacuolar membrane and PM fusion resulting vacuolar proteases and antibacterial proteins release to the apoplastic fluid where bacteria proliferate (Hatsugai et al., 2009).

Furthermore, the $20 \mathrm{~S}$ proteasome activity declines in sunflower leaves after treatment with certain heavy metals (Pena et al., 2008). But little is known about the modification and 
activation of specific proteasome subunits in plants. 26S proteasome regulatory particle mutants have increased oxidative stress tolerance (Kurepa et al., 2008), salt hypersensitivity of the rpn1a mutants also confirms a recent discovery on the importance of optimal $26 \mathrm{~S}$ proteasome function for maintaining plant drought stress tolerance (Cho et al., 2008; Yee and Goring 2009; Wang et al., 2009).

\subsection{Activity-based protein profiling (ABPP)}

In the context of gene expression studies it would be important to highlight that change in gene expression level does not necessarily mean the same alteration in activity of the corresponding enzyme proteins with proteolytic activity (Vaseva et al., 2012). To solve this problem we applied activity-based protein profiling (ABPP), a simple and robust tool that is suitable to detect and visualize the functional state of subsets of enzymes.

ABPP was originally developed for medical biochemistry, e.g. to show the selectivity of drugs or as a diagnostic tool for cancer therapy (Daneri-Castro et al., 2016), but has been successfully translated into plant science and it is increasingly used in the past decade on plant field (Morimoto and van der Hoorn 2016). ABPP takes advantage of small bioreactive molecules, called activity-based probes (ABPs) that react with the active site of the enzyme in an activity-dependent manner, creating an irreversible covalent bond (Fig.9B; Morimoto and Van der Hoorn, 2016). ABP consists of three regions: warhead-, linker- and reporter region (Fig.9A; Kolodziejek et al., 2010).

There are four types of chemical probes (Cravatt et al., 2008; Kovács and van der Hoorn 2016; Morimoto and Van der Hoorn 2016). i) Mechanism-based probes are often inspired on a covalent, mechanism-based inhibitor (e.g. DCG-04 is biotinylated version of protease inhibitor E-64 (Greenbaum et al., 2000)). ii). Photoaffinity probes are reversible inhibitors equipped with a photoreactive group that facilitates crosslinking upon UV irradiation (e.g. JL01 for metalloproteases (Lenger et al., 2012)). iii). Suicide probes become reactive upon activation by the enzyme and usually react when still in the substrate binding pocket (e.g. ethynylnapthalene for cytochrome P450s (Wright et al., 2007)). iv). Reactivity probes lack a binding group and preferentially react with hyper-reactive residues that are often active site residues (e.g. iodoacetamide probes for hyper-reactive Cys residues (Weerapana et al., 2010)) (Fig.9A; Kovács and van der Hoorn 2016). 


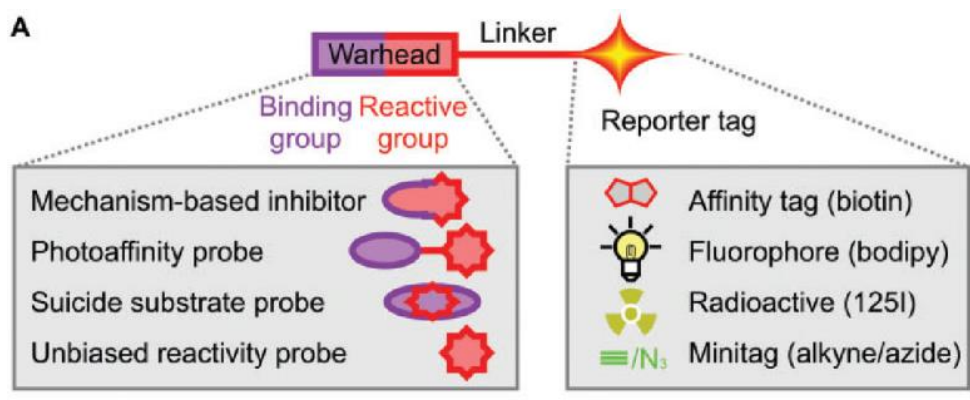

B

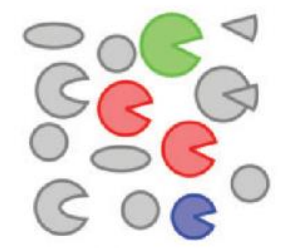

Proteome

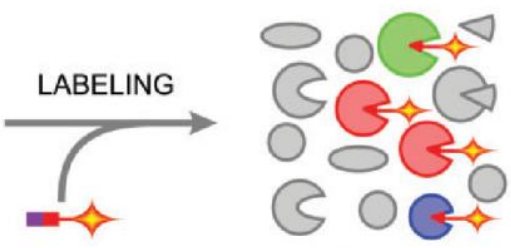

Labeled proteome

Figure 9 Principle of ABPP. (A) Four types of probes and reporter tags. Mechanismbased probes are based on irreversible inhibitors that mimic a substrate by locking the enzymatic mechanism in the covalent intermediate state. Photoaffinity probes are based on reversible inhibitors equipped with a photoreactive group that cross-links within the inhibitorbinding site. Suicide substrate probes are based on suicide inhibitors that become reactive upon enzymatic activity and often react within the substrate-binding site. Unbiased reactive probes consist of a tuned reactive chemical warhead that preferentially reacts with hyperreactive residues. (B) Concept of proteome labeling with chemical probes (Morimoto and Van der Hoorn, 2016).

Comparative ABPP is one of the major applications of ABPP that displays changes in the activity level of the enzymes upon different treatments (Fig.10A), for instance, in the activity of PLCPs upon biotic stress, or VPEs and proteasome during PCD (Shabab et al., 2008; Kaschani et al., 2009; Gu et al., 2012; van der Linde et al., 2012; Misas-Villamil et al., 2013ab; Sueldo et al., 2014).
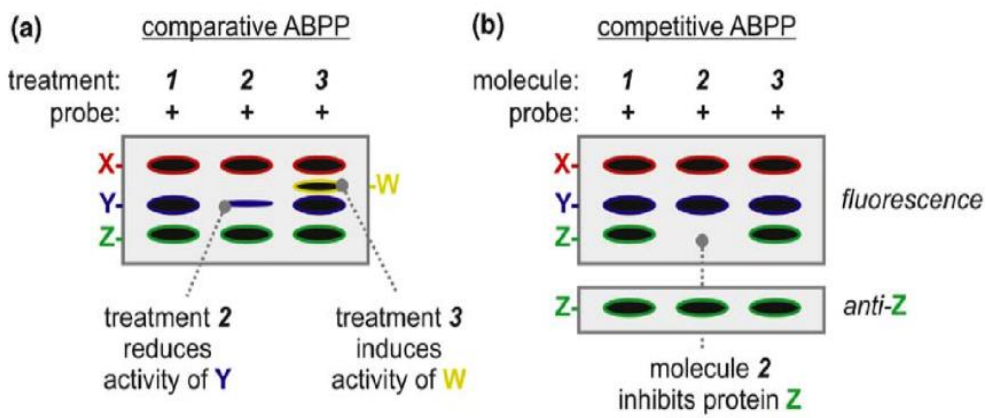

Figure 10 Principle of comparative and competitive ABPP. (a) Comparative ABPP compares protein activities of proteomes of different samples. (b) Competitive ABPP uncovers inhibitors. Putative inhibitors are preincubated with the proteome and the probe is added to label the remaining active proteins. The absence of a signal indicates that molecule 2 inhibits protein Z (Kołodziejek and van der Hoorn et al., 2010). 
Another basic application of ABPP is competitive ABPP that is used for confirming whether the signal caused by the certain enzyme (Fig.10B; Kołodziejek and van der Hoorn et al., 2010).

ABPs are often derived from a corresponding inhibitor and are linked to a reporter tag such as biotin or fluorophore. The detection method depends on the reporter tag. Detection of fluorophore probes is simple separation on protein gel and scan for fluorescence. Biotinylated probes are detected with western blot and proteome labeled with biotinylated probe can be purified and identified by in-gel or by on-bead digestion and MS analysis. Alternatively, whole labeled proteomes are digested in-solution and biotinylated peptides are purified and identified by MS (Fig.11, TableS1; Kovács and van der Hoorn 2016; Morimoto and Van der Hoorn 2016). 


\section{Objectives}

Our aim was to investigate the main differences between the effects of sublethal (100 $\mathrm{mM} \mathrm{NaCl})$ and lethal $(250 \mathrm{mM} \mathrm{NaCl})$ salt stress on tomato plants. We were interested in the physiological and molecular changes depending on whether the plants survive or or the stress induces PCD. In addition, contribution of ABA deficiency to salt stress sensitivity was studied in sitiens mutants deficient in ABA biosynthesis and thus in ABA content focusing on the early events of PCD.

We focused on the following questions:

1. What are the common and distinct features in the response of tomato upon 100- and $250 \mathrm{mM}$ salt treatments? How do different organs react to salt stress? What are the differences between responses of roots and leaves upon early stages of salt stress?

2. Is it possible to determine at the early stages of salinity that the plant will turn into survival or PCD according to the stress responses? Do ROS burst and NO peak occur at the same time upon salt-induced PCD and do they disappear upon sublethal treatment? Can we consider the alteration of ROS burst and NO level as a hallmark of salt-induced PCD in tomato?

3. Are there any effects of salt treatment on the protease activity in tomato? How does protein turnover and protease activity change upon the two different salt treatments?

4. It is well known that triggered activity of caspases is amongst the first step in stress signalling in animals. Caspase-like activity was also observed in plants including Cys proteases. Is there any possibility that Cys proteases have similar importance in plants? Is there any organ specificity in the activity of Cys proteases? Is there any correlation between the alteration of Cys proteases at gene expression level and at protein level?

5. VPEs are the other subfamily belonging to Cys proteases which have caspase 1-like activity. Previously, it has been discovered that they have pivotal role in response to biotic stress. Is there any role of VPEs in salt stress-induced PCD or defense mechanisms in tomato? If yes, is it a universal or a organ-specific alteration?

6. Two main protein degradation pathways exist in plants, the above mentioned proteasebased and the proteasome-based pathways. Does the activity of proteasome catalytic 
subunits alter upon the sublethal- and lethal salt stress? Does it contribute to defense against salt stress or does it support PCD?

7. How does ABA deficiency modify the sensitivity of tomato roots to salt stress, specifically to sublethal salt stress? What kind of physiological or molecular responses will change in sitiens roots under control and different salt stress conditions? Does ABA have role in the decrease in cell viability or in membrane integrity of root cells?

8. How do ROS burst and NO production change in tomato roots with reduced $A B A$ content? Does ABA deficiency affect total protease activity? Does protein level significantly decrease or increase in sitiens roots? 


\section{Materials and methods}

\subsection{Plant Material-and Growth Conditions}

Tomato (Solanum lycopersicum L. cv. "Rio Fuego") and sitiens mutant (Solanum lycopersicum cv. "Rheinland") plants were germinated at $26{ }^{\circ} \mathrm{C}$ for 3 days in the dark, and the seedlings were subsequently transferred to perlite for 2 weeks. Plants were grown hydroponically in a controlled environment in a greenhouse $\left(300 \mu \mathrm{mol} \mathrm{m} \mathrm{m}^{-2} \mathrm{~s}^{-1}\right.$ photon flux density with $12 / 12$ light/dark photoperiod, $25^{\circ} \mathrm{C}$, and $55-60 \%$ relative humidity) for 3 weeks (Poór et al., 2011). Tomato plants were treated with 0-, 100- and $250 \mathrm{mM} \mathrm{NaCl}$ in the nutrient solution $\left(2 \mathrm{mM} \mathrm{Ca}\left(\mathrm{NO}_{3}\right)_{2}, 1 \mathrm{mM} \mathrm{MgSO}_{4}, 0.5 \mathrm{mM} \mathrm{KCl}, 0.5 \mathrm{mM}, \mathrm{KH}_{2} \mathrm{PO}_{4}, 0.5 \mathrm{mM} \mathrm{Na} \mathrm{HPO}_{4}\right.$, $0.001 \mathrm{mM} \mathrm{MnSO}_{4}, 0.005 \mathrm{mM} \mathrm{ZnSO}_{4}, 0.0001 \mathrm{mM}\left(\mathrm{NH}_{4}\right)_{6} \mathrm{Mo}_{7} \mathrm{O}_{24}, 0.01 \mathrm{mM} \mathrm{H}_{3} \mathrm{BO}_{4}, 0.02 \mathrm{mM}$ $\mathrm{Fe}(\mathrm{III})$-EDTA). Treatments were performed at 9 a.m. and samples were taken in triplicate at 1,6 and 24 hours after salt exposure.

\subsection{FDA Staining}

Fluorescein diacetate (FDA; Sigma-Aldrich, St. Louis, MO) was used to determine cell viability according to Gémes et al. (2011). Root tip segments were stained for $10 \mathrm{~min}$ at room temperature in the dark with $10 \mathrm{mM}$ FDA dissolved in $3 \mathrm{ml} 10 \mathrm{mM} 2-(\mathrm{N}-$

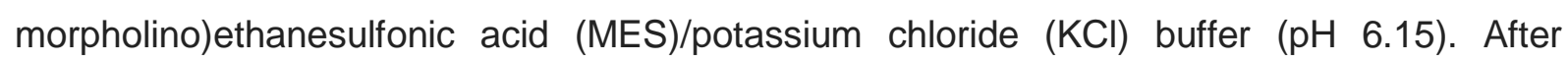
staining, the samples were washed two times in $10 \mathrm{~min}$ with $\mathrm{MES} / \mathrm{KCl}$ buffer $(\mathrm{pH} 6.15)$. Fluorescence intensity was detected with Zeiss Axiowert 200M type fluorescent microscope (Carl Zeiss Inc., Jena, Germany) equipped with an 5X objective. Digital photographs were taken from the samples with a high-resolution digital camera (Axiocam HR, HQ CCD camera; Carl Zeiss Inc., Jena, Germany) using a filter set 10 (excitation 450-495 nm, emission 515$565 \mathrm{~nm}$ ) or filter set 20HE (excitation: 535-585 nm, emission: 600-655 nm). The fluorescence emission (pixel intensity) was measured on digital images with AXIOVISION REL. 4.8 software (Carl Zeiss Inc., Munich, Germany).

\subsection{Electrolyte leakage and elemental analysis}

Cell death was determined with the measurement of electrolyte leakage (EL) by the method of Poór et al. (2014). One g of root segments was transferred to $15 \mathrm{~mL}$ of double distilled water. After $2 \mathrm{~h}$ of incubation at $25{ }^{\circ} \mathrm{C}$, the conductivity of the bathing solution was determined (C1) with conductivity meter (OK-102/1 Radelkis, Budapest, Hungary). Samples were then heated at $95^{\circ} \mathrm{C}$ for $40 \mathrm{~min}$ and the total conductivity (C2) was measured. Relative 
electrolyte leakage (EL) was expressed as a percentage of total conductivity: $\operatorname{EL}(\%)=$ $100 \times(C 1 / C 2)$.

Plant samples (root tissues and apical root segments) were collected on filter paper, washed twice with $50 \mathrm{~mL}$ double distilled water, one $\mathrm{g}$ were put into glass tubes (Packard, Groningen, Netherlands) and dried $\left(80^{\circ} \mathrm{C}, 24 \mathrm{~h}\right)$. After measuring the dry weight (DW), $6 \mathrm{~mL}$ $\mathrm{HNO}_{3}$ (Reanal, Budapest, Hungary) and $2 \mathrm{~mL} 30 \% \mathrm{H}_{2} \mathrm{O}_{2}$ (Reanal, Budapest, Hungary) were added to $100 \mathrm{mg}$ plant material for $20 \mathrm{~h}$. The samples were digested in microwave destructor (MarsXpress CEM, Matthews NC, USA) at $200{ }^{\circ} \mathrm{C}$ for $25 \mathrm{~min}$ and after cooling they were diluted with $12 \mathrm{~mL}$ double distilled water. Potassium and sodium contents of the root cells were determined by AAS (Hitachi Z-8200, Tokyo, Japan) (Poór et al., 2014).

\subsection{Detection of ROS and NO}

ROS was visualized by using $10 \mu \mathrm{M}$ 2',7'-dichlorodihydrofluorescein diacetate $\left(\mathrm{H}_{2} \mathrm{DCFDA}\right)$ for $20 \mathrm{~min}$ in $10 \mathrm{mM}$ MES-TRIS/KCI buffer (pH 5.8) in the dark at $37^{\circ} \mathrm{C}$ and rinsed once with $10 \mathrm{mM}$ MES-TRIS/KCl buffer ( $\mathrm{pH}$ 5.8) (Gémes et al. 2011). NO production was visualized using $10 \mu \mathrm{M} \mathrm{4,5}$ diaminofluorescein-diacetate (DAF-2 DA) for 20 min in 10 $\mathrm{mM}$ MES-TRIS/KCI buffer ( $\mathrm{pH}$ 5.8) in the dark at room temperature and rinsed once with 10 mM MES-TRIS/KCl buffer ( $\mathrm{pH}$ 5.8) (Gémes et al. 2011). Fluorescence intensity was detected with Zeiss Axiowert 200 M-type fluorescent microscope (Carl Zeiss Inc., Jena, Germany) equipped with an objective $\times 10$. Digital photographs were taken from the samples with a high-resolution digital camera (Axiocam HR, HQ CCD camera; Carl Zeiss Inc., Jena, Germany) with a filter set 10 (excitation 450-495 nm, emission 515-565 nm). Fluorescence intensities (pixel intensity) were measured on digital images within circular areas of $45 \mathrm{Im}$ radii using Axiovision Rel. 4.8 software. The radii of circles were not modified during the experiments.

\subsection{Determination of the $\mathrm{H}_{2} \mathrm{O}_{2}$ level}

The $\mathrm{H}_{2} \mathrm{O}_{2}$ level was measured spectrophotometrically as described by Horváth et al. (2015) with some modifications. After homogenisation of $200 \mathrm{mg}$ of tissues with ice-cold 1 $\mathrm{mL}$ of $0.1 \%$ trichloroacetic acid (TCA), the samples were centrifuged at $10.000 \mathrm{~g}$ for $20 \mathrm{~min}$ at $4{ }^{\circ} \mathrm{C}$. The reaction mixture contained $0.25 \mathrm{~mL}$ of a $10-\mathrm{mM}$ phosphate buffer $(\mathrm{pH} 7.0), 0.5$ $\mathrm{mL}$ of $1-\mathrm{M}$ potassium iodide $(\mathrm{KI})$ and $0.25 \mathrm{~mL}$ of the supernatant. The absorbance of the samples was measured after $10 \mathrm{~min}$ at $390 \mathrm{~nm}$. The amount of $\mathrm{H}_{2} \mathrm{O}_{2}$ was calculated using a standard curve prepared from the dilution of $\mathrm{H}_{2} \mathrm{O}_{2}$ stock solution. 


\subsection{Determination of protein concentration}

For the analysis of the soluble protein concentration was determined according to Bradford (1976) using bovine serum albumin as a standard.

\subsection{Determination of proteolytic activity}

\subsubsection{Azocasein assay}

Azocasein (SigmaeAldrich, St. Louis, MO) was applied as a nonspecific substrate to measure the total proteolytic activity. $50 \mu \mathrm{l}$ of tissue extract, $300 \mu \mathrm{l} 1 \%$ azocasein $(\mathrm{w} / \mathrm{v})$ and $650 \mu \mathrm{l}$ potassium phosphate buffer $(\mathrm{pH} 5.5)$ were incubated at $37^{\circ} \mathrm{C}$ for $2 \mathrm{~h}$. The reaction was stopped by the addition of $300 \mu 10 \%(w / v)$ trichloroacetic acid (TCA) at $4{ }^{\circ} \mathrm{C}$ for $20 \mathrm{~min}$. After $20 \mathrm{~min}$ on ice, the samples were centrifuged (10 min at $\left.4{ }^{\circ} \mathrm{C}, 11300 \mathrm{~g}\right)$ and the yellow color of the supernatant was measured at $440 \mathrm{~nm}$. One unit of total proteolytic activity (U) was defined as the amount of enzyme yielding 0.01 unit of absorbance per min under the assay conditions.

\subsubsection{Gelatin-SDS PAGE}

$20 \mu \mathrm{g} / \mathrm{ml}$ protein extract was loaded in each lane on 12,5\% SDS PAGE containing $0,1 \%$ gelatin substrate with a $5 \%$ stacking gel overlaid. The proteins were run under denaturing conditions at $90 \mathrm{~V}$ for $20 \mathrm{~min}$, then at $70 \mathrm{~V}$ for $120 \mathrm{~min}$ (Grudkowska and Zagdanska 2010; Rossano et al., 2011). The gels were then renatured in 2.5\% Triton X-100 twice for $40 \mathrm{~min}\left(40 \mathrm{rpm}, 25^{\circ} \mathrm{C}\right)$ and developed in incubation buffer (50 mM Tris- $\mathrm{HCl}, 5 \mathrm{mM}$ $\left.\mathrm{CaCl}_{2}, 2 \mathrm{mM} \mathrm{MgCl}_{2}, \mathrm{pH} 5,5\right)$ overnight at $37^{\circ} \mathrm{C}$. Gels were stained in $250 \mathrm{ml}$ of $0,1 \%$ Coomassie R-250 containing 40\% methanol and 10\% acetic acid for 30 min and destained in $40 \%$ methanol and 10\% acetic acid solution twice for $30 \mathrm{~min}$. Gels were stored in distilled water till development. Areas of protease activity were revealed as cleared bands on a blue background (Wagstaff et al., 2002). The images were quantified using ImageJ 1.48V.

\subsection{Small-Scale Labelling Reaction}

\subsubsection{Sample preparation}

Root tissue was homogenized in $50 \mathrm{mM}$ Tris buffer at $\mathrm{pH} 7.5$ containing $5 \mathrm{mM}$ DTT for labelling of the proteasome. The extract was mixed and centrifuged at $10000 \mathrm{~g}$ for $10 \mathrm{~min}$ at $4{ }^{\circ} \mathrm{C}$ to remove cell debris and the supernatant was collected and used for labelling. 


\subsubsection{Labelling of PLCPs}

Protein extract of $100 \mu \mathrm{g} / \mathrm{ml}$ was incubated with $0.3 \mu \mathrm{M} \mathrm{MV} 201$ for 4 hours at room temperature in the dark in $200 \mu \mathrm{l}$ of total volume. Equal volumes of dimethyl sulfoxide (DMSO) were added for the no-probe-control. For inhibition assays, protein extracts were pre-incubated with $50 \mu \mathrm{M}$ E64 or DMSO for $30 \mathrm{~min}$ at room temperature and these extracts were labelled with $0.3 \mu \mathrm{M}$ MV201. The labelling reaction was stopped by precipitation using the chloroform/methanol precipitation protocol (Friedman 2007). $1 \mathrm{X}$ SDS-PAGE loading buffer containing $\beta$-mercaptoethanol was added to the pellet and it was heated for $10 \mathrm{~min}$ at $95^{\circ} \mathrm{C}$. The reaction mixture was separated on $12 \% \mathrm{SDS}$ gel at $200 \mathrm{~V}$ for $1 \mathrm{~h}$. Labelled proteins were visualized by in-gel fluorescence scanning using a Typhoon 9400 Imager (GE Healthcare, http://www.gelifesciences.com) at 532/580 nm excitation and emission wavelengths, respectively. Signals were quantified using ImageJ 1.48V.

\subsubsection{Labelling of proteasome subunits}

Protein extract of $100 \mu \mathrm{g} / \mathrm{ml}$ was labelled with $2 \mu \mathrm{M}$ MV151 for $3 \mathrm{~h}$ or $0.2 \mu \mathrm{M}$ MVB072 or co-labelled with $0.8 \mu \mathrm{M}$ LW124/MVB127 for $2 \mathrm{~h}$ at room temperature in the dark in $60 \mu \mathrm{l}$ total volume. Equal volumes of DMSO were added for the no-probe-control. For inhibition assays, extracts were pre-incubated with 50 or $100 \mu \mathrm{M}$ epoxomicin or with one of $50 \mu \mathrm{M}$ $\mathrm{N} 3 \beta 1, \mathrm{~N} 3 \beta 5$ or DMSO and these extracts were labelled with the suitable probe. The labelling reactions were stopped by adding gel loading buffer containing $\beta$-mercaptoethanol and they were heated at $95{ }^{\circ} \mathrm{C}$ for $10 \mathrm{~min}$. The reaction mixture was separated on $15 \%$ SDS gel at $200 \mathrm{~V}$ for $75 \mathrm{~min}$. Labelled proteins were visualized by in-gel fluorescence scanning using a Typhoon 9400 Imager (GE Healthcare, http://www.gelifesciences.com) using excitation and emission wavelengths of 532/580 nm for MV151, MVB072 and MVB127 or of 470/530 nm for LW124. 532/580 nm and 470/530 were overlaid and signals were quantified using ImageJ $1.48 \mathrm{~V}$ by multiplication of the fluorescence intensity and the area of each of the spots $(n=3)$.

\subsection{Large-Scale Labeling and Affinity Purification}

\subsubsection{Sample preparation for PLCPs}

Root tissue was homogenized in $50 \mathrm{mM} \mathrm{NaOAc}$ buffer at pH 6.0 containing 5 mM DTT. The extract was mixed and centrifuged at $10000 \mathrm{~g}$ for $10 \mathrm{~min}$ at $4{ }^{\circ} \mathrm{C}$ to remove cell debris. Supernatant was collected and preincubated with $50 \mu$ of high-capacity streptavidin agarose resin (Thermo Scientific, www.thermoscientific.com) for $30 \mathrm{~min}$ at $4{ }^{\circ} \mathrm{C}$. The mixture was 
centrifuged twice at $1400 \mathrm{~g}$ for $10 \mathrm{~min}$ at $4{ }^{\circ} \mathrm{C}$. Protein extract was cleaned by passing through a $0.22 \mu \mathrm{m}$ filter attached to a syringe.

\subsubsection{Affinity purification}

Protein extracts were separated to $500 \mu \mathrm{l}$ aliquots containing $0.5 \mathrm{mg} / \mathrm{ml}$ protein. Labelling reaction was performed by incubating $5 \mu \mathrm{M}$ DCG-04 at room temperature for $6 \mathrm{~h}$. Aliquots were collected and the reaction was stopped by precipitating the total proteins via the chloroform/methanol precipitation method (Friedman 2007). The pellet was dissolved in $1.2 \%$ SDS-PBS by sonication, then it was heated at $95^{\circ} \mathrm{C}$ for $10 \mathrm{~min}$ and diluted to $0.2 \%$ SDS-PBS by adding 1 X PBS. The resulting solution was incubated with $100 \mu \mathrm{l}$ of preequilibrated high-capacity streptavidin beads (Sigma-A9207) for $2 \mathrm{~h}$ at room temperature. The beads were collected by centrifuging at $1400 \mathrm{~g}$ for $5 \mathrm{~min}$. Beads were washed successively three times with $5 \mathrm{ml}$ of $1.2 \%$ SDS/PBS solution, three times with $5 \mathrm{ml}$ of $1.0 \%$ SDS/PBS solution, and three times with $10 \mathrm{ml}$ of $1 \mathrm{X}$ PBS buffer. The final wash occurred with $10 \mathrm{ml}$ of distilled water. The captured proteins were eluted by boiling the beads at $95{ }^{\circ} \mathrm{C}$ in $20 \mu \mathrm{l}$ of $6 \mathrm{X}$ gel loading buffer. The eluted proteins were separated on $12 \%$ protein gels at $200 \mathrm{~V}$ for $1 \mathrm{~h}$, and the protein gels were stained overnight with SYPRO Ruby (Invitrogen). To detect the proteins, we scanned the gels at an excitation wavelength of $473 \mathrm{~nm}$ with an LPG filter using a Typhoon 9400 Imager (GE Healthcare Life Sciences). Specific bands were excised from the gel and subjected to in-gel tryptic digestion and subsequent MS analysis.

\subsection{RNA extraction and expression analyses with qRT-PCR}

The expression rates of the selected genes from tomato leaves were determined by quantitative real-time reverse transcription-PCR (Piko Real-Time qPCR System, Thermo Scientific) using SYBR green dye after the extraction of RNA from $100 \mathrm{mg}$ of plant material according to Chomczynsky and Sacchi (1987) as described in Horváth et al. (2015). Tomato genes were mined from Sol Genomics Network (SGN; http://solgenomics.net/; Bombarely et al. 2011) and National Center for Biotechnology Information (NCBI; http://www.ncbi.nlm.nih.gov/) databases. Primers were designed using NCBI and Primer 3 software (http://frodo.wi.mit.edu/). The specific primers used for qRT-PCR are listed in Table S1. The PCR reaction consisted of $5 \mu \mathrm{L}$ of Maxima SYBR Green qPCR Master Mix (2X) (Thermo Scientific), 400-400 nM of forward and reverse primers, $10 \mathrm{ng}$ of cDNA template, and nuclease-free water in a total volume of $10 \mu \mathrm{L}$. The PCR protocol was as follows: denaturation at $95^{\circ} \mathrm{C}$ for $7 \mathrm{~min}$, followed by 40 cycles of denaturation at $95{ }^{\circ} \mathrm{C}$ for $15 \mathrm{~s}$ and annealing extension at $60{ }^{\circ} \mathrm{C}$ for $59 \mathrm{~s}$. To determine the specificity of the reaction, a melting 
curve analysis of the product was performed immediately after the final PCR cycle by increasing the temperature from 55 to 90 oC (0.2 oC s-1). Data analysis was performed using PikoReal Software 2.2 (Thermo Scientific). Tomato 18S rRNA and elongation factor-1 $\alpha$ subunit (EF1 $\alpha)$ genes were used as reference genes. Data from the RT-qPCR were calculated using 2(- $\Delta \Delta \mathrm{Ct}$ ) formula (Livak and Schmittgen, 2001). Each reaction was repeated at least three times as three independent cDNA extracted from at least two independent biological replicate.

\subsection{IEF 2D SDS PAGE}

Labelled and precipitated proteins were resuspended in UTC buffer (8M urea, 2M thiourea, 4\% (w/v) 3-[(3-Cholamidopropyl)dimethylammonio]-1-propanesulfonate hydrate (CHAPS), 1 g AG 501-X8 Resin) containing 1\% (v/v) ampholyte and 65 mM DTT. Samples were isoelectrically focused on $7 \mathrm{~cm}$ immobilized $\mathrm{pH}$ gradient (IPG) 3-10 pH strips (BioRadReadyStrip $^{\text {TM }}$ IPG Strips) using BioRad PROTEAN i12 IEF system with the following focusing conditions: $12 \mathrm{~h}$ passive rehydration; $250 \mathrm{~V}, 15 \mathrm{~min}$, rapid ramp; $4000 \mathrm{~V}, 1 \mathrm{~h}$, slow ramp; $4000 \mathrm{~V}, 30000 \mathrm{~V} \mathrm{hr}$, rapid ramp; $500 \mathrm{~V}$ hold. After focusing, IPG strips were equilibrated in IEF equilibration buffer (6 M urea, $5 \%$ SDS (w/v), $30 \%$ glycerol (v/v)) containing $1 \%(\mathrm{w} / \mathrm{v})$ DTT, then in IEF equilibration buffer containing $2.5 \%$ iodoacetamide $(w / v)$. The second dimension electrophoresis was run on a $15 \%$ SDS gel. Gels were imaged using a Typhoon 9400 Imager (GE Healthcare) using excitation and emission wavelengths of $532 / 580 \mathrm{~nm}$. Images were quantified using ImageJ $1.48 \mathrm{~V}$.

\subsection{In-gel digestion and MS}

Bands were excised by hand and treated with trypsin as described elsewhere (Shevchenko et al., 2006). Tryptic digests were desalted on home-made C18 StageTips as described by Rappsilber et al. (2007). After elution from the StageTips samples were dried using a vacuum concentrator (Eppendorf) and the peptides were taken up in $10 \mu \mathrm{L}$ of $0.1 \%$ formic acid solution.

LC-MS/MS experiments were performed on an Orbitrap Elite instrument (Thermo, Michalski et al., 2012) that was coupled to an EASY-nLC 1000 liquid chromatography (LC) system (Thermo). The LC was operated in the two-column mode. The home-made fused silica column equipped with a glass fiber frit (Maiolica et al., 2005) was packed with ReprosilPur 120 C18-AQ $3 \mu \mathrm{m}$ resin (Dr. Maisch) and connected to the analytical column via an UHPLC union (Upchurch; UH-432). The analytical column was a fused silica capillary (75 $\mu \mathrm{m}$ $\times 25 \mathrm{~cm}$ ) with integrated PicoFrit emitter (New Objective) packed in-house with Reprosil-Pur 
$120 \mathrm{C18}-\mathrm{AQ} 3 \mu \mathrm{m}$ resin (Dr. Maisch). The analytical column was attached to a nanospray flex ion source (Thermo). The LC was equipped with two mobile phases: solvent $A(0.1 \%$ formic acid, FA, in UPLC grade water) and solvent $B(0.1 \%$ FA in acetonitrile, ACN). Peptides were delivered to the pre-column via the integrated autosampler at a flow rate of 2 - $3 \mu \mathrm{l} / \mathrm{min}$ in $100 \%$ solvent $\mathrm{A}$. Peptides were subsequently separated on the analytical column by running a 70 min gradient of solvent $A$ and solvent $B$ (start with $7 \%$; gradient $7 \%$ to $35 \%$ B for $60 \mathrm{~min}$; gradient $35 \%$ to $100 \%$ B for $5 \mathrm{~min}$ and $100 \% \mathrm{~B}$ for $5 \mathrm{~min}$ ) at a flow rate of $300 \mathrm{nl} / \mathrm{min}$. The mass spectrometer was operated using Xcalibur software (version 2.2 SP1.48) and was set in the positive ion mode. Precursor ion scanning was performed in the Orbitrap analyzer (FTMS) in the scan range of $\mathrm{m} / \mathrm{z} 300-1,500$ and at a resolution of 120,000 with the internal lock mass option turned on (lock mass was $445.120025 \mathrm{~m} / \mathrm{z}$, polysiloxane) (Olsen et al., 2005). Product ion spectra were recorded in a data dependent fashion in the ion trap (ITMS) in a variable scan range and at a rapid scan rate. The ionization potential (spray voltage) was set to $1.6-2.0 \mathrm{kV}$. Peptides were analyzed using a repeating cycle consisting of a full precursor ion scan $\left(1.0 \times 10^{6}\right.$ ions $)$ followed by 15 product ion scans $(1.0 \times$ $10^{4}$ ions) where peptides are isolated based on their intensity in the full survey scan (threshold of 500 counts) for tandem mass spectrum (MS2) generation that permits peptide sequencing and identification. CID collision energy was set to $35 \%$ for the generation of MS2 spectra. During MS2 data acquisition dynamic ion exclusion was set to 120 seconds with a maximum list of excluded ions consisting of 500 members and a repeat count of one. Ion injection time prediction, preview mode for the FTMS, monoisotopic precursor selection and charge state screening were enabled. Only charge states bigger than 1 were considered for fragmentation.

\subsection{Peptide and Protein Identification}

The recorded RAW files were processed in ProteomDiscoverer 1.4 (PD14, Thermo). MS2 spectra were extracted using the Spectrum Selector node. Precursor selection was set to "use MS1 precursor". The mass range was set between 350 - 5,000 Da with a minimum peak count of 1 . Mass analyzer was set to "any" and MS order to "MS2". Activation type was set to "is CID" and Scan type was defined as "full" with ionization source set to "is nanospray". Selected spectra were submitted to the in house MASCOT server (version 2.4.1 (Perkins et al., 1999)) using the PD14 MASCOT node. Alternatively, RAW spectra were submitted to an Andromeda (Cox et al., 2011) search in MaxQuant (version 1.5.0.25) using the default settings (Cox et al., 2005). Label-free quantification and match-between-runs was activated (Cox et al., 2014). 
MS2 spectra data were searched against the tomato_ITAG.fasta database (solgenomics.net; version 2.3; 34725 entries). All searches included a contaminants database (as implemented in MASCOT and MaxQuant, 263 sequences). The contaminants database contains known MS contaminants and was included to estimate the level of contamination. Mascot and Andromeda searches allowed for oxidation of methionine residues (16 Da) and a static modification on cysteine (57 Da, alkylation with iodoacetamide). Enzyme specificity was set to Trypsin/P. The instrument type in MASCOT searches was set to ESI-TRAP and the mass tolerance was set to $\pm 10 \mathrm{ppm}$ for precursor mass and $\pm 0.35 \mathrm{Da}$ for product ion masses. MS2 spectra matches were then evaluated using the peptide validation node of PD14 with the standard settings (search against decoy database, target false discovery rate (FDR, strict): 0.01 and target FDR (released): 0.05). The reported results were further filtered. On peptide level only peptides with a minimum confidence 'medium' were reported and on protein level only proteins with a minimum of at least two peptide hits were reported. For the Andromeda searches the default MaxQuant settings were used. Briefly, the precursor peptide tolerance for the first search was $20 \mathrm{ppm}$ and for the main search $4.5 \mathrm{ppm}$. The ion trap MS/MS match tolerance was $0.5 \mathrm{Da}$. Label-free quantification and match-between-runs was switched on. All other settings were comparable to the MASCOT search.

\subsection{PNGaseF Treatment of Labeled Proteins}

$9 \mu \mathrm{l}$ of MVB072-labelled tomato root extract and Bovine Fetuin (Promega) were treated with $1 \mu \mathrm{l}$ of $10 \mathrm{X}$ glycoprotein denaturing buffer (New England BioLabs) and heated at $95^{\circ} \mathrm{C}$ for 5 minutes. The denatured proteins were chilled on ice. $2 \mu$ 10X GlycoBuffer (New England BioLabs), $2 \mu \mathrm{l} 10 \% \mathrm{NP} 40$ (Promega) and $6 \mu \mathrm{l} \mathrm{H}_{2} \mathrm{O}$ was added to the reaction. The mixture was treated with $1 \mu \mathrm{l}$ PNGase $F$ (New England BioLabs) or with $1 \mu \mathrm{H}_{2} \mathrm{O}$ and incubated at $37^{\circ} \mathrm{C}$ for $1 \mathrm{~h}$. Samples were analyzed on $16 \%$ SDS-PAGE.

\subsection{Protein Deglycosylation of Labeled Proteins}

$18 \mu \mathrm{l}$ of MVB072-labelled sample and Bovine Fetuin (Promega) were treated with $2 \mu \mathrm{l}$ of $10 \mathrm{X}$ denaturing solution (Promega) and heated at $95^{\circ} \mathrm{C}$ for 10 minutes. The denatured proteins were chilled on ice for $5 \mathrm{~min}$. To the denatured samples $5 \mu \mathrm{l}$ of $10 \mathrm{X}$ Deglycosylation Reaction Buffer (Promega), $5 \mu$ l of $10 \%$ NP40 (Promega) and $15 \mu$ l of water were added. Samples were treated with $5 \mu$ l of Protein Deglycosylation Mix (Promega - PNGase F, OGlycosidase, Neuraminidase, $\beta 1-4$ Galactosidase, $\beta-N-A c e t y l g l u c o s a m i n i d a s e)$ and incubated at $37^{\circ} \mathrm{C}$ for $8 \mathrm{~h}$. Samples were analyzed on $16 \%$ SDS-PAGE. 


\subsection{Protein Phosphatase treatment}

$60 \mu \mathrm{l}$ of MVB072-labelled sample containing $1 \mathrm{M} \mathrm{NaCl}, 25 \mathrm{mM} \mathrm{MgCl} 210 \mathrm{mM}$ DTT and 12.5X protease inhibitor cocktail (Sigma) were treated with 1 or $5 \mu$ l of alkaline phosphatase (Sigma P0114) and incubated at $37^{\circ} \mathrm{C}$ for $1 \mathrm{~h}$. Samples were analyzed on 16\% SDS-PAGE, whereas the remainder of the sample were separated on 10\% SDS-PAGE and transferred to polyvinylidene difluoride (PVDF) membrane for detection of phosphorylated MAPK using primary antibody, Phospho-p44/42 MAPK (Erk1/2) (Thr202/Tyr204) antibody (CST, \#9101) and secondary Goat anti-Rabbit IgG (Thermo, \#31466) and visualized using chemiluminescent substrates (SuperSignal West/Pico Chemiluminescent substrates, Thermo scientific).

\subsection{Bioinformatics}

Genes encoding the $\beta$ subunits of tomato were identified by BLASTp searches of the predicted proteome (ITAG release 2.40) for homologs of the seven Arabidopsis $\beta$ subunits at the SolGenomics website (www.solgenomics.net). The $\beta 2 a$ protein sequence was modeled onto polypeptide $\mathrm{H}$ of the structure of the yeast proteasome (2zcy, Groll et al., 2008) using Swiss Model (swissmodel.expasy.org, Biasini et al., 2014). This $\beta 2 a$ model was used in PyMol to replace the $\beta 2$ in the structure of the yeast proteasome. Only the surface of one ring of $\beta$ subunits was visualized and the various parts and residues were colored using PyMol. Further annotations were added using CoreIDRAW. Transcript levels were extracted from published RNA sequencing experiments on different organs (The Tomato Genome Consortium, 2012).

\subsection{Statistics}

Results are expressed as mean \pm SE. Statistical analysis was performed with GraphPad using Student's t-test ( ${ }^{\star}$ P B 0.05, ${ }^{* *}$ P B 0.01, ${ }^{* \star *}$ P B 0.001). 


\section{Results}

To investigate the activities of proteases in salt stress-induced PCD in tomato, plants were treated with sublethal- $(100 \mathrm{mM})$ and lethal $(250 \mathrm{mM})$ concentrations of $\mathrm{NaCl}$ (Fig.11).

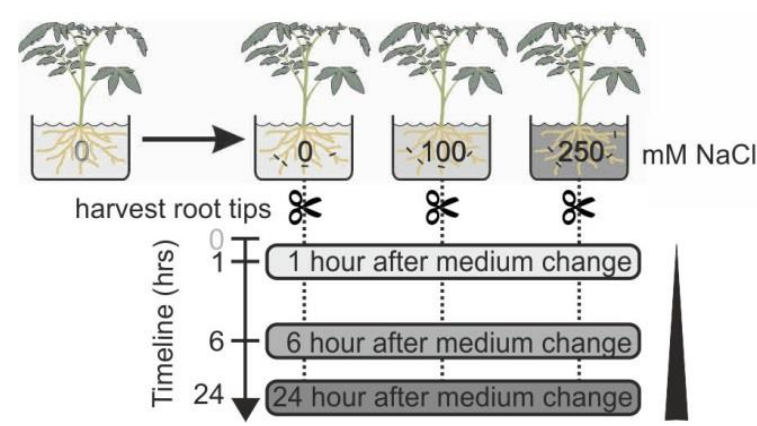

Figure 11 Experimental design to study the effects of salt stress in tomato roots. Tomato (Solanum lycopersicum) plants were grown in a hydroponic system. 5-week-old plants were treated with 0,100 and $250 \mathrm{mM} \mathrm{NaCl}$ in the nutrient solution and root tips were collected at 1,6 and $24 \mathrm{~h}$. Black triangle indicates the intensity of salinity effect.

\subsection{Detection of cell viability}

\subsubsection{FDA staining}

We studied the early stages of PCD by collecting samples at 1, 6 and 24 hours after salt exposure. Root tips were stained with fluorescein diacetate (FDA) to detect and quantify viable cells. Low FDA staining after 6 hours upon $250 \mathrm{mM} \mathrm{NaCl}$ treatment indicates a massive and quick loss of viability and a possible initiation of PCD that is completed within 24 hours (Fig.12AB). By contrast, treatment with $100 \mathrm{mM} \mathrm{NaCl}$ causes a slower loss of viability, where decreased viability is detected only at 24 hours. 


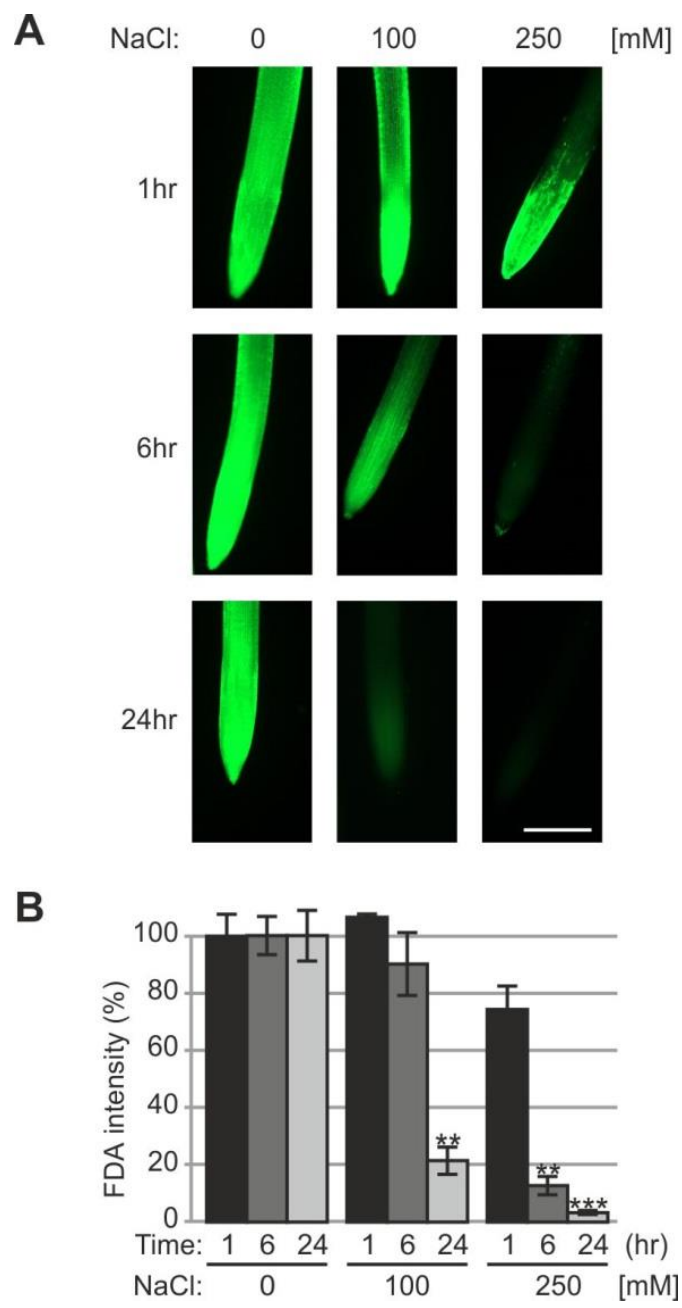

Figure 12 Representative images in cell viability of 0,100 and $250 \mathrm{mM} \mathrm{NaCl}$ treated roots. Root tips were stained with FDA to detect the viable cells. Scale bar is $0.5 \mathrm{~mm}$. (B) Fluorescent intensities of FDA fluorescence levels compared to the control. Error bars represent SEM of $\mathrm{n}=3$ biological replicates. (Means are significant at $\mathrm{P}<0.5\left(^{*}\right) ; 0.01\left(^{* *}\right)$ or $\left.0.001{ }^{* * *}\right)$ level as determined by Student's t-test).

\subsubsection{Electrolyte leakage and elemental analysis}

Alteration of membrane integrity was monitored both in tomato leaves and roots upon sublethal- and lethal salt treatment after 1, 6 and 24 hours (Fig.13AB). High electrolyte leakage (EL) after 1 hour from the samples treated with $250 \mathrm{mM} \mathrm{NaCl}$ indicates a massive ion efflux which after 24 hours becomes irreversible in the roots. Lethal salt stress significantly increases EL in the leaves, however, it remains reversible. Sublethal salt treatment does not significantly affect the ion efflux when compared to the control.

Since ion contents, especially those of $\mathrm{K}^{+}$and $\mathrm{Na}^{+}$characterize the severity of salt stress as well as the decrease of $\mathrm{K}^{+}$refers to the putative activation of cysteine proteases, we also determined the ion content of organs (Table 1). 


\begin{tabular}{lcccccc}
\hline \multirow{2}{*}{$\begin{array}{l}\text { Elements } \\
\left(\mu \mathrm{mol} \mathrm{gDW}^{-}\right.\end{array}$} & \multicolumn{2}{c}{ Control } & \multicolumn{2}{c}{ Treatments } \\
\cline { 2 - 6 } & \multicolumn{2}{c}{$100 \mathrm{mM} \mathrm{NaCl}$} & \multicolumn{2}{c}{$250 \mathrm{mM} \mathrm{NaCl}$} \\
\cline { 2 - 6 } & Leaves & Roots & Leaves & Roots & Leaves & Roots \\
\hline $\mathrm{K}^{+}$ & $725.70+0.14$ & $1205.48+12.26$ & $714.94+2.69^{* *}$ & $664.24+2.95^{* * *}$ & $652.82+1.66^{* * * *}$ & $266.91+1.02^{* * * *}$ \\
$\mathrm{Na}^{+}$ & $14.98+0.06$ & $341.89+4.14$ & $52.51+0.20^{* * *}$ & $1085.40+7.20^{* * * *}$ & $987.24+4.40^{* * * *}$ & $1471.23+2.23^{* * * *}$ \\
$\mathrm{~K}^{+} / \mathrm{Na}^{+}$ & $48.42+0.22$ & $3.52+0.0^{a}$ & $13.60+0.03^{* * *}$ & $0.61+0.01^{* * *}$ & $0.66+0.01^{* * *}$ & $0.18+0.01^{* * * *}$ \\
\hline
\end{tabular}

Table $1 \quad$ Changes in the intracellular $\mathrm{K}^{+}$and $\mathrm{Na}^{+}$contents and the $\mathrm{K}^{+} / \mathrm{Na}^{+}$ratio in the leaves and roots of tomato plants after exposure to 100 or $250 \mathrm{mM} \mathrm{NaCl}$ for 24 hours. (Means $\pm \mathrm{SD}, \mathrm{n}=6$ ). ${ }^{*},{ }^{* *},{ }^{* * *}$ indicate significance levels compared to the untreated control at $P<0.05,0.01,0.001$.

$\mathrm{K}^{+}$dramatically drops, especially in roots causes 5 -fold change upon lethal salt stress whereas $\mathrm{Na}^{+}$enters to the cells which clearly reduce the $\mathrm{K}^{+} / \mathrm{Na}^{+}$ratio in both organs after 24 hours. In contrast, sublethal salt treatment does not have significant effect on $\mathrm{K}^{+}$content in leaf tissue and $\mathrm{Na}^{+}$slowly increases which indicates a reduced $\mathrm{K}^{+} / \mathrm{Na}^{+}$ratio (Table 1).

A

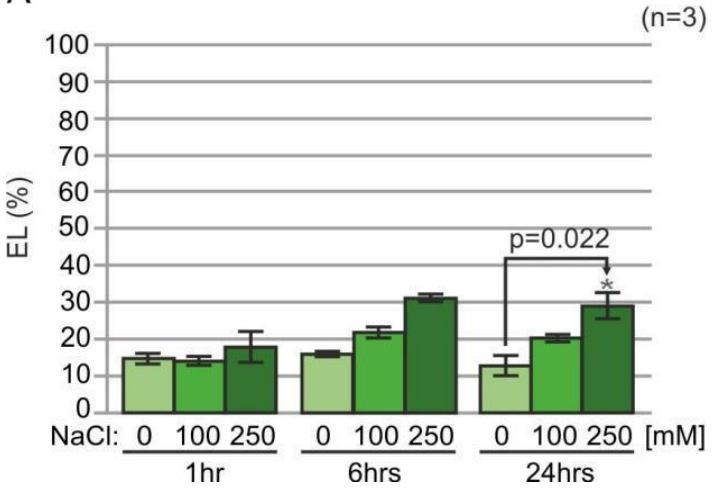

B

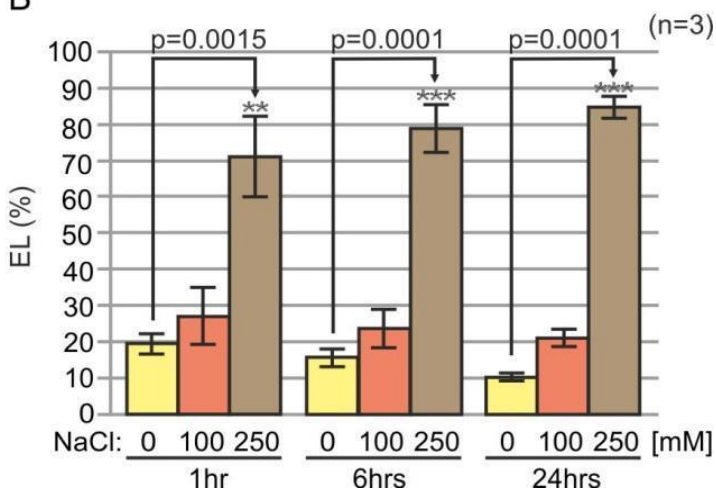

Figure 13 Alteration of membrane integrity in tomato leaves $(\mathbf{A})$ and roots $(\mathbf{B})$ upon 0 , 100 and $250 \mathrm{mM} \mathrm{NaCl}$ treatment after 1, 6 and 24 hours. Error bars represent SEM of $n=3$ biological replicates. (Means are significant at $\mathrm{P}<0.5\left(^{*}\right) ; 0.01\left(^{* *}\right)$ or $0.001\left(^{* * *}\right)$ level as determined by Student's t-test).

The result of $\mathrm{EL}$ shows that at $250 \mathrm{mM} \mathrm{NaCl}$ the disintegration of root cell membranes begins after one our of the stress and reaches irreversible (70-80\%) level. This suggests that the cell death is initiated very quickly after salt exposure in these organs.

\subsubsection{Detection of ROS and NO}

\subsubsection{Total ROS content}

We detected excessive level of ROS after 1 hour upon $250 \mathrm{mM} \mathrm{NaCl}$ treatment and significantly increased ROS after 6 hours upon both 100- and $250 \mathrm{mM} \mathrm{NaCl}$ treatment but after 24 hours ROS levels remain similar to the control in tomato leaves (Fig.14A). Dramatic increment is detected after 1 hour upon both salt treatments in root tips that is significantly decreased after 24 hours upon lethal salt stress compared to the control condition (Fig.14B). 

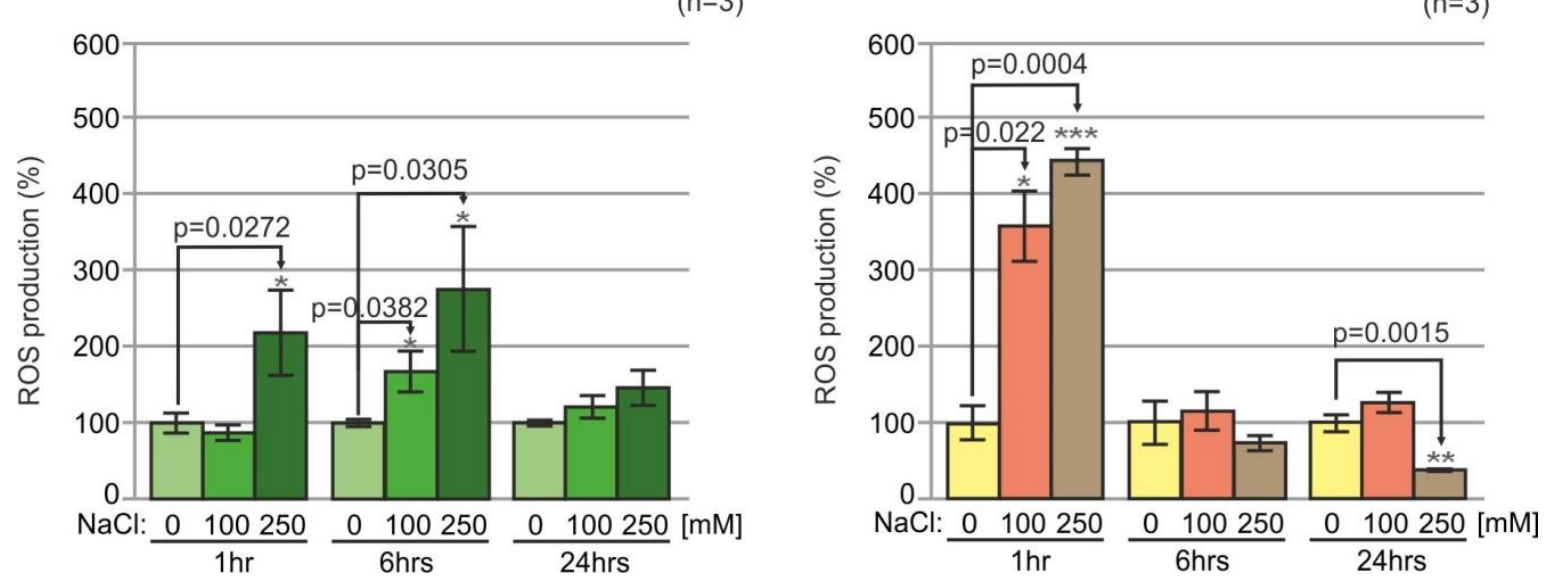

Figure 14 ROS generation in tomato leaves $(\mathbf{A})$ and roots $(\mathbf{B})$ upon 0,100 and $250 \mathrm{mM}$ $\mathrm{NaCl}$ after 1, 6 and 24 hours. Error bars represent SEM of $n=3$ biological replicates. (Means are significant at $\mathrm{P}<0.5\left(^{*}\right) ; 0.01\left(^{* *}\right)$ or $0.001\left(^{(* *}\right)$ level as determined by Student's t-test).

\subsubsection{2 $\mathrm{H}_{2} \mathrm{O}_{2}$ content}

Significantly increased $\mathrm{H}_{2} \mathrm{O}_{2}$ content is detected after 6 hours in leaves (Fig.15A), by contrast, it decreases after 24 hours in root tips upon lethal salt stress (Fig.15B). Sublethal salt treatment has no significant effect on $\mathrm{H}_{2} \mathrm{O}_{2}$ level. Although, its content increases after 24 hours both upon control and stressed conditions probably due to the circadian effect and endogen $\mathrm{H}_{2} \mathrm{O}_{2}$ alteration. But it could be affected by the circumstance of the way of the treatment as the roots are oxigenated for a certain time.
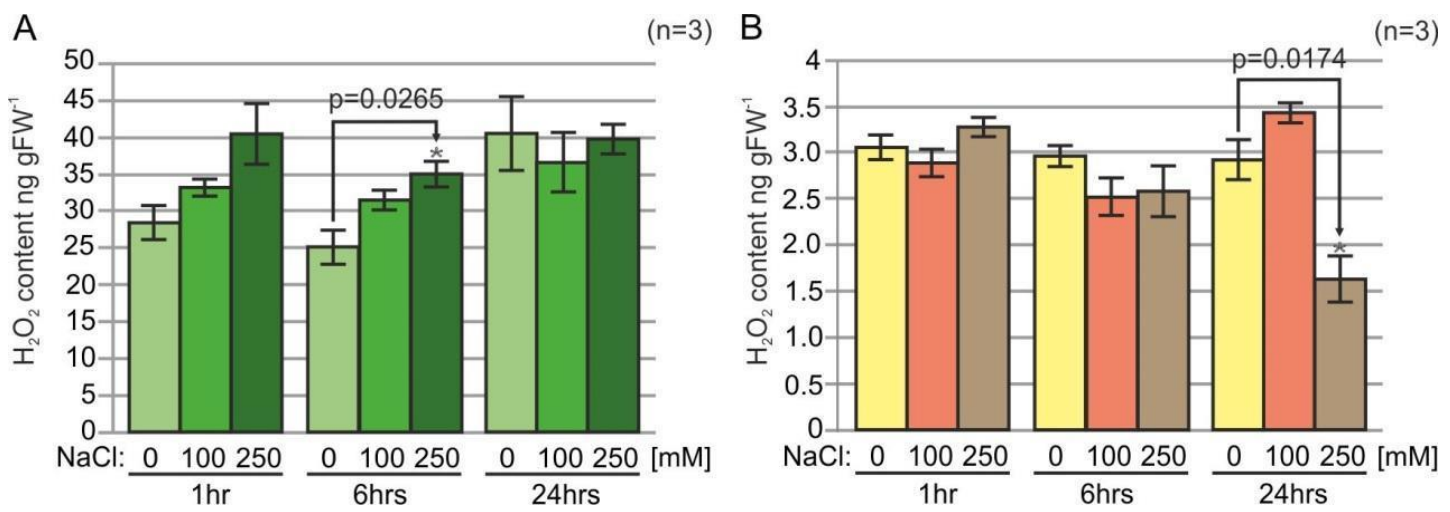

Figure $15 \quad \mathrm{H}_{2} \mathrm{O}_{2}$ content in tomato leaves $(\mathrm{A})$ and roots $(\mathrm{B})$ upon 0,100 and $250 \mathrm{mM}$ $\mathrm{NaCl}$ after 1, 6 and 24 hours. Error bars represent SEM of $n=3$ biological replicates. (Means are significant at $\mathrm{P}<0.5\left(^{*}\right) ; 0.01\left(^{* *}\right)$ or $0.001\left(^{(* *}\right)$ level as determined by Student's t-test). 


\subsubsection{NO content}

Elevated $\mathrm{NO}$ production is found after 6 hours upon $250 \mathrm{mM} \mathrm{NaCl}$ treatment and after 24 hours upon both 100 and $250 \mathrm{mM} \mathrm{NaCl}$ treatments in the leaves (Fig.16A). Importantly, NO level increases earlier in the root tips, after 1 hour upon high salt treatment and after 6 hours upon both 100- and $250 \mathrm{mM} \mathrm{NaCl}$ treatment which decreases after 24 hours (Fig.16B). Sublethal salt stress has delayed effect in both organs.
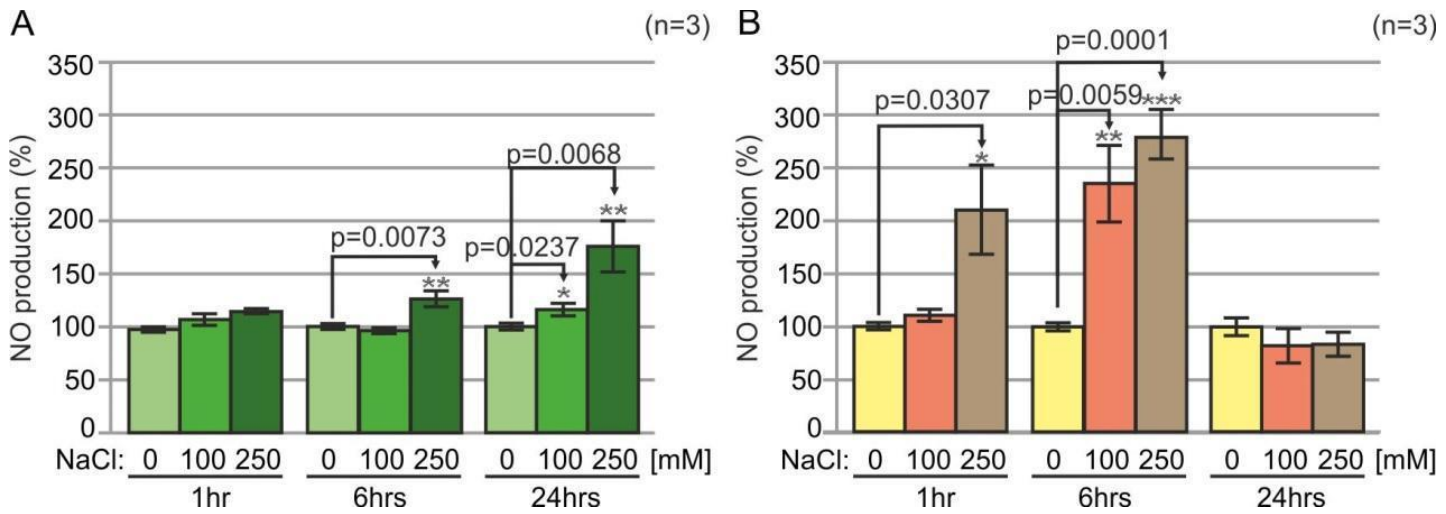

Figure 16 Kinetics of nitric oxide (NO) production in tomato leaves (A) and roots (B) upon 0, 100 and $250 \mathrm{mM} \mathrm{NaCl}$ after 1, 6 and 24 hours. Error bars represent SEM of $n=3$ biological replicates. (Means are significant at $\mathrm{P}<0.5\left(^{*}\right) ; 0.01\left(^{* *}\right)$ or $\left.0.001{ }^{* * *}\right)$ level as determined by Student's t-test).

\subsubsection{Investigation of protein degradation}

\subsubsection{Total protein content}

Total protein content is 2-fold less in the roots compared to the leaves (Fig.17). High salinity-induced decreasing tendency is observed after 6 hours in root tips and significant decrease is observed after 24 hours in both leaves and roots at $250 \mathrm{mM}$ concentration. 
A

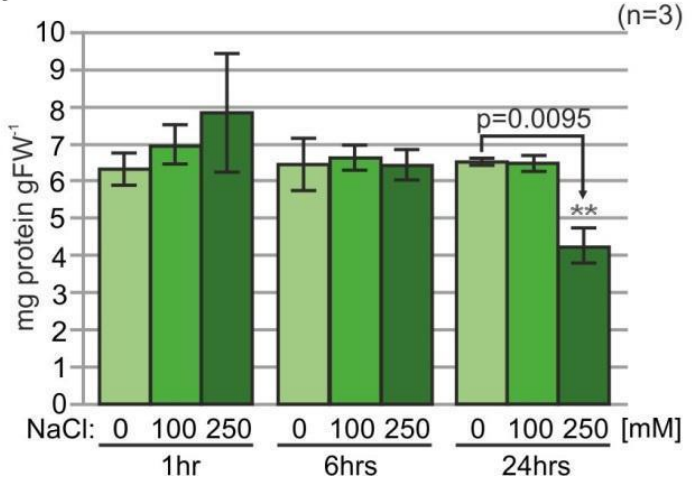

B

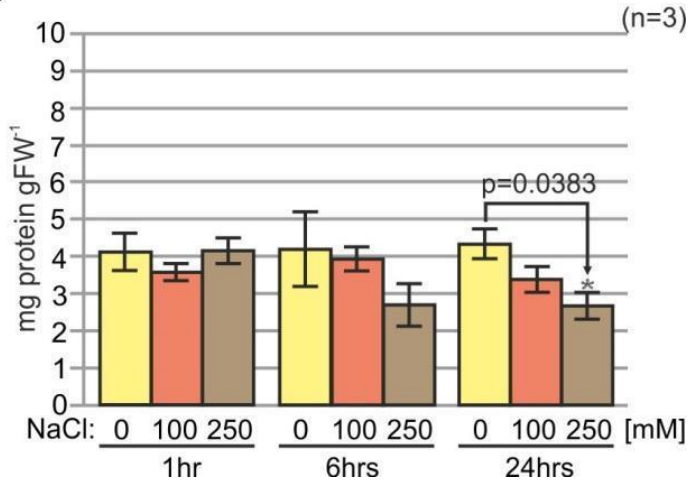

Figure 17 Total protein content in tomato leaves (A) and roots (B) upon 0, 100 and 250 $\mathrm{mM} \mathrm{NaCl}$ treatment after 1, 6 and 24 hours. Error bars represent SEM of $n=3$ biological replicates. (Means are significant at $\mathrm{P}<0.5\left({ }^{*}\right) ; 0.01\left(^{* *}\right)$ or $0.001\left(^{* * *}\right)$ level as determined by Student's t-test).

\subsubsection{Proteolytic activity}

\subsection{Azocaseinolytic assay}

To investigate proteolytic activity we utilized two different protease substrates, azocasein and gelatine, respectively. Azocaseinolytic assay revealed two- or three-fold higher proteolytic activity in the root tips compared to the leaves both in untreated and treated samples (Fig.18). High salt stress induces proteolysis after 6 hours in both organs which is accomplished after 24 hours. Sublethal salt treatment does not influence the azocaseinolytic activity.
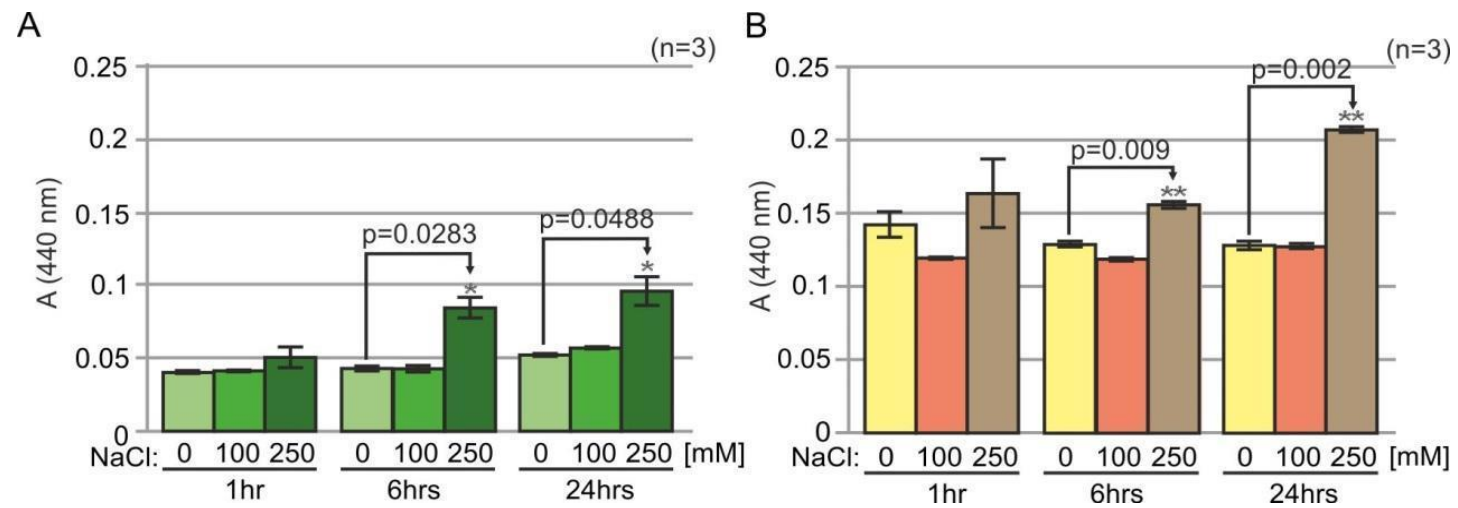

Figure 18 Azocaseinolytic activity in tomato leaves $(\mathbf{A})$ and roots $(\mathbf{B})$ extracts upon 0 , 100 and $250 \mathrm{mM} \mathrm{NaCl}$ treatment after 1, 6 and 24 hours. Error bars represent SEM of $\mathrm{n}=3$ biological replicates. (Means are significant at $\mathrm{P}<0.5\left(^{*}\right) ; 0.01\left(^{* *}\right)$ or $0.001\left(^{* * *}\right)$ level as determined by Student's t-test). 


\subsection{Zymography}

Proteases from the same samples were extracted and separated and their activities were quantified by gelatine-SDS-PAGE. Gelatine was added to SDS-PAGE, as protease substrate. After reactivation of different subsets of proteases and incubation in coomassie brilliant blue (CBB), white bands appeared on the gel by degrading gelatine (Fig.19A). Increasing tendency is noticed after 6 hour upon both sublethal and lethal salt treatments, moreover, signal intensity increased further upon lethal salt treatment by 24 hours (Fig.19B).

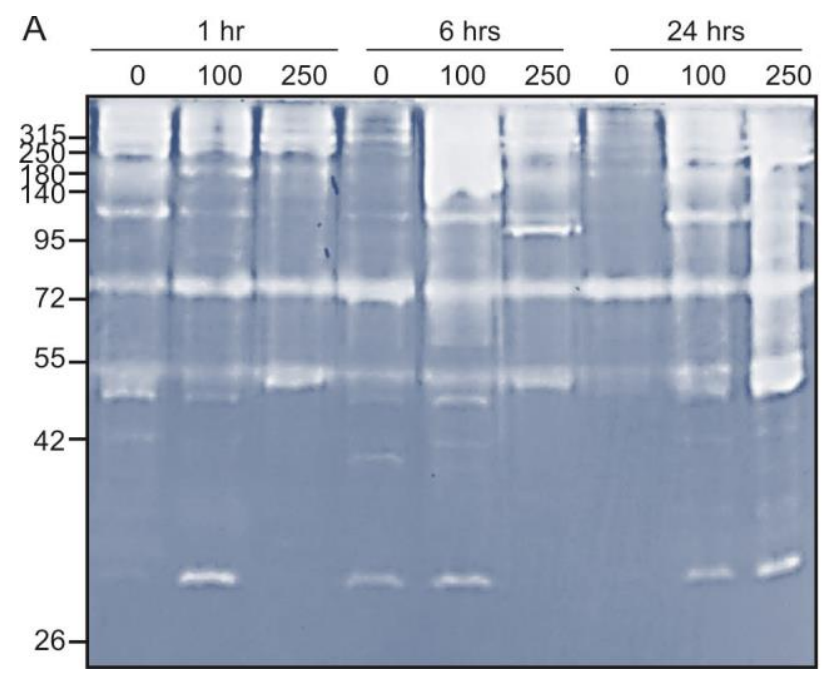

B

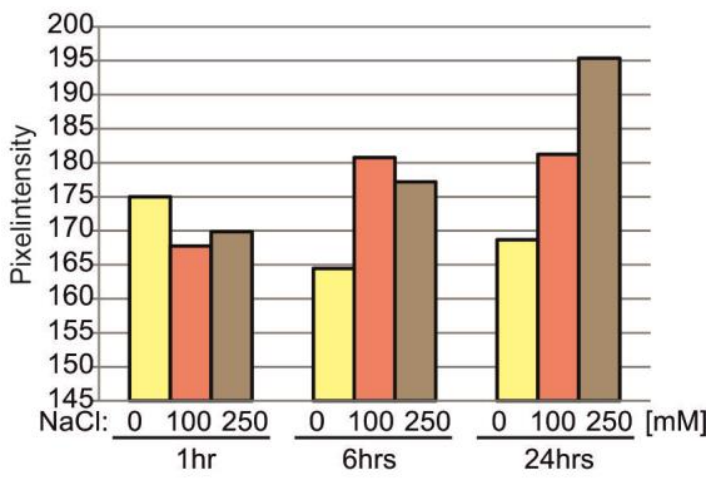

Figure 19 Protease activity on gelatine-SDS PAGE. (A) Protease activity in tomato roots upon 0, 100 and $250 \mathrm{mM} \mathrm{NaCl}$ treatment after 1, 6 and 24 hours on gelatine-SDS PAGE. (B) All white bands including all protease-like activity were quantified and summarized together over $\mathrm{n}=3$ biological replicates.

Focusing on the bands around 28- and $48 \mathrm{kDa}$ appear under control and sublethal salt conditions at the earlier stages and they are only detectable upon lethal salt treatment after 24 hours.

However, zymography is not sensitive enough to make differences between the protease subfamilies therefore we used activity-based protein profiling that is specific for several subsets of enzyme families.

\subsubsection{Investigation of Cys proteases and proteasome catalytic subunits using ABPP}

We applied activity-based protein profiling (ABPP) to investigate the alteration of activity profiles of several protease subfamilies during salt induced PCD, such as papain-like cysteine proteases (PLCPs), vacuolar processing enzymes (VPEs) and proteasome catalytic subunits $(\beta 1, \beta 2, \beta 5)$. 


\subsubsection{Cys proteases}

\subsection{Papain-like cysteine proteases (PLCPS)}

Activity of papain-like cysteine proteases (PLCPs) was monitored with ABPP using MV201, a fluorescent derivative of PLCP inhibitor, E-64 (Richau et al., 2012). To identify activated PLCPs after salt treatment, tissue extracts were labelled with DCG-04, a biotinylated version of MV201 (Greenbaum et al., 2000; Richau et al., 2012). Labelled proteins were purified on avidin beads, separated on $12 \%$ SDS gel and the $\sim 28 \mathrm{kDa}$ region was excised. We identified by mass spectrometry (MS) members of different PLCP subfamilies which could be activated upon salt stress. Furthermore, one set of identified PLCPs shows organ specificity, the other set is overlapping between the two studied, leaf and root.

To generate support that MV201 labels PLCPs, competition assay was performed using E-64. Signals were absent upon preincubation with an excess of E-64 as expected (Fig.20A, Fig.21B).

MV201 labeling profile uncovers three signals at different MW. There are double bands at $\sim 43-$, and $\sim 34 \mathrm{kDa}$ and single band at $\sim 28 \mathrm{kDa}$ in leaves (Fig.20A). Signals with higher MW are significantly reduced upon both salt treatments after 6 hours which are completed after 24 hours upon lethal salt stress in the leaves (Fig.20B).

By contrast, the lower, $28 \mathrm{kDa}$ signal is significantly increased upon lethal salt stress at 6 hours both in leaves and roots (Fig.20, Fig.21). In addition, the lower signal also appears at 24 hours upon sublethal treatment but signals at higher MW are not significantly altered upon salt treatment in the roots. 
A

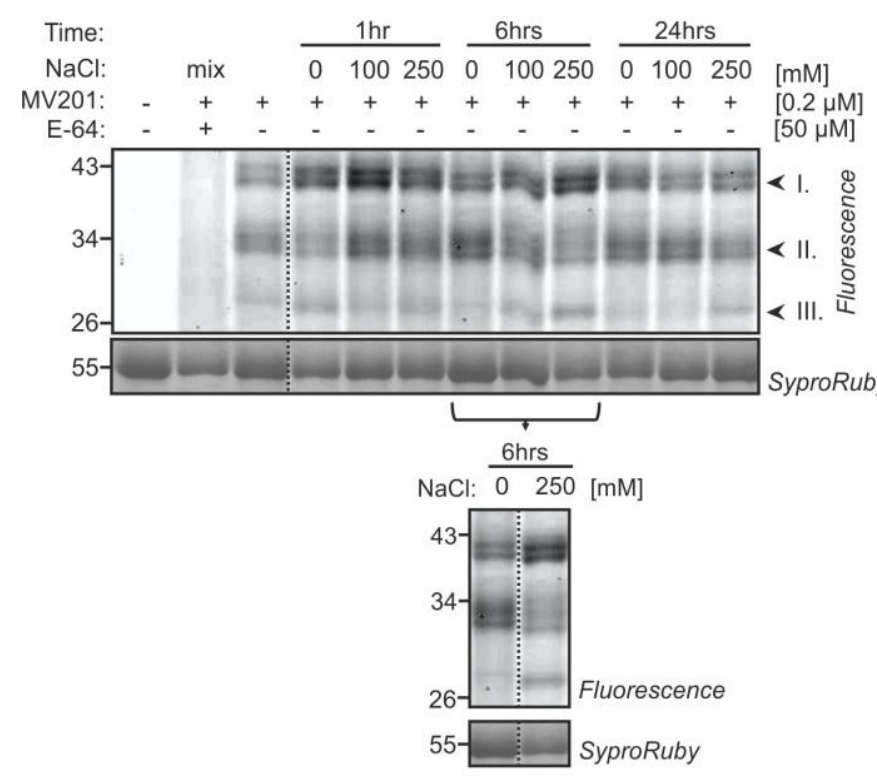

B

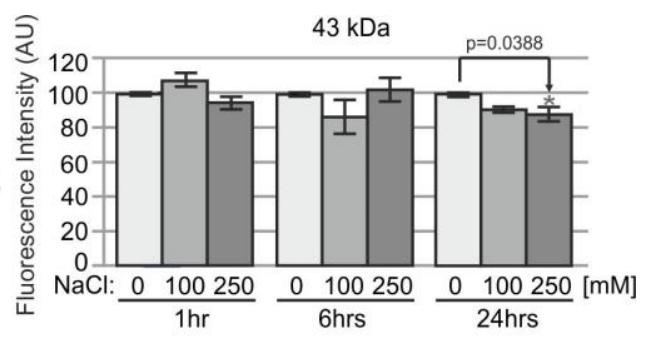

II.

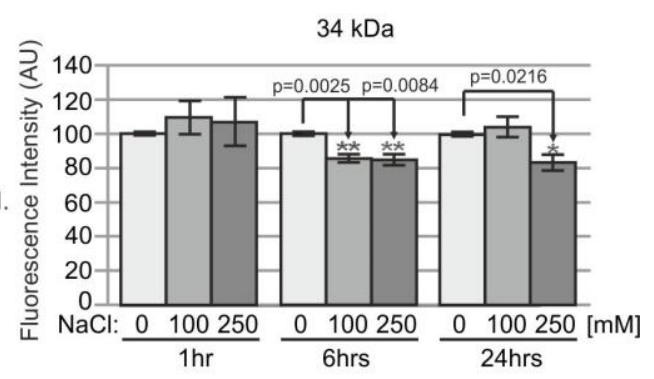

III.

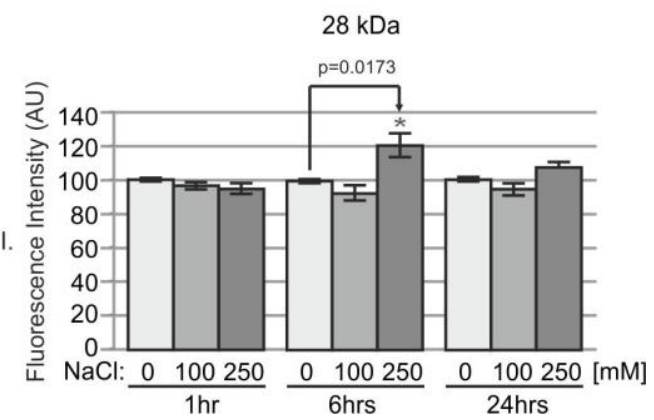

Figure 20 Salt stress in tomato leaves activates PLCPs. (A) Activation of PLCPs upon salt treatment after $1 \mathrm{~h}, 6 \mathrm{~h}$ and $24 \mathrm{~h}$. The black arrowheads indicate the three signals $\sim 43-$, 34- and $\sim 28 \mathrm{kDa}$ upon $250 \mathrm{mM} \mathrm{NaCl}$ treatments. (B) Quantification of the 43-, 34- and 28 $\mathrm{kDa}$ signals; over $\mathrm{n}=3$ biological replicates. (Means are significant at $\mathrm{P}<0.5\left(^{*}\right) ; 0.01\left(^{* *}\right)$ or $\left.0.001{ }^{* * *}\right)$ level as determined by Student's t-test).

Labeling of root extracts generated at 1 and 24 hours upon salt treatment demonstrates that the activation does not begin in the first hour, however, it can be detected from 6 hours and is sustained to 24 hours in roots (Fig.21A). The observed decreased activity upon control condition can be due to the normal circadian clock of PLCPs or their inhibitors.

To identify activated PLCPs after salt treatment, extracts were labelled with DCG-04, a biotinylated version of MV201 (Fig.22B, Fig.23B; Greenbaum et al., 2000; Richau et al., 2012). Labelled proteins were purified on avidin beads, separated on $12 \%$ SDS gel and the $\sim 28 \mathrm{kDa}$ region was excised. MS results revealed five PLCPs in leaves (Fig.22AC) and four PLCPs in roots (Fig.23AC). There are some overlaps between Solyc12g088670.1.1 (C14), an RD21A-like protease, Solyc04g080880.2.1, a XBCP3-like protease and Solyc07g041900.2.1 (CYP3), an aleurain-like protease were identified in both leaves and roots. 


\section{A}

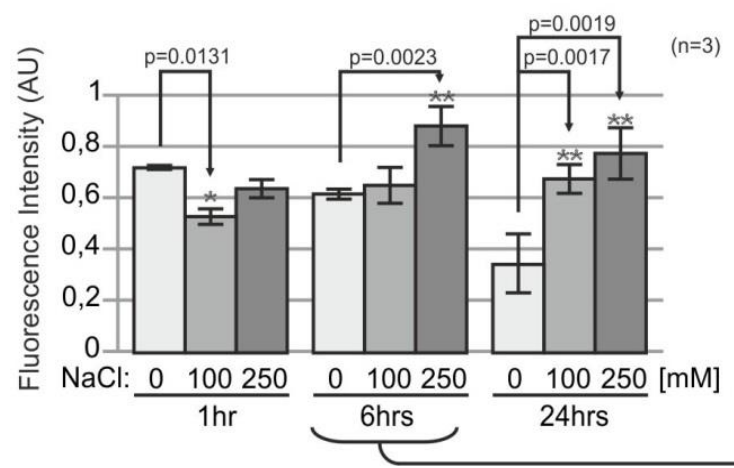

B

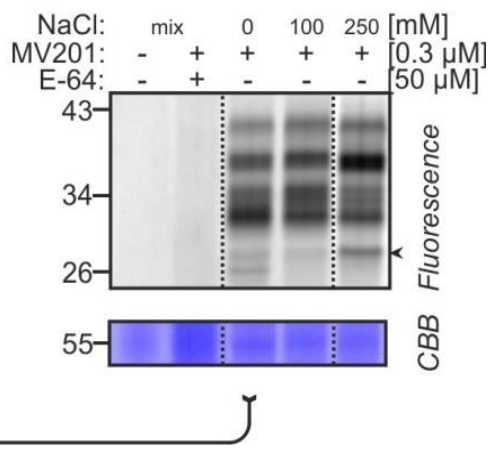

Figure 21 Salt stress in tomato roots activates papain-like Cys proteases. (A) Quantification of the $28 \mathrm{kDa}$ signal at different time points and salt treatments. Error bars represent SEM of $n=3$ biological replicates. (B) Differential MV201 labeling in samples from plants treated with various salt concentrations. Tomato roots were treated for 6 hours with 0 , 100 and $250 \mathrm{mM} \mathrm{NaCl}$. Root extracts were preincubated with or without E-64 and labeled with or without MV201. Consistent differential activity is highlighted (arrowhead). (Means are significant at $\mathrm{P}<0.5\left(^{*}\right) ; 0.01\left(^{* *}\right)$ or $0.001\left(^{* * *}\right)$ level as determined by Student's t-test).

However, we revealed some organ-specific induction. Lethal salt stress specifically induced Solyc04g080960.2.1 belonging to RD19A-like protease and Solyc02g077040.2.1 belonging to SAG12-like proteases in the leaves and Solyc04g078540.2.1, an RD21A-like protease in the roots, respectively.

A
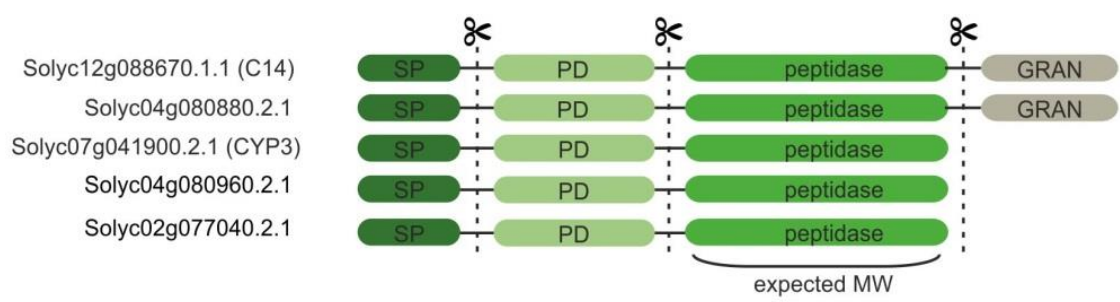

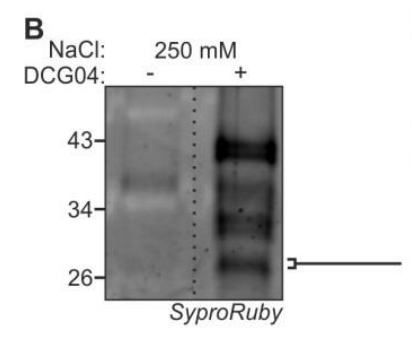

C

\begin{tabular}{|l|c|c|c|c|c|c|}
\hline Name & Subclassification & UP & ¿\# PSMs & Sequence Coverage & $\Sigma$ Score & MW \\
\hline Solyc12g088670.1.1 & RD21A & 7 & 9 & 16,74 & 139,46 & 51,10 \\
\hline Solyc04g080880.2.1 & XBCP3 & 4 & 7 & 6,27 & 302 & 95,70 \\
\hline Solyc07g041900.2.1 & AALP & 4 & 5 & 13,48 & 175,61 & 38,9 \\
\hline Solyc04g080960.2.1 & RD19A & 2 & 3 & 4,13 & 54,86 & 40,2 \\
\hline Solyc02g077040.2.1 & SAG12 & 2 & 2 & 12,46 & 57,08 & 38,20 \\
\hline
\end{tabular}

Figure 22 Identified proteins were classified into five different PLCP subclasses in tomato leaves (Richau et al. 2012). (A) Domain structure of identified PLCPs in tomato leaves. Signal peptide (SP), prodomain (PD) and granulin (GRAN) domain. (B) Purification of DCG04-labelled proteins from $250 \mathrm{mM} \mathrm{NaCl}$ treated samples and no-probe-control. Signal at $\sim 28 \mathrm{kDa}$ was excised and analyzed by MS. (C) MS data of identified proteins summarized are: number of detected unique peptides (UP); peptide spectral count ( $\sum \#$ PSMs); sequence coverage; protein score; and molecular weight (MW). 
PLCPs are synthesized as preproproteases that consist of a signal peptide (SP), autoinhibitory prodomain (PD) and the mature protease domain. The RD21A- and XBCP3like proteases carry an additional granulin-domain (GRAN) which can be removed during the maturation causing calculated signals at $\sim 30$ kDa (Fig.22A, Fig.23A; Yamada et al., 2001; Gu et al., 2013; Niemer et al., 2015).

Proteolysis has been well documented that is activated during PCD and is induced upon high salinity. Based on the domain structure and predicted MW of identified proteins in roots we anticipated that lethal salt stress might activate an aleurain-like protease, such as CYP3. To confirm the differential activity of aleurain-like proteases, we used an aleurainspecific fluorescent probe, FY01 (Lu et al., 2015). We only observed a faintly, but significantly up-regulated signal at $\sim 28 \mathrm{kDa}$ upon salt stress (Fig.S1). This is unlikely to represent greatly increased signal at $\sim 28 \mathrm{kDa}$ (Lu et al. 2015), raising the question whether a different PLCP might be the key role.

A
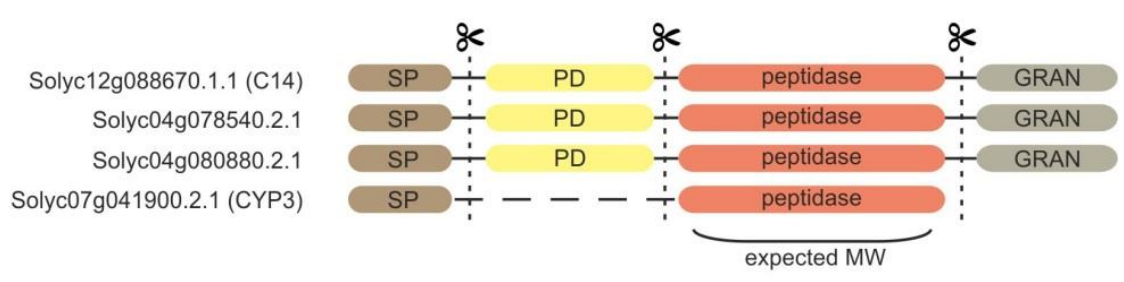

B

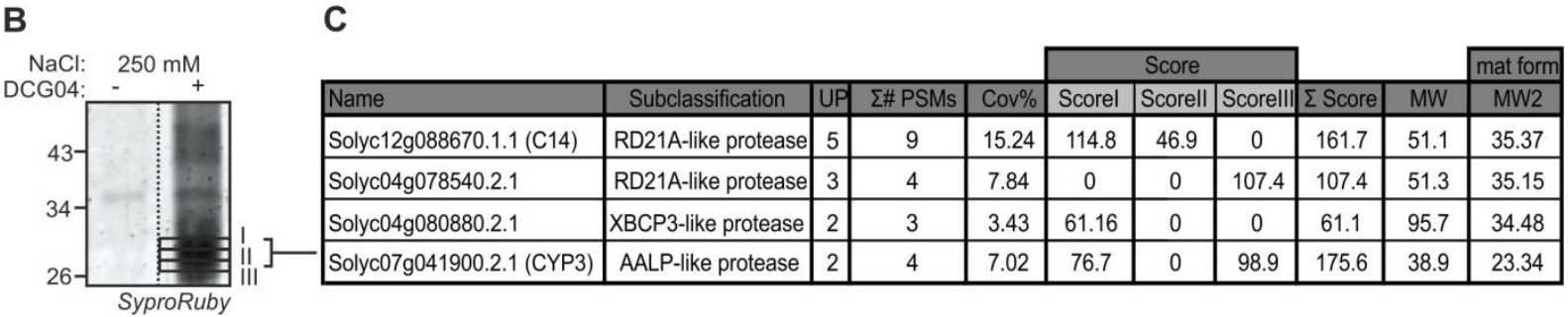

Figure 23 Identified proteins were classified into three different PLCP subclasses in tomato roots (Richau et al. 2012). (A) Domain structure of identified PLCPs in tomato roots. Signal peptide (SP), prodomain (PD) and granulin (GRAN) domain. (B) Purification of DCG04-labelled proteins from $250 \mathrm{mM} \mathrm{NaCl}$ treated samples and no-probe-control. Three framed areas at $\sim 28 \mathrm{kDa}$ were excised and analyzed by MS. (C) MS data of identified proteins summarized are: number of detected unique peptides (UP); peptide spectral count (PSM); sequence coverage (Cov\%); protein scores in samples (I, II, III) and molecular weight (MW) of preproteins and mature (mat) proteins.

\subsection{Expression level of papain-like cysteine proteases (PLCPS)}

We monitored the gene expression level of the identified PLCPs both in leaves and roots. PLCPs from subfamily of AALP-like, XBCP3-like and RD21A-like proteases (called as C14) were identified in both leaves and roots and PLCPs from RD19A-like and SAG12-like protease subfamily were specific to leaves and a second PLCP from RD21A-like subfamily was specific to roots. AALP, C14, RD19A and SAG12 were overexpressed in leaves upon 
$250 \mathrm{mM} \mathrm{NaCl}$ treatment after 24 hours (Fig.24). Amongs them AALP and RD19A are already upregulated at 6 hours upon lethal salt treatment in leaves. Although, C14 and SAG12 show overexpression upon lower salt treatment but they have got high standard deviation.

In roots, expression of RD21A-like PLCP is highly increased after 24 hours. C14 is slightly overexpressed after 1 hour in both salt treatments which decreased only upon sublethal condition and remained elevated upon lethal salt stress after 6 hours, too. Expression of root-specific $R D 21$ increased upon $250 \mathrm{mM} \mathrm{NaCl}$ treatment only after 24 hours (Fig.24). 
LEAF

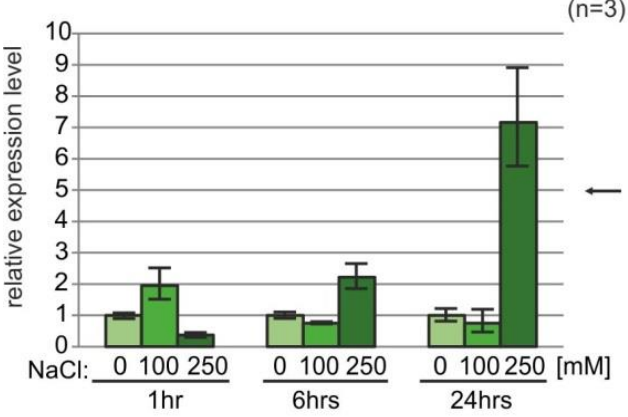

$(n=3)$

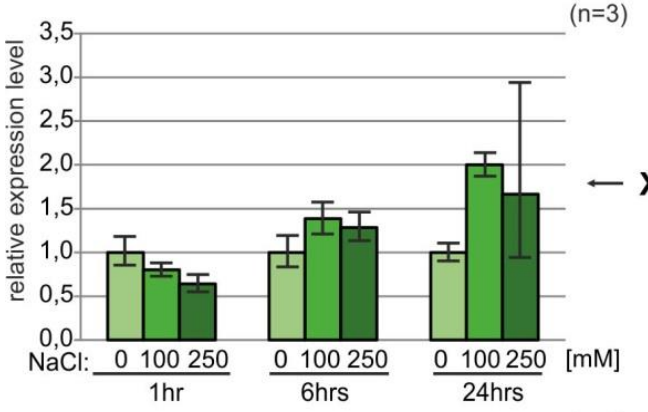

$(n=3)$

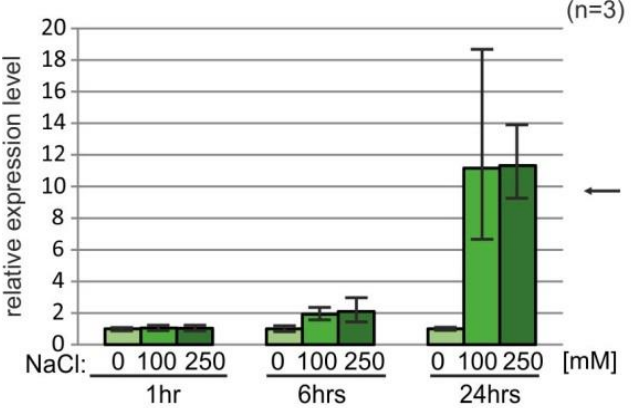

RD19A

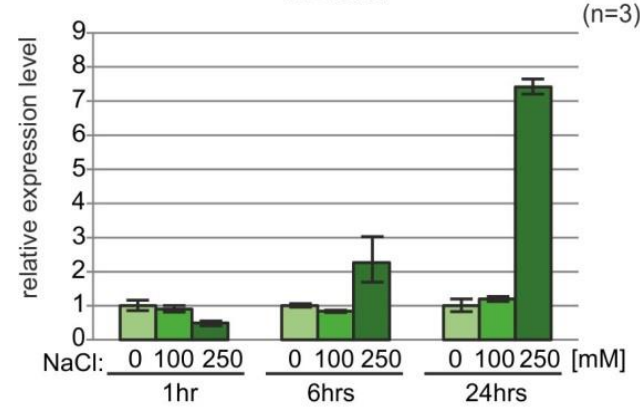

SAG12

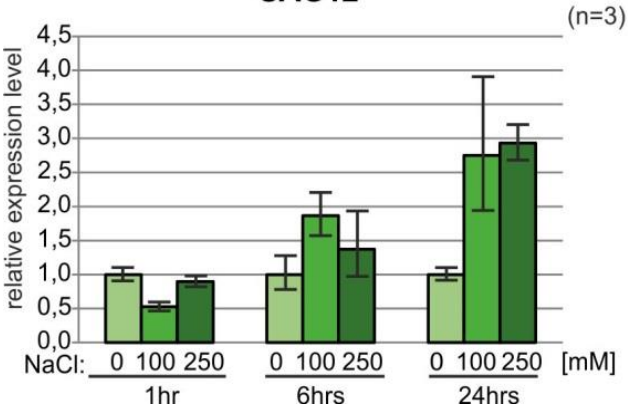

Figure 24 Relative expression level of the genes encoding the identified PLCPs in the leaves and root tissues of tomato. Tomato roots were treated with 0,100 and $250 \mathrm{mM} \mathrm{NaCl}$.
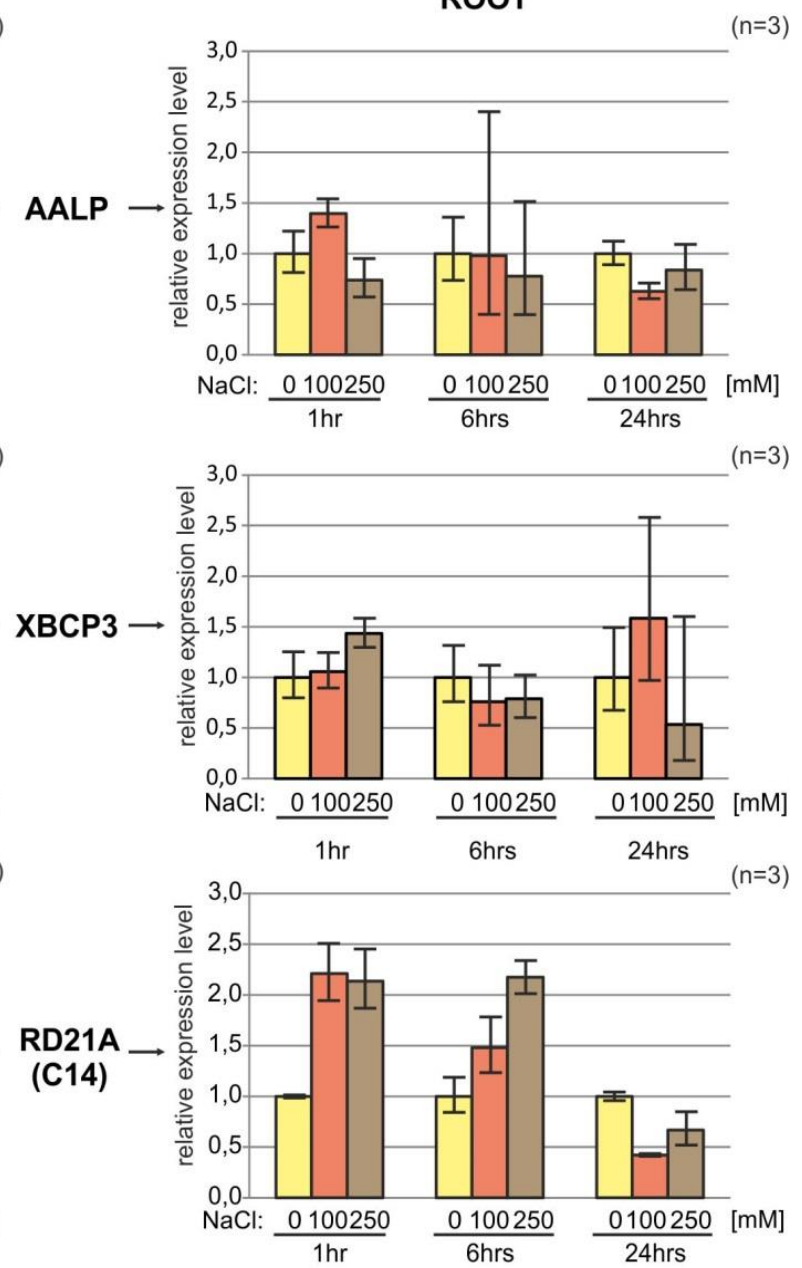

RD21A

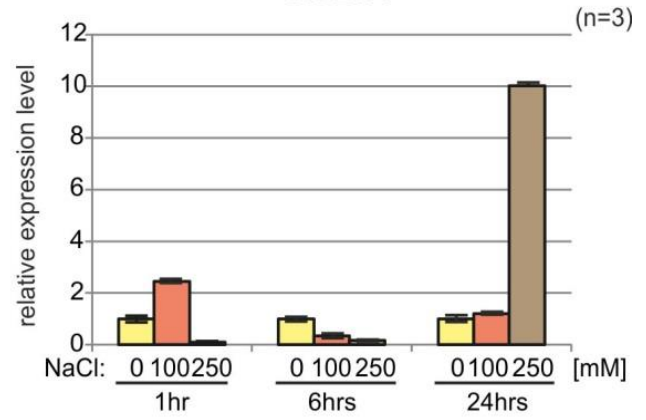

$(n=3)$ 


\subsubsection{Vacuolar processing enzymes (VPEs)}

To investigate the alteration of VPE profile, ABPP was applied using a bodipy version of the PD-AOMK probe, JOPD1. To improve and verify probe specificity different conditions were performed (Fig.25). Labelling of VPEs required reducing agent (e.g. DTT) since labelling did not occur in the absence of DTT and it is also absent at neutral pH. Signals show an optimum intensity at acidic $\mathrm{pH}$ therefore $\mathrm{pH} 5.5$ was chosen for subsequent competition assay (Kuroyanagi et al., 2002; Sueldo et al., 2014). Pre-incubation with iodoacetamide (IAcAm), YVAD-CMK (tyrosyl-valylalanyl-aspartyl-chloromethylketone) which is a caspase-1 inhibitor and 1440 prevented labeling, but not with E-64. Taken together these data show strong evidence that JOPD labels only VPE indeed. Activity profile displays three signals similar to PLCPs at $\sim 26-, \sim 34$ and $\sim 43 \mathrm{kDa}$.

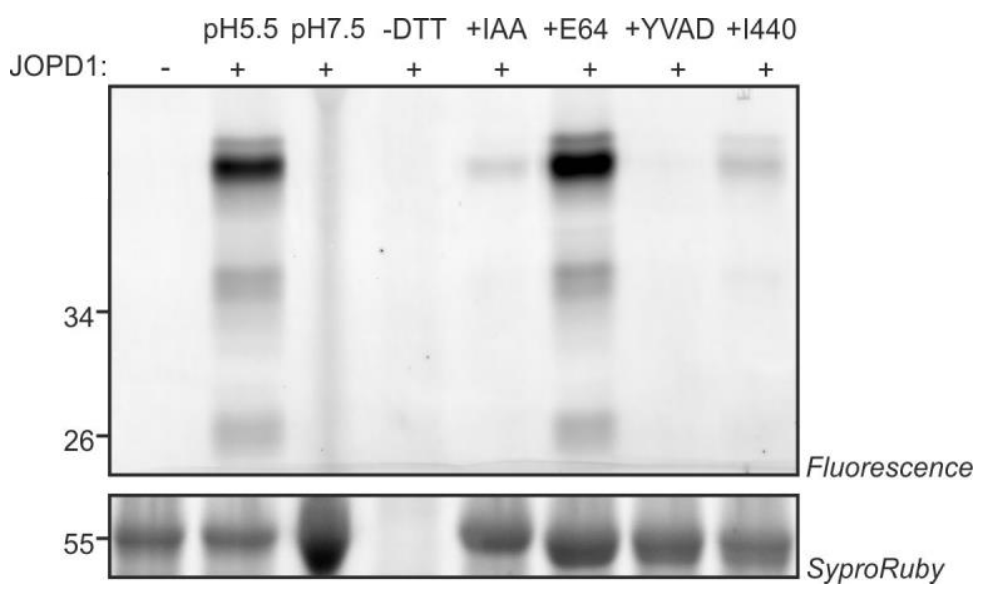

Figure 25 Characterization of JOPD labeling in tomato leaves treated with $250 \mathrm{mM} \mathrm{NaCl}$ in different labeling conditions: at pH 5.5 and pH 7.5, without DTT; with IcAmA; with E-64; with YVAD; with 1440.

Consistently, stronger VPE signals were detected upon high salt treatment after 6 hours in the leaves but not in the roots (Fig.26, Fig.27). 
A

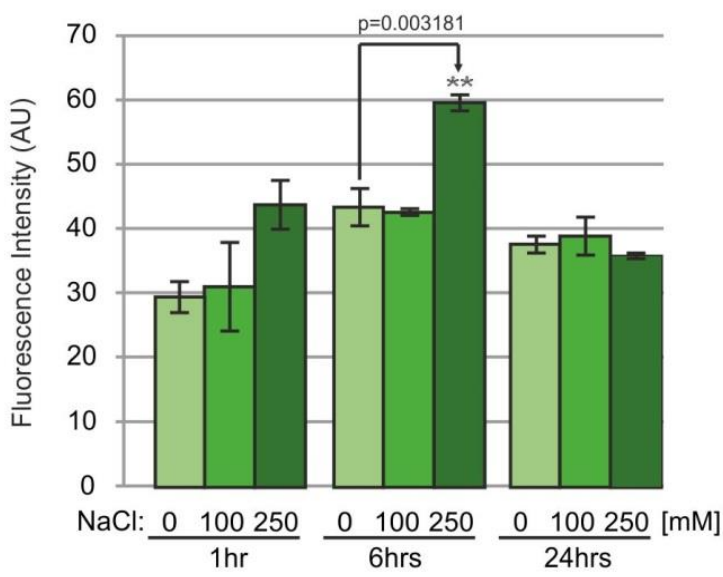

B
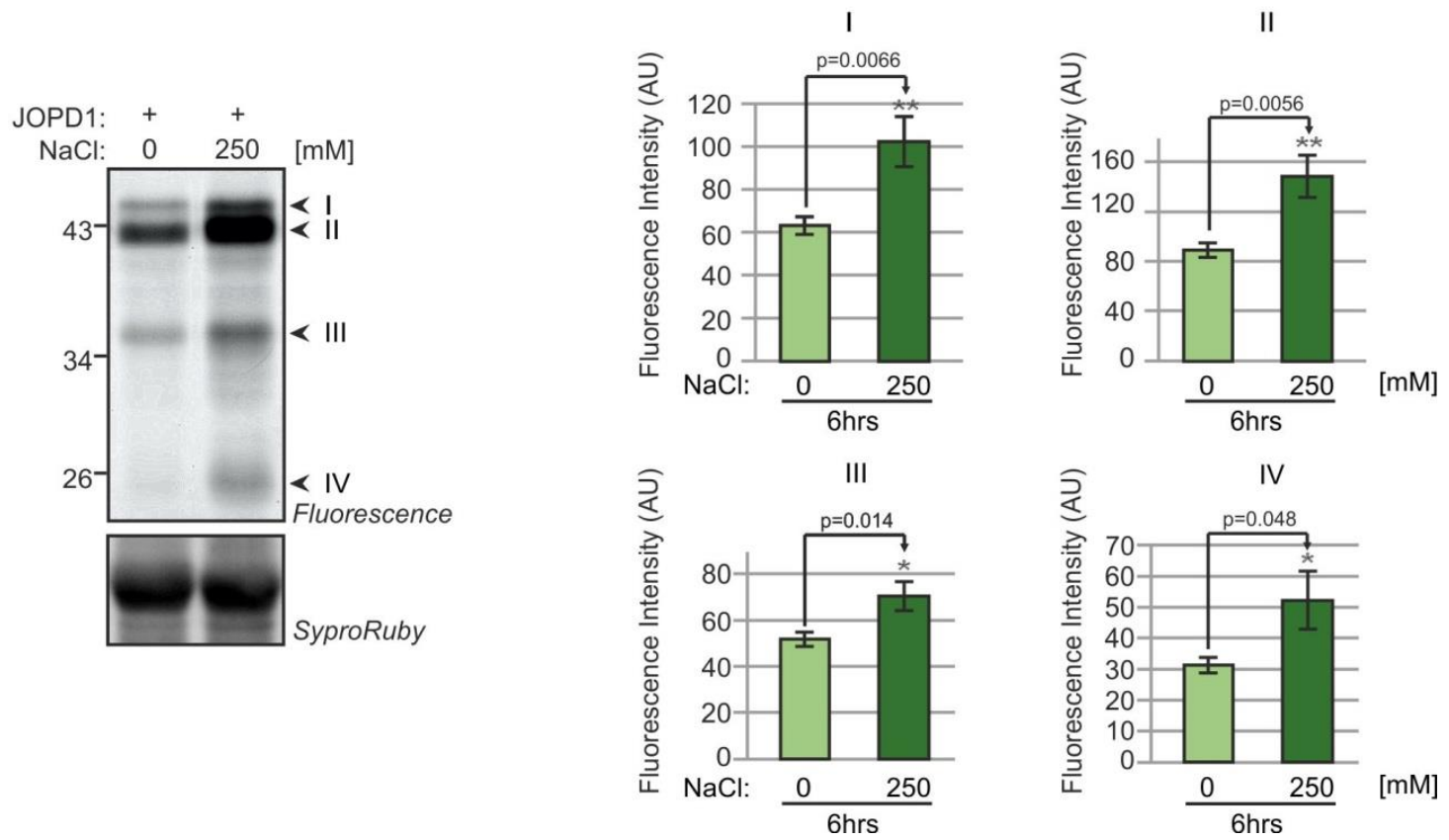

Figure 26 Lethal salt stress in tomato leaves activates VPE. (A) Quantification of the VPE signals at different time points and salt treatments. Error bars represent SEM of $n=3$ biological replicates. (B) Differential JOPD labeling in samples from plant leaf tissues treated with or without $250 \mathrm{mM} \mathrm{NaCl}$ for 6 hours. Consistent differential activity is highlighted (arrowhead). Error bars represent SEM of $n=3$ biological replicates. (Means are significant at $\left.\mathrm{P}<0.5\left(^{*}\right) ; 0.01{ }^{* *}\right)$ or $\left.0.001{ }^{* * *}\right)$ level as determined by Student's t-test).

By contrast, in roots signals are consistently weaker already after 1 hour upon $250 \mathrm{mM}$ $\mathrm{NaCl}$ treatment and persist until 24 hours. Low salt treatment increase the activity of VPEs afterwards display similar effect to control at 6 hours but it slightly decreases the enzyme activity after 24 hours (Fig.27B). 

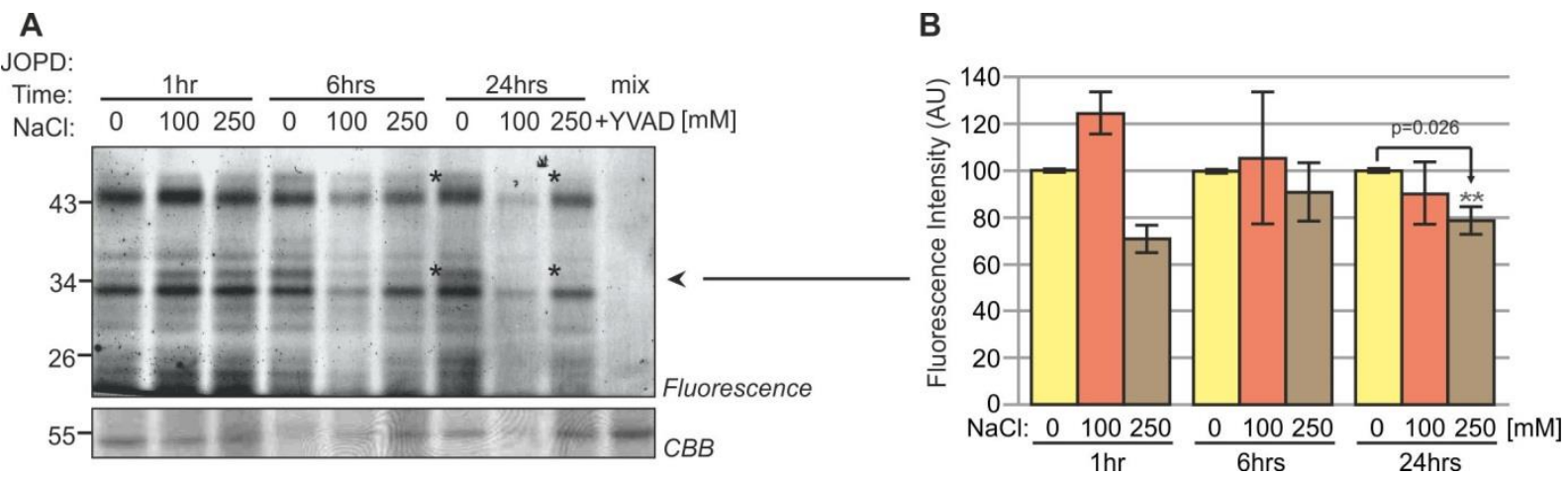

Figure 27 Salt stress in tomato roots deactivates VPE. (A) Labeling profile of VPE upon different salt treatments after $1 \mathrm{~h}, 6 \mathrm{~h}$ and $24 \mathrm{~h}$. The black arrowhead indicates a $34 \mathrm{kDa}$ signal treatment which is significantly weaker upon $250 \mathrm{mM} \mathrm{NaCl}$ compared to the control sample. (B) Quantification of the $34 \mathrm{kDa}$ signals at different time points and salt treatments. Error bars represent SEM of $\mathrm{n}=3$ biological replicates. (Means are significant at $\mathrm{P}<0.5\left(^{*}\right)$; $\left.0.01{ }^{* *}\right)$ or $\left.0.001{ }^{* * *}\right)$ level as determined by Student's t-test).

\subsubsection{Proteasome}

\subsection{Phylogenetic and structural analysis of $ß$ subunits}

Besides VPEs, $\beta 1$ catalytic subunit of the proteasome has caspase-3 activity, however, VPEs resemble the activity of caspase-1.

To investigate proteasome of tomato, we performed BLAST searches with the Arabidopsis $\beta$ subunits on the predicted tomato proteome (www.solgenomics.org) and identified eight genes encoding $\beta$ subunits. Phylogenetic analysis of the tomato and Arabidopsis $\beta$ subunits revealed that tomato genome has one gene for each of the six $\beta$ subunits ( $\beta 1, \beta 3, \beta 4, \beta 5, \beta 6$ and $\beta 7$ ), and two genes encoding $\beta 2$ (Fig.28A). The two $\beta 2$ proteins in tomato $(\beta 2 a$ and $\beta 2 b)$ are more closely related to each other when compared to the two $\beta 2$ proteins of Arabidopsis (PBB1 and PBB2), indicating that gene duplication occurred in each lineage, after the divergence. Alignment with the Arabidopsis orthologs indicates that each of the eight tomato genes encodes a putative functional subunit, including an $\mathrm{N}$-terminal prodomain for all subunits and a catalytic Thr for $\beta 1, \beta 2$ and $\beta 5$ (Fig.S2). 
A

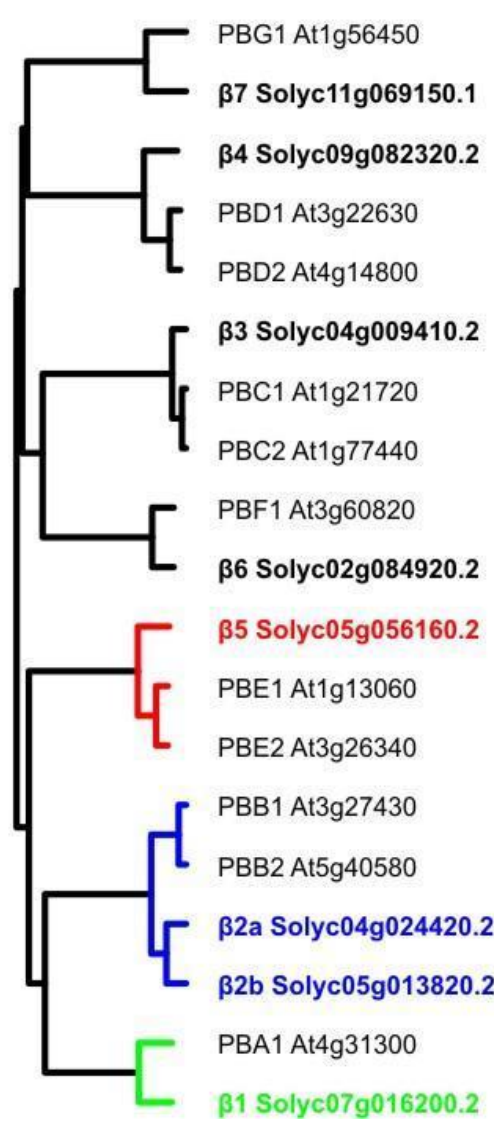

B

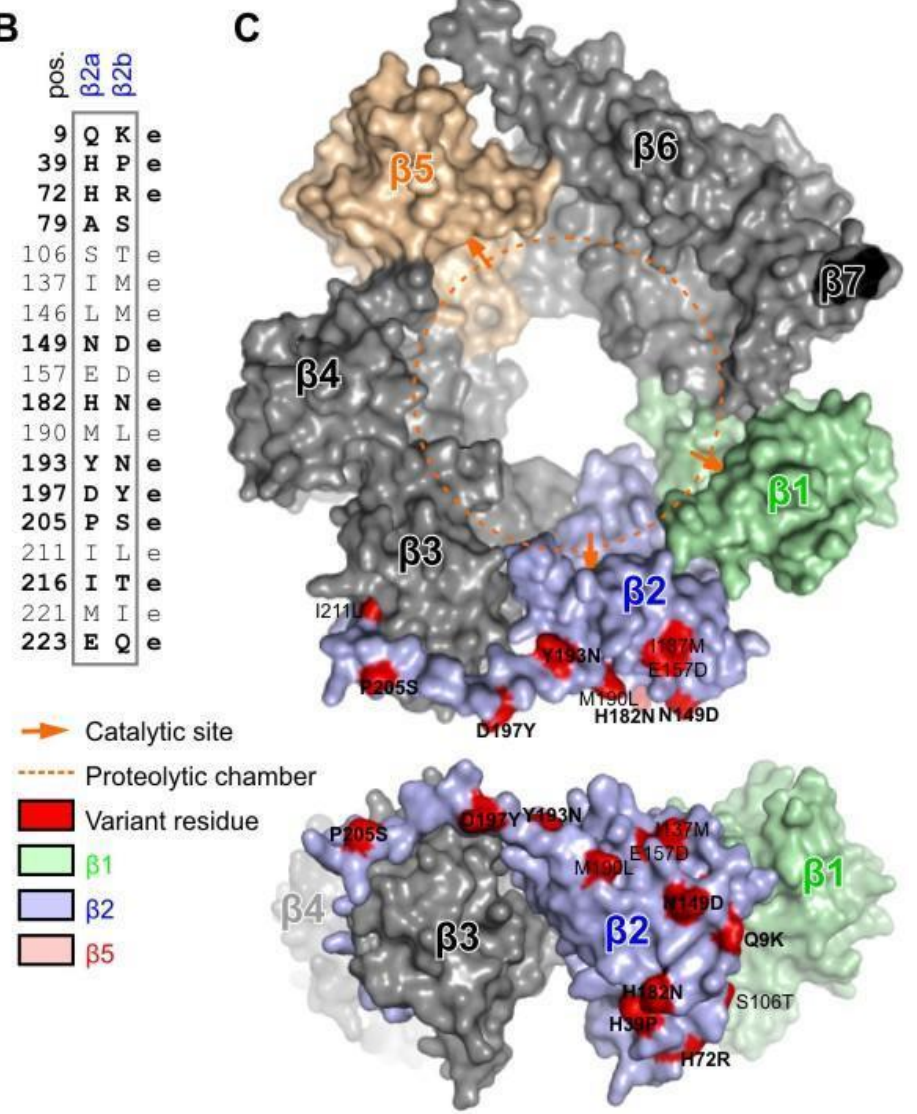

Figure 28 Phylogeny and variation of beta proteasome subunits of tomato. (A) Phylogenetic tree of beta subunit genes of tomato and Arabidopsis. Neighbour-joining tree of protein sequences was build using ClustalW2. (B) Summary of the variant amino acid residues that differ between $\beta 2 a$ and $\beta 2 b$. e, putative solvent-exposed. (C) Location of variant residues in $\beta 2$, modelled on the yeast proteasome. The tomato $\beta 2 a$ protein was modelled using the $\beta 2$ of yeast (2zcy) as a template. Residues that differ between $\beta 2 a$ and $\beta 2 \mathrm{~b}$ are highlighted in red in the topview (top) and sideview (bottom) of the $\beta$ ring of the proteasome and summarized in the table. The proteolytic chamber is highlighted with a dashed orange line and catalytic sites are indicated with orange arrows.

The branch lengths indicate that the two $\beta 2$ subunits are substantially different (Fig.28A). Indeed, we counted 18 amino acid residues that differ between the mature $\beta 2 a$ and $\beta 2 b$ subunits (Fig.28B). Most amino acid substitutions are biochemically dissimilar. To estimate if these variant residues can affect the proteolytic chamber, we generated a structural model of the tomato $\beta 2$ protein using the yeast proteasome (2zcy, Groll et al., 2008) as a template. Mapping the residues that vary between $\beta 2 a$ and $\beta 2 b$ onto the structural model revealed that none of the variant residues are exposed to the proteolytic chamber (Fig.28C). Interestingly, nearly all the variant residues reside on the outer surface and are likely solvent-exposed (Fig.28C). 


\subsection{Investigation of gene expression analysis of $\beta$ subunits upon other stress conditions}

To determine which of the $\beta$ subunit-encoding genes are expressed and if gene expression is stress responsive, we mined RNAseq datasets for the transcript levels of each of these genes. For this we exploited RNAseq data for different organs (Tomato Genome Consortium, 2012); treatment with the flg28 elicitor (Rosli et al., 2013); challenge with the fungal pathogen Cladosporium fulvum (llyas et al., 2015); and infection with the bacterial pathogen Pseudomonas syringae pv. tomato DC3000 (PtoDC3000, Rosli et al., 2013). As expected for subunits that assemble in stoichiometric complexes, transcript levels of each of the $\beta$ subunit genes are very similar, with the exception of $\beta 2 a$ transcripts, which accumulate 5-10-fold lower when compared to $\beta 2 \mathrm{~b}$ and the other $\beta$ subunit-encoding transcripts (Fig.29). The ratio between $\beta 2 a$ and $\beta 2 b$ transcript levels does not significantly change in different organs (Fig.29A), suggesting that proteasome assembly might be similar for $\beta 2 a$ and $\beta 2 b$ subunits in different organs.

Analysis of stress conditions demonstrates that all $\beta$ subunit-encoding genes are transcriptionally upregulated upon flg28 treatment, which activates PAMP-triggered immunity (PTI, Fig.29B). We also detect significant transcript upregulation upon challenge with avirulent Cladosporium fulvum, which activates effector-triggered immunity (ETI, Fig.29C). Infection with PtoDC3000, however, does not lead to differential transcript levels (Fig.29D). Taken together, this indicates that transcript levels are induced by PTI and ETI but not during compatible plant-pathogen interactions. The ratio between $\beta 2 a$ and $\beta 2 b$ transcript levels does not significantly change upon different stress treatments, suggesting that any stressinduced proteasome is unlikely to be caused by differential $\beta 2$ subunit assembly. 


\section{A}

\begin{tabular}{|l|r|r|r|r|r|r|r|r|}
\hline & $\boldsymbol{\beta} 1$ & $\boldsymbol{\beta} 2 \mathbf{a}$ & $\boldsymbol{\beta} \mathbf{2 b}$ & $\boldsymbol{\beta} 3$ & $\boldsymbol{\beta 4}$ & $\boldsymbol{\beta} 5$ & $\boldsymbol{\beta} 6$ & \multicolumn{1}{c|}{$\boldsymbol{\beta 7}$} \\
\hline Roots & 191 & 17 & 126 & 112 & 93 & 156 & 207 & 141 \\
\hline Leaves & 114 & 7 & 73 & 77 & 48 & 100 & 134 & 59 \\
\hline Flowers & 127 & 11 & 92 & 67 & 55 & 104 & 171 & 71 \\
\hline Green fruit & 89 & 17 & 80 & 87 & 48 & 100 & 134 & 102 \\
\hline Red fruit & 98 & 22 & 142 & 72 & 82 & 117 & 216 & 141 \\
\hline
\end{tabular}

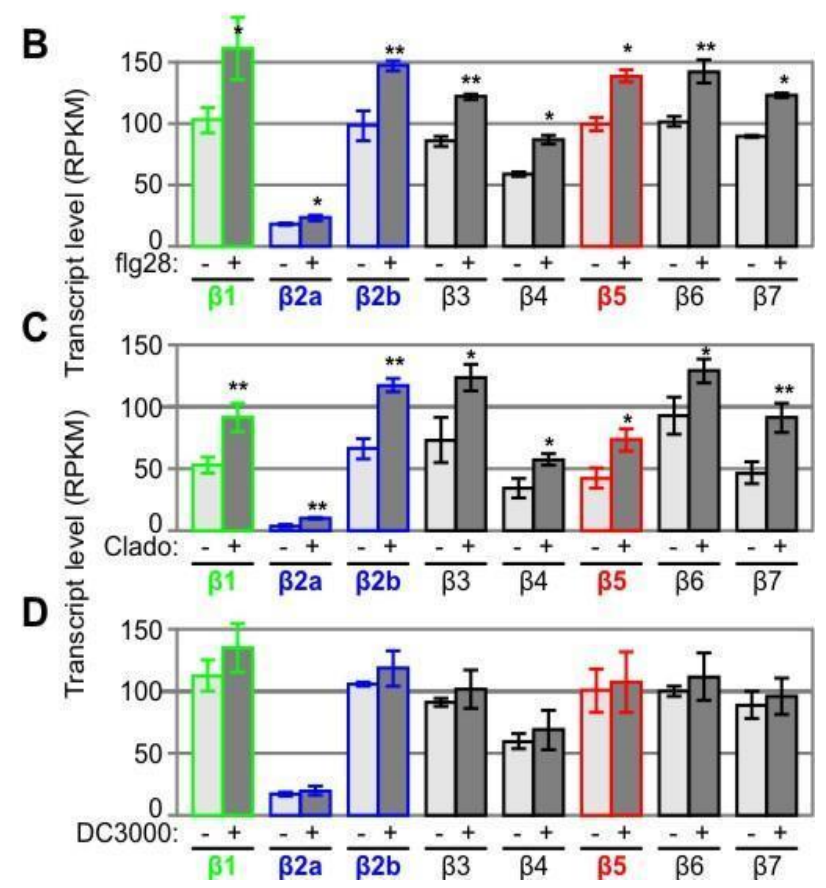

Figure 29 Transcript levels of beta subunit genes of tomato are induced by stress. (A) Transcript levels of $\beta$ subunit-encoding genes in various tomato organs. These data were extracted from The Tomato Genome Consortium (2012). Reads per kilobase of transcripts per million mapped reads (RPKM) values were extracted from the database and plotted for each gene. (B) Transcript levels of $\beta$ subunit-encoding genes in tomato leaves upon treatment with and without flg28. These data were extracted from Rosli et al., (2013). 4-week old tomato plants were infiltrated with and without $1 \mu \mathrm{M}$ flg28 and RNA was extracted from infected leaves six hours later. The transcriptome was sequenced and the RPKM values were extracted from the database and plotted for each gene. The error bars represent the standard error of three biological replicates. (C) Transcript levels of $\beta$ subunit-encoding genes in leaves of resistant tomato plants upon challenge with and without Cladosporium fulvum. Four-week-old plants were spray-inoculated with $1 \times 106$ conidia/ml or mockinoculated and RNA was extracted six days later. The transcriptome was sequenced and the RPKM values were extracted and plotted for each gene. The error bars represent the standard error of three biological replicates. (D) Transcript levels of $\beta$ subunit-encoding genes in tomato leaves upon inoculation with and without Pseudomonas syringae pv. tomato DC3000. These data were extracted from Rosli et al., (2013). 4-week old tomato plants were infiltrated with and without $5 \times 106$ bacteria/mL PtoDC3000 and RNA was extracted from infected leaves six hours later. The transcriptome was sequenced and the RPKM values were extracted from the database and plotted for each gene. The error bars represent the standard error of three biological replicates. (Means are significant at $\mathrm{P}<0.5\left(^{*}\right) ; 0.01\left(^{* *}\right)$ or $\left.0.001{ }^{* * *}\right)$ level as determined by Student's t-test). 


\subsection{Activity of proteasome catalytic subunits upon salt stress}

\subsection{Proteasome labeling with MV151 revealed altered proteasome activity profile}

To uncover whether activity of proteasome catalytic subunits alters upon salt stressinduced PCD we tested MV151, which labels both the proteasome and a subset of the PLCPs (Gu et al., 2010). MV151 labeling causes weak signals at 30-40 kDa which represent PLCPs and three stronger signals at $26 \mathrm{kDa}$ that may represent the active proteasome subunits or PLCPs (Fig.30A). Interestingly, we detected a strongly activated band at $\sim 26$ kDa with 3-fold higher intensity upon $250 \mathrm{mM}$ salt treatment at 6 hours (Fig.30B). This extra signal was robustly detected in biological replicates. To determine if this signal is caused by the proteasome or PLCPs, a competition assay was performed using proteasome inhibitor epoxomicin and PLCP inhibitor E-64. Pre-incubation with E-64 suppresses labeling at 30-40 kDa (Fig.30D), confirming that these signals are caused by PLCPs. The $26 \mathrm{kDa}$ signals are not suppressed by E-64 (Fig.30D), indicating that these signals might be from the proteasome. Indeed, pre-incubation with the selective proteasome inhibitor epoxomicin suppresses labeling of all $26 \mathrm{kDa}$ signals (Fig.30D), indicating that the significantly activated band is caused by the proteasome. Thus, although these MV151 labeling experiments did not display differential activities of PLCPs, it did uncover differential proteasome activity profiles. 

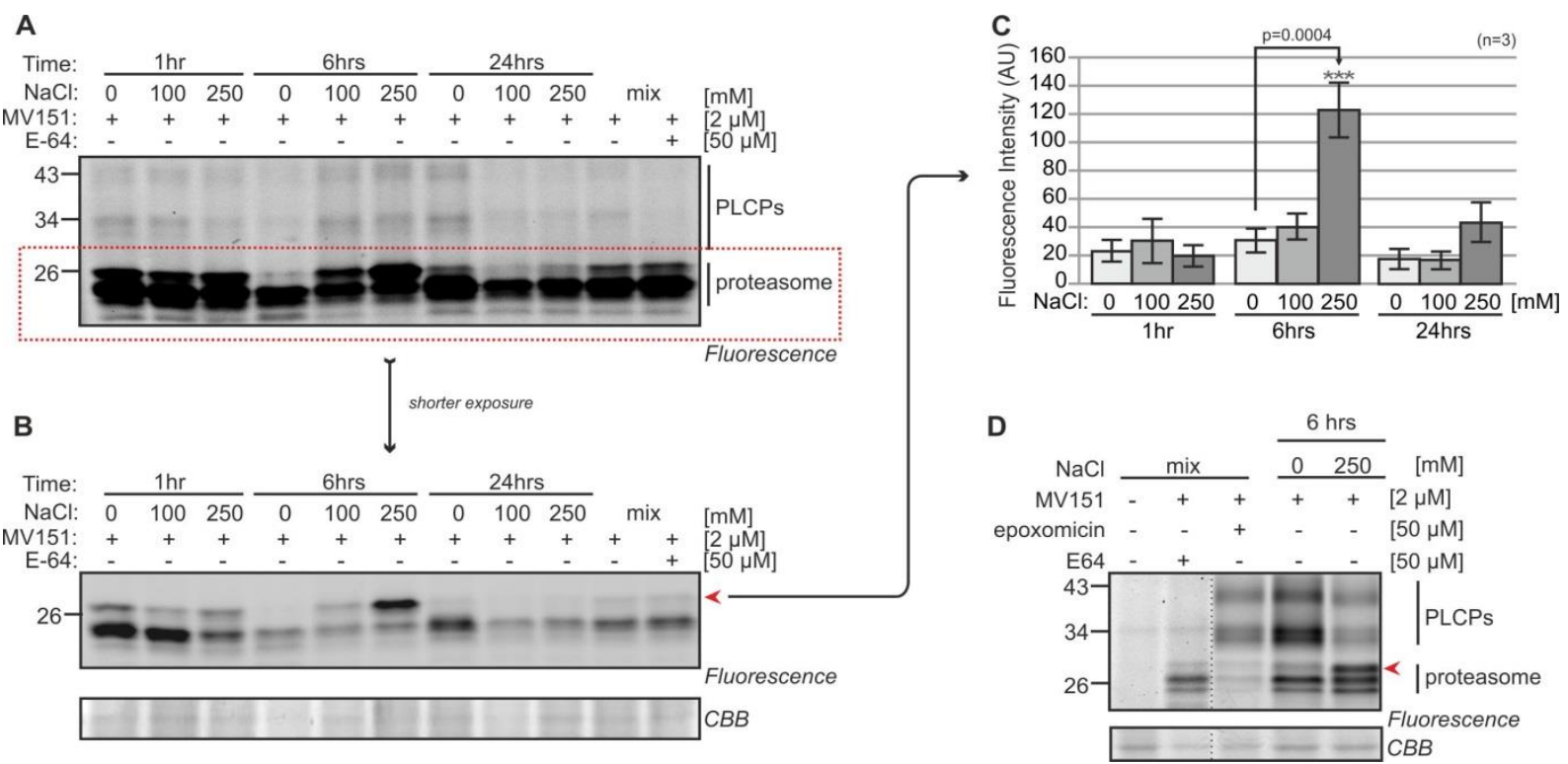

Figure $30 \quad$ MV151 labeling profile changes upon salt treatment. (A) Tomato roots were treated with 0,100, $250 \mathrm{mM} \mathrm{NaCl}$. Root extracts were generated after 1, 6 and 24 hours and labeled with $2 \mu \mathrm{M}$ MV151 at $\mathrm{pH}$ 6.0. A mix of all nine samples was preincubated with or without $50 \mu \mathrm{M}$ E-64 and labeled with $2 \mu \mathrm{M}$ MV151. (B) Shorter exposure of the section highlighted in (A). (C) Quantification of the upper differential MV151 signal over three biological replicates. Error bars represent SEM. (D) The 6 hours 0 - and $250 \mathrm{mM} \mathrm{NaCl}$ treated samples were labeled with $2 \mu \mathrm{M}$ MV151. A mix of the two samples were preincubated with or without E-64 or epoxomicin and labeled with or without $2 \mu \mathrm{M}$ MV151. (Means are significant at $\mathrm{P}<0.5\left(^{*}\right) ; 0.01\left(^{* *}\right)$ or $0.001\left(^{(* *}\right)$ level as determined by Student's t-test).

5.1.5.3.3.2Confirmation of altered proteasome catalytic subunits activity labeled by MVB072

To confirm differential proteasome activity, we used a newly re-synthesized epoxomicin-based MVB072, which carryies both a bodipy tag for fluorescent detection and a biotin tag for affinity purification (Kolodziejek et al., 2011). When compared to MV151, MVB072 is a much more selective proteasome probe without any known off targets, ideal to confirm differential proteasome activity in our samples (Kolodziejek et al., 2011). Importantly, MVB072 labeling displays the same altered activity profile upon salt treatment as MV151 labeling (Fig.31A). Quantification of fluorescence intensities of the various signals demonstrate a highly reproducible upregulation of the upper signal at $6 \mathrm{hrs}$ upon $250 \mathrm{mM}$ $\mathrm{NaCl}$ treatment, whilst other signals seem to reduce (Fig.31B).

Three different signals were detected, but the composition of these signals is still unknown. Therefore, subunit-selective inhibitors were used to identify the upper signal. N3 $\beta 1$ is an epoxyketone-based inhibitor that specifically inhibits the $\beta 1$ catalytic subunit of the proteasome, whereas N3 35 is a vinyl-sulfone-based inhibitor targeting the $\beta 5$ catalytic subunit of the proteasome (Verdoes et al., 2010; Misas-Villamil et al., 2017). Pre-incubation with N3 $\beta 1$ caused reduction in the fluorescence of the middle- and the lower signal in both of 
0 -, and $250 \mathrm{mM} \mathrm{NaCl}$ treated samples whereas preincubation with $\mathrm{N} 3 \beta 5$ reduced the signal intensity of the upper signal in the $250 \mathrm{mM} \mathrm{NaCl}$ treated sample (Fig.31C), suggesting that the upper differential signal is caused by a $\beta 5$ subunit.

A

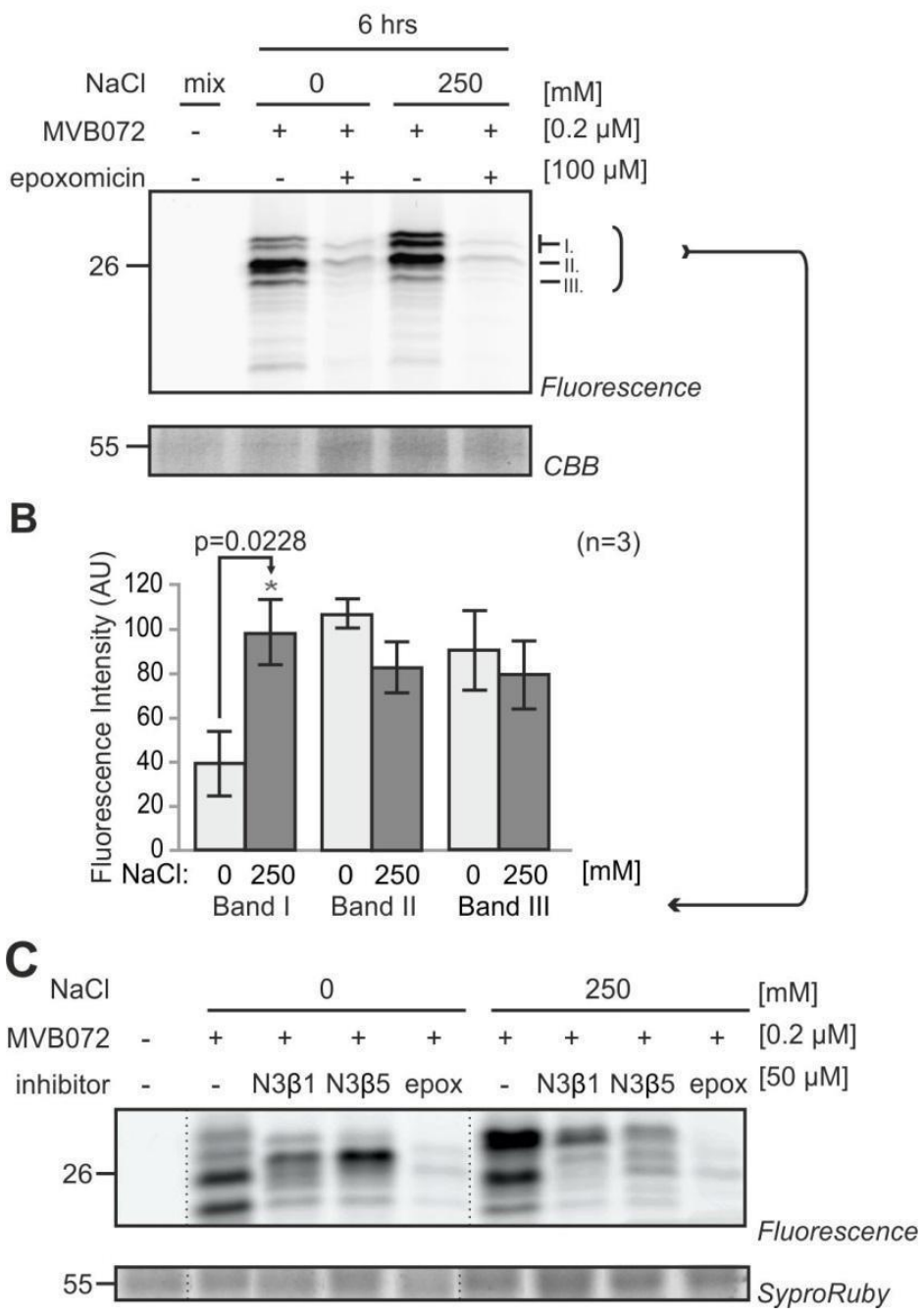

Figure 31 Proteasome activity changes upon salt treatment. (A) Tomato roots were treated with 0 and $250 \mathrm{mM} \mathrm{NaCl}$ and root extracts were generated after 6 hours and preincubated with or without $100 \mu \mathrm{M}$ epoxomicin and labeled with or without $0.2 \mu \mathrm{M}$ MVB072. (B) Three signals highlighted in (A) were quantified from three biological replicates. Error bars represent SEM of $n=3$ biological replicates. (C) Root extracts were preincubated with or without $50 \mu \mathrm{M} N 3 \beta 1, \mathrm{~N} 3 \beta 5$ or epoxomicin and labeled with $0.2 \mu \mathrm{M}$ MVB072. (Means are significant at $\mathrm{P}<0.5\left(^{*}\right) ; 0.01\left(^{* *}\right)$ or $0.001\left(^{* * *}\right)$ level as determined by Student's t-test).

\subsection{Identification of proteasome catalytic subunits}

5.1.5.3.4.1 Proteasome catalytic subunits separated by IEF 2D gel

To identify the differentially active catalytic subunits of the proteasome, we separated MVB072-labeled proteomes of roots treated with and without $250 \mathrm{mM} \mathrm{NaCl}$ for 6hrs by isoelectric focusing (IEF) and SDS gel electrophoresis. Over 14 fluorescent spots were 
robustly detected on 2D gels (Fig.32A). These fluorescent spots do not correlate with abundant proteins detected upon Sypro Ruby staining of these gels (Fig.S4). The fluorescence intensity of each of these 14 spots was quantified using ImageJ and plotted in a histogram over three biological replicates (Fig.32B and Fig.S5). We detect significant increase of the fluorescence intensities of spots \#5 and \#13 and a significant decrease of fluorescence intensities of spots \#8, \#10, \#11, \#13 and \#14, whilst fluorescence intensities of spots \#7 and \#9 were strongly increased upon salt treatment (Fig.32B). These changes in fluorescence intensities occurs in two regions in the 2D gel (boxed in Fig.32A) and correlates with the shift in fluorescent intensity on 1D gels, as illustrated in Fig.32C. At the acidic pl range, five spots (\#7-11) showed reduced intensity upon salt stress, whilst one spot (\#5) has increased signal intensity (blue box in Fig.32C). At basic pl range, the bottom signal (\#14) decreases whilst the top signal (\#13) intensifies upon salt stress (red box in Fig.32C).

A total of 28 fluorescent spots were excised from both gels and analyzed by MS. 27 of these spots contain catalytic subunits of the proteasome (Fig.S5-7, TableS1). In total, four different catalytic subunits were detected: Solyc07g016200.2.1 ( $\beta 1)$, Solyc04g024420.2.1 ( $\beta 2 a)$, Solyc05g013820.2.1 ( $\beta 2 b)$ and Solyc05g056160.2.1 ( $\beta 5)$, each with multiple unique peptides and significant Mascot protein scores (Fig.S6-S7 and TableS2).

$\beta 2$ a was identified in spots \#5, \#7 and \#10 in the control treatment and in spots \#4, \#5, and \#10 in the salt-treated sample (Fig.32D and Fig.S7). However, the majority of the MS signal in these spots comes from $\beta 2 b$ (Fig.S6). This indicates that $\beta 2 a$ is part of the proteasome, but contributes only a minor fraction, irrespective of the stress condition. These data do not support the hypothesis that the stress proteasome has a different $\beta 2 a / \beta 2 b$ ratio.

To assign the fluorescence signal to a particular catalytic subunit, we ranked the protein scores in Mascot for each spot and highlighted the four detected catalytic subunits. This analysis shows that we often identified more than one catalytic subunit from several spots (Fig.32D). The identification of multiple subunits per spot might be caused by incomplete separation during IEF or by contamination during gel excision. We assigned the signal to a single catalytic subunit in case a single subunit ranks consistently high in a spot. This way we assigned $\beta 1$ to spots \#1, \#2, \#3 and \#6; $\beta 2$ to \#4, and \#5; $\beta 5$ to \#13 and \#14, and we found stronger signals for multiple subunits in the remaining spots (\#8-12) (Fig.32E and Fig.S7). Taken together, these data indicate that salt stress induces a shift to a higher apparent MW for both labeled $\beta 2$ and $\beta 5$, and a shift to lower pl for labeled $\beta 5$. To assign the fluorescence signal to a particular catalytic subunit, we ranked the protein scores in Mascot for each spot and highlighted the four detected catalytic subunits. This analysis shows that we often identified more than one catalytic subunit from several spots (Fig.32D). The identification of multiple subunits per spot might be caused by incomplete separation during IEF or by contamination during gel excision. We assigned the signal to a single catalytic 
subunit in case a single subunit ranks consistently high in a spot. This way we assigned $\beta 1$ to spots \#1, \#2, \#3 and \#6; $\beta 2$ to \#4, and \#5; $\beta 5$ to \#13 and \#14, and we found stronger signals for multiple subunits in the remaining spots (\#8-12) (Fig.32E and Fig.S7). Taken together, these data indicate that salt stress induces a shift to a higher apparent MW for both labeled $\beta 2$ and $\beta 5$, and a shift to lower $p l$ for labeled $\beta 5$.

A

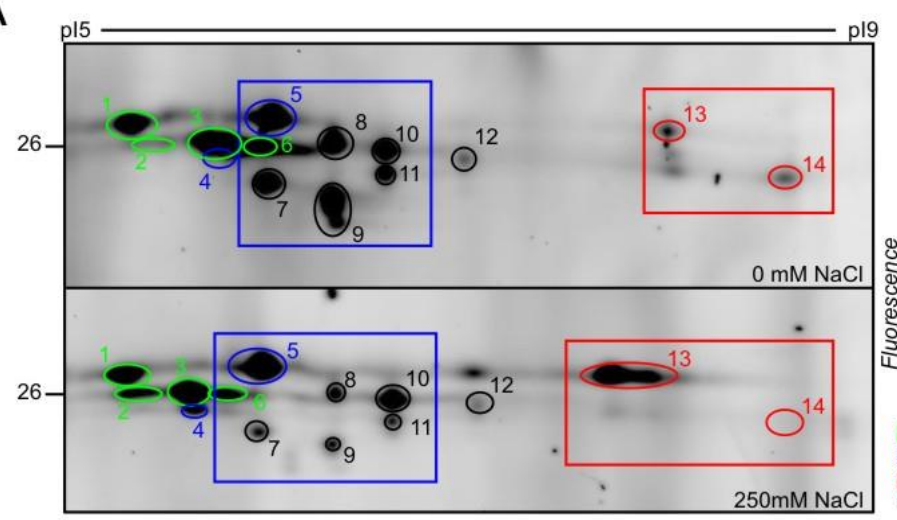

C
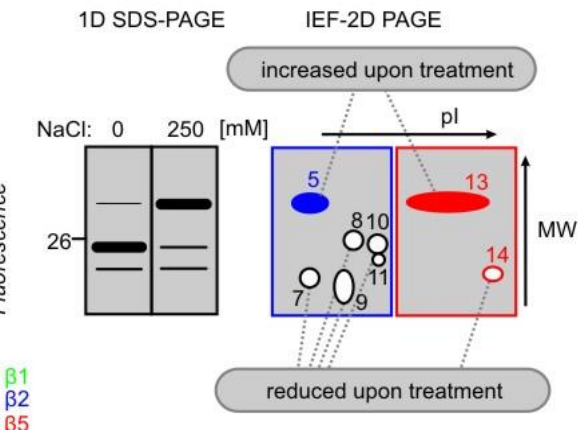

B
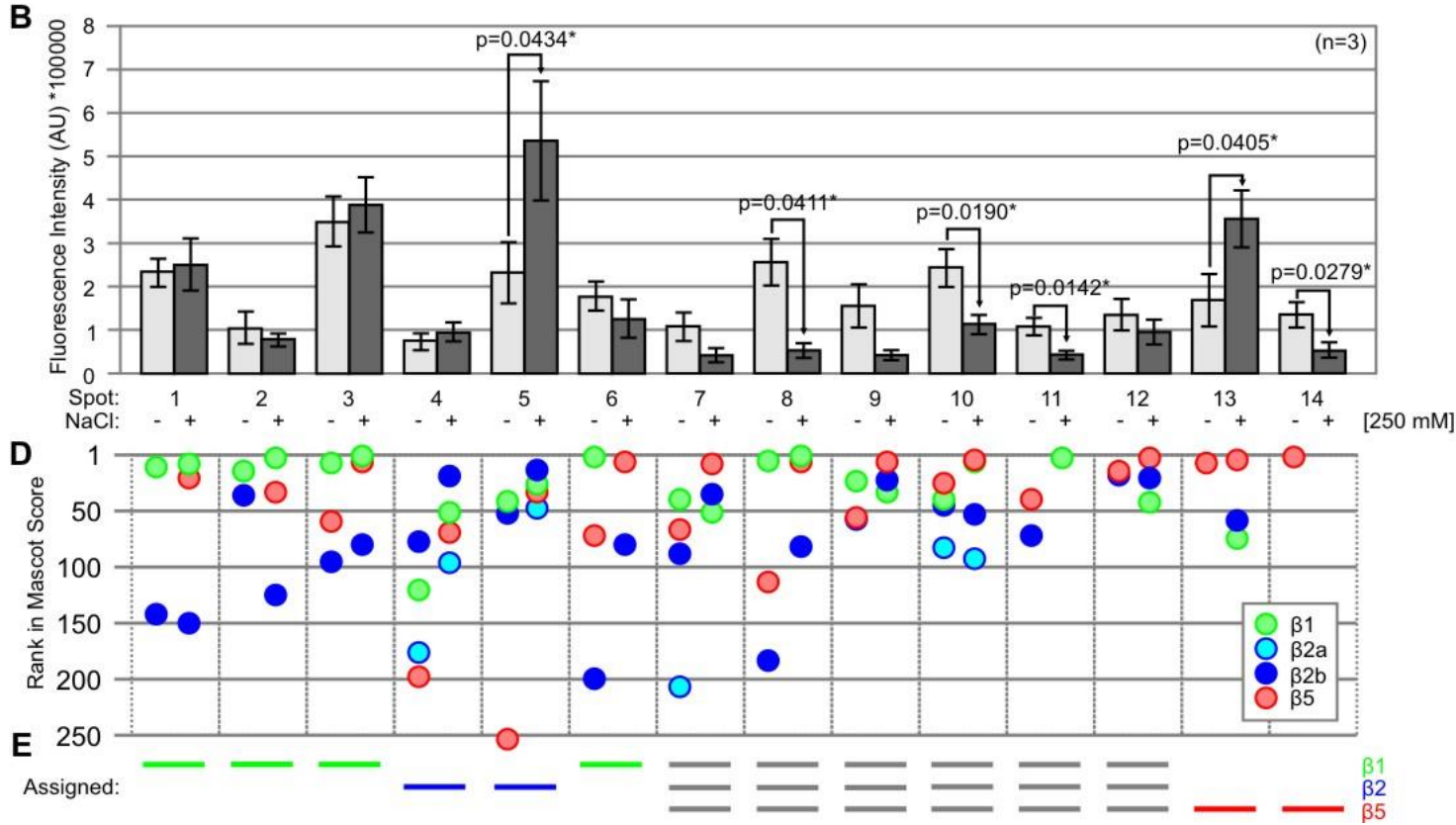

Figure 32 Two-dimensional gels show MW and pl shifts for catalytic subunits. (A) Tomato roots were treated with 0 and $250 \mathrm{mM} \mathrm{NaCl}$ and root extracts were generated after 6 hours and labeled with 0.2 $\mathrm{MM}$ MVB072. Samples were separated on IEF 2D gel. Spots are highlighted with different colors: $\beta 1$ (green); $\beta 2$ (blue); and $\beta 5$ (red). Framed sections focus on $\beta 2$ (blue) and $\beta 5$ (red) catalytic subunits. (B) Quantification of the fluorescence signals of (A). Error bars represent SEM of $n=3$ biological replicates. (C) Schematic figures of $1 \mathrm{D}$ and $2 \mathrm{D}$ gel illustrating the effect of high salinity on the intensity of signals of $\beta 2$ and $\beta 5$ catalytic subunits. Closed and open spots indicate up- and down-regulated signals, respectively. (D) Ranking of detected catalytic subunits based on Mascot protein scores. (E) Assignment of catalytic subunits to some of the fluorescent spots, based on the detected proteins and their scores and ranking. (Means are significant at $\mathrm{P}<0.5\left(^{*}\right) ; 0.01\left(^{(*}\right)$ or $0.001\left(^{* * *}\right)$ level as determined by Student's t-test). 


\subsection{Alteration of $ß 5$ subunits confirmed by subunit-specific ABPs}

To confirm the identity of the shifting of the catalytic subunits, the root extract was labelled with subunit-specific activity-based probes, LW124 and MVB127 (Li et al., 2013; Misas-Villamil et al., 2017). LW124 is specific for $\beta 1$ and has an epoxyketone reactive group and a fluorophore with excitation and emission wavelength at $470 \mathrm{~nm}$ and $530 \mathrm{~nm}$, respectively.
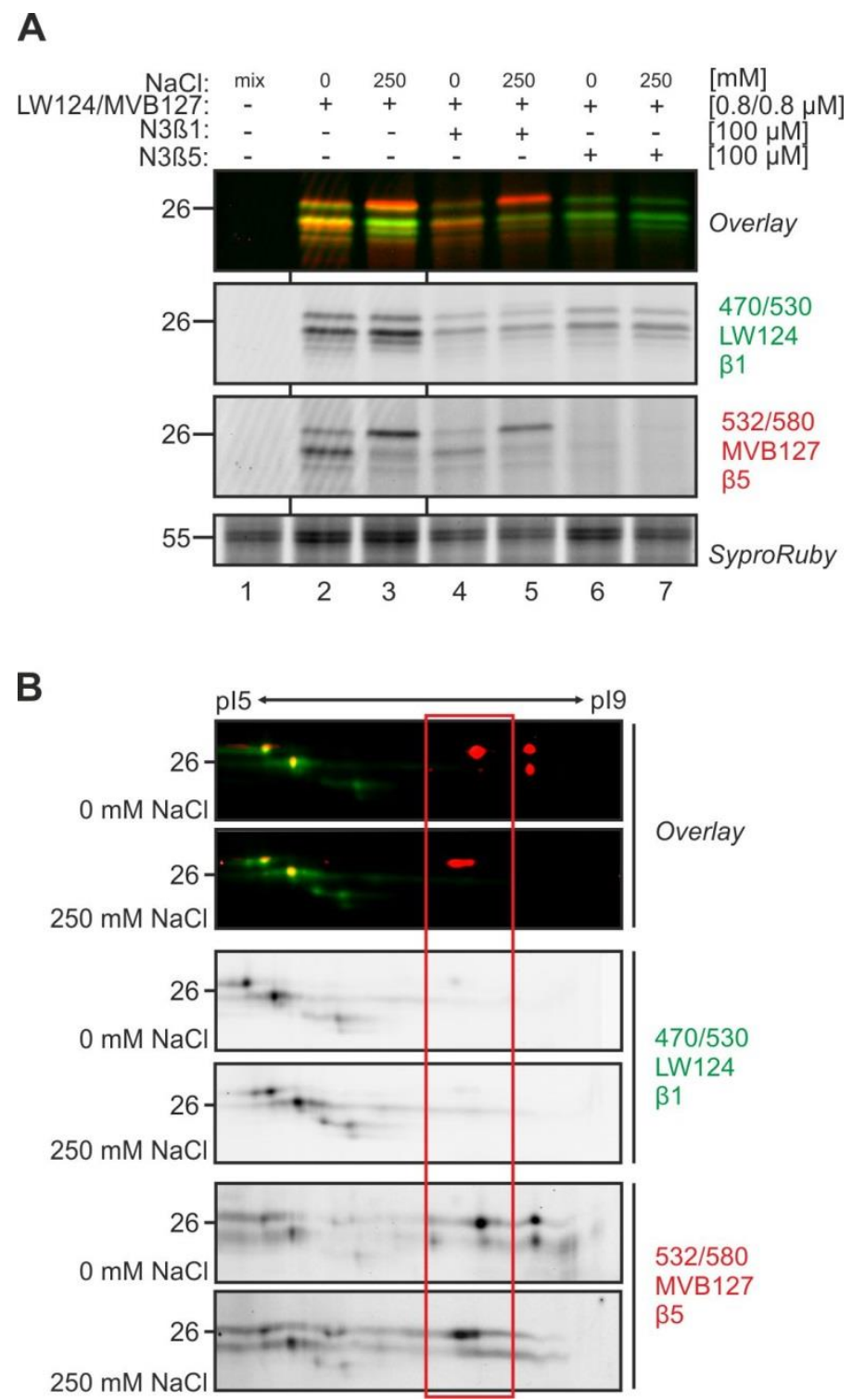

Figure 33 Subunit-specific labeling confirms modification of $\beta 5$ but not for $\beta 1$. (A) Tomato roots were treated with 0 - and $250 \mathrm{mM} \mathrm{NaCl}$ and root extracts were generated after 6 hours and preincubated with or without subunit-specific inhibitors, N3 31 and N3 35 and co- labeled with or without subunit-selective probes, LW124 ( $\beta 1)$ and MVB127 (B5). Samples were separated on 1D gel. (B) Tomato roots were treated with 0 - and $250 \mathrm{mM} \mathrm{NaCl}$ and root extracts were generated after 6 hours and co-labeled with LW124 ( $\beta 1)$ and MVB127 ( $\beta 5)$ and separated on IEF 2D gel. 
By contrast, MVB127 is selective for $\beta 5$, carries a vinyl-sulfone reactive group and a fluorophore with excitation and emission wavelength at $532 \mathrm{~nm}$ and $580 \mathrm{~nm}$, respectively.

As they have different specifies and their excitation and emission wavelength are different, LW124 and MVB127 can be used by co-labelling (Misas-Villamil et al., 2017). LW124 labeling does not display significant differences upon salt treatment (Fig.33A), consistent with earlier observations that $\beta 1$ labeling is unaffected. MVB127 labeling, however, shows a shift upwards, confirming the MW shift of $\beta 5$. To confirm the composition of the LW124- or MVB127-labeled signals, we preincubated the samples with selective inhibitors, N3 $\beta 1$ and N3 $\beta 5$. N3 35 suppressed labeling of MVB127 whereas N3 $\beta 1$ partially suppressed labeling of LW124, respectively, verifying that the top differential MV151- and MVB072 signals are caused mainly by a $\beta 5$ subunit (Fig.33A).

To confirm the pl shlft of the $\beta 5$ subunit we analyzed LW124/MVB127 co-labeled samples on 2D gels (Fig.33B). The MVB127-labeled signals increase at lower pl whereas signals at higher pl disappear upon salt treatment. This finding is consistent with the negative pl shift of $\beta 5$. By contrast, LW124-labeled signals are constant in the samples treated with or without salt (Fig.33), consistent with earlier observations that $\beta 1$ remains unaltered upon salt stress. Taken together this data demonstrate a pl/MW shift for $\beta 5$ upon salt treatment.

\subsection{Investigation of potential reason of $ß 2 \mathrm{MW}$ - and $ß 5 \mathrm{pl} / \mathrm{MW}$ shifts}

5.1.5.3.4.3.1 Investigation of two PTMs - phosphorylation and glycosylation

We next tested if the MW shifts are caused by phosphorylation. Treatment of MVB072-labeled sample with alkaline phosphatase did not affect the shifted signal, but removed the signal of phosphorylated MAP kinases detected by a phosphospecific antibody (Fig.34AB). We next studied whether the active subunits are differentially glycosylated by incubating the MVB072-labeled sample with PNGase $\mathrm{F}$ to remove N-glycans or with deglycosylation mix to remove both $\mathrm{N}$ - and O-glycans. None of these treatments affected the labeling profile (Fig.34C). By contrast, Bovine Fetuin, a standard glycoprotein did shift upon both treatments (Fig.34D). We conclude that the pl/MW shifts are not caused by phosphorylation or glycosylation of the catalytic subunits. 

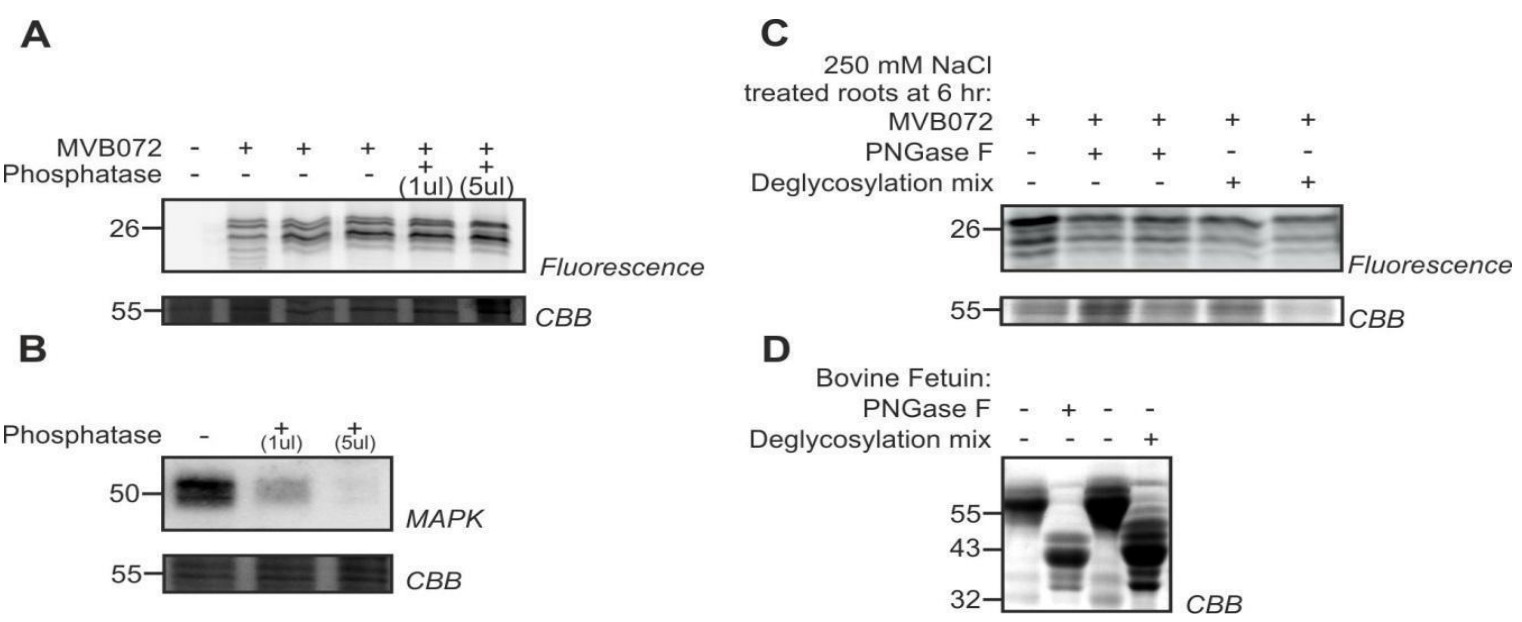

Figure 34 Phosphatase and deglycosylation treatments do not affect altered proteasome activity profile. (A) $250 \mathrm{mM}$ treated-samples labeled by MVB072 were treated with alkaline phosphatase at different conditions. (B) MAPK was used as a positive control detected by a phosphospecific antibody. (C) $250 \mathrm{mM}$ treated-samples labeled by MVB072 were treated with and without PNGase F or Deglycosylation mix. (D) Enzymatic deglycosylation of Bovine Fetuin was used as a positive control.

\subsection{Investigation of the role of $A B A$ in salt stress responses of tomato}

$A B A$ is an essential phytohormon, referred as a stress hormon to survive abiotic stress and a central regulator that plays important role on the acclimation proccess to salinity. We applied ABA-deficient mutant, sitiens (sit) that is defective in the gene coding for ABAaldehyde oxidase necessary for conversion of ABA-aldehyde to ABA (Audenaert et al., 2002). We investigated several physiological responses of sitiens tomato mutants compared to the wild type (wt) after $100 \mathrm{mM}$ - and $250 \mathrm{mM} \mathrm{NaCl}$ treatments. One of the most important question is whether ABA-deficient plants show altered proteolysis under salt stress.

\subsubsection{Detection of cell viability}

\subsubsection{FDA staining}

We studied the effect of sublethal- $(100 \mathrm{mM} \mathrm{NaCl})$ and lethal $(250 \mathrm{mM} \mathrm{NaCl})$ salt stress on ABA mutant (sitiens) tomato roots after 6 hours. Root tips were stained with FDA to detect and quantify the viable cells. Sublethal salt treatment was already sufficient to significantly decrease cell viability in sitiens ( sit $^{-}$) and lethal salt stress further reduced FDA staining compared to the wild type (wt) where $100 \mathrm{mM} \mathrm{NaCl}$ did not have any effect on cell viability and $250 \mathrm{mM} \mathrm{NaCl}$ only slightly decreased FDA staining (Fig.35). 


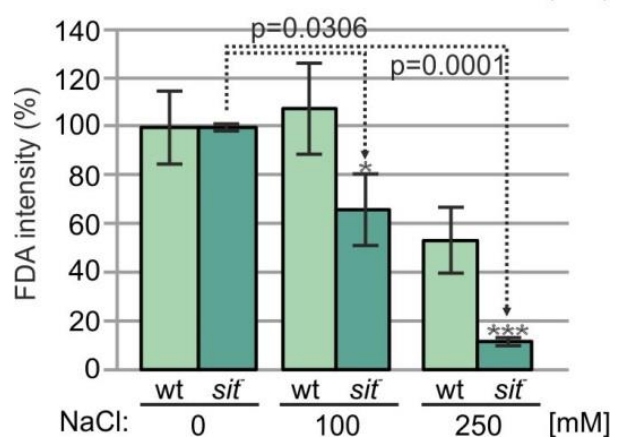

Figure 35 Fluorescence intensities of FDA in the roots of wild type and in sitiens mutant of tomato upon $0,100,250 \mathrm{mM} \mathrm{NaCl}$ treatment after $6 \mathrm{~h}$. (Means are significant at $\mathrm{P}<0.5\left(^{*}\right)$; $\left.0.01{ }^{* *}\right)$ or $\left.0.001{ }^{* * *}\right)$ level as determined by Student's t-test).

\subsubsection{Electrolyte leakage}

Detection of electrolyte leakage $(E L)$ revealed massive increment upon lethal salt treatment both in sitiens and wt, however, alteration of membrane integrity was more significant in sitiens compare to the wt. EL was similar to the control condition upon $100 \mathrm{mM}$ $\mathrm{NaCl}$ treatment (Fig.36).

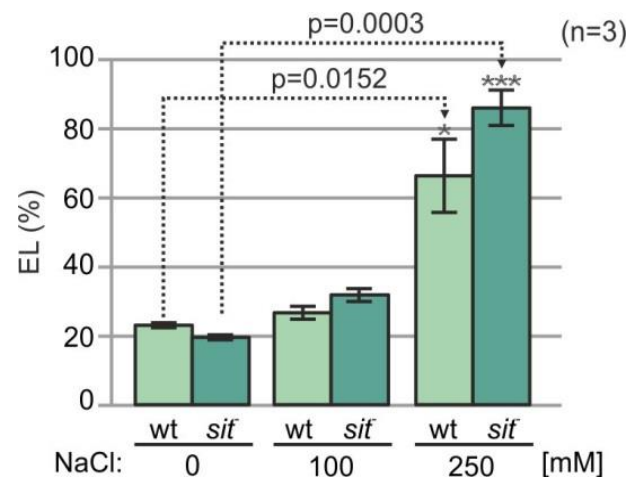

Figure $36 \quad$ Alteration of membrane integrity in the roots of wild type and in sitiens mutant of tomato upon 0,100 and $250 \mathrm{mM} \mathrm{NaCl}$ treatment after 6 hours. (Means are significant at $\left.\mathrm{P}<0.5\left(^{*}\right) ; 0.01{ }^{* *}\right)$ or $0.001\left(^{* * *}\right)$ level as determined by Student's t-test).

\subsubsection{Detection of oxidative burst}

\subsubsection{Total ROS content}

To analyse ROS burst, ROS production was detected upon sublethal-, and lethal salt treatments after 6 hours. Under control condition and at $100 \mathrm{mM} \mathrm{NaCl}$ significantly higher ROS production was detected in sitiens mutants after sublethal salt treatment. Interestingly, ROS production significantly decreased upon $250 \mathrm{mM} \mathrm{NaCl}$ treatment after 6 hours (Fig.37). 


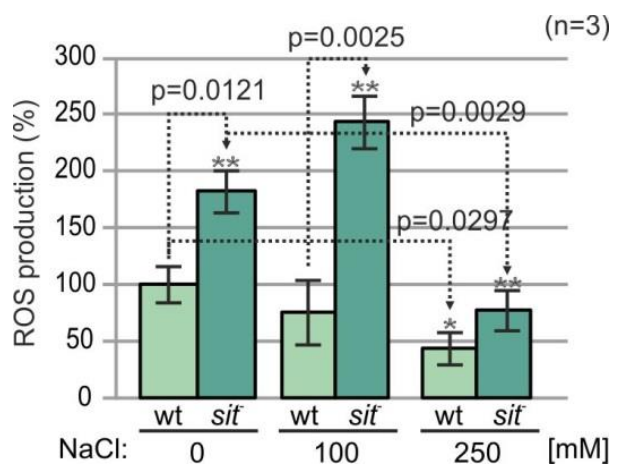

Figure 37 ROS generation in the roots of wild type and sitiens mutants of tomato upon 0 , 100 and $250 \mathrm{mM} \mathrm{NaCl}$ treatment after 6 hours. (Means are significant at $\mathrm{P}<0.5\left(^{*}\right) ; 0.01\left(^{* *}\right)$ or $\left.0.001{ }^{* * *}\right)$ level as determined by Student's t-test).

\subsubsection{2 $\mathrm{H}_{2} \mathrm{O}_{2}$ content}

$\mathrm{H}_{2} \mathrm{O}_{2}$ content showed opposite alteration in the roots of wild type and sitiens mutants. While in wild type $\mathrm{H}_{2} \mathrm{O}_{2}$ content increased upon both treatments, in sitiens it was decreased similar to changes in NO production upon sublethal salt treatments, however alteration of $\mathrm{H}_{2} \mathrm{O}_{2}$ is not significant. By contrast, increasing tendency was detected in wild type upon 250 $\mathrm{mM} \mathrm{NaCl}$ treatment (Fig.38).

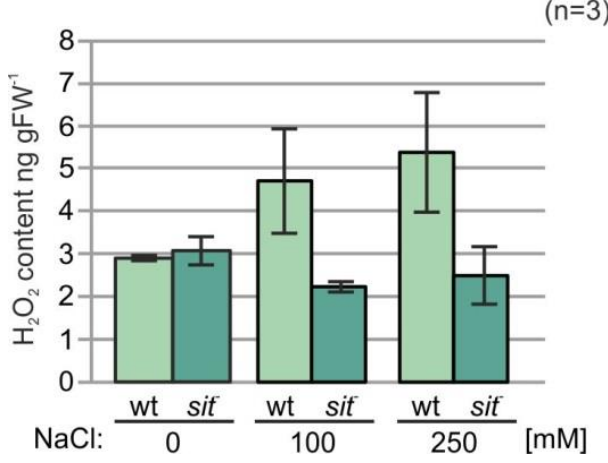

Figure $38 \quad \mathrm{H}_{2} \mathrm{O}_{2}$ production in the roots of wild type and sitiens mutants of tomato upon 0 , 100 and $250 \mathrm{mM} \mathrm{NaCl}$ treatment after 6 hours. Mean $+\mathrm{SE}, \mathrm{n}=3$. (Means are significant at $\mathrm{P}<$ $\left.0.5\left(^{*}\right) ; 0.01{ }^{* *}\right)$ or $\left.0.001{ }^{* * *}\right)$ level as determined by Student's t-test).

\subsubsection{NO content}

NO production exhibits also an opposite change to total ROS, while NO production slightly increases in the wild type, it decreases in sitiens upon sublethal salt treatment compared to the control condition. However, NO production relapses into control level in the wild type, it remains unchanged compared to $100 \mathrm{mM} \mathrm{NaCl}$ in sitiens upon $250 \mathrm{mM} \mathrm{NaCl}$ treatment (Fig.39). 


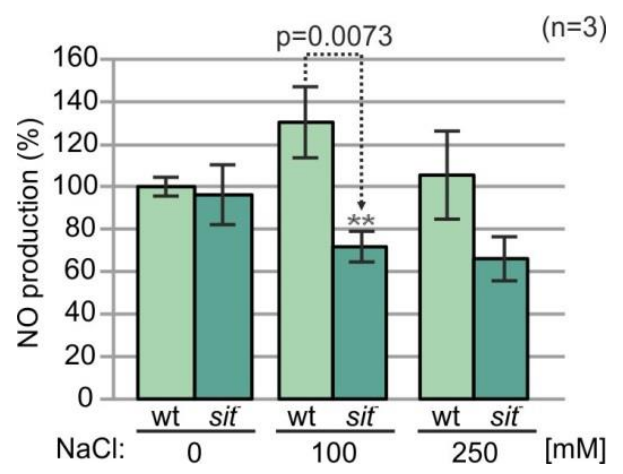

Figure 39 Kinetics of nitric oxide (NO) production in the roots of wild type and sitiens mutants of tomato upon 0,100 and $250 \mathrm{mM} \mathrm{NaCl}$ treatment after 6 hours. Mean $+\mathrm{SE}, \mathrm{n}=3$. (Means are significant at $\mathrm{P}<0.5\left({ }^{*}\right) ; 0.01\left(^{* *}\right)$ or $0.001\left(^{* * *}\right)$ level as determined by Student's t-test).

\subsubsection{DNA fragmentation}

We investigated PCD by DNA fragmentation which was more advanced in sitiens mutants compared to the wild type upon lethal salt stress after 6 hours (Fig.40).

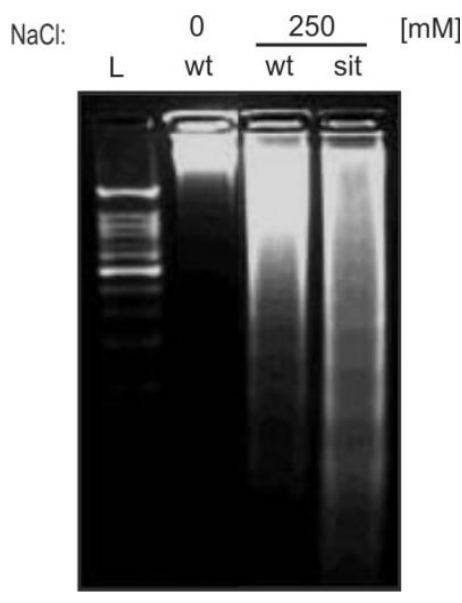

Figure 40 DNA fragmentation in the roots of wild type and sitiens mutant of tomato upon $250 \mathrm{mM} \mathrm{NaCl}$ treatment after 6 hours.

\subsubsection{Investigation of protein degradation}

\subsubsection{Total protein content}

To investigate protein degradation under different salt treatments we measured protein content with Bradford method. Interestingly, sitiens is already sensitive to $100 \mathrm{mM} \mathrm{NaCl}$ treatment and its protein content significantly decreases compared to the wild type under low salt stress. Interestingly, protein content slightly decreases upon $250 \mathrm{mM}$ salt treatment compared to the untreated control and sublethal salt stress after 6 hours and there is no difference in total protein level between wild type and sitiens mutants (Fig.41). 


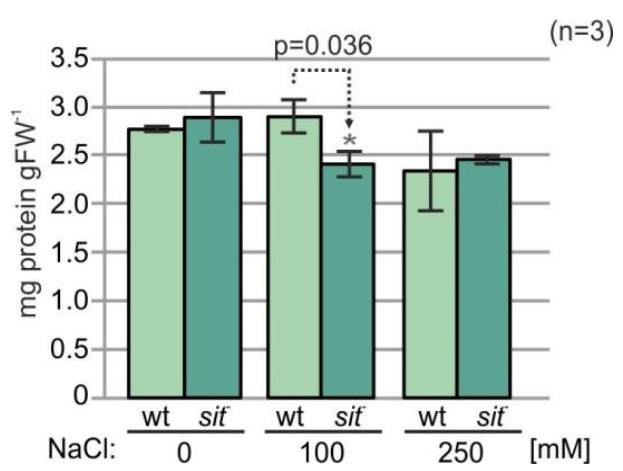

Figure 41 Total protein content in the roots of wild type and sitiens mutants of tomato upon 0, 100 and $250 \mathrm{mM} \mathrm{NaCl}$ treatment after 1, 6 and 24 hours. (Means are significant at $\left.\mathrm{P}<0.5\left(^{*}\right) ; 0.01{ }^{(* *}\right)$ or $0.001\left(^{* * *}\right)$ level as determined by Student's t-test).

\subsubsection{Proteolytic activity}

\subsubsection{Azocaseinolytic activity}

To study the reason of protein decrease we measured proteolytic activity by azocaseinolytic assay. Proteolytic activity clearly increases in sitiens mutants while protein content decreases upon $100 \mathrm{mM} \mathrm{NaCl}$ treatment. However, it does not increase further upon lethal salt stress parallel with alteration of protein content. In addition, proteolysis in the wild type increases only after $250 \mathrm{mM} \mathrm{NaCl}$ treatment which is consistent with the earlier observation protein measurement altered after lethal salt treatment (Fig.42). The tendency in the proteolytic activity correlates well with the changes in total protein contents.

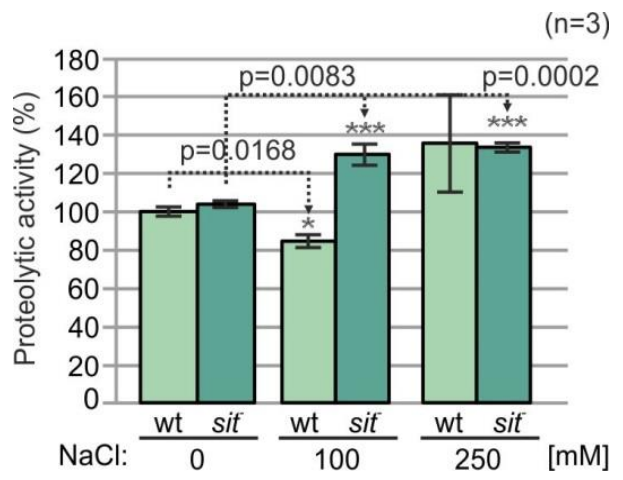

Figure 42 Azocaseinolytic activity in the roots of wild type and sitiens mutants of tomato upon 0, 100 and $250 \mathrm{mM} \mathrm{NaCl}$ treatment after 1, 6 and 24 hours. (Means are significant at $\mathrm{P}<0.5\left(^{*}\right) ; 0.01\left(^{* *}\right)$ or $\left.0.001{ }^{* * *}\right)$ level as determined by Student's t-test).

\subsubsection{Zymography}

Different methods were applied to investigate proteolytic activity in sitiens mutant, as well. We used zymography, gelatin-SDS PAGE that provides a common view of proteolytic activity. However, if we focus only to the signals derived from treated samples protease 
activity is higher in sitiens mutant upon sublethal salt stress in contrast to lethal salt stress where protease activity is significantly higher in the wild type than in the mutant (Fig.43).
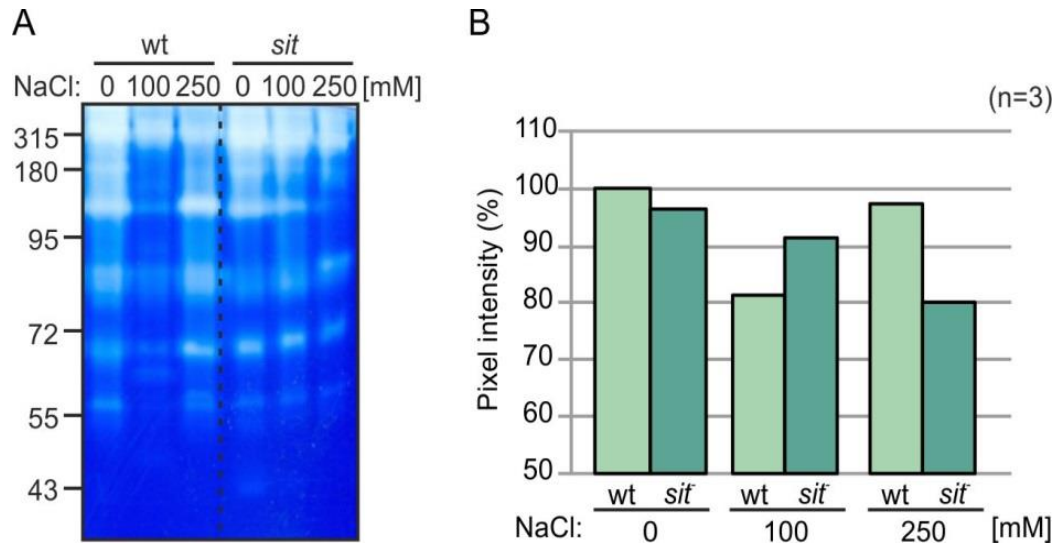

Figure 43 Protease activity in the roots of wild type and sitiens mutants of tomato upon 0 , 100 and $250 \mathrm{mM} \mathrm{NaCl}$ treatment after 1, 6 and 24 hours.

\subsubsection{Alteration of papain-like cysteine proteases (PLCPs) in sitiens mutants}

It is difficult to specifically detect Cys proteases by using zymogram. Thus, we applied the more sensitive ABPP to label PLCPs with PLCP-specific fluorescent probe, MV201.

A

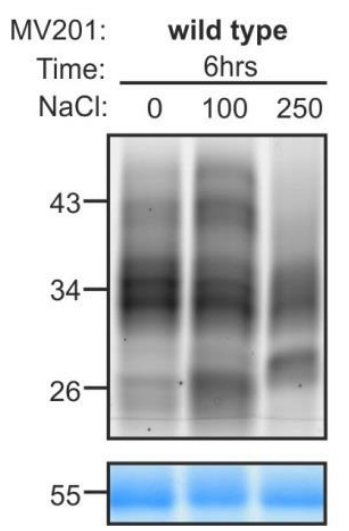

B

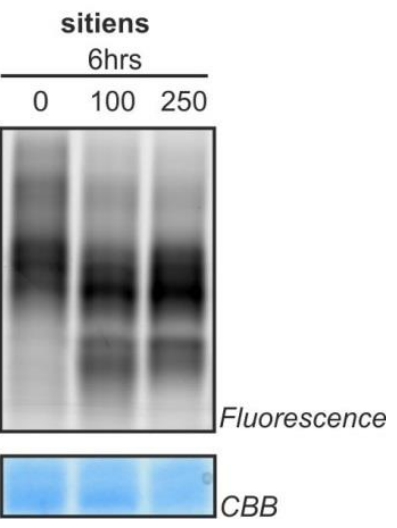

Figure 44 Salt stress in tomato wild type and sitiens roots differentially alters activity of PLCPs. Activation of PLCPs upon 0, 100 and $250 \mathrm{mM} \mathrm{NaCl}$ treatment after 6 hours in wild type $(A)$ and in sitiens roots $(B)$.

This shows that sitiens mutants have higher basal PLCP activity at 34 and $43 \mathrm{kDa}$ upon control condition. In contrast to the wild type, intensities of 34 and $28 \mathrm{kDa}$ bands increase after exposure to sublethal and lethal salt stress in sitiens mutants, while the bands at $43 \mathrm{kDa}$ exhibits decreased activity in the mutants under salt stress (Fig. 44). 


\subsection{Expression level of papain-like cysteine proteases (PLCPS)}

We examined the expression of previously identified PLCPS. RD19A and SAG12 showed the same expression level in wild type and sitiens, RD21A and AALP are downregulated and $X B C P 3$ is upregulated in sitiens under control condition. Expression of $A A L P$ does not change in ABA deficient mutant either upon sublethal or lethal salt stress compared to the control condition, furthermore, it is downregulated in wild type. SAG12 is overexpressed both in wild type and in sitiens mutants upon $100 \mathrm{mM} \mathrm{NaCl}$ and its expression is further increased in wild type upon $250 \mathrm{mM} \mathrm{NaCl}$. RD19A is only overexpressed in sitiens mutants upon $100 \mathrm{mM} \mathrm{NaCl}$ treatment but its expression is not effected upon lethal salt stress (Fig. 45).
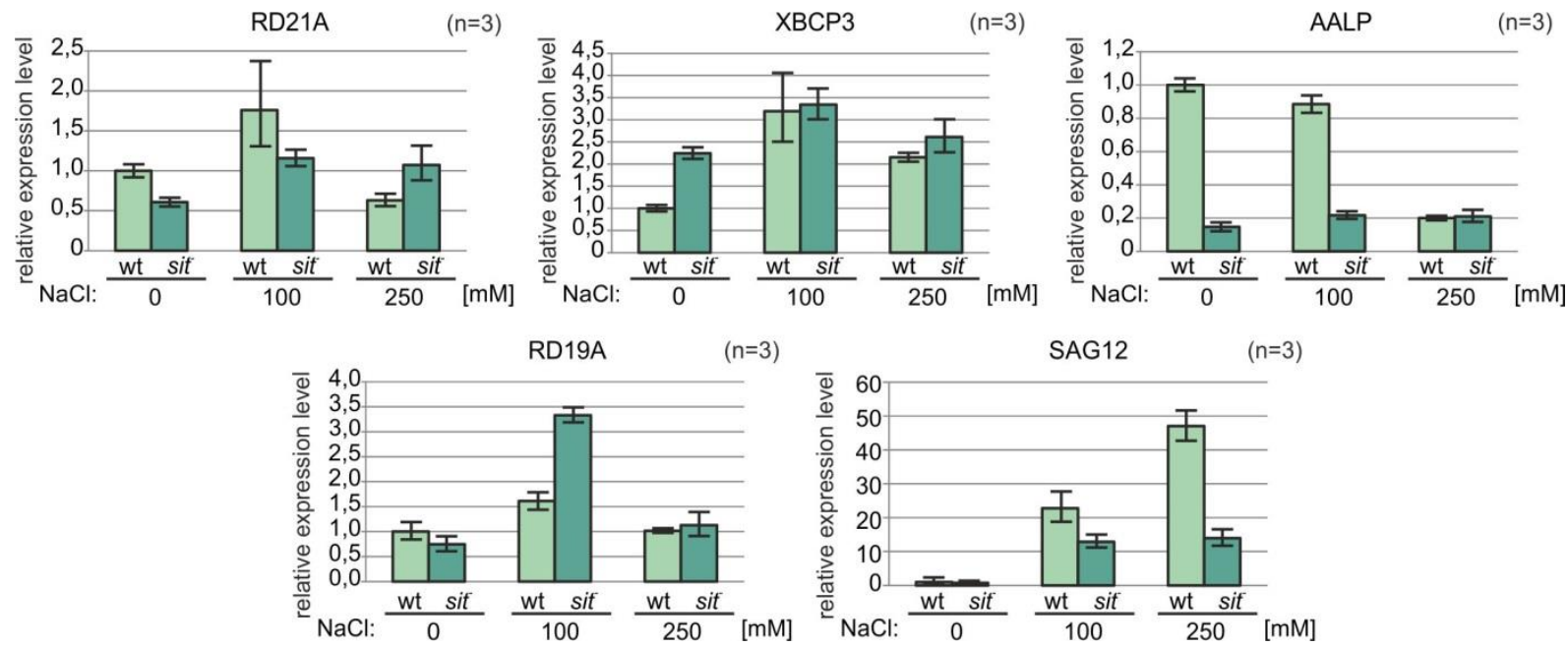

Figure 45 Gene expression of Cys proteases in root upon 0-, 100- and $250 \mathrm{mM} \mathrm{NaCl}$ treatment after 6 hours.

The increase in Cys protease activity in ABA biosynthesis mutant occurs in parallel with the expression RD19A in sitiens roots, while the expression of other Cys proteases were similar (RD21A, XBCP3) or more reduced (AALP and SAG12) to those of wild type under salt stress. 


\section{Discussion}

Here we have compared the effects of sublethal- $(100 \mathrm{mM} \mathrm{NaCl})$ and lethal $(250 \mathrm{mM}$ $\mathrm{NaCl}$ ) salt stress on ionic stress, ROS and NO production and on the induction of proteolysis with special emphasis on Cys proteases and proteasome in tomato plants. We detected a robust and quick PCD upon high salinity caused by $250 \mathrm{mM} \mathrm{NaCl}$ where robust alteration of membrane integrity, quick ROS- and NO burst and increased proteolysis were revealed in tomato. The changes were specific for different plant organs, therefore, leaf- and root tissues of tomato were studied separately.

\subsection{PCD events}

Salt stress has rapid and stronger effect on the viability of the root tips compared to the leaf tissue (Leshem et al., 2007). DNA laddering has been observed already at one hour upon salt exposure in the roots (Affenzeller et al., 2008). We observed suppression of the viability of the roots also after one hour, which develops further after six hours upon high salt treatment and delayed, slight decrease of viable cells was detected upon sublethal salt treatment after 24 hours (Fig.12AB). Imbalance of ionic homeostasis, especially cytosolic $\mathrm{K}^{+}$, is a critical point of salinity-induced PCD in plant cells (Zepeda-Jazo et al., 2008; Demidchik et al., 2010; Kim et al., 2014). Moreover, $\mathrm{K}^{+}$efflux was reliable indicator of salinity tolerance and showed significant alterations between the functionally different root zones in barley already after one hour $80 \mathrm{mM}$ salt exposure (Chen et al., 2005). In the case of tomato, roots appears to be more susceptible to salinity regarding both $\mathrm{K}^{+}$efflux and $\mathrm{Na}^{+}$influx even if it was treated by sublethal salt treatment after 24 hours. $250 \mathrm{mM}$ salt treatment dramatically alters the $\mathrm{Na}^{+}$content of leaf tissue probably by transportation of excess $\mathrm{Na}^{+}$ions to the shoot. Imbalance of ionic homeostasis nicely correlates with the reduction of $\mathrm{K}^{+} / \mathrm{Na}^{+}$over the increments of salt concentration (Table 1).

Electrolyte leakage, a typical method to monitor ion imbalance, showed extreme increments already after one hour that turned into irreversible at six hours in tomato root tips exposed to $250 \mathrm{mM} \mathrm{NaCl}$. Overall, leaves showed slightly delayed and milder response in the aspect of membrane integrity (Fig. 13), ROS and NO accumulation (Fig.14 and Fig.16), total proteolytic activity (Fig.18) and consequently decreased protein content (Fig.17). Only $\mathrm{H}_{2} \mathrm{O}_{2}$ level was significantly higher and increased in leaves compared to the decreased $\mathrm{H}_{2} \mathrm{O}_{2}$ content of roots supporting the hypothesis that $\mathrm{H}_{2} \mathrm{O}_{2}$ can have a systemic signalling role in response to high salinity and contributes to the acclimation of leaf tissues (Baxter et al., 2013; Fig. 15). Moreover, the simultaneous alteration of ROS and NO content as a function of time can also be a crucial point in the context of organ-specified survive or salinity-induced 
PCD (Brigth et al., 2006). We revealed a decreased NO production at 24 hours in roots which might be due to a decreased nitrate reductase activity or $\mathrm{NO}$ can react with $\mathrm{O}_{2} \cdot$ forming peroxinitrite another possible explanation of the highly decreased NO production in roots (Vandelle and Delledonne 2011). ROS and NO have several roles, first, as signal molecules, second as PCD inducers depending on their concentration (Choudhury et al., 2013).

High salinity induced massive increase in both ROS and NO level in root tips already after one hour. By contrast, simultaneous ROS and NO accumulation was slightly delayed and was detected only at six hour in leaves. Each of the phenomenon can be recognized such as ROS burst and $\mathrm{K}^{+}$efflux leading to increased proteolysis (Demidchik et al., 2014). Importantly, tomato proved to be tolerant to $100 \mathrm{mM} \mathrm{NaCl}$ treatment as we did not detect parallel increase in both ROS and NO and membrane destruction either in leaves or roots.

Roots have an enhanced energy demand at this early stage of salt stress (Ghosh et al., 2014). Therefore, proteolytic enzymes may have essential roles in regulating protein spectrum, protein turnover and protein content of tissues (Yoshimura et al., 2008). Protease inhibitors are also an integral part of PCD regulation. Protease inhibitors may regulate the activity of PLCPs and prevent PCD upon sublethal salt stress (Pernas et al., 2000; van Wyk et al., 2014), whereas Cys proteases may participate int he initiation or execution of PCD.

\subsection{Cys poteases}

\subsubsection{PLCPs}

We detected four PLCPs in the roots and five PLCPs in the leaves that might be activated during salt stress-induced PCD. They are classified as C14 proteases, Solyc04g078540.2.1 belongs to RD21A-like protease subfamily, Solyc04g080960.2.1 belongs to RD19A-like protease, Solyc02g077040.2.1 belongs to SAG12-like proteases and CYP3 is an aleurain-like protease whereas Solyc04g080880.2 belongs to XBCP3-like protease subfamily. Interestingely, we detected PLCPs which were identified only either in roots or leaves and which were detected in both organs. Most of the identified PLCPs originally carry a granulin domain (Fig.21A and Fig.23A). Granulin-containing proteases have been implicated in abiotic stress in the leaves (Koizumi et al., 1993) and in salt stress response in the roots (Hayashi et al., 2001). There are several studies which suggest the roles of aleurains and granulin-containing proteases in early processes of PCD. Arabidopsis RD21 provides immunity against pathogen attack (Shindo et al., 2012) and emerged as a pro-death protease during PCD (Lamp et al., 2013). RD21 is located in pre-vacuole endoplasmic reticulum (ER) bodies and in the vacuole (Hatsugai et al., 2009). Furthermore 
aleurains in leaf and flower tissue, and a XBCP3-like protease in the root tissue play critical roles at early stages of cell death (Funk et al., 2002; Asp et al., 2004, Eason et al., 2005; Avci et al., 2008; Han et al. 2012).

Expression level of the identified proteases increased after 24 hours. At the early stages of PCD probably those proteases are activated which are basically stored as proproteases and they quickly reach their active form due to the salt stress. It is important to note that ABPP gives information only about the activated form of proteases not about their exact protein level. It might be that synthesis of more subsets of Cys proteases is needed to accomplish proteolysis during PCD, therefore, we might have detected overexpression of several genes (CYP3, C14, RD19A and $R D 21 A$ ) at 24 hours (Fig.24).

\subsubsection{VPES}

We confirmed with several tests that VPEs are exclusively targeted by JOPD in tomato. VPE labeling was performed at different pHs, which demonstrated that VPEs only active at acidic $\mathrm{pH}$ and the presence of alkylating agent (IAcAm) or the absence of reducing agent (DTT) inhibited JOPD-labeling (Misas-Villamil et al., 2013). Labeling was competed with YVAD and 1440, two VPE specific inhibitors, but not with E-64 (Sueldo et al., 2014) (Fig.25).

VPEs are responsible for maturation and activation of vacuolar enzymes and are involved in PCD during plant immune response e.g. in tobacco upon bacterial infection or in Arabidopsis during infection with the oomycete pathogen (del Pozo and Lam, 1998; MisasVillamil et al., 2013; Hatsugai et al., 2015). Several abiotic stresses, such as $\mathrm{NaCl}$ - or $\mathrm{H}_{2} \mathrm{O}_{2}$ stress, induce expression of certain VPEs (Deng et al., 2011). Importantly, overexpression of anti-apoptosis genes in tobacco or in rice, such as $\mathrm{BCl}-2$, Ced-9 and $\mathrm{Bl}-1$, suppresses $\mathrm{NaCl}-$ induced PCD and negatively affects the expression level of OsVPE2 and OsVPE3 resulting an increase in tolerance to salt stress in transgenic rice (Deng et al., 2011; Kim et al., 2014). SIBI-1 was downregulated after six hour upon lethal salinity in tomato root tips in contrast to the sublethal salt conditions where it remained slightly upregulated. We found also a transient overexpression of $S I B I-1$ in the root tips of tomato exposed to sublethal salicylic acid treatment (Kovács et al., 2016). Activity of VPEs was revealed as an opposite response in different organs. VPEs are activated in leaves while their activity decreased in roots upon lethal salt stress (Fig.26).

\subsection{Proteasome modification during salt stress}

Unexpectedly, while studying the activity of different subsets of PLCPs, we discovered robust alteration in the activity profile of proteasome catalytic subunits. Both catalytic $\beta 2$ and 
$\beta 5$ subunits shifted to a higher $\mathrm{MW}$ and $\beta 5$ also has a negative $\mathrm{pl}$ shift upon salt stress. The recurrence of a normal proteasome profile at 24 hours upon treatment with $250 \mathrm{mM} \mathrm{NaCl}$ indicates that this change is reversible and occurs concomitantly with PCD (Fig.30B).

The reason for proteasome modification could be an altered preference for substrates. Salt stress induces protein oxidation and an altered proteasome might be required to degrade these oxidized proteins. The three catalytic subunits have different peptidase activity and their modification may cause changes in their activity and specificity.

There are several molecular mechanisms that might underpin MW/pl shifts of catalytic subunits. In animals, standard proteasome subunits are replaced in nascent proteasome complexes by highly homologous $\beta 1 \mathrm{i}, \beta 2 \mathrm{i}$, and $\beta 5 \mathrm{i}$ subunits, which more efficiently produce antigenic peptides in response to infection (Tanaka and Kasahara, 1998) and more efficiently degrade oxidized proteins (Seifert et al., 2010). Replacements by the i-20S proteasome subunits open the central chamber to allow access of more proteins to the catalytic core (Groettrup et al., 2010). Also, the immunoproteasome has reduced caspase-like activity (Ferrington et al., 2012). In tobacco $\beta 1$, $\alpha 3$ and $\alpha 6$ subunits have different isoforms (Suty et al., 2003). We can, however, exclude the mechanism of subunit replacement because the $\beta 2$ and $\beta 5$ proteins with altered $\mathrm{MW} / \mathrm{pl}$ are the same proteins before and after salt stress.

Second, although different genes encoding the different $\beta 5$ isoforms can be excluded, alternative splicing could still result in different $\beta 5$ isoforms from the same gene. In animals, for instance, alternative splicing of transcripts encoding proteasome subunits can alter the activity and substrate specificity of 20 S proteasome (Kawahara et al., 2000).

\subsubsection{Post-translational regulation of the proteasome}

Post-translational modification (PTM) might also be a possible molecular mechanism causing the shift in MW and pl of catalytic subunits. In animals, multiple PTMs have been described for proteasome subunits such as phosphorylation, glycosylation, oxidation, nitrosylation, and ubiquitination (Bose et al., 2004; Ventadour et al., 2007; Zong et al., 2008; Scruggs et al., 2012; Cui et al., 2014). PTMs can regulate the stability of the proteasome, alter the assembly of different subunits and change the degradation pattern of proteasome or activity profile of catalytic subunits (Bose et al., 2004).

First, protein phosphorylation can cause both MW and pl changes (Zong et al., 2008). In plants, phosphorylation is one of the best known and major covalent modifications involved in the regulation of proteins. Phosphorylation of a serine residue in the proteasome a6 subunit has already been studied in rice root tips (Umeda et al., 1997) and phosphorylation likely causes a mass increment of $\beta 1$ din during the induction of defense in tobacco (Suty et al., 2003). There are several predicted phosphorylation sites in catalytic 
subunits. The $\beta 2$ subunit contains $8 \mathrm{Ser}, 5 \mathrm{Thr}, 4 \mathrm{Tyr}$ residues, whereas the $\beta 5$ subunit contains 10 Ser, 1 Thr and 3 Tyr residues. However, phosphatase treatment did not affect the MVB072 activity profile in tomato roots upon $250 \mathrm{mM} \mathrm{NaCl}$ treatment (Fig.34A) suggesting that phosphorylation is not the underlying mechanism of the altered proteasome upon salt stress.

Second, proteasome subunits can be regulated by glycosylation. For instance OGlycosylation reversibly inhibits proteasome function via modification of Rpt2 ATPase in the $19 S$ regulatory particle of the proteasome in animals (Zhang et al., 2003). Likewise, NGlycosylation is a key PTM of specific proteins during osmotic stress adaptation in plants (Koiwa et al. 2003). However, deglycosylation by PNGase or deglycosidase mix had no effect on the MW shift of $\beta 5$ (Fig.34C) indicating that also glycosylation is not the underlying mechanism.

Third, ubiquitination is common on proteasome subunits. Both $\beta 2$ and $\beta 5$ catalytic subunits are ubiquitinated at Lys residues (Ventadour et al., 2007; Kim et al., 2013). However, the predicted MW shift of mono- or polyubiquitinated $\beta 2$ and $\beta 5$ is too large $(>8.5$ $\mathrm{kDa}$ ) to explain the observed $\sim 2 \mathrm{kDa}$ MW shift in the altered proteasome.

Fourth, ROS production leads to accumulation of oxidatively modified proteins (e.g. carbonyl compounds) that alter the function of enzymes (Basset et al., 2002). There is evidence of carbonylation of the 20S proteasome in response to carbon starvation in maize root tips (Basset et al., 2002). We carefully analyzed the MS data but could only uncover Met oxidation which is probably generated ex vivo (Table S1).

Last, RNF could leads to nitrosothiol formation that might target the thiol side chain of Cys residues and generate S-nitrosylation as a possible PTM (Hess et al., 2005). $\beta 2$ has four and $\beta 5$ has two Cys residues which may explain a $2 \mathrm{kDa}$ upon S-nitrosylation. Many additional PTMs are known and they can also be combined in several ways. Also a combination of PTMs might result in the observed $\mathrm{MW} / \mathrm{pl}$ shifts in the activity profile of $\beta 2$ and $\beta 5$ catalytic subunits.

\subsection{Investigation of the role of $A B A$ in response to high salinity}

\subsubsection{Detection of cell viability}

$A B A$ is a key endogenous messenger in plants participating in responses to salinity. Salt stress causes massive transient increments in ABA level resulting in physiological changes in plants (Raghavendra et al., 2010). Tomato mutant with reduced ABA level (sitiens, sit) was investigated upon low (100 $\mathrm{mM} \mathrm{NaCl})$ - and high $(250 \mathrm{mM} \mathrm{NaCl})$ salt stress. It is well known that sitiens is not able to withstand salt stress even if it is a sublethal $\mathrm{NaCl}$ 
concentration for tomato due to their defective ABA production (Flors et al., 2007). It was revealed that severe damages are caused by ABA deficiency and ABA-mutant plants dye within 48 hours already upon $150 \mathrm{mM} \mathrm{NaCl}$ salt exposition (Dunlap and Binzel, 1996).

Importantly, significantly decreased cell viability was observed in sitiens roots upon low salt treatment already after 6 hours. The viability of the wild type roots decreased to $50 \%$ upon $250 \mathrm{mM} \mathrm{NaCl}$ treatment while the viability of sitiens roots was further decreased to $10 \%$ (Fig.35).

ABA controls several mechanism in response to salt stress. Besides regulation of stomatal closure it regulates water flow, specifically by having effects on aquaporins (Parent et al., 2009), induces accumulation of osmoprotectants or activates detoxifying mechanisms (Finkelstein et al., 2013). Indeed, ABA deficiency provokes many cellular damages already at the early stage of salt stress in roots leading to PCD such as oxidative burst or disruption of membrane integrity (Filkenstein and Rock 2002). Salt stress causes a strong electrolyte leakage, especially that of $\mathrm{K}^{+}$from tissues as a consequence of lipid peroxidation (Flors et al., 2007). Increased EL was revealed in roots of both wild type and sitiens mutants upon 250 $\mathrm{mM} \mathrm{NaCl}$ treatment (Fig.36).

\subsubsection{Detection of oxidative burst}

First, we observed highly increased ROS production without salt treatment and ROS level massively increased in sitiens roots while it slightly decreased in wild type roots upon $100 \mathrm{mM}$ salt treatment, however, it significantly decreased upon lethal salt treatment in both genotypes at 6 hours. As basic strong ROS signal was detected in sitiens roots under normal condition and increased ROS level under low salt stress, we suggest that ABA has a crucial role in control of ROS scavenging mechanisms by regulating non-enzymatic and enzymatic antioxidant mechanisms. ABA induces the activity of SOD, CAT, APX and GR in rice (Ye et al., 2011; Zhang et al., 2012; You and Chan 2015) and the production of active oxygen species via PM NADPH-oxidase resulting in the induction of these antioxidant enzymes in maize (Jiang and Zhang 2002) and in cotton under salt stress (Bellaire et al., 2000; Jiang and Zhang 2002). Reduced ABA level can ruin this balance and a low salt stress can induce oxidative damages.

Second, both of $\mathrm{H}_{2} \mathrm{O}_{2}$ content and $\mathrm{NO}$ production decreased in the root tips of sitiens mutants compared to the wild type (Fig.38 and Fig.39). Recently, it was demonstrated that $\mathrm{H}_{2} \mathrm{O}_{2}$ and $\mathrm{ABA}$ are important signals for increasing $\mathrm{Na}^{+}$efflux and water uptake in Gossypium hirsutum L. roots (Kong et al., 2016). Decreased $\mathrm{H}_{2} \mathrm{O}_{2}$ content might be a crucial point in salt susceptibility of sitiens mutants. Interaction between $A B A$ and reactive oxigen and nitrogen species including $\mathrm{H}_{2} \mathrm{O}_{2}$ and $\mathrm{NO}$ is intensively studied. Although, it is already known that $\mathrm{H}_{2} \mathrm{O}_{2}$ 
and NO are essential components of ABA-regulated stomatal closure in a number of species such as Arabidopsis, bean, or in tomato (Garcia-Mata and Lamattina, 2001; Desikan et al., 2002; Desikan et al., 2004; Neill et al., 2002; Bright et al., 2006), it is becoming more apparent that $\mathrm{NO}$ might act downstream of $\mathrm{ABA}$ mediated by $\mathrm{H}_{2} \mathrm{O}_{2}$ in some cases (Lu et al., 2009; Zhang et al., 2009; Hancock and Wilson 2011). Overall, their signalling pathways are complex and it is likely that $A B A$ has a crucial role in regulation of $\mathrm{H}_{2} \mathrm{O}_{2}$ and $\mathrm{NO}$ level in this early stage of PCD in sitiens roots.

\subsubsection{Investigation of protein degradation in sitiens}

Proteolysis is essential part of stress responses and increased proteolytic activity is a main phenomenon of PCD (Trobacher et al., 2006). ABA mutant tomato is more susceptible to salt stress therefore we hypotesized that $A B A$ deficiency could result in increased proteolytic activity in this early stage of PCD. Little is known about the link between ABA deficiency and proteolysis, although there are some previous results that can reinforce our assumption. For instance, ABA plays a regulatory role in maturation and germination of seeds and total proteolytic activity was inhibited by ABA in maize seedlings (Petkova et al., 2003). However, ABA displays different effects on various proteolytic activities, probably depending on its signalling pathway. ABI5 (ABSISIC ACID-INSENSITIVE 5), a bZIP TF, plays an important role in germination and post-germinative growth. $A B I 5$ protein degradation was slowed down in the presence of high level of $A B A$ through proteasome degradation pathway (Lopez-Molina et al., 2001). Trobacher et al. (2013) showed that ABA delayed the accumulation and maturation of SICysEP, a cysteine endopeptidase, which is an indicator of PCD in tomato endosperm. In agreement with previous reports we revealed increased total protease activity in the absence of ABA (Fig.42), importantly, the difference between wild type and sitiens was detected only upon $100 \mathrm{mM} \mathrm{NaCl}$ treatment. Low salt stress reduced protein content (Fig.41) and simultanously, increased proteolytic activity in sitiens roots whereas proteolytic activity was increased in wild type and in the mutants at the same degree under lethal salt condition (Fig.42).

Gelatin-SDS PAGE zymography revealed very remarkable differences in the activity of high MW proteases between wild type and mutant plants. Some of them exhibited increased activity during lethal salt stress in the wild type, whereas reduced activity in sitiens mutants. Others displayed higher basal activity in the mutants, which increased upon $100 \mathrm{mM} \mathrm{NaCl}$ exposure and declined again at $250 \mathrm{mM} \mathrm{NaCl}$ (e.g. MW $70 \mathrm{kDa}$ protein). These data suggest that Cys proteases play minor role in bulk protein degradation in this early phase of salt stress. Howvere, ABPP revealed substantial differences between Cys protease activities of the roots at 34 and $28 \mathrm{kDa}$ in the wild type and mutant plants. These proteases were much 
more active in sitiens mutants under salt stress which suggests that ABA accumulating under salt stress may suppress the activity of specific Cys proteases in the roots of tomato which might be a crucial point in plant defense to survive lower salt stress.

We could demonstrate that there are differences not only in the activity of protease proteins but also in the gene expression level. RD19A was overexpressed in sitiens under $100 \mathrm{mM} \mathrm{NaCl}$ treatment while the xpression of SAG12 increased more significantly upon lethal salt stress in the wild type (Fig.44). 


\section{Summary}

High salinity is one of the major environmental stress factor that reduces growth and limits crop productivity. Depending on the salt concentration, plants can acclimate to high salinity or they can die. If salt stress exceeds a limit and it is persistent, PCD is induced. Thus, it is very important to increase our knowledge about the physiological and molecular background of salt stress. In this study we compared sublethal and lethal salt stress-induced events during the first 24 hours of the salinity stress.

To summarize our results we listed our findings:

1. Overall, the leaves showed delayed response to salt stress in contrast to the roots. Since roots are the primary site of perception of high salt concentrations in the environment, their responses and adaptive behaviour form the first line of defense against stress damage. Decreased viability at six hours upon lethal salt treatment indicates a massive and quick cell death, irreversible loss of membrane integrity, high electrolyte leakage, low $\mathrm{K}^{+} / \mathrm{Na}^{+}$ratio and DNA degradation that is completed within 24 hours compared to sublethal salt treatment that caused a slower loss of viability of root cells.

2. According to ROS burst and NO peaks we are able to clarify if the process turns into cell survival or cell death. Lethal salt stress induced parallel ROS and NO peaks at the beginning of salt exposure in roots in contrast to leaves where NO peak appeared only after six hours together with increased ROS level. High level of ROS causes severe cellular damage and can lead to protein degradation and cell death. Although NO can induce PCD but only with contribution of ROS. Simultaneous alteration of ROS and NO content as a function of time is a crucial point in of organ-specific survival or salinityinduced PCD.

3. High salinity-induced reduction in total protein content appeared only after 24 hours both in leaves and roots, however, it was already slightly reduced earlier in the roots. In parallel with protein degradation increased activity of proteases appears that are implicated in most cellular processes linked with PCD including nutrient re-cycling and selective destruction of misfolded or damaged proteins. Increased protease activity was universal and typical both in the roots and the leaves from six hours under salt stress. 
4. We focused further on the investigation of Cys proteases because they are considered to play a role in the regulation of PCD. Most of the studies focus on their roles in biotic stress whereas little is known about their activity during abiotic stress. Cys proteases might have important role on regulating defense mechanisms or salt-induced PCD which is unrevealed, yet. We discovered increased PLCPs activity from three different subclasses. Four PLCPs in the roots and five PLCPs in the leaves were identified that might have a role during salt stress-induced PCD. Interestingely, we detected PLCPs which were organ-specific and were identified only either in the roots or in the leaves and which were presented in both organs. Interestingly, we revealed organ-specific overexpression of C14, AALP-like, RD19-like proteases that were overexpressed specifically in the leaves. The root-specific RD21A-like protease was overexpressed during salt stress-induced PCD. However, the overexpression of PLCPs occurred typically after 24 hours which can indicate that further protease synthesis is required for PCD execution.

5. We also investigated VPEs, which belong to Cys proteases. VPE is one of the protease subfamilies carrying caspase-like activity. We verified with different labeling conditions that only VPEs were labeled by JOPD1 probe. We were able to detect by ABPP that activity of VPEs are organ-specific in tomato. Significantly increased activity of VPEs was revealed in the leaves after six hours, by contrast, reduced activity of VPEs was revealed in the roots after 24 hours. Previous studies focused only on their role in biotic stress. Here, we demostrated that their activity increased only upon lethal salt stress, thus it can be assumed that they might have a role in salt stress-induced bulk protein degradation and they can also support the maturation of other vacuolar proteases.

6. High salinity altered the proteasome catalytic subunits in the roots while in the leaves it was unaltered. $\beta 2$ and $\beta 5$ subunits were activated upon salt stress-induced PCD which caused a shifted band in the labeling profile. Notably, the activated band shifted to higher MW which could possibly be due to structural modification. Since $\beta 5$ has an acidic pl shift, too, it could be due to phosphorylation or other PTMs. However, the role of phosphorylation and glycosylation in MW changes could not be proved. As the changes of activity profile of PLCPs, VPEs and proteasome catalytic subunits were not detected at sublethal $(100 \mathrm{mM})$ salt concentration, the identified PLCPs and the altered $\beta 2, \beta 5$ catalytic subunits might be involved in PCD at the early stages of high salt stress. Reoccurence of normal proteasome profile at 24 hours upon lethal salt treatment indicates that this change is reversible and confirms that it occurs concomitantly with PCD. 
7. Most prominent alteration between wild type and ABA deficient, sitiens mutant under salt stress is that $100 \mathrm{mM}$, sublethal salt treatment seems to induce PCD in sitiens. ABA deficiency clearly induces sensitivity of tomato against salinity. Basic profile of almost all of the physiological responses was changed including cell viability, ROS content, NO production and protein degradation. Cell viability of the root cells in the mutants significantly declined not only upon $250 \mathrm{mM} \mathrm{NaCl}$ treatment but also upon 100 $\mathrm{mM} \mathrm{NaCl}$ treatment compared to the wild type. Surprisingly, membrane integrity still remained stable upon sublethal treatment in sitiens.

8. Importantly, under normal condition total ROS content was already increased and it became higher upon sublethal salt stress while $\mathrm{H}_{2} \mathrm{O}_{2}$ and $\mathrm{NO}$ content decreased in sitiens compared to wild type. There is a clear correlation between ROS burst, disruption of membrane integrity and protease activation. Interestingly, increased electrolyte leakage is not needed to increase activity of proteases and simultaneously for degradation of proteins induced upon sublethal salt treatment in sitiens roots.

9. It is suggested that while a number of proteases are differentially activated in wild type and sitiens roots, the activities of certain Cys proteases (at $\sim 34$ and $28 \mathrm{kDa}$ ) increases to much higher extent in the mutant under salt stress indicating that ABA may suppress specific proteolytic activities under salinity. Similar tendencies can be found in the case of certain proteases of higher MW, which suggests that ABA plays a crucial role in the inhibition of proteolitic activity under salt stress, especially under low salt concentrations. This might indicate that ABA can have a role in defense mechanism via suppression of special Cys proteases under low salt stress. 


\section{8 Összefoglalás}

A mezőgazdaságban az egyik legnagyobb terméskiesést okozó stresszfajta a sóstressz. Egyre több kutatás foglalkozik különböző fajok sótürésének vizsgálatával, a stressztoleráns fajok szelektálásával, valamint a sóstresszel szembeni rezisztencia fokozásával. Sókoncentrációtól függően a növények képesek védekezni, sikeres akklimatizációt követöen túlélni a környezetükben kialakuló stresszt. Ellenben, ha sóstressz idöben elhúzódik, illetve a sótartalom átlép egy bizonyos koncentrációt, a növényben programozott sejthalál (PCD) indukálódhat.

Munkánk során összehasonlítottuk, hogy milyen fiziológiai, biokémiai és molekuláris biológiai változások figyelhetőek meg a paradicsom növények levelében, illetve gyökerében a szubletális, $100 \mathrm{mM} \mathrm{NaCl}$ - és a letális, PCD-t indukáló, $250 \mathrm{mM} \mathrm{NaCl}$ kezelés hatására.

Munkánk során az alábbi fő eredményeket kaptuk:

1. A vizsgálatok során sóstressz hatására levélben mindig késleltetett változást tapasztaltunk a gyökérben kapott válaszreakciókhoz képest. Mivel a gyökér az elsödleges pont, ahol a növény találkozik és érzékelni képes a kialakult környezeti változást, jelen esetben a sóstresszt, ezért az itt keletkezett válaszok nagymértékben befolyásolják a növény későbbi adaptációját. A gyökér életképességét vizsgálva elmondhatjuk, hogy a $250 \mathrm{mM}$-os $\mathrm{NaCl}$ koncentrációnál már 6 óra elteltével egy masszív, gyors PCD-t figyelhetünk meg, ami 24 órán belül kiteljesedik, összehasonlítva a szubletális sóstressz hatásaival, mely csak 24 óra elteltével csökkentette szignifikánsan a gyökércsúcsok életképességét.

2. A reaktív oxigén formák akkumulációja (ROS robbanás) és NO produkció maximumainak idöbeli összehasonlításával egyértelmüen el tudjuk különíteni, hogy a paradicsomban stressz hatására végbe fog-e menni a PCD, vagy sikeres lesz-e az akklimatizáció. Ugyanis letális sóstressz hatására már az első órában egyidejű ROS és NO csúcsot figyeltünk meg gyökérben, ellentétben a levéllel, ahol az egyidejű ROS és NO növekedést csak 6 óra után detektáltuk. Magas ROS szint sejtszintű károsodásokat okoz, amely fehérje karbonilációhoz, a károsodott fehérjék lebontásához illetve sejthalálhoz vezethet. Habár az NO is képes PCD-t indukálni, ez, in vivo általában csak a ROS egyidejü közremüködésével valósul meg. Feltehetően a magas ROS és NO szint egyidejü megjelenésének fontos szerepe van a sóstresszindukálta PCD indukciójában szövet-specifikus módon. 
3. Letális sóstressz hatására csak 24 óra után imegfigyelhető volt az összfehérje szint csökkenése mind levélben, mind gyökérben, habár a gyökérben enyhe csökkenés már korábban észlelhető volt. Párhuzamosan a fehérje lebontással, összes proteáz aktivitás növekedés volt megfigyelhető, ami a legtöbb PCD alatt lejátszódó sejtszintű folyamattal összeköttetésbe hozható. Fontos szerepe van ennek a N-körforgásban, a nem megfelelő térszerkezetü, misfolded vagy károsodott fehérjék szelektív lebontásában. Általánosan megfigyelhető volt, hogy mind levélben, mind gyökérben 6 óránál fokozódik a proteázok aktivitása sóstressz alatt.

4. A proteáz aktivitás növekedés hátterének mélyebb megismerése érdekében ABPP módszer segítségével tanulmányoztuk a cisztein proteázokat. A legtöbb kutatás a Cys proteázok biotikus stresszben betöltött szerepével foglalkozik és emiatt keveset tudunk az abiotikus, ezen belül is a sóstresszben betöltött szerepükről. A papain-szerű Cys proteázok (PLCP) mind a sóstressz elleni védekezésben, mind a sejthalál indukciójában és végrehajtásában fontos szerepet tölthetnek be. Megnövekedett PLCP aktivitást figyeltünk meg letális sóstressz alatt 6 óránál. Azonostás után megállapítottuk, hogy az aktiválódott cisztein proteázok három különböző PLCP alosztályyból származnak. Négy PLCP-t gyökérben, ötöt levélben azonosítottunk, melyek közül volt amelyik szövetspecifikusan jelent meg. Génexpressziós vizsgálatok kimutatták, hogy a C14, egy AALP-szerü és egy RD19-szerü cisztein proteáz specifikusan levélben, míg az eredetileg is gyökérspecifikusságot mutató egyik RD21Aszerü proteáz gyökérben felülexpresszálódott letális sóstressz hatására 24 óra után. Kései felülexpresszálódást okozhat a növény további proteáz szükséglete. A korai órákban valószínűleg a jelenlévő, inaktivált formában jelenlévő „készenléti” protázok elérik aktivált formájukat és így képesek kifejteni hatásukat. Másodlagos, avagy késleltetett mechanizmusként jelentkezhet a további cisztein proteázok szintéziséhez szükséges génexpresszió fokozódás.

5. Cisztein proteázokon belül külön vizsgáltuk VPE alcsaládot, melyek caspase-1 szerü aktivitással rendelkeznek. Bizonyítottuk a proteáz megjelölésének különböző beállításaival, hogy az alkalmazott próba valóban VPE-ket jelöl. ABPP segítségével kimutattuk, hogy a VPE-k szövetspecifikus aktivitásváltozást mutatnak. 6 óránál szignifikánsan megnőtt az aktivitásuk levélben, míg 24 óránál szignifikáns csökkenést figyeltünk meg gyökérben. Korábbi kutatások a VPE-k biotikus stresszben betöltött szerepére fókuszáltak. Jelen munkában kimutattuk, hogy sóstressz alatt aktivitásuk csak letális sókoncentráció hatására indukálódik, így feltételezhető, hogy szerepük van 
a sósterssz-indukálta protein degradációban, illetve egyéb vakuoláris enzimek aktiválódásában.

6. A letális sóstressz megváltoztatta a proteaszóma katalitikus alegységek aktivitását is 6 óránál gyökérben, levélben nem tapasztaltunk változást. $\beta 2$ és $\beta 5$ katalitikus alegységek aktivitálódtak a sóstressz-induálta PCD alatt, amely mind az alegységek molekulasúlya, mind izoelektromos pontja ( $\mathrm{pl}$ ) eltolódásában jelentkezett a vizsgálatok alatt. Valószínū, hogy a molekulasúlyban és pl értékben történt változás a proteaszóma szerkezetében történt változással együttesen jelentkezik. Mivel a PLCPkben és proteaszóma aktivitásában megfigyelt változások nem jelentkeztek szubletális sóstressz alatt, ezért feltételezhetjük, hogy valamiféle szerepet tölthetnek be a sóstressz-indukálta PCD korai szakaszában. A proteaszóma aktivitásának változása 24 óra elteltével már nem volt tapasztalható, ezért feltételezhetően egy reverzibilis folyamatot fedeztünk fel.

7. A legfontosabb változás az ABA deficiens, sitiens mutánsban a vadtípushoz képest, hogy a szubletális, $100 \mathrm{mM} \mathrm{NaCl}$ kezelés is több olyan folyamatot indukál, melyek PCD-hez vezethetnek. Egyértelműen érzékenyebbé válik a sitiens mutáns alacsonyabb mértékű sóstresszre is. A gyökércsúcsi szövetek életképessége, a ROS tartalom, az NO termelődés és a fehérje lebontás alapvetően más profilt mutattak sitiens gyökérben:. A gyökércsúcs életképessége szignifikánsan lecsökkent nemcsak letális sóstressz, hanem szubletális sóstressz hatására is. Viszont érdekes jelenséget tapasztaltunk a membránok áteresztőképességét vizsgálva, $100 \mathrm{mM} \mathrm{NaCl}$ hatására kontrollhoz hasonló eredményt mutatott a sitiens gyökérszövetek elektrolit kieresztésének (EL) mértéke.

8. Fontos megjegyezni, hogy a mutánsok gyökerében normál körülmények között is már megemelkedett ROS szintet mértünk, ami tovább nőtt 100 mM sókezelés hatására, mialatt a NO tartalom csökkent sitiens gyökérben. Korábban egyértelmü kapcsolatot fedeztek fel ROS robbanás, a plazmamembrán áteresztőképességének megváltozása és a proteázok aktiválódása között. Meglepő módon, ABA hiány esetén a megnövekedett EL nem szükséges a proteázok aktivitásához. Ugyanis vadtípushoz képest sitiens gyökérben szubletális sókoncentráció alatt az EL nem változott, viszont szignifikánsan csökkent a fehérjetartalom és megnövekedett az összes proteáz aktivitást. 
9. Számos proteáz különbözőképpen aktiválódik mind a vadtípus, mind a sitiens gyökérben. Fontos megjegyezni, hogy sóstressz hatására bizonyos cisztein proteázok ( 34 és 28 kDa-nál) aktivitása nagymértékben megnövekszik sitiens gyökerében, ami utalhat arra, hogy letális sóstressz hatására az ABS specifikusan gátolhatja bizonyos cisztein proteázok aktivitását, ezáltal a fehérje degradálódást. Hasonló tendenciák figyelhetők meg magasabb molekulatömegü proteázok esetében is, ami tovább erősíti azon feltételezésünket, miszerint az ABS-nak jelentős szerepe lehet a proteolízis gátlásában, különösképpen szubletális sóstressz hatására ezzel elősegítve a növény túlélését alacsony sóstressz alatt. 


\section{References}

Acosta-Motos JR, Dias-Vivancos P, Álvarez S, Fernández-García N, Sánchez-Blanco MJ and Hernández JA (2015) NaCl-induced physiological and biochemical adaptative mechanismsin the ornamental Myrtus communis L. plants. J Plant Physiol 183:41-51.

Affenzeller MJ, Darehshouri A, Andosch A, Lütz C and Lütz-Meindl U (2009) Salt stress-induced cell death in the unicellular green alga Micrasterias denticulata. $J$ Exp Bot 60:939-954.

Ahmad R, Zuily-Fodil Y, Passaquet C, Bethenod O, Roche R and Repellin A (2014) Identification and characterization of MOR-CP, a cysteine protease induced by ozone and developmental senescence in maize (Zea mays L.) leaves. Chemosphere 108:245-250.

Ahmed SU, Rojo E, Kovaleva V, Venkataraman S, Dombrowski JE,Matsuoka K and Raikhel NV (2000) The plant vacuolar sorting receptor AtELP is involved in transport of $\mathrm{NH}(2)$-terminal propeptide-containing vacuolar proteins in Arabidopsis thaliana. J Cell Biol 149:1335-1344.

Aki M, Shimbara N, Takashina M, Akiyama K, Kagawa S, Tamura T, Tanahashi N, Yoshimura T, Tanaka K and Ichihara A (1994) Interferon-gamma induces different subunit organizations and functional diversity of proteasomes. J Biochem 115:257-269.

Alcázar R, Cuevas JC, Patrón M, Altabella T and Tiburcio AF (2006) Abscisic acid modulates polyamine metabolism under water stress in Arabidopsis thaliana. Plant Physiol 128:448-455.

Andronis EA and Roubelakis-Angelakis KA (2010) Short-term salinity stress in tobacco plants leads to the onset of animal-like PCD hallmarks in planta in contrast to long-term stress. Planta 231:437-448.

Apse MP, Aharon GS, Snedden WA and Blumwald E (1999) Salt tolerance conferred by overexpression of a vacuolar $\mathrm{Na}^{+} / \mathrm{H}^{+}$antiport in Arabidopsis. Science 285:1256-1258.

Arfan M, Athar HR and Ashraf M (2007) Does exogenous application of salicylic acid through the rooting medium modulate growth and photosynthetic capacity in differently adapted spring wheat cultivated under salt stress? J Plant Physio/6:685-694.

Asp T, Bowra S, Borg S and Holm PB (2004) Molecular cloning, functional expression in Escherichia coli and enzymatic characterisation of a cysteine protease from white clover (Trifolium repens). Biochim Biophys Acta 1699:111-122.

Avci U, Petzold HE, Ismail IO, Beers EP and Haigler CH (2008) Cysteine proteases XCP1 and XCP2 aid micro-autolysis within the intact central vacuole during xylogenesis in Arabidopsis roots. Plant J 56:303-315. 
Bagniewska-Zadworna A and Arasimowicz-Jelonek M (2016) The mystery of underground death: cell death in roots during ontogeny and in response to environmental factors. Plant Biology 18:171-184.

Barry CS, Aldridge GM, Herzog G, Ma Q, McQuinn RP, Hirschberg J and Giovannoni JJ (2012) Altered chloroplast development and delayed fruit ripening caused by mutations in a zinc metalloprotease at the lutescent2 locus of tomato. Plant Physiol 159:1086-1098.

Basset G, Raymond P, Malek L and Brouquisse R (2002) Changes in the expression and the enzymatic properties of the $20 \mathrm{~S}$ proteasome in sugar-starved maize roots. Evidence for an in vivo oxidation of the proteasome. Plant Physiol 128:1149-1162.

Baxter A, Mittler R and Suzuki N (2013) ROS as key players in plant stress signalling. $J$ Exp Bot 65:1229-1240.

Beers EP, Woffenden BJ and Zhao C (2000) Plant proteolytic enzymes: possible roles during programmed cell death. Plant Mol Biol 44:399-415.

Beers EP, Jones AM and Dickerman AW (2004) The S8 serine, C1A cysteine and A1 aspartic protease families in Arabidopsis. Phytochemistry 65:43-58.

Bellaire BA, Carmody J, Braud J, Gossett DR, Banks SW, Lucas MC, Fowler TE (2000) Involvement of abscisic acid-dependent and -independent pathways in the upregulation of antioxidant enzyme activity during $\mathrm{NaCl}$ stress in cotton callus tissue. Free Rad Res 33:531545.

Ben-Nissan G and Sharon M (2014) Regulating the 20 S proteasome ubiquitinindependent degradation pathway. Biomolecules 4:862-884.

Berger D and Altmann T (2000) A subtilisin-like serine protease involved in the regulation of stomatal density and distribution in Arabidopsis thaliana. Genes Dev 14:11191131.

Berkowitz O, De Clercq I, Van Breusegem F and Whelan J (2016) Interaction between hormonal and mitochondrial signalling during growth, development and in plant defence responses. Plant Cell Environ 39:1127-1139.

Biasini M, Bienert S, Waterhouse A, Arnold K, Studer G, Schmidt T, Kiefer F, Gallo Cassarino T, Bertoni M, Bordoli L and Schwede T (2014) SWISS-MODEL: modelling protein tertiary and quaternary structure using evolutionary information. Nucleic Acids Res 42:W252258.

Bitrián M, Zarza X, Altabella T, Tiburcio AF and Alcázar R (2012) Polyamines under abiotic stress: metabolic crossroads and hormonal crosstalks in plants. Metabolites 2:516528.

Blumwald E (2000) Sodium transport and salt tolerance in plants. Curr Opin Cell Biol 12:431-434. 
Bombarely A, Menda N, Tecle IY, Buels RM, Strickler S, Fischer-York T, Pujar A, Leto J, Gosselin J and Mueller LA (2011) The Sol Genomics Network (solgenomics.net): growing tomatoes using Perl. Nucleic Acids Res 39:D1149-1155.

Bonneau L, Ge Y, Drury GE and Gallois P (2008) What happened to plant caspases? J Exp Bot 59:491-499.

Bose S, Stratford FLL, Broadfoot KI, Mason GGF and Rivett AJ (2004) Phosphorylation of $20 S$ proteasome alpha subunit C8 ( $\alpha 7)$ stabilizes the $26 S$ proteasome and plays a role in the regulation of proteasome complexes by $\mathrm{y}$-interferon. Biochem J 378:177-184.

Boudsocq M, Droillard MJ, Barbier-Brygoo H and Laurière C (2007) Different phosphorylation mechanisms are involved in the activation of sucrose non-fermenting 1 related protein kinases 2 by osmotic stresses and abscisic acid. Plant Mol Biol 63:491-503.

Bradford MM (1976) A rapid and sensitive method for the quantitation of microgram quantities of protein utilizing the principle of protein-dye binding. Anal Biochem 72:248-254.

Bright J, Desikan R, Hancock JT, Weir IS and Neill SJ (2006) ABA-induced NO generation and stomatal closure in Arabidopsis are dependent on $\mathrm{H}_{2} \mathrm{O}_{2}$ synthesis. Plant $J$ 45:113-122.

Buchanan-Wollaston V, Page T, Harrison E, Breeze E, Lim PO, Nam HG, Lin JF, Wu SH, Swidzinski J, Ishizaki K and Leaver CJ (2005) Comparative transcriptome analysis reveals significant differences in gene expression and signalling pathways between developmental and dark/starvation-induced senescence in Arabidopsis. Plant J 42:567-585.

Cabot C., Sibole JV, Barcelo J and Poschenrieder C (2009) Abscisic acid decreases leaf $\mathrm{Na}^{+}$exclusion in salt-treated Phaseolus vulgaris L. J Plant Growth Regul 28:187-192.

Camejo D, Romero-Puertas Mdel C, Rodríguez-Serrano M, Sandalio LM, Lázaro JJ, Jiménez A and Sevilla F (2013) Salinity-induced changes in S-nitrosylation of pea mitochondrial proteins. J Proteomics 79:87-99.

Cascio P, Hilton C, Kisselev AF, Rock KL and Goldberg AL (2001) 26S proteasomes and immunoproteasomes produce mainly $\mathrm{N}$ - extended versions of an antigenic peptide. EMBO J 20:2357-2366.

Cheeseman JM (2007) Hydrogen peroxide and plant stress: a challenging relationship. Plant Stress 1:4-15.

Chen G, Bi YR and Li N (2005) EGY1 encodes a membrane-associated and ATPindependent metalloprotease that is required for chloroplast development. Plant $J$ 41:364375.

Chen Z, Pottosin II, Cuin TA, Fuglsang AT, Tester M, Jha D, Zepeda-Jazo I, Zhou M, Palmgren MG, Newman IA and Shabala S (2007) Root plasma membrane transporters controlling $\mathrm{K}^{+} / \mathrm{Na}^{+}$homeostasis in salt-stressed barley. Plant Physiol 145:1714-1725. 
Chen ZJ and Sun LJ (2009) Non-proteolytic functions of ubiquitin in cell signaling. Mol Cell 33:275-286.

Cho SK, Ryu MY, Song C, Kwak JM and Kim WT (2008) Arabidopsis PUB22 and PUB23 are homologous U-Box E3 ubiquitin ligases that play combinatory roles in response to drought stress. Plant Cell 20:1899-1914.

Chomczynski P and Sacchi N (1987) Single-step method of RNA isolation by acid guanidinium thiocyanate-phenol-chloroform extraction. Anal Biochem 162:156-159.

Choudhury S, Panda P, Sahoo L and Panda SK (2013) Reactive oxygen species signaling in plants under abiotic stress. Plant Signal Behav 8:e23681.

Coffeen WC and Wolpert TJ (2004) Purification and characterization of serine proteases that exhibit caspase-like activity and are associated with programmed cell death in Avena sativa. Plant Cell 16:857-873.

Correa-Aragunde N, Foresi $N$ and Lamattina $L$ (2015) Nitric oxide is a ubiquitous signal for maintaining redox balance in plant cells: regulation of ascorbate peroxidase as a case study. J Exp Bot 66:2913-21.

Coux O (1996) Structure and functions of the 20S and 26S proteasomes. Annu Rev Biochem 65:801-847.

Cox J, Gmünder H, Hohn A and Rehrauer H (2005) Generation and validation of a reference system for toxicogenomics DNA microarray experiments. In Handbook of Toxicogenomics pp.185-200.

Cox J, Neuhauser N, Michalski A, Scheltema RA, Olsen JV and Mann M (2011) Andromeda: a peptide search engine integrated into the MaxQuant environment. $J$ Proteome Res 10:1794-1805.

Cox J, Hein MY, Luber CA, Paron I, Nagaraj N and Mann M (2014) Accurate proteomewide label-free quantification by delayed normalization and maximal peptide ratio extraction, termed MaxLFQ. Mol Cell Proteomics 13:2513-2526.

Cramer GR, Urano K, Delrot S, Pezzotti M and Shinozaki K (2011) Effects of abiotic stress on plants: a systems biology perspective. BMC Plant Biology 11:163.

Cravatt BF, Wright AT and Kozarich JW (2008) Activity-based protein profiling: from enzyme chemistry to proteomic chemistry. Annu Rev Biochem 77:383-414.

Cui Z, Scruggs SB, Gilda JE, Ping P and Gomes AV (2014) Regulation of cardiac proteasomes by ubiquitination, SUMOylation, and beyond. J Mol Cell Cardiol 71:32-42.

Dahan J, Etienne P, Petitot AS, Houot V, Blein JP and Suty L (2001) Cryptogein affects expression of $\alpha 3 f$, $\alpha 6$ and $\beta 1$ proteasome subunits encoding gene in tobacco. $J$ Exp Bot 52:1947-1948. 
Daneri-Castro SN, Chandrasekar B, Grosse-Holz FM, van der Hoorn RA and Roberts TH (2016) Activity-based protein profiling of hydrolytic enzymes induced by gibberellic acid in isolated aleurone layers of malting barley. FEBS Lett 590:2956-2962.

Deb A, Grewal RK and Kundu S (2016) Regulatory cross-talks and cascades in rice hormone biosynthesis pathways contribute to stress signaling. Front Plant Sci 7:1303.

Delledonne M, Zeier J, Marocco A and Lamb C (2001) Signal interactions between nitric oxide and reactive oxygen intermediates in the plant hypersensitive disease resistance response. Proc Nat Acad Sci USA 98:13454-13459.

Delorme VG, McCabe PF, Kim DJ and Leaver CJ (2000) A matrix metalloproteinase gene is expressed at the boundary of senescence and programmed cell death in cucumber. Plant Physiol 123:917-927.

del Pozo O and Lam E (1998) Caspases and programmed cell death in the hypersensitive response of plants to pathogens. Curr Bio/ 8:1129-1132.

Demidchik V, Cuin TA, Svistunenko D, Smith SJ, Miller AJ, Shabala S, Sokolik A and Yurin V (2010) Arabidopsis root $\mathrm{K}^{+}$-efflux conductance activated by hydroxyl radicals: singlechannel properties genetic basis and involvement in stress-induced cell death. J Cell Sci 123:1468-1479.

Demidchik V, Straltsova D, Medvedev SS, Pozhvanov GA, Sokolik A and Yurin V (2014) Stress-induced electrolyte leakage: the role of $\mathrm{K}^{+}$-permeable channels and involvement in programmed cell death and metabolic adjustment. J Exp Bot 65:1259-70.

Deng M, Bian H, Xie Y, Kim Y, Wang W, Lin E, Zeng Z, Guo F, Pan J, Han N, Wang J, Qian $Q$ and Zhu M (2011) Bcl-2 suppresses hydrogen peroxide-induced programmed cell death via OsVPE2 and OsVPE3, but not via OsVPE1 and OsVPE4, in rice. FEBS $J$ 278:4797-810.

Desikan R, Griffiths R, Hancock J and Neill S (2002) A new role for an old enzyme: nitrate reductase-mediated nitric oxide generation is required for abscisic acid-induced stomatal closure in Arabidopsis thaliana. Proc Nat Acad Sci USA 99:16314-16318.

Desikan R, Cheung K, Clarke A, Goulding S, Sagi M, Fluhr R, Rock C, Hancock JT and Neill SJ (2004) Hydrogen peroxide is a common signal for darkness- and ABA-induced stomatal closure in Pisum sativum. Funct Plant Biol 31:913-920.

Diaz-Mendoza M, Velasco-Arroyo B, Santamaria ME, González-Melendi P, Martinez M and Diaz I (2016) Plant senescence and proteolysis: two processes with one destiny. Genet Mol Biol 39:329-338.

Dodd IC (2013) Abscisic acid and stomatal closure: a hydraulic conductance conundrum? New Phytol 197:6-8.

Dunlap JR and Binzel ML (1996) $\mathrm{NaCl}$ reduces indole-3-acetic acid levels tomato plants independent of stress-induced. Plant Phys 2:379-384. 
Eason JR, Ryan DJ, Watson LM, Hedderley D, Christey MC, Braun RH and Coupe SA (2005) Suppression of the cysteine protease, aleurain, delays floret senescence in Brassica oleracea. Plant Mol Biol 57:645-657.

Ellouzi H, Ben Hamed K, Hernández I, Cela J, Müller M, Magné C, Abdelly $C$ and Munné-Bosch S (2014) A comparative study of the early osmotic, ionic, redox and hormonal signaling response in leaves and roots of two halophytes and a glycophyte to salinity. Planta 240:1299-1317.

Evans A, Hall D, Pritchard J and Newbury HJ (2012) The roles of the cation transporters $\mathrm{CHX} 21$ and $\mathrm{CHX} 23$ in the development of Arabidopsis thaliana. $J$ Exp Bot 63:59-67.

Evers D, Legay S, Lamoureux D, Hausman JF, Hoffmann L and Renaut J (2012) Towards a synthetic view of potato cold and salt stress response by transcriptomic and proteomic analyses. Plant Mol Biol 78:503-514.

Ferrington DA and Gregerson DS (2012) Immunoproteasomes: structure, function, and antigen presentation. Prog Mol Biol Transl Sci 109:75-112.

Finkelstein RR and Rock CD (2002) Abscisic acid biosynthesis and response. Arabidopsis Book 1.

Finkelstein R (2013) Abscisic acid synthesis and response. Arabidopsis Book 11:e0166.

Flors V, Paradís M, García-Andrade J, Cerezo M, González-Bosch C and GarcíaAgustín P (2007) A tolerant behavior in salt-sensitive tomato plants can be mimicked by chemical stimuli. Plant Signal Behav 2:50-7.

Flowers TJ, Troke PF and Yeo AR (1977) The mechanism of salt tolerance in halophytes. Annu Rev Plant Phys 28:89-121.

Flowers TJ (2004) Improving crop salt tolerance. J Exp Bot 55:307-319.

Flowers TJ and Colmer TD (2015) Plant salt tolerance: adaptations in halophytes. Ann Bot 115:327-331.

Foolad MR and Lin GY (1997) Genetic potential for salt tolerance during germination in Lycopersicon species. HortScience 32:296-300.

Foolad MR (2004) Recent advances in genetics of salt tolerance in tomato. Plant Cell Tiss Org 76:101-119.

Foyer $\mathrm{CH}$ and Noctor G (2011) Ascorbate and glutathione: the heart of the redox hub. Plant Physiol 155:2-18.

Fricke W, Akhiyarova G, Veselov D and Kudoyarova G (2004) Rapid and tissuespecific changes in $A B A$ and in growth rate in response to salinity in barley leaves. $J$ Exp Bot 55:1115-1123. 
Friedman DB (2007) Quantitative proteomics for two-dimensional gels using difference gel electrophoresis. Methods Mol Biol 367:219-239.

Fukuda A, Nakamura A, Tagiri A, Tanaka H, Miyao A, Hirochika H and Tanak Y (2004) Function, intracellular localization and the importance in salt tolerance of a vacuolar $\mathrm{Na}^{+} / \mathrm{H}^{+}$ antiporter from rice. Plant Cell Physiol 45:146-59.

Funk V, Kositsup B, Zhao CS and Beers EP (2002) The Arabidopsis xylem peptidase $\mathrm{XCP} 1$ is a tracheary element vacuolar protein that may be a papain ortholog. Plant Physiol 128:84-94.

Gadjev I, Vanderauwera S, Gechev TS, Laloi C, Minkov IN, Shulaev V, Apel K, Inzé D, Mittler R and Van Breusegem F (2006) Transcriptomic footprints disclose specificity of reactive oxygen species signaling in Arabidopsis. Plant Physiol 141:436-45.

Gadjev I, Stone MJ and Tsanko SG (2008) Programmed cell death in plants: new insights into redox regulation and the role of hydrogen peroxide. Int Rev Cell Mol Biol 270:87144.

García-Mata C and Lamattina L (2001) Nitric oxide induces stomatal closure and enhances the adaptive plant responses against drought stress. Plant Physiol 126:1196-1204.

Garzia-Lorenzo (2007) The role of proteases in plant development. Umea ISBN:97891-7264-422-9.

Ge X, Dietrich C, Matsuno M, Li G, Berg H and Xia Y (2005) An Arabidopsis aspartic protease functions as an anti-cell-death component in reproduction and embryogenesis. EMBO Rep 6:282-288.

Gémes K, Poór P, Horváth E, Kolbert Z, Szopkó D, Szepesi A and Tari I (2011) Crosstalk between salicylic acid and $\mathrm{NaCl}$-generated reactive oxygen species and nitric oxide in tomato during acclimation to high salinity. Physiol Plantarum 142:179-92.

Ghanem ME, Albacete A, Martínez-Andújar C, Acosta M, Romero-Aranda R, Dodd IC, Lutts $S$ and Pérez-Alfocea F (2008) Hormonal changes during salinity-induced leaf senescence in tomato (Solanum lycopersicum L.). J Exp Bot 59:3039-3050.

Ghosh D and $\mathrm{Xu} J(2014)$ Abiotic stress responses in plant roots: a proteomics perspective. Front Plant Sci 5:6.

Giannattasio S, Atlante A, Antonacci L, Guaragnella N, Lattanzio P, Passarella S and Marra E (2008) Cytochrome $c$ is released from coupled mitochondria of yeast en route to acetic acid-induced programmed cell death and can work as an electron donor and a ROS scavenger. FEBS Lett 582:1519-1525.

Gill SS, Anjum NA, Gill R and Tuteja N (2016) Abiotic stress signaling in plants-an overview. In book: Abiotic stress response in plants, $1^{\text {st }}$ edition. Wiley Wiley-VCH Verlag $\mathrm{GmbH} \&$ Co. Weinheim, Germany. pp.3-22 
Gill SS and Tuteja N (2010a) Polyamines and abiotic stress tolerance in plants. Plant Sig Behav 5:26-33.

Gill SS and Tuteja N (2010b) Reactive oxygen species and antioxidant machinery in abiotic stress tolerance in crop plants. Plant Physiol Biochem 48:909-30.

Goldberg AL and Dice JF (1974) Intracellular protein degradation in mammalian and bacterial cells. Annu Rev Biochem 43:835-869.

Goldberg AL (2003) Protein degradation and protection against misfolded or damaged proteins. Nature 426:895-899.

Golldack D, Popova OV and Dietz KJ (2002) Mutation of the matrix metalloproteinase At2-MMP inhibits growth and causes late flowering and early senescence in Arabidopsis. J Biol Chem 277:5541-5547.

Golldack D, Li C, Mohan H and Probst N (2014) Tolerance to drought and salt stress in plants: unraveling the signaling networks. Front Plant Sci 5:151.

González-García MP, Rodríguez D, Nicolás C, Rodríguez PL, Nicolás G and Lorenzo O (2003) Negative regulation of abscisic acid signaling by the Fagus sylvatica FsPP2C1 plays a role in seed dormancy regulation and promotion of seed germination. Plant Physiol 133:135-144.

Greenbaum D, Medzihradszky KF, Burlingame A and Bogyo M (2000) Epoxide electrophiles as activity-dependent cysteine protease profiling and discovery tools. Chemistry and Biology 7:569-581.

Grigoreva TA, Tribulovich VG, Garabadzhiu AV, Melino G and Melino NA (2015) The $26 \mathrm{~S}$ proteasome is a multifaceted target for anti-cancer therapies. Oncotarget 6:2473324749 .

Groettrup M, Kirk CJ and Basler M (2010) Proteasomes in immune cells: more than peptide producers? Nat Rev Immunol 10:73-78.

Groll M, Schellenberg B, Bachmann AS, Archer CR, Huber R, Powell TK, Lindow S, Kaiser M and Dudler R (2008) A plant pathogen virulence factor inhibits the eukaryotic proteasome by a novel mechanism. Nature 452:755-758.

Gu C, Kolodziejek I, Misas-Villamil J, Shindo T, Colby T, Verdoes M, Richau KM, Schmidt J, Overkleeft HS and Van der Hoorn RAL (2010) Proteasome activity profiling: a simple, robust and versatile method revealing subunit-selective inhibitors and cytoplasmic, defense induced proteasome activities. Plant J 62:160-170.

Grudkowska M and Zagdańska B (2010) Acclimation to frost alters proteolytic response of wheat seedlings to drought. J Plant Physiol 167:1321-1327.

Gu C, Shabab M, Strasser R, Wolters PJ, Shindo T, Niemer M, Kaschani F, Mach L and van der Hoorn RAL (2012) Post-translational regulation and trafficking of the granulincontaining protease RD21 of Arabidopsis thaliana. PLoS One 7:e32422. 
Guo Y, Cai Z and Gan S (2004) Transcriptome of Arabidopsis leaf senescence. Plant Cell Environ 27:521-549.

Gupta KJ and Igamberdiev AU (2011) The anoxic plant mitochondrion as a nitrite: NO reductase. Mitochondrion 11:537-543.

Habib H and Fazili KM (2007) Plant protease inhibitors: a defense strategy in plants. Biotechnol Mol Biol Rev 2:68-85.

Han JJ, Lin W, Oda Y, Cui KM, Fukuda H and He XQ (2012) The proteasome is responsible for caspase-3-like activity during xylem development. Plant J 72:129-141.

Hancock JT, Neill SJ and Wilson ID (2011) Nitric oxide and ABA in the control of plant function. Plant Sci 181:555-559.

Hardin SC, Larue CT, Oh MH, Jain V and Huber SC (2009) Coupling oxidative signals to protein phosphorylation via methionine oxidation in Arabidopsis. Biochem J 422:305-312.

Hasegawa PM, Bressan RA, Zhu JK and Bohnert HJ (2000) Plant cellular and molecular responses to high salinity. Annu Rev Plant Phys 51:463-499.

Hatsugai N, Kuroyanagi M, Yamada K, Meshi T, Tsuda S, Kondo M, Nishimura M and Hara-Nishimura I (2004) A plant vacuolar protease, VPE, mediates virus-induced hypersensitive cell death. Science 305:855-858.

Hatsugai N, Iwasaki S, Tamura K, Kondo M, Fuji K, Ogasawara K, Nishimura M and Hara-Nishimura I (2009) A novel membrane fusion-mediated plant immunity against bacterial pathogens. Genes Dev 23:2496-2506.

Hatsugai N, Yamada K, Goto-Yamada S and Hara-Nishimura I (2015) Vacuolar processing enzyme in plant programmed cell death. Front Plant Sci 6:234.

Hauske P, Ottmann C, Meltzer M, Ehrmann M and Kaiser M (2008) Allosteric regulation of proteases. Chembiochem 9:2920-2928.

Havlová M, Dobrev PI, Motyka V, Storchová H, Libus J, Dobrá J, Malbeck J, Gaudinová A and Vanková R (2008) The role of cytokinins in responses to water deficit in tobacco plants over-expressing trans-zeatin O-glucosyltransferase gene under $35 \mathrm{~S}$ or SAG12 promoters. Plant Cell Environ 31:341-53.

Hayashi Y, Yamada K, Shimada T, Matsushima R, Nishizawa NK, Nishimura M and Hara-Nishimura I (2001) A proteinase-storing body that prepares for cell death or stresses in the epidermal cells of Arabidopsis. Plant Cell Physiol 42:894-899.

Hayata Q, Hayata S, Irfana M and Ahmadb A (2010) Effect of exogenous salicylic acid under changing environment: A review. Environ Exp Bot 68:14-25.

Hess DT, Matsumoto A, Kim SO, Marshall HE and Stamler JS (2005) Protein Snitrosylation: purview and parameters. Nat Rev Mol Cell Biol 6:150-166. 
Hoeberichts FA, ten Have A and Woltering EJ (2003) A tomato metacaspase gene is upregulated during programmed cell death in Botrytis cinerea-infected leaves. Planta 217:517-522.

Hopkins WG and Hüner NPA (2009) Introduction to plant physiology, $4^{\text {th }}$ edition. John Wiley \& Sons, Inc. ISBN 978-0-470-24766-2.

Hoque TS, Hossain MA, Mostofa MG, Burritt DJ, Fujita M and Tran LS (2016) Methylglyoxal: an emerging signaling molecule in plant abiotic stress responses and tolerance. Front Plant Sci 13:13-41.

Horváth E, Brunner Sz, Bela K, Papdi Cs, Szabados L, Tari I and Csiszár J (2015) Exogenous salicylic acid-triggered changes in the glutathione transferases and peroxidases are key factors in the successful salt stress acclimation of Arabidopsis thaliana. Funct Plant Biol 42:1129-1140.

Hsiao TC and Xu LK (2000) Sensitivity of growth of roots versus leaves to water stress: biophysical analysis and relation to water transport. $J$ Exp Bot 51:1595-1616.

Huh GH, Damsz B, Matsumoto TK, Reddy MP, Rus AM, Ibeas JI, Narasimhan ML, Bressan RA and Hasegawa PM (2002) Salt causes ion disequilibrium-induced programmed cell death in yeast and plants. Plant $J$ 29:649-659.

Ilyas M, Hörger AC, Bozkurt TO, van den Burg HA, Kaschani F, Kaiser M, Belhaj K, Smoker M, Joosten MH, Kamoun S and van der Hoorn RAL (2015) Functional divergence of two secreted immune proteases of tomato. Curr Biol 25:2300-2306.

Javid MG, Sorooshzadeh A, Moradi F, Sanavy SAMM and Allahdadi I (2011) The role of phytohormones in alleviating salt stress in crop plants. Aust J Crop Sci 5:726-734.

Jeong JS, Kim YS, Baek KH, Jung H, Ha SH, Do Choi Y, Kim M, Reuzeau C and Kim JK (2010) Root-specific expression of OsNAC10 improves drought tolerance and grain yield in rice under field drought conditions. Plant Physiol 153:185-97.

Ji H, Pardo JM, Batelli G, Van Oosten MJ, Bressan RA and Li X. (2013) The Salt Overly Sensitive (SOS) pathway: established and emerging roles. Mol Plant 6:275-86.

Jia $\mathrm{H}$ and Lu C (2003) Effects of abscisic acid on photoinhibition in maize plants. Plant Science 165:1403-1410.

Jia W, Wang Y, Zhang S and Zhang J (2002) Salt-stress-induced ABA accumulation is more sensitively triggered in roots than in shoots. J Exp Bot 53:2201-2206.

Jiang M and Zhang J (2002) Involvement of plasma-membrane NADPH oxidase in abscisic acid- and water stress-induced antioxidant defense in leaves of maize seedlings. Planta 215:1022-1030.

Kaschani F, Gu C, Niessen S, Hoover H, Cravatt BF and van der Hoorn RAL (2009b) Diversity of serine hydrolase activities of unchallenged and botrytis-infected Arabidopsis thaliana. Mol Cell Proteomics 8:1082-1093. 
Kasuga M, Liu Q, Miura S, Yamaguchi-Shinozaki K and Shinozaki K (1999) Improving plant drought, salt, and freezing tolerance by gene transfer of a single stress-inducible transcription factor. Nat Biotechnol 17:287-91.

Kawahara H, Kasahara M, Nishiyama A, Ohsumi K, Goto T, Kishimoto T, Saeki Y, Yokosawa H, Shimbara N, Murata S, Chiba T, Suzuki K and Tanaka K (2000) Developmentally regulated, alternative splicing of the Rpn10 gene generates multiple forms of $26 \mathrm{~S}$ proteasomes. EMBO J 19:4144-4153.

Kidrič M, Kos J and Sabotič J (2014) Proteases and their endogenous inhibitors in the plant response to abiotic stress. Bot Serbica 38:139-158.

Kim DY, Scalf M, Smith LM and Vierstra RD (2013) Advanced proteomic analyses yield a deep catalog of ubiquitylation targets in Arabidopsis. Plant Cell 25:1523-1540.

Kim Y, Wang M, Bai Y, Zeng Z, Guo F, Han N, Bian H, Wang J, Pan J and Zhu M (2014) Bcl-2 suppresses activation of VPEs by inhibiting cytosolic $\mathrm{Ca}^{2+}$ level with elevated $\mathrm{K}^{+}$efflux in NaCl-induced PCD in rice. Plant Physiol Biochem 80:168-75.

Kinoshita T, Yamada K, Hiraiwa N, Kondo M, Nishimura M and Hara-Nishimura I (1999) Vacuolar processing enzyme is up-regulated in the lytic vacuoles of vegetative tissues during senescence and under various stressed conditions. Plant J 19:43-53.

Klare N, Seeger M, Janek K, Jungblut PR and Dahlmann B (2007) Intermediate-type $20 S$ proteasomes in HeLa Cells: "Asymmetric" subunit composition, diversity and adaptation. J Mol Biol 373:1-10.

Knight $\mathrm{H}$ and Knight MR (2001) Abiotic stress signalling pathways: specificity and cross-talk. Trends Plant Sci 6:262-7.

Kohli A, Sreenivasulu N, Lakshmanan P and Kumar PP (2013) The phytohormone crosstalk paradigm takes center stage in understanding how plants respond to abiotic stresses. Plant Cell Rep 32:945-957.

Koiwa H, Li F, McCully MG, Mendoza I, Koizumi N, Manabe Y, Nakagawa Y, Zhu J, Rus A, Pardo JM, Bressan RA and Hasegawa PM (2003). The STT3a subunit isoform of the Arabidopsis oligosaccharyltransferase controls adaptive responses to salt/osmotic stress. Plant Cell 15:2273-2284.

Koizumi M, Yamaguchi-Shinozaki K, Tsuji H and Shinozaki K (1993) Structure and expression of two genes that encode distinct drought-inducible cysteine proteinases in Arabidopsis thaliana. Gene 129:175-182.

Kołodziejek I and van der Hoorn RAL (2010) Mining the active proteome in plant science and biotechnology. Curr Opin Biotechnol 21:225-33.

Kolodziejek I, Misas-Villamil JC, Kaschani F, Clerc J, Gu C, Krahn D, Niessen S, Verdoes M, Willems LI, Overkleeft HS, Kaiser M and van der Hoorn RAL (2011) Proteasome 
activity imaging and profiling characterizes bacterial effector syringolin A. Plant Physiol 155:477-489.

Kong X, Luo Z, Dong $\mathrm{H}$, Eneji AE and Li W (2016) $\mathrm{H}_{2} \mathrm{O}_{2}$ and ABA signaling are responsible for the increased $\mathrm{Na}^{+}$efflux and water uptake in Gossypium hirsutum L. roots in the non-saline side under non-uniform root zone salinity. J Exp Bot 67:2247-2261.

Kovács J, Poór P, Szepesi Á and Tari I (2016) Salicylic acid induced cysteine protease activity during programmed cell death in tomato plants. Acta Biol Hung 67:148-58.

Kovács J and van der Hoorn RAL (2016) Twelve ways to confirm targets of activitybased probes in plants. Bioorg Med Chem 24:3304-3311.

Kovács J, Poór P, Kaschani F, Chandrasekar B, Hong T, Misas-Villamil J, Xin BT, Kaiser M, Overkleeft H, Tari I and Van der Hoorn RAL (2017) Proteasome activity profiling uncovers alteration of catalytic $\beta 2$ and $\beta 5$ subunits of the stress-induced proteasome during salinity stress in tomato roots. Front Plant Sci 8:107.

Kunert KJ, van Wyk SG, Cullis CA, Vorster BJ and Foyer CH (2015) Potential use of phytocystatins in crop improvement, with a particular focus on legumes. J Exp Bot 66:35593570.

Kurepa J, Toh-E A and Smalle JA (2008) 26S proteasome regulatory particle mutants have increased oxidative stress tolerance. Plant J 53:102-114.

Kuroyanagi M, Nishimura M and Hara-Nishimura I (2002) Activation of Arabidopsis vacuolar processing enzyme by self-catalytic removal of an auto-inhibitory domain of the Cterminal propeptide. Plant Cell Physiol 43:143-151.

Lampl N, Alkan N, Davydov O and Fluhr R (2013) Set-point control of RD21 protease activity by AtSerpin1 controls cell death in Arabidopsis. Plant J 74:498-510.

Lequeu J, Simon-Plas F, Fromentin J, Etienne P, Petitot AS, Blein JP and Suty L (2005) Proteasome comprising a $\beta 1$ inducible subunit acts as a negative regulator of NADPH oxidase during elicitation of plant defense reactions. FEBS Lett 579:4879-4886.

Leigh RA and Wyn Jones RG (1984) A hypothesis relating critical potassium concentrations for growth to the distribution and functions of this ion in the plant cell. New Phytol 97:1-13.

Lenger J, Kaschani F, Lenz T, Dalhoff C, Villamor JG, Köster H, Sewald N and van der Hoorn RAL (2012) Labeling and enrichment of Arabidopsis thaliana matrix metalloproteases using an active-site directed, marimastat-based photoreactive probe. Bioorgan Med Chem 20:592-596.

Leshem Y, Seri L and Levine A (2007) Induction of phosphatidylinositol 3-kinasemediated endocytosis by salt stress leads to intracellular production of reactive oxygen species and salt tolerance. Plant J 51:185-197. 
Levitt J (1972) Responses of plants to environmental stresses. New York, Academic Press ISBN 0-12-445560-3 p569-665.

Li N, Kuo CL, Paniagua G, van den Elst H, Verdoes M, Willems LI, van der Linden WA, Ruben M, van Genderen E, Gubbens J, van Wezel GP, Overkleeft HS and Florea BI (2013) Relative quantification of proteasome activity by activity-based protein profiling and LCMS/MS. Nat Protoc 8:1155-1168.

Li Y, Kabbage M, Liu W and Dickman MB (2016) Aspartyl protease-mediated cleavage of BAG6 is necessary for autophagy and fungal resistance in plants. Plant Cell 28:233-247.

Lin A, Wang Y, Tang J, Xue P, Li C, Liu L, Hu B, Yang F, Loake GJ and Chu C (2012) Nitric oxide and protein S-nitrosylation are integral to hydrogen peroxide-induced leaf cell death in rice. Plant Physiol 158:451-464.

Lindahl M, Spetea C, Hundal T, Oppenheim AB, Adam Z and Andersson B (2000) The thylakoid FtsH protease plays a role in the light-induced turnover of the photosystem II D1 protein. Plant Cell 12:419-431.

Livak KJ and Schmittgen TD (2001) Analysis of relative gene expression data using real-time quantitative PCR and the 2(-Delta Delta C(T)) Method. Methods 25:402-408.

Liu Y, Dammann C and Bhattacharyya MK (2001) The matrix metalloproteinase gene GmMMP2 is activated in response to pathogenic infections in soybean. Plant Physiol 127:1788-1797.

Liu Y, Wu R, Wan Q, Xie G and Bi Y (2007) Glucose-6-phosphate dehydrogenase plays a pivotal role in nitric oxide-involved defense against oxidative stress under salt stress in red kidney bean roots. Plant Cell Physiol 48:511-522.

Lopez-Molina L, Mongrand S and Chua NH (2001) A postgermination developmental arrest checkpoint is mediated by abscisic acid and requires the $\mathrm{ABI} 5$ transcription factor in Arabidopsis. Proc Natl Acad Sci USA 98:4782-4787.

Löwe J, Stock D, Jap B, Zwickl P, Baumeister W and Hubert R (1995) Crystal structure of the $20 \mathrm{~S}$ proteasome from the archaeon T. acidophilum at $3.4 \mathrm{~A}$ resolution. Science 268:533-539.

Lu S, Su W, Li H and Guo Z (2009) Abscisic acid improves drought tolerance of triploid Bermuda grass and involves $\mathrm{H}_{2} \mathrm{O}_{2}$ - and $\mathrm{NO}$-induced antioxidant enzyme activities. Plant Physiol Biochem 47:132-138.

Lu S, Faris JD, Sherwood R and Edwards MC (2013) Dimerization and protease resistance: new insight into the function of PR-1. J Plant Physiol 170:105-110.

Lu H, Chandrasekar B, Oeljeklaus J, Misas-Villamil JC, Wang Z, Shindo T, Bogyo M, Kaiser M and van der Hoorn RAL (2015) Subfamily-specific fluorescent probes for cysteine proteases display dynamic protease activities during seed germination. Plant Physiol 168:1462-1475. 
Ma NN, Zuo YQ, Liang XQ, Yin B,Wang GD and Meng QW (2013) The multiple stressresponsive transcription factor SINAC1 improves the chilling tolerance of tomato. Physiol Plant doi: 10.1111/ppl.12049.

Maathuis FJM, Ahmad I and Patishtan $\mathrm{J}$ (2014) Regulation of $\mathrm{Na}^{+}$fluxes in plants. Front Plant Sci 5:467.

Maiolica A, Borsotti D and Rappsilber J (2005) Self-made frits for nanoscale columns in proteomics. Proteomics 5:3847-3850.

McGrath KC, Dombrecht B, Manners JM, Schenk PM, Edgar CI, Maclean DJ, Scheible WR, Udvardi MK and Kazan K (2005) Repressor- and activator-type ethylene response factors functioning in jasmonate signaling and disease resistance identified via a genomewide screen of Arabidopsis transcription factor gene expression. Plant Physiol 139:949-959.

Miller G, Suzuki N, Ciftci- Yilmaz S and Mittler R (2010) Reactive oxygen species homeostasis and signalling during drought and salinity stresses. Plant Cell Environ 33:453467.

Misas-Villamil JC, Toenges G, Kolodziejek I, Sadaghiani AM, Kaschani F, Colby T, Bogyo M and Van der Hoorn RAL (2013a) Activity profiling of vacuolar processing enzymes reveals a role for VPE during oomycete infection. Plant $J$ 73:689-700.

Misas-Villamil JC, Kolodziejek I, Crabill E, Kaschani F, Niessen S, Shindo T, Kaiser M, Alfano JR and Van der Hoorn RAL (2013b) Pseudomonas syringae pv. syringae uses proteasome inhibitor syringolin A to colonize from wound infection sites. PLoS Pathog 9:e1003281.

Misas-Villamil JC, Van der Burgh AM, Grosse-Holz F, Pages M, Kovács J, Kaschani F, Schilasky S, Emron Khan Emon A, Ruben M, Kaiser M, Overkleeft HS and Van der Hoorn RAL (2017) Subunit-selective proteasome activity profiling uncovers uncoupled proteasome subunit activities during bacterial infections. Plant J TPJ-00974-2016.

Mittler R, Vanderauwera S, Gollery M and Van Breusegem F (2004) Reactive oxygen gene network of plants. Trends Plant Sci 9:490-498.

Moon J, Parry G and Estelle M (2004) The ubiquitin-proteasome pathway and plant development. Plant Cell 16:3181-3195.

Moreau C, Aksenov N, Lorenzo MG, Segerman B, Funk C, Nilsson P, Jansson S and Tuominen $\mathrm{H}$ (2005) A genomic approach to investigate developmental cell death in woody tissues of Populus trees. Genome Biol 6:R34.

Morgan PG and Drew MC (1997) Ethylene and plant responses to stress. Physiol Plant 100:620-630.

Morimoto $\mathrm{K}$ and Van der Hoorn RAL (2016) The increasing impact of activity-based protein profiling in plant science. Plant Cell Physiol 57:446-461. 
Morris K, MacKerness SA, Page T, John CF, Murphy AM, Carr JP, and BuchananWollaston $V(2000)$ Salicylic acid has a role in regulating gene expression during leaf senescence. Plant J 23:677-685.

Munns R (2002) Comparative physiology of salt and water stress. Plant cell environ 25:239-250.

Munns R and Tester M (2008) Mechanisms of salinity tolerance. Annu Rev Plant Biol 59:651-681.

Murata S, Sasaki K, Kishimoto T, Niwa S, Hayashi H, Takahama Y and Tanaka K (2007) Regulation of CD8+ T cell development by thymus-specific proteasomes. Science 316:1349-1353.

Murata S, Yashiroda H and Tanaka K (2009) Molecular mechanisms of proteasome assembly. Mol Cell Biol 10:104-115.

Neill SJ, Desikan R, Clarke A and Hancock JT (2002) Nitricvoxide is a novel component of abscisic acid signalling in stomatalvguard cells. Plant Physiol 128:13-16.

Niemer M, Mehofer U, Verdianz M, Porodko A, Schähs P, Kracher D, Lenarcic B, Novinec M and Mach L (2015) Nicotiana benthamiana cathepsin B displays distinct enzymatic features which differ from its human relative and aleurain-like protease. Biochimie 30:1-7.

Olsen JV, de Godoy LM, Li G, Macek B, Mortensen P, Pesch R, Makarov A, Lange O, Horning $S$ and Mann M (2005) Parts per million mass accuracy on an Orbitrap mass spectrometer via lock mass injection into a C-trap. Mol Cell Proteomics 4:2010-2021.

Pak J, Liu CY, Huangpu J and Graham JS (1997) Construction and characterization of the soybean leaf metalloproteinase CDNA. FEBS Lett 404:283-288.

Pandey S, Nelson DC and Assmann SM (2009) Two novel GPCR-type G proteins are abscisic acid receptors in Arabidopsis. Cell 136:136-148.

Papadakis AK and Roubelakis-Angelakis KA (2005) Polyamines inhibit NADPH oxidase-mediated superoxide generation and putrescine prevents programmed cell death induced by polyamine oxidase-generated hydrogen peroxide. Planta 220:826-37.

Parent B, Hachez C, Redondo E, Simonneau T, Chaumont F and Tardieu F (2009) Drought and abscisic acid effects on aquaporin content translate into changes in hydraulic conductivity and leaf growth rate: A trans-scale approach. Plant Physiol 149:2000-2012.

Park SY, Fung P, Nishimura N, Jensen DR, Fujii H, Zhao Y, Lumba S, Santiago J, Rodrigues A, Chow TF, Alfred SE, Bonetta D, Finkelstein R, Provart NJ, Desveaux D, Rodriguez PL, McCourt P, Zhu JK, Schroeder Jl, Volkman BF and Cutler SR (2009) Abscisic acid inhibits type $2 \mathrm{C}$ protein phosphatases via the PYR/PYL family of START proteins. Science 324:1068-1071. 
Pena LB, Zawoznik MS, Tomaro ML and Gallego SM (2008) Heavy metals effects on proteolytic system in sunflower leaves. Chemosphere 72:741-746.

Perkins DN, Pappin DJ, Creasy DM and Cottrell JS (1999) Probability-based protein identification by searching sequence databases using mass spectrometry data. Electrophoresis 20:3551-3567.

Pernas M, Sanchez-Monge R and Salcedo G (2000) Biotic and abiotic stress can induce cystatin expression in chestnut. FEBS Lett 467:206-210.

Petkova S, Popova N, Angelova Y, Stefanov B, Iliev L and Popov M (2003) Inhibitory effect of some plant growth regulators and chlorsulfuron on growth, protein composition and proteolytic activity of maize seedlings. Biotechnol Biotechnol Equip 17:77-83.

Petrov VD and Van Breusegem F (2012) Hydrogen peroxide-a central hub for information flow in plant cells. AoB Plants pls014.

Poór P, Gémes K, Horváth F, Szepesi Á, Simon ML and Tari I (2011) Salicylic acid treatment via the rooting medium interferes with the stomatal response, $\mathrm{CO}_{2}$ fixation rate and carbohydrate metabolism in tomato and decreases the harmful effects of subsequent salt stress. Plant Biol 13:105-114.

Poór P, Szopkó D and Tari I (2012) Ionic homeostasis disturbance is involved in tomato cell death induced by $\mathrm{NaCl}$ and salicylic acid. In Vitro Cell Dev Biol Plant 48:377-382.

Poór P, Kovács J, Szopkó D and Tari I (2013) Ethylene signaling in salt stress- and salicylic acid-induced programmed cell death in tomato suspension cells. Protoplasma 250:273-284.

Poór P, Borbély P, Kovács J, Papp A, Szepesi Á, Takács Z and Tari I (2014) Opposite extremes in ethylene/nitric oxide ratio induce cell death in suspension culture and root apices of tomato exposed to salt stress. Acta Biol Hung 65:428-438.

Poór P, Kovács J, Borbély P, Takács Z, Szepesi Á and Tari I (2015) Salt stressinduced production of reactive oxygen- and nitrogen species and cell death in the ethylene receptor mutant Never ripe and wild type tomato roots. Plant Physiol Biochem 97:313-322.

Raghavendra AS, Gonugunta VK, Christmann A and Grill E (2010) ABA perception and signalling. Trends Plant Sci 15:395-401.

Rappsilber J, Mann M and Ishihama Y (2007) Protocol for micro-purification, enrichment, pre-fractionation and storage of peptides for proteomics using StageTips. Nat Protoc 2:1896-1906.

Rejeb IB, Pastor V, Mauch-Mani B (2014) Plant responses to simultaneous biotic and abiotic stress: molecular mechanisms. Plants (Basel) 3:458-75.

Richau KH, Kaschani F, Verdoes M, Pansuriya TC, Niessen S, Stüber K, Colby T, Overkleeft HS, Bogyo M and Van der Hoorn RAL (2012) Subclassification and biochemical 
analysis of plant papain-like cysteine proteases displays subfamily-specific characteristics. Plant Physiol 158:1583-1599.

Rivero RM, Kojima M, Gepstein A, Sakakibara H, Mittler R, Gepstein S and Blumwald E (2007) Delayed leaf senescence induces extreme drought tolerance in a flowering plant. Proc Nat Acad Sci USA 104:19631-19636.

Rosli HG, Zheng Y, Pombo MA, Zhong S, Bombarely A, Fei Z, Collmer A and Martin GB (2013) Transcriptomics-based screen for genes induced by flagellin and repressed by pathogen effectors identifies a cell wall-associated kinase involved in plant immunity. Genome Biol 14:R139.

Rossano R, Larocca M and Riccio P (2011) 2-D zymographic analysis of Broccoli (Brassica oleracea L. var. Italica) florets proteases: follow up of cysteine protease isotypes in the course of post-harvest senescence. J Plant Physiol 168:1517-1525.

Roy M and Wu R (2001) Arginine decarboxylase transgene expression and analysis of environmental stress tolerance in transgenic rice. Plant Sci 160:869-875.

Sairam RK and Tyagi A (2004) Physiology and molecular biology of salinity stress tolerance in plants. Curr Sci India 86:407.

Schiermeyer A, Hartenstein H, Mandal MK, Otte B, Wahner V and Schillberg S (2009) A membrane-bound matrix-metalloproteinase from Nicotiana tabacum cv. BY-2 is induced by bacterial pathogens. BMC Plant Biol 9:83.

Schuber $F(1989)$ Influence of polyamines on membrane functions. Biochem J 260:110.

Schuhmann H and Adamska I (2012) Deg proteases and their role in protein quality control and processing in different subcellular compartments of the plant cell. Physiol Plant 145:224-234.

Scruggs SB, Zong NC, Wang D, Stefani E and Ping P (2012) Post-translational modification of cardiac proteasomes: functional delineation enabled by proteomics. $A m J$ Physiol Heart Circ Physiol 303:H9-H18.

Seifert U, Bialy LP, Ebstein F, Bech-Otschir D, Voigt A, Schröter F, Prozorovski T, Lange N, Steffen J, Rieger M, Kuckelkorn U, Aktas O, Kloetzel PM and Krüger E (2010) Immunoproteasomes preserve protein homeostasis upon interferon-induced oxidative stress. Cell 142:613-624.

Sewelam N, Kazan K and Schenk PM (2016) Global plant stress signaling: reactive oxygen species at the cross-road. Front Plant Sci 7:187.

Shabab M, Shindo T, Gu C, Kaschani F, Pansuriya T, Chintha R, Harzen A, Colby T, Kamoun S and Van der Hoorn RAL (2008) Fungal effector protein AVR2 targets diversifying defense-related cys proteases of tomato. Plant Cell 20:1169-1183. 
Shabala S, Demidchik V, Shabala L, Cuin TA, Smith SJ, Miller AJ, Davies JM and Newman IA (2006) Extracellular $\mathrm{Ca}^{2+}$ ameliorates $\mathrm{NaCl}$-induced $\mathrm{K}^{+}$loss from Arabidopsis root and leaf cells by controlling plasma membrane $\mathrm{K}^{+}$-permeable channels. Plant Physiol 141:1653-1665.

Shabala S (2009) Salinity and programmed cell death: unravelling mechanisms for ion specific signaling. J Exp Bot 60:709-712.

Shabala S (2013) Learning from halophytes: physiological basis and strategies to improve abiotic stress tolerance in crops. Ann Bot 112:1209-1221.

Sharma R., De Vleesschauwer D., Sharma M.K., Ronald P.C. (2013) Recent advances in dissecting stress-regulatory crosstalk in rice. Mol Plant 6:250-260.

Shen YY, Wang XF, Wu FQ, Du SY, Cao Z, Shang Y, Wang XL, Peng CC, Yu XC, Zhu SY, Fan RC, Xu YH and Zhang DP (2006) The Mg-chelatase $\mathrm{H}$ subunit is an abscisic acid receptor. Nature 443:823-826.

Shevchenko A, Tomas H, Havlis J, Olsen JV and Mann M (2006) In-gel digestion for mass spectrometric characterization of proteins and proteomes. Nat Protoc 1:2856-2860.

Shindo T, Misas-Villamil JC, Hörger AC, Song J and Van der Hoorn RAL (2012) A role in immunity for Arabidopsis cysteine protease RD21, the ortholog of the tomato immune protease C14. PLOS ONE 7:e29317.

Shrivastava P and Kumar R (2015) Soil salinity: a serious environmental issue and plant growth promoting bacteria as one of the tools for its alleviation. Saudi J Biol Sci 22:123131.

Silveira JA, Viégas Rde A, da Rocha IM, Moreira AC, Moreira Rde A, Oliveira JT (2003) Proline accumulation and glutamine synthetase activity are increased by salt-induced proteolysis in cashew leaves. J Plant Physiol 160:115-123.

Simões I and Faro C (2004) Structure and function of plant aspartic proteinases. Eur $J$ Biochem 271:2067-2075.

Singh J, Sastry EVD and Singh V (2012) Effect of salinity on tomato (Lycopersicon esculentum Mill.) during seed germination stage. Physiol Mol Biol Plants 18:45-50.

Song J, Win J, Tian M, Schornack S, Kaschani F, llyas M, Van der Hoorn RAL and Kamoun S (2009) Apoplastic effectors secreted by two unrelated eukaryotic plant pathogens target the tomato defense protease Rcr3. Proc Natl Acad Sci USA 106:1654-1659.

Soon FF, Ng LM, Zhou XE, West GM, Kovach A, Tan MH, Suino-Powell KM, He Y, Xu Y, Chalmers MJ, Brunzelle JS, Zhang H, Yang H, Jiang H, Li J, Yong EL, Cutler S, Zhu JK, Griffin PR, Melcher K and Xu HE (2012) Molecular mimicry regulates ABA signaling by SnRK2 kinases and PP2C phosphatases. Science 335:85-88.

Steffens B and Sauter M (2005) Epidermal cell death in rice (Oryza sativa L.) is regulated by ethylene, gibberellin and abscisic acid. Plant Physiol 139:713-721. 
Stone SL (2014) The role of ubiquitin and the 26S proteasome in plant abiotic stress signaling. Front Plant Sci 5:135.

Sueldo D, Ahmed A, Misas-Villamil J, Colby T, Tameling W, Joosten MH and Van der Hoorn RAL (2014) Dynamic hydrolase activities precede hypersensitive tissue collapse in tomato seedlings. New Phytol 203:913-925.

Suty L, Lequeu J, Lancon A, Etienne P, Petitot AS and Blein JP (2003) Preferential induction of 20S proteasome subunits during elicitation of plant defense reactions: towards the characterization of "plant defense proteasomes". Int J Biochem Cell Biol 35:637-650.

Szepesi Á, Csiszár J, Gémes K, Horváth E, Horváth F, Simon ML and Tari I (2009) Salicylic acid improves acclimation to salt stress by stimulating abscisic aldehyde oxidase activity and abscisic acid accumulation, and increases $\mathrm{Na}^{+}$content in leaves without toxicity symptoms in Solanum lycopersicum L. J Plant Physiol 166:914-925.

Tanaka K and Kasahara M (1998) The MHC class I ligand-generating system: roles of immunoproteasomes and the interferon-Y-inducible proteasome activator PA28. Immunol Rev 163:161-176.

Tanaka H, Onouchi H, Kondo M, Hara-Nishimura I, Nishimura M, Machida C and Machida $Y$ (2001) A subtilisin-like serine protease is required for epidermal surface formation in Arabidopsis embryos and juvenile plants. Development 128:4681-4689.

Tang W and Newton RJ (2005) Polyamines reduce salt-induced damage by increasing the activities of antioxidant enzymes and decreasing lipid peroxidation in Virginia pine. Plant Growth Regul 46:31-43.

Tao JJ, Chen HW, Ma B, Zhang WK, Chen SY, and Zhang JS (2015) The role of ethylene in plants under salinity stress. Front Plant Sci 6:1059.

Tawa P, Hell K, Giroux A, Grimm E, Han Y, Nicholson DW and Xanthoudakis S (2004) Catalytic activity of caspase- 3 is required for its degradation: stabilization of the active complex by synthetic inhibitors. Cell Death Differ 11:439-447.

Than ME, Helm M, Simpson DJ, Lottspeich F Huber R and Gietl C (2004) The 2.0 A crystal structure and substrate specificity of the KDEL-tailed cysteine endopeptidase functioning in programmed cell death of Ricinus communis endosperm. J Mol Biol 336:11031116.

Tian M, Win J, Van der Hoorn RAL, Van der Knaap E and Kamoun S (2007) A Phytophthora infestans cystatin-like protein targets a novel tomato papain-like apoplastic protease. Plant Physiol 143:364-377.

Tornero P, Mayda E, Gómez MD, Canas L, Conejero V and Vera P (1996) Characterization of LRP, a leucine-rich repeat (LRR) protein from tomato plants that is processed during pathogenesis. Plant $J$ 10:315-330. 
Trobacher CP, Senatore A and Greenwood JS (2006) Masterminds or minions? Cysteine proteinases in plant programmed cell death. Can J Bot 84:651-667.

Trobacher CP, Senatore A, Holley C and Greenwood JS (2013) Induction of a ricinosomal-protease and programmed cell death in tomato endosperm by gibberellic acid. Planta 237:665-679.

Turk B, Turk V and Turk D (1997) Structural and functional aspects of papain-like cysteine proteinases and their protein inhibitors. Biol Chem 378:141-150.

Turk V, Turk B and Turk D (2001) Lysosomal cysteine proteases: facts and opportunities. EMBO J 20:4629-4633.

Turk V, Stoka V, Vasiljeva O, Renko M, Sun T, Turk B and Turk D (2012) Cysteine cathepsins: from structure, function and regulation to new frontiers. Biochim Biophys Acta 1824:68-88.

Umeda M, Manabe $Y$ and Uchimiya H (1997) Phosphorylation of the C2 subunit of the proteasome in rice (Oryza sativa L.). FEBS Lett 403:313-317.

Umezawa T, Sugiyama N, Mizoguchi M, Hayashi S, Myouga F, Yamaguchi-Shinozaki K, Ishihama Y, Hirayama T and Shinozaki K (2009) Type 2C protein phosphatases directly regulate abscisic acid-activated protein kinases in Arabidopsis. Proc Natl Acad Sci USA 106:17588-17593.

Vandelle E and Delledonne M (2011) Peroxynitrite formation and function in plants. Plant Sci 181:534-9.

Van der Hoorn RAL, Leeuwenburgh MA, Bogyo M, Joosten MH and Peck SC (2004) Activity profiling of papain-like cysteine proteases in plants. Plant Physiol 135:1170-1178.

Van der Hoorn RAL (2008) Plant proteases: from phenotypes to molecular mechanisms. Annu Rev Plant Biol 59:191-223.

Van der Linde K, Mueller AN, Hemetsberger C, Kashani F, Van der Hoorn RAL and Doehlemann G (2012) The maize cystatin CC9 interacts with apoplastic cysteine proteases. Plant Signal Behav 7:1397-1401.

Van Wyk SG, Du Plessis M, Cullis CA, Kunert KJ and Vorster BJ (2014) Cysteine protease and cystatin expression andactivity during soybean nodule developmentand senescence. BMC Plant Biol 14:294.

Vaseva I, Sabotič J, Šuštar-Vozlič J, Meglič V, Kidrič M, Demirevska K and SimovaStoilova L (2012) The response of plants to drought stress: the role of dehydrins, chaperones, proteases and protease inhibitors in maintaining cellular protein function. Nova Science Publishers ISBN:978-1-62100-769-2.

Velarde-Buendía AM, Shabala S, Cvikrova M, Dobrovinskaya O and Pottosin I (2012) Salt-sensitive and salt-tolerant barley varieties differ in the extent of potentiation of the ROSinduced $\mathrm{K}^{+}$efflux by polyamines. Plant Physiol and Bioch 61:18-23. 
Ventadour S, Jarzaguet M, Wing SS, Chambon C, Combaret L, Béchet D, Attaix D and Taillandier D (2007) A new method of purification of proteasome substrates reveals polyubiquitination of $20 \mathrm{~S}$ proteasome subunits. J Biol Chem 282:5302-5309.

Verdoes M, Willems LI, van der Linden WA, Duivenvoorden BA, van der Marel GA, Florea BI, Kisselev AF and Overkleeft HS (2010) A panel of subunit-selective activity-based proteasome probes. Org Biomol Chem 8:2719-2727.

Verma V, Ravindran P and Kumar PP (2016) Plant hormone-mediated regulation of stress responses. BMC Plant Biol 16:86.

Vierstra RD (2003) The ubiquitin/26S proteasome pathway, the complex last chapter in the life of many plant proteins. Trends Plant Sci 8:135-142.

Volkov V (2015) Salinity tolerance in plants. Quantitative approach to ion transport starting from halophytes and stepping to genetic and protein engineering for manipulating ion fluxes. Front Plant Sci 6:873.

Wagstaff C, Leverentz MK, Griffiths G, Thomas B, Chanasut U, Stead AD and Rogers HJ (2002) Cysteine protease gene expression and proteolytic activity during senescence of Alstroemeria petals. J Exp Bot 53:233-240.

Wang S, Kurepa J and Smalle JA (2009) The Arabidopsis 26 S proteasome subunit RPN1a is required for optimal plant growth and stress responses. Plant Cell Physiol 50:17211725.

Wang R, Liu S, Wang J, Dong Q, Xu L and Rui Q (2013) Purification, characterization and identification of a senescence related serine protease in dark-induced senescent wheat leaves. Phytochem 95:118-126.

Weerapana E, Wang C, Simon GM, Richter F, Khare S, Dillon MBD, Bachovchin DA, Mowen K, Baker D and Cravatt BF (2010) Quantitative reactivity profiling predicts functional cysteines in proteomes. Nature 468:790-795.

Whitlow TH, Bassuk NL, Ranney TG and Reichert DL (1992) An improved method for using electrolyte leakage to assess membrane competence in plant tissues. Plant Physiol 98:198-205.

Wilkinson KD (2000) Ubiquitination and deubiquitination: targeting of proteins for degradation by the proteasome. Semin Cell Dev Biol 11:141-148.

Wright AT and Cravatt BF (2007) Chemical proteomic probes for profiling cytochrome p450 activities and drug interactions in vivo. Chem Biol 14:1043-1051.

Wu A, Allu AD, Garapati P, Siddiqui H, Dortay H, Zanor MI, Asensi-Fabado MA, Munné-Bosch S, Antonio C, Tohge T, Fernie AR, Kaufmann K, Xue GP, Mueller-Roeber B and Balazadeha S (2012) JUNGBRUNNEN1, are active oxygen species-responsive NAC transcription factor, regulates longevity in Arabidopsis. Plant Cell 24:482-506. 
Wu SJ, Ding L and Zhu JK (1996) SOS1, a genetic locus essential for salt tolerance and potassium acquisition. Plant Cell 8:617-627.

Yamada K, Nishimura M and Hara-Nishimura I (2004) The slow wound-response of YVPE is regulated by endogenous salicylic acid in Arabidopsis. Planta 218:599-605.

Yamada K, Shimada T, Nishimura M, Hara-Nishimura I (2005) A VPE family supporting various vacuolar functions in plants. Physiol Plant 123:369-375.

Yao X, Xiong W, Ye T and Wu Y (2012) Overexpression of the aspartic protease ASPG1 gene confers drought avoidance in Arabidopsis. J Exp Bot 63:2579-93.

Ye N,Zhu G,Liu Y,Li Y and Zhang J (2011) ABA controls $\mathrm{H}_{2} \mathrm{O}_{2}$ accumulation through the induction of OsCATB in rice leaves under water stress. Plant Cell Physiol 52:689-698.

Yee D and Goring DR (2009) The diversity of plant U-box E3 ubiquitin ligases: from upstream activators to downstream target substrates. J Exp Bot 60:1109-1121.

Yoshida R, Umezawa T, Mizoguchi T, Takahashi S, Takahashi F and Shinozaki K (2006) The regulatory domain of SRK2E/OST1/SnRK2.6 interacts with ABI1 and integrates abscisic acid (ABA) and osmotic stress signals controlling stomatal closure in Arabidopsis. $J$ Biol Chem 281:5310-5318.

Yoshimura K, Masuda A, Kuwano M, Yokota A and Akashi K (2008) Programmed proteome response for drought avoidance/tolerance in the root of a C3 xerophyte (wild watermelon) under water deficits. Plant Cell Physiol 49:226-241.

Yu M, Lamattina L, Spoel SH and Loake GJ (2014) Nitric oxide function in plant biology: a redox cue in deconvolution. New Phytol 202:1142-1156.

Zepeda-Jazo I, Shabala S, Chen Z and Pottosin II (2008) Na-K transport in roots under salt stress. Plant Signal Behav 3:401-403.

Zepeda-Jazo I, Velarde-Buendía AM, Enríquez-Figueroa R, Bose J, Shabala S, MuñizMurguía J and Pottosin II (2011) Polyamines interact with hydroxyl radicals in activating $\mathrm{Ca} 2+$ and $\mathrm{K}+$ transport across the root epidermal plasma membranes. Plant Physiol 157:2167-2180.

Zhang HX and Blumwald E (2001) Transgenic salt-tolerant tomato plants accumulate salt in foliage but not in fruit. Nat Biotechnol 19:765-768.

Zhang F, Su K, Yang X, Bowe DB, Paterson AJ and Kudlow JE (2003) O-GlcNAc modification is an endogenous inhibitor of the proteasome. Cell 115:715-725.

Zhang $\mathrm{H}$, Huang Z, Xie B, Chen Q, Tian X, Zhang X, Zhang H, Lu X, Huang D and Huang R (2004) The ethylene-, jasmonate-, abscisic acid- and $\mathrm{NaCl}$-responsive tomato transcription factor JERF1 modulates expression of GCC box-containing genes and salt tolerance in tobacco. Planta 220:262-70. 
Zhang Y, Wang L, Liu Y, Zhang Q, Wei Q and Zhang W (2006) Nitric oxide enhances salt tolerance in maize seedlings through increasing activities of proton-pump and $\mathrm{Na}^{+} / \mathrm{H}^{+}$ antiport in the tonoplast. Planta 224:545-55.

Zhang A, Jiang M, Zhang J, Ding H, Xu S, Hu X and Tan M (2007) Nitric oxide induced by hydrogen peroxide mediates abscisic acid-induced activation of the mitogen-activated protein kinase cascade involved in antioxidant defense in maize leaves. New Phytol 175:3650.

Zhang Y, Tan J, Guo Z, Lu S, He S, Shu W and Zhou B (2009) Increased abscisic acid levels in transgenic tobacco over-expressing 9 cis-epoxycarotenoid dioxygenase influence $\mathrm{H}_{2} \mathrm{O}_{2}$ and $\mathrm{NO}$ production and antioxidant defences. Plant Cell Environ 32:509-519.

Zhang H, Ni L, Liu Y, Wang Y, Zhang A, Tan M and Jiang M (2012) The C2H2-type zinc finger protein ZFP182 is involved in abscisic acid-induced antioxidant defense in rice. $J$ Integr Plant Biol 54:500-510.

Zhang XL, Jiang L, Xin Q, Liu Y, Tan JX and Chen ZZ (2015) Structural basis and functions of abscisic acid receptors PYLs. Front Plant Sci 6:88.

Zheng J, Dasgupta A and Bizzozero OA (2012) Changes in 20 S subunit composition are largely responsible for altered proteasomal activities in experimental autoimmune encephalomyelitis. J Neurochem 121:486-494.

Zhu JK (2002) Salt and drought stress signal transduction in plants. Annu Rev Plant Biol 53:247-273.

Zong C, Young GW, Wang Y, Lu H, Deng N, Drews O and Ping P (2008) Twodimensional electrophoresis-based characterization of post-translational modifications of mammalian $20 \mathrm{~S}$ proteasome complexes. Proteomics 8:5025-5037. 


\section{Supplementary data}

$\begin{array}{llll}\text { Probe } & \text { Specificity } & \text { Warhead } & \text { Tag } \\ \text { MV201 } & \text { PLCPs, proteasome catalytic subunits } & \text { epoxide } & \text { Bodipy- } \\ & (\beta 1, \beta 2, \beta 5) & \text { N3 } \\ \text { DCG04 } & \text { PLCPs } & \text { epoxide } & \text { Biotin } \\ \text { JOPD1 } & \text { VPE } & \text { AOMK } & \text { Bodipy } \\ \text { MVB072 } & \text { proteasome catalytic subunits }(\beta 1, \beta 2, & \text { Epoxyketone } & \text { Bodipy- } \\ & \beta 5) & \text { Biotin } \\ \text { LW124 } & \text { proteasome catalytic subunit }(\beta 1) & \text { Epoxyketone } & \text { Bodipy } \\ \text { MVB127 } & \text { proteasome catalytic subunit }(\beta 5) & \text { Vinyl sulphone } & \text { Bodipy } \\ \text { FY01 } & \text { aleurain-like proteases } & \text { Vinyl sulphone } & \text { Bodipy }\end{array}$

Table S1 Features of ABPs were used in this study. Listed by names, specificity, warhead and tag. 
A

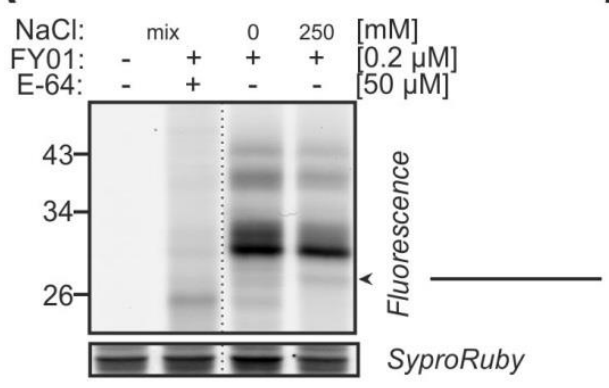

B

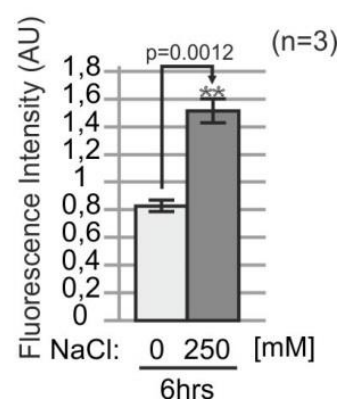

Figure S1 Profiling of aleurain-like proteases upon 0- and $250 \mathrm{mM} \mathrm{NaCl}$ treatment at $6 \mathrm{~h}$ with FY01. The quantified $28 \mathrm{kDa}$ signal is plotted on the right. Error bars indicate SEM of $\mathrm{n}=3$ samples. 


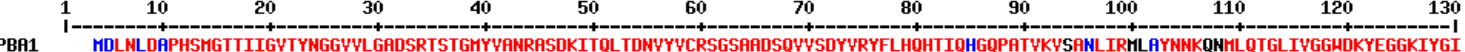

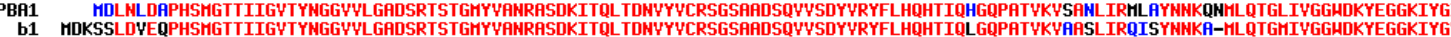
:nsus ...ndL\#1\#APHSHGTIIIGYTYNGGYYGGDSRTSTGHYYANRASDKITQLTDNYYYCRSGSARDSQYYSDYYRYFLHQHTIQhGQPATYKYaARLIRqiaYNNKa. HLQTG\$IYGGHDKYEGGKIYG

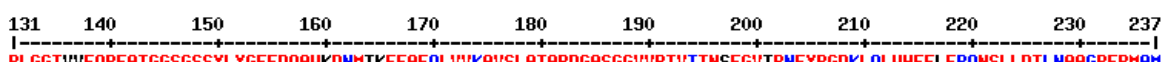

PBA1 PLGGTYYEQPFAIGGSGSSYLYGFFDQALKDNHTKEEAEQL YYKAYSLATARDGASGGYVTYYITNSEGYTRNFYPGDKLQLLHEELEPQNSLLDTLNAFGPEPMAM

insus PLGGTIIEQPFAIGGSGSSYLYGFFDQRHr \#nI'shEEAEqLYYkAYSLAIARDGASGGYYRT ! iINk\#GYkRnFYPGDkLqLHHEEiEPqNSLLDIInAfgP\#PHan

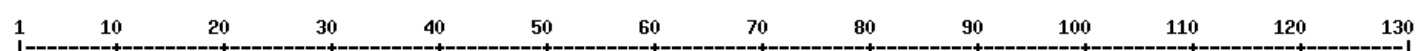

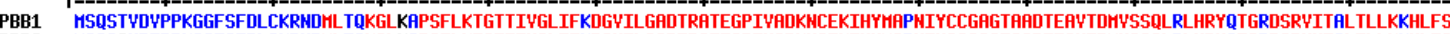

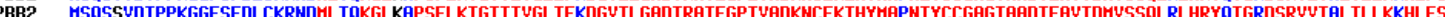
KGLRSPSFLKTGTTIYGLIFQDGYILGADTRATEGPIYADKNCEKIHYHFHNIYCCGAGTAADTEAYTDHYSSQLKLHRYHTGHESRYYTALTLLKSHLFSY
150
160
170
180
190
200
210
220
230
240
$250 \quad 260$

PBB1 QGHYSAFL YLGGYDITGPHLHTIYPHGSTDTLPFATMGSGSLARIISYFEAKYKEGLTRDEGIKLYHESICSGIFNDLGSGSNYDICYITKGNKEYLRNYMEPNPRTYYSSKGYSFTKKTEYLLTKITPL

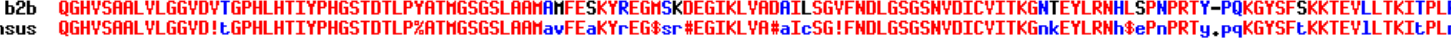

$261 \quad 270 \quad 275$

PBB1 ERYEITEY-GEAMEE

PBB2 ERYETYEYAGEAMEE

b2a ENYEYIEG-GDAME

nsus Er $\psi \#$ ! iEg.G\#AMIEE
10
$20 \quad 30$
3040
50
60
$70 \quad 80$
90
100
110
130

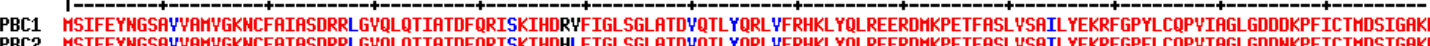

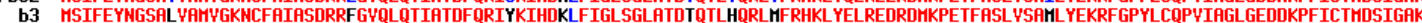

nsus MSIFEYHGSAvYAMYGKNCFAIASDRRIGYQLQTIATDFQRIsKIHD. IFIGLSGLATDvQTLYQRLVFRHKLY \#LRE\#RDHKPETFASLYSAILYEKRFGP\%LCQPYIAGLG\#D\#KPFICTMDSIGAKE
150
160
180
190
200204

PBC1 LAKDFYYSGTASESLYGACEAHYKPDHEREELFETISQRLLSSYDRDCLSGHGGHYYYYTPTEIKERTLKGRHI

PBC2 LAKDFYWSGTASESLYGACEAMFKPDHEAEELFETISQALLSSYDRDCLSGHGGHYYYYTPKEYKERILKGRT

nsus LAKDFYYSGTASESLYGACEAH\%KPDHeaEELFETISQRLLSSYDRDCLSGHGGHYY!YTPEE! KERILKGRHID

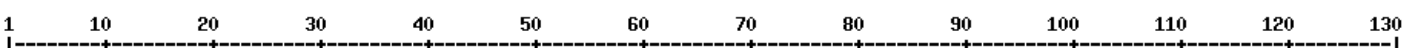

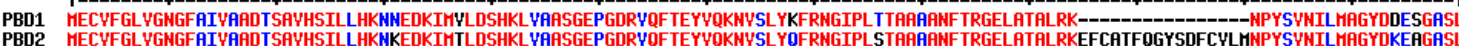

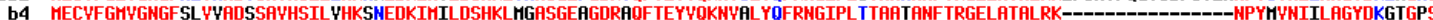

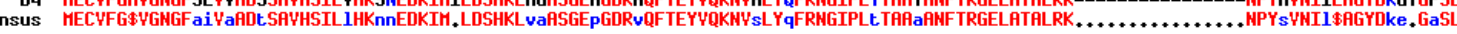

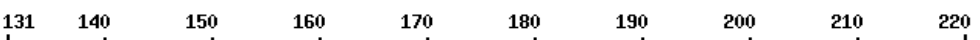

PBD1 YYIDYIATLHKYDKGAFGYGSYFSLSTMDRHYRSDHSYEEAIELYVKCTLEIRSRLYYPPPNFYIKIYDKDGRRDYRLRQSYKDYTTAYY

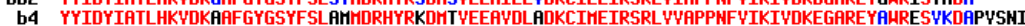

nsus YYIDYIATLHKYDKgAFGYGSYFSLstMDRHYRsDHsYEEA! \#LuDKCISEIRSRLY! APPNFYIKIYDK\#GAR\#YaHR, SukDa....

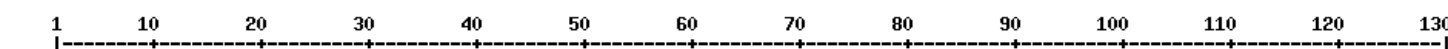

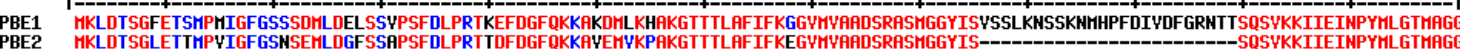

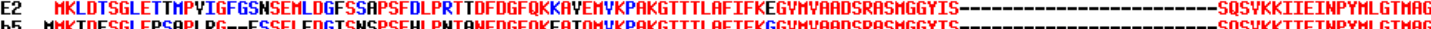

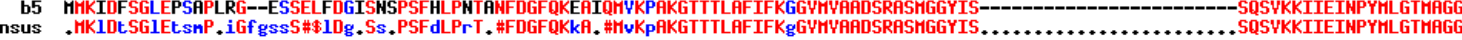
150
160
170
190
200
210
220
230
240
$250 \quad 260$

PBE1 ARDCQFUHRNLGIKCRLHELANKRRISYSGASKLLANMLYSYRGMGLSWGTMIAGHDETGPGLYYYDNEGGRLKGDRFSWGSGSPYAYGYLDSGYKYDMSYEEASELARRSTYHATFRDGASGGYASYYH PBE2 AADCQFHHRNLGIKCRLHELANKRRISYSGASKLLANILYSYRGMGLSYGTMIAGHDETGPGLYYYDNEGGRLKGDRFSYGSGSPYAYGYLDSGYKFDDSYEEASELARRSTYHATFRDGASGGYASYYH

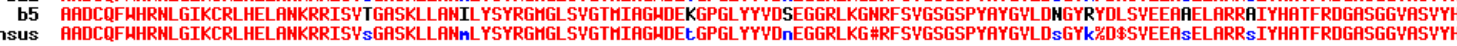
$261 \quad 270 \quad 280 \quad 290 \quad 299$

PBE1 VGPEGHTKLSGDDUGELHYHYYPYAPATHEQVMEEATAE

PBE2 YGPQGHTKLSGDDYGELHYHYYPYAPITAEHYMEEARE

b5 YGPHGHKKLSGDDYGELHYHYYPYEYARYEQEMREYPYA

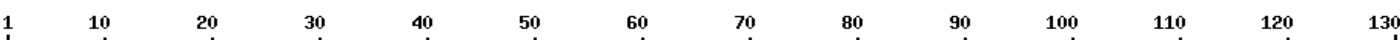

PBF1 MTKQHANHSPYDNHGGTCYAIAGSDYCYIAADTRMSTGYSTLSRDYSKIHKLADRAYLSSSGFQADVKALQKYLKSRHLIYQHQHNKQMSCPAMAQLLSNTLYFKRFFPYYAFNYLGGLDEEGKGCYFTYY

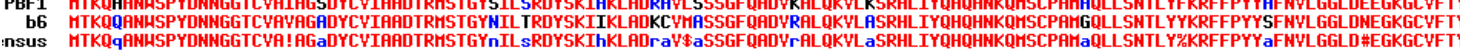
$131 \quad 140$
$150 \quad 160$
$170 \quad 180$
190
$210-220223$

PBF1 DAYGSYERYGYGAOGSGSTLIMPFLDNOLKSPSPLLLPKODSNTPLSEAEAYDLYKTYFASATERDTYTGDKLETMTLKADGIKTELMDLRKD

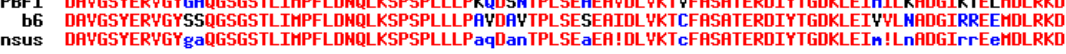

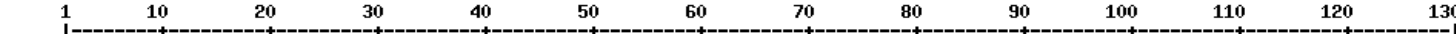

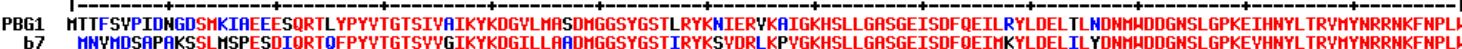

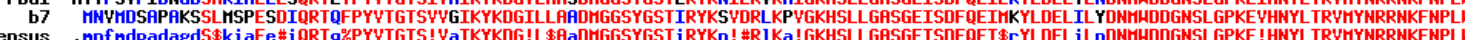
$190 \quad 200$
210
220
$230 \quad 240 \quad 246$

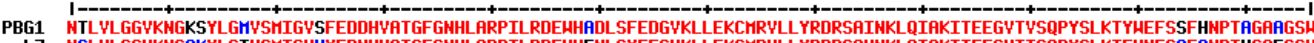

b7 NSLYLGGYKNGQKYLGTYSHIGYHYEDNHYATGFGNHLARPILRDEHHENLSYEEGYKLLEKCMRYLLYRDRSAYHKLQTAKITEEGYTISQPYSLKTFLNFSAFQNPTYGFEGSH

Figure S2 Alignment of Arabidopsis and tomato $\beta$ subunit protein sequences per subfamily. 
Experiment 2

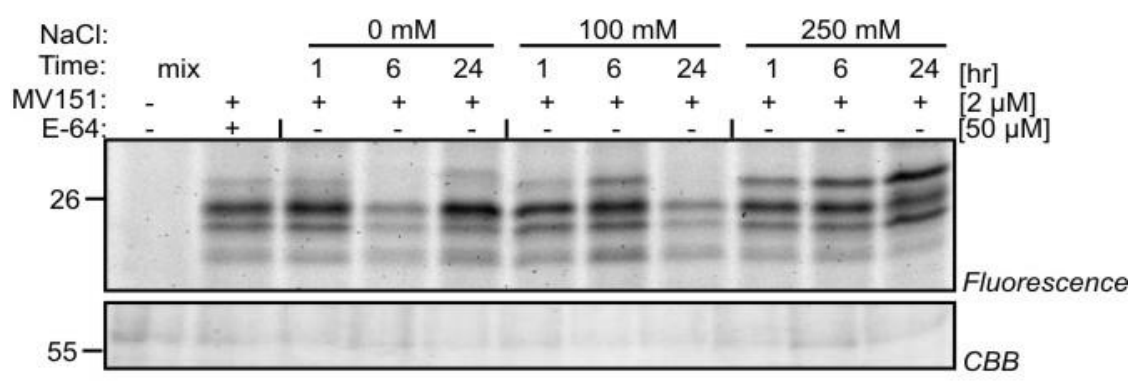

Experiment 3

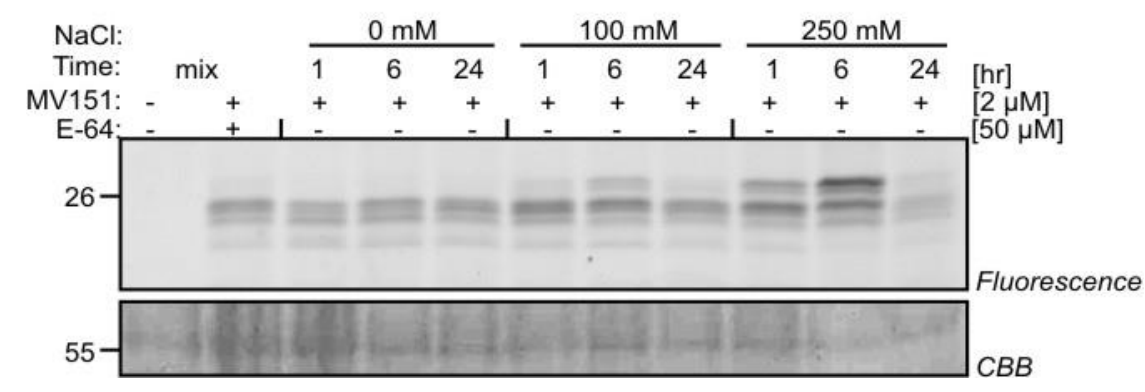

Figure S3 Two additional experimental replicates of MV151 labeling. Tomato roots were treated with 0-, 100- and $250 \mathrm{mM} \mathrm{NaCl}$ and root extracts were generated after 1, 6 and 24 hours and labeled with $2 \mu \mathrm{M}$ MV151. A mix of all nine samples was pre-incubated with or without $50 \mu \mathrm{M}$ E-64 and labeled with $2 \mu \mathrm{M}$ MV151. 

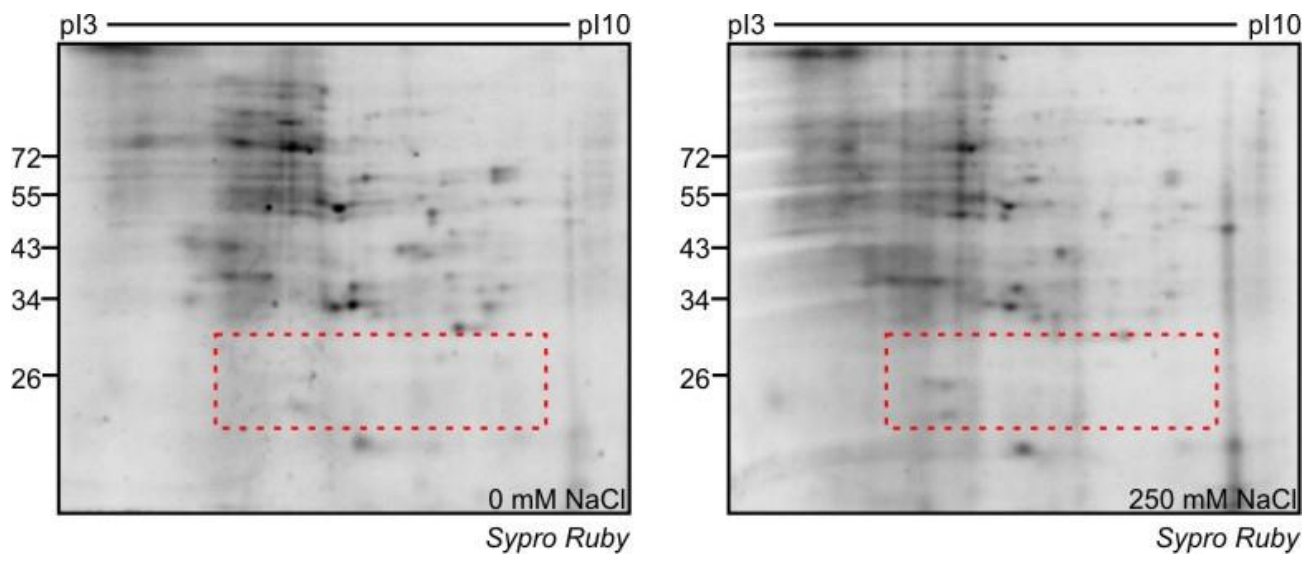

Figure S4 Sypro Ruby-stained 2D gels, shown in Figure 5A. The regions that are shown in Figure $5 \mathrm{~A}$ are highlighted with the red box. 

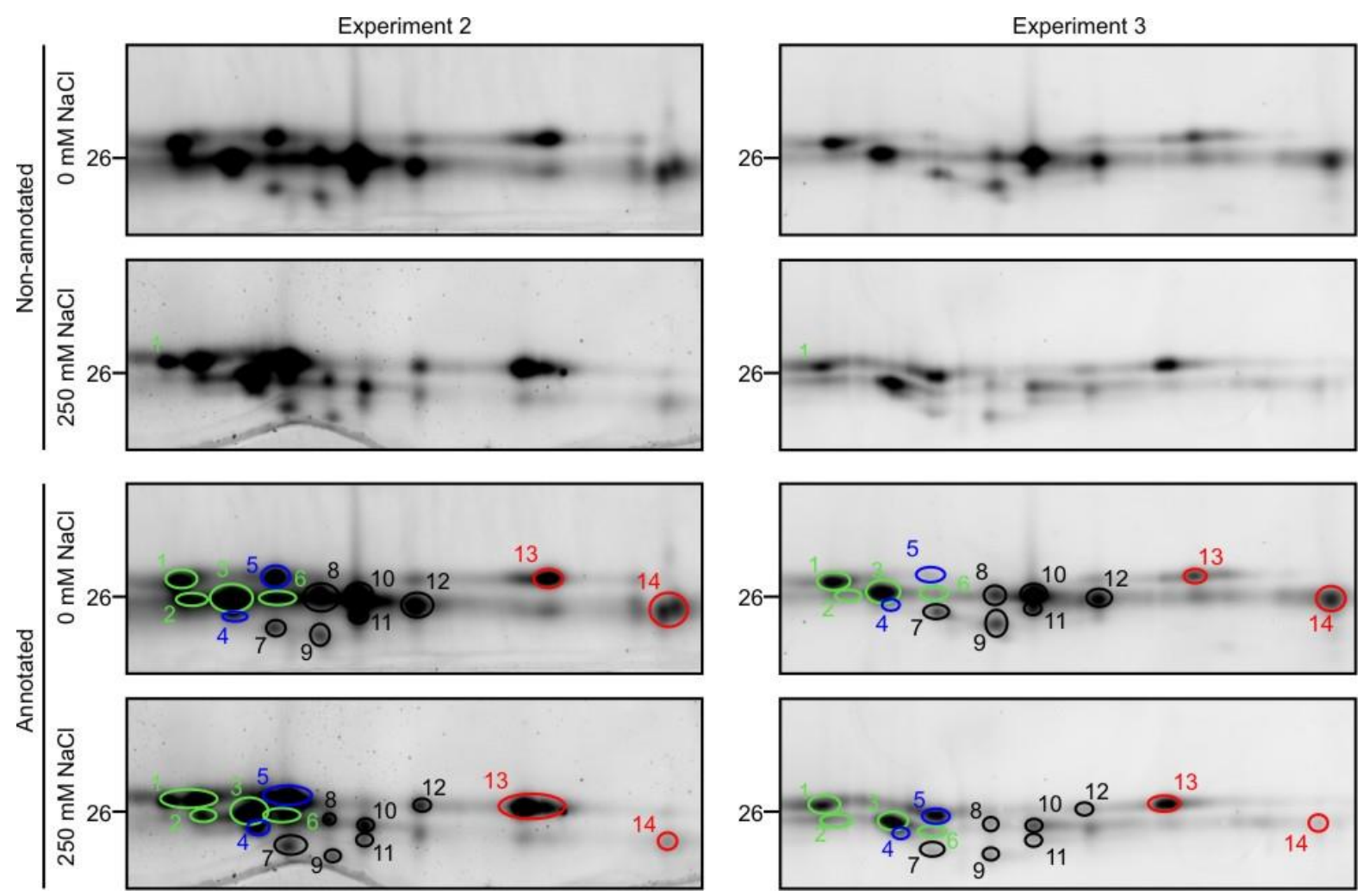

Figure S5 Two additional biological replicates of fluorescent 2D gels. Tomato roots were treated with 0 - and $250 \mathrm{mM} \mathrm{NaCl}$ and root extracts were generated after 6 hours and labeled with $0.2 \mu \mathrm{M}$ MVB072. Samples were separated on IEF 2D gel. Spots are highlighted with different colors: $\beta 1$ (green); $\beta 2$ (blue); and $\beta 5$ (red). 
>Solyc07g016200.2.1 $\beta 1$

MDKSSLDVEQPHSMGTI I GVTYNGGVVLGADSRTSTGMYVANRASDKITQLTDNVYVCRSGSA ADSQVVSDYVRYFLHQHTIQLGQPATVKVAASLIRQISYNNKAMLQTGMIVGGWDKYEGGKIYGVPLG GTLLEQPFAIGGSGSSYLYGFFDQAWREGMSHEEAEKLVVTAVSLAIARDGASGGVVRTITINKDGVK RKFYPGDTLPLWHEEIESVNSLLDIVPAASPDPMVS

>Solyc04g024420.2.1 $\beta 2 a$

MASNATIDVPSKGGFSFDLCRRNEMLLKKGLRSPSFLKTGTTIVGLIFQDGVILGADTRATEGP IVADKNCEKIHYMAHNIYCCGAGTAADTEAVTDMVSSQLKLHRYHTGHESRVVTALTLLKSHLFSYQG HVSAALVLGGVDVSGPHLHTIYPHGSTDTLPYATMGSGSLAAMA I FESKYREGLSKNEGIKLVAEAIL SGVFNDLGSGSNVDICVITKGHTEYLRNHMS PYPRTDPQKGYSFPKKTEVILTKI I PLREMVEVIEGG DAMEE

>Solyc05g013820.2.1 $\beta 2 b$

MLVSKGLRSPSELKTG TIVGLIFKDGVILGADTRATEGPIVADKNCEKIHYMAPNIYCCGAGT AADTEAVTDMVSSQLKLHRYHTGRESRVVTSLTLLKSHLFSYQGHVSAALVLGGVDVTGPHLHTIYPH GSTDTLPYATMGSGSLAAMAMFESKYREGMSKDEGIKLVADAILSGVFNDLGSGSNVDICVITKGNTE YLRNHLSPNPRTYPQKGYSFSKKTEVLLTKITPLREIVQVIEGGDAMEE

>Solyc05g056160.2.1 ß5

MMKIDFSGLEPSAPLRGESSELFDGISNSPSFHLPNTANFDGFQKEAIQMVKPAKG

TTLAFIF KGVMVAADSRASMGGYISSQSVKKI IE INPYMLGTMAGGAADCQFWHRNLGIKCRLHELANKRRISV TGASKLLANILYSYRGMGLSVGTMIAGWDEKGPGLYYVDSEGGRLKGNRFSVGSGSPYAYGVLDNGYR YDLSVEEAAELARRA IYHATFRDGASGGVASVYHVGPNGWKKLSGDDVGELHYHYYPVEVAAVEQEMA EVPVA

unique and ambiguous peptides

Figure S6 Position of identified peptides on proteasome sequences. Unique peptides are highlighted in red, ambiguous peptides are highlighted in yellow, peptides that overlap with a larger peptide are underlined. Catalytic Thr is highlighted in blue. The prodomain is printed in grey. 

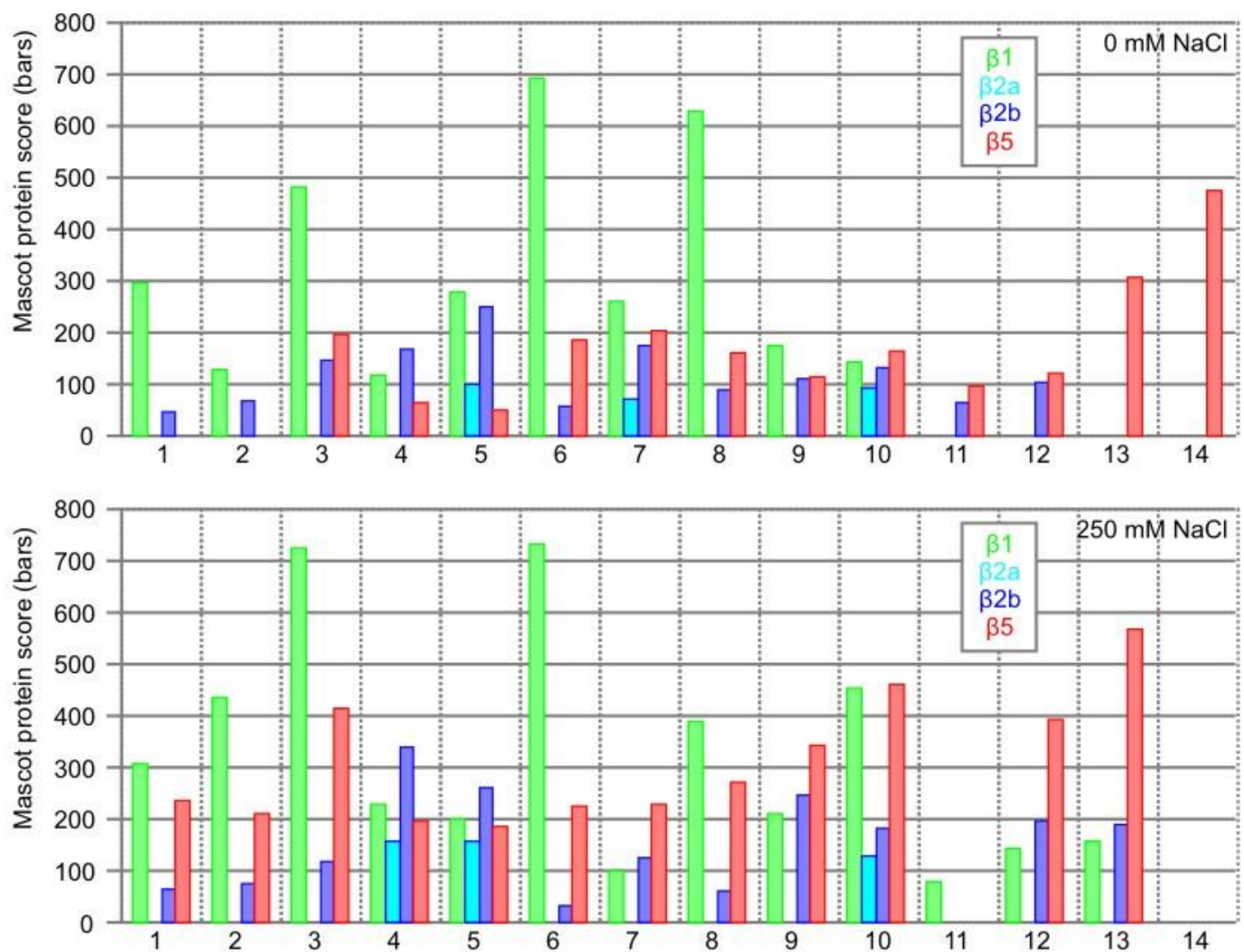

Assignment:

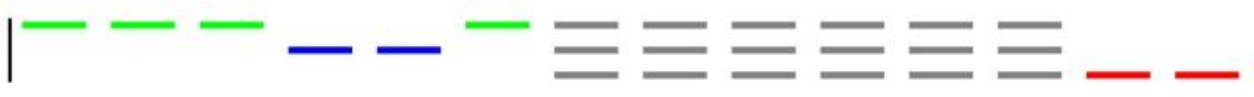

Figure S7 Mascot scores of identified proteasome catalytic subunits after separation with IEF 2D PAGE. Mascot scores are show for each of the four detected catalytic subunits. The assigned subunit composition is shown on the bottom. 
Table S2 Identified peptides of catalytic subunits.

\begin{tabular}{|c|c|c|c|c|}
\hline Peptide sequence & $\mathbf{u} / \mathbf{a}$ & PSM & Subunit & Accesion \\
\hline ITQLTDNVYVCR & u & 29 & $\beta 1$ & Solyc07g016200.2.1 \\
\hline LVVTAVSLAIAR & $\mathrm{u}$ & 32 & $\beta 1$ & Solyc07g016200.2.1 \\
\hline AM* LQTGM* IVGGWDK & u & 8 & $\beta 1$ & Solyc07g016200.2.1 \\
\hline DGASGGVVR & u & 19 & $\beta 1$ & Solyc07g016200.2.1 \\
\hline VAASLIR & $\mathrm{u}$ & 21 & $\beta 1$ & Solyc07g016200.2.1 \\
\hline TSTGM* YVANR & u & 18 & $\beta 1$ & Solyc07g016200.2.1 \\
\hline EGMSHEEAEK & u & 5 & $\beta 1$ & Solyc07g016200.2.1 \\
\hline SGSAADSQVVSDYVR & u & 20 & $\beta 1$ & Solyc07g016200.2.1 \\
\hline ASDKITQLTDNVYVCR & $\mathrm{u}$ & 12 & $\beta 1$ & Solyc07g016200.2.1 \\
\hline $\mathrm{AM} * \mathrm{LQTGM} *$ IVGGWDKYEGGK & u & 17 & $\beta 1$ & Solyc07g016200.2.1 \\
\hline TITINKDGVK & $\mathrm{u}$ & 7 & $\beta 1$ & Solyc07g016200.2.1 \\
\hline YFLHQHTIQLGQPATVK & u & 9 & $\beta 1$ & Solyc07g016200.2.1 \\
\hline TSTGMYVANR & u & 2 & $\beta 1$ & Solyc07g016200.2.1 \\
\hline$A M * L Q T G M I V G G W D K$ & u & 3 & $\beta 1$ & Solyc07g016200.2.1 \\
\hline AMLQTGMIVGGWDK & u & 1 & $\beta 1$ & Solyc07g016200.2.1 \\
\hline QISYNNK & u & 1 & $\beta 1$ & Solyc07g016200.2.1 \\
\hline ATEGPIVADK & a & 16 & $\beta 2 a$ & Solyc04g024420.2.1 \\
\hline ATEGPIVADKNCEK & a & 6 & $\beta 2 a$ & Solyc04g024420.2.1 \\
\hline TEVILTK & a & 5 & $\beta 2 a$ & Solyc04g024420.2.1 \\
\hline KTEVILTK & a & 10 & $\beta 2 a$ & Solyc04g024420.2.1 \\
\hline VVTALTLLK & u & 4 & $\beta 2 a$ & Solyc04g024420.2.1 \\
\hline EM*VEVIEGGDAMEE & u & 1 & $\beta 2 a$ & Solyc04g024420.2.1 \\
\hline EMVEVIEGGDAMEE & u & 1 & $\beta 2 a$ & Solyc04g024420.2.1 \\
\hline DGVILGADTR & a & 3 & $\beta 2 b$ & Solyc05g013820.2.1 \\
\hline VVTSLTLLK & u & 18 & $\beta 2 b$ & Solyc05g013820.2.1 \\
\hline ATEGPIVADK & $\mathrm{a}$ & 16 & $\beta 2 b$ & Solyc05g013820.2.1 \\
\hline EIVQVIEGGDAM $\star E E$ & u & 11 & $\beta 2 b$ & Solyc05g013820.2.1 \\
\hline GNTEYLR & u & 20 & $\beta 2 b$ & Solyc05g013820.2.1 \\
\hline KTEVLLTK & a & 21 & $\beta 2 b$ & Solyc05g013820.2.1 \\
\hline NHLSPNPR & u & 1 & $\beta 2 b$ & Solyc05g013820.2.1 \\
\hline EIVQVIEGGDAMEE & $\mathrm{u}$ & 9 & $\beta 2 b$ & Solyc05g013820.2.1 \\
\hline ATEGPIVADKNCEK & a & 6 & $\beta 2 b$ & Solyc05g013820.2.1 \\
\hline TEVLLTK & a & 6 & $\beta 2 b$ & Solyc05g013820.2.1 \\
\hline YDLSVEEAAELAR & u & 30 & $\beta 5$ & Solyc05g056160.2.1 \\
\hline
\end{tabular}




$\begin{array}{lcccc}\text { GPGLYYVDSEGGR } & \mathrm{u} & 21 & \beta 5 & \text { Solyc05g056160.2.1 } \\ \text { LLANILYSYR } & \mathrm{u} & 22 & \beta 5 & \text { Solyc05g056160.2.1 } \\ \text { GGVMVAADSR } & \mathrm{u} & 15 & \beta 5 & \text { Solyc05g056160.2.1 } \\ \text { GGVM*VAADSR } & \mathrm{u} & 21 & \beta 5 & \text { Solyc05g056160.2.1 } \\ \text { ASMGGYISSQSVK } & \mathrm{u} & 13 & \beta 5 & \text { Solyc05g056160.2.1 } \\ \text { ASM*GGYISSQSVK } & \mathrm{u} & 12 & \beta 5 & \text { Solyc05g056160.2.1 } \\ \text { GM*GLSVGTM*IAGWDEK } & \mathrm{u} & 5 & \beta 5 & \text { Solyc05g056160.2.1 } \\ \text { GMGLSVGTM*IAGWDEK } & \mathrm{u} & 5 & \beta 5 & \text { Solyc05g056160.2.1 } \\ \text { FSVGSGSPYAYGVLDNGYR } & \mathrm{u} & 6 & \beta 5 & \text { Solyc05g056160.2.1 } \\ \text { GMGLSVGTMIAGWDEK } & \mathrm{u} & 1 & \beta 5 & \text { Solyc05g056160.2.1 }\end{array}$

(u) unique peptide; (a) ambiguous peptide; (PSM) peptide spectral count; $\mathrm{M}^{\star}$, oxidized methionine

These data are a summary of all the detected peptides from all the analyzed spots taken from both 2D gels, extracted from MaxQuant. 
Table S3 Renamed samples from 2D gels

\section{$0 \mathrm{mM} \mathrm{NaCl}$}

$\begin{array}{ll}\text { Fig4A } & \text { Database } \\ 1 & \text { ACE_0037_JK01 } \\ 2 & \text { ACE_0037_JK02 } \\ 3 & \text { ACE_0037_JK03 } \\ 4 & \text { ACE_0037_JK04 } \\ 5 & \text { ACE_0037_JK05 } \\ 6 & \text { ACE_0037_JK06 } \\ 7 & \text { ACE_0037_JK07 } \\ 8 & \text { ACE_0037_JK08 } \\ 9 & \text { ACE_0037_JK09 } \\ 10 & \text { ACE_0037_JK10 } \\ 11 & \text { ACE_0037_JK11 } \\ 12 & \text { ACE_0037_JK12 } \\ 13 & \text { ACE_0037_JK13 } \\ 14 & \text { ACE_0037_JK14 }\end{array}$

\section{$250 \mathrm{mM} \mathrm{NaCl}$}

Fig4A

Database

1

2

3

4

5

6

7

8

9

10

11

12

13

14
ACE 0037 JK15

ACE_0037_JK16

ACE_0037_JK17

ACE_0037_JK18

ACE_0037_JK19

ACE_0037_JK20

ACE_0037_JK21

ACE_0037_JK22

ACE_0037_JK23

ACE_0037_JK24

ACE_0037_JK25

ACE_0037_JK26

ACE_0037_JK27

ACE_0037_JK28 


\section{List of publications}

\subsection{Papers}

\subsubsection{Papers related to the thesis}

Kovács J, Poór P, Kaschani F, Chandrasekar B, Hong T, Misas-Villamil J, Xin BT, Kaiser M, Overkleeft H, Tari I and van der Hoorn RAL (2017) Proteasome activity profiling uncovers alteration of catalytic $\beta 2$ and $\beta 5$ subunits of the stress-induced proteasome during salinity stress in tomato roots. Frontiers in Plant Science 8:107. (IF: 4.495)

Kovács $\mathrm{J}$ and van der Hoorn RAL (2016) Twelve ways to confirm targets of activitybased probes in plants. Bioorganic \& Medicinal Chemistry 24:3304-3311. (IF: 2.923)

Poór P, Borbély P, Kovács J, Papp, A, Szepesi Á, Takács Z and Tari I (2014) Opposite extremes in ethylene/nitric oxide ratio induce cell death in cell suspension culture and in root apices of tomato exposed to salt stress. Acta Biologica Hungarica 65: 428-438, DOI: 10.1556/ABiol.65.2014.4. (IF: 0.97)

\subsubsection{Additional papers}

Misas-Villamil JC, Van der Burgh AM, Grosse-Holz F, Pages M, Kovács J, Kaschani F, Schilasky S, Emron Khan Emon A, Ruben M, Kaiser M, Overkleeft HS and van der Hoorn RAL (2017) Subunit-selective proteasome activity profiling uncovers uncoupled proteasome subunit activities during bacterial infections. The Plant Journal TPJ-00974-2016. (IF: 5.468)

Shindo T, Kaschani F, Yang F, Kovács J, Tian F, Kourelis J, Hong TN, Colby T, Shabab M, Chawla R, Kumari S, Ilyas M, Hörger AC, Alfano JR and van der Hoorn RAL (2016) Screen of non-annotated small secreted proteins of Pseudomonas syringae reveals a virulence factor that inhibits tomato immune proteases. PLoS Pathogens. 12: e1005874. (IF: 7.64)

Kovács J, Péter Poór, Szepesi Á and Tari I (2016) Salicylic acid induced cysteine protease activity during programmed cell death in tomato plants. Acta Biologica Hungarica 67: 148-158. (IF: 0.605) 
Poór P, Kovács J, Borbély P, Takács Z, Szepesi Á and Tari I (2015) Salt stressinduced production of reactive oxygen- and nitrogen species and cell death in the ethylene receptor mutant Never ripe and wild type tomato roots. Plant Physiology and Biochemistry, 97: 313322. (IF: 2.93)

Poór P, Kovács J, Szopkó D and Tari I (2013) Ethylene signaling in salt stress- and salicylic acid-induced programmed cell death in tomato suspension cells. Protoplasma 250: 273-284. (IF: 3.171)

Tari I, Guóth A, Benyó J, Kovács J, Poór P and Wodala B (2010) The roles of ABA, reactive oxygen species and nitric oxide in root growth during osmotic stress in wheat: comparison of a tolerant and a sensitive variety. Acta Biologica Hungarica 209-216. (IF: $0.793)$

\subsection{Conference announcement}

Poór P, Kovács J, Borbély P, Takács Z, Szepesi Á and Tari I (2015) Sóstressz indukált változások a reaktív oxigén és nitrogénformák akkumulációjában etilénreceptor mutáns Never ripe és vad típusú paradicsomban. A Magyar Szabadgyök-Kutató Társaság VIII. Kongresszusa, Budapest, 2015. november 5-6. Absztraktfüzet, pp. 32.

Szepesi Á, Borbély P, Gellért A, Hurton Á, Kovács J, Poór P, Takács Z and Tari I (2014) Impact of aminoguanidine on NO content and polyamine catabolism in salicylic acid treated tomato plants In: Jeremy Astier, Christian Lindermayr (szerk.)5th Plant NO Club Meeting. Konferencia helye, ideje: München, Németország, 2014.07.24-2014.07.25. München: p. 50.

Szepesi Á, Borbély P, Gellért A, Hurton Á, Kovács J, Poór P, Takács Z and Tari I (2014) Short term analysis of salt stress induced polyamine catabolism affected by aminoguanidine and diphenylene iodonium iodide in tomato. In: Tari I (szerk.) 11th Congress of the Hungarian Society of Plant Biology: Book of Abstracts. Konferencia helye, ideje: Szeged, Magyarország, 2014.09.27-2014.09.29. MTA Szegedi Biológiai Központ, p. 54.

Tari I, Borbély P, Poór P, Szepesi Á and Kovács J (2014) Modification of salt stressinduced programmed cell death by exogenous nitric oxide in tomato In: Tari I. (szerk.) 11th Congress of the Hungarian Society of Plant Biology: Book of Abstracts. Konferencia 
helye, ideje: Szeged, Magyarország, 2014.09.27-2014.09.29. MTA Szegedi Biológiai Központ, p. 19.

Kovács J, Poór P, Patyi G, Borbély P, Szepesi Á, Takács Z and Tari I (2014) Investigation of salt stress induced changes in cysteine protease activity in abscisic aciddeficient sitiens tomato (Solanum lycopersicum) mutant. In: Tari I. (szerk.) 11th Congress of the Hungarian Society of Plant Biology: Book of Abstracts. Konferencia helye, ideje: Szeged, Magyarország, 2014.09.27-2014.09.29. MTA Szegedi Biológiai Központ, p. 45.

Borbély P, Poór P, Kovács J, Takács Z, Patyi G, Szepesi Á and Tari I (2014) Exogenous sodium nitroprusside alleviates salt-induced changes in photosynthesis of tomato leaves. In: Tari I. (szerk.) 11th Congress of the Hungarian Society of Plant Biology: Book of Abstracts. Konferencia helye, ideje: Szeged, Magyarország, 2014.09.27-2014.09.29. MTA Szegedi Biológiai Központ, p. 61.

Poór P, Gallé Á, Kovács J, Takács Z, Borbély P, Patyi G, Chounramany S, Szepesi Á and Tari I (2014) Analysis of light dependent cis-regulatory elements of hexokinase genes in tomato (Solanum lycopersicum) In: Tari I (szerk.) 11th Congress of the Hungarian Society of Plant Biology: Book of Abstracts. Konferencia helye, ideje: Szeged, Magyarország, 2014.09.27-2014.09.29. MTA Szegedi Biológiai Központ, p. 59.

Poór P, Kovács J, Borbély P, Szepesi Á, Gallé Á and Tari I (2013) Regulation of leaf senescence induced by salt stress. 6th European Workshop on Leaf Senescence, 14-18th October 2013, INRA Versailles France, Book of Abstracts, pp. 139

Szepesi Á, Borbély P, Kovács J, Poór P, Tóth Sz, Takács Z and Tari I (2013) Polyamine catabolism in tomato leaves exposed to salt stress. 6th European Workshop on Leaf Senescence, 14-18th October 2013, INRA Versailles France, Book of Abstracts, pp. 180 .

Poór P, Kovács J, Szepesi Á and Tari I (2013) Salicylic acid induced cysteine protease activity during programmed cell death in tomato plants. In: Plant Diseases and Resistance Mechanisms. Konferencia helye, ideje: Vienna, Ausztria, 2013.02.20-2013.02.22. Vienna: p. 62. 132 
Poór P, Kovács J, Szopkó D and Tari I (2012) Ethylene signaling in salt stress- and salicylic acid-induced programmed cell death in tomato suspension cells. VIPCA (Vienna International Plant Conference Association) VIPCA (Vienna International Plant Conference Association) International Conference. Plant Abiotic Stress Tolerance II. Vienna, Austria, February 22-25, 2012, Programme and Abstracts, pp. 55. 


\section{Acknowledgements}

I would like to thank Dr. Miklósné Görgényi Dr. Irma Tari for all the support that she provided me throughout my PhD period at the Department of Plant Biology in the University of Szeged.

I would like to thank Professor Renier van der Hoorn for all the support, suggestions and help to complete the experimental part of my thesis in his Plant Cheemtics laboratory at the MPI in Cologne and at the Department of Plant Sciences in the University of Oxford.

Special thanks to Dr. Péter Poór for giving his extremly useful advices and being my pillar of strength and becoming a great friend through my PhD.

Big thanks to all the members of the van der Hoorn lab, past and present, especially to Balakumaran Chandrasekar and Tram Hong who were my excellent teachers and became very good friends during my stay in Cologne and in Oxford!

Also I have been having good support from the people all around the Department of Plant Sciences in Szeged specially to my office-mate Dr. Attila Pécsváradi and I would like to personally thanks to the Technicians who throughout made easier and enjoyable my work in the lab specially to Ibolya Szabó Kispálné, Eta Bécs Attiláné, Mária Hegyesiné Tandari and Ursula Pyzio.

I would like to thank to my friends who were always there for me.

Special thanks to my fiance who was always pacient and supportive and really encouraged me not to give up my dreams even if it meant that I have to work in another country. It was worth its price.

I really appreciate the support from my family without them I would not be on this stage of my life. I still feel like the day I moved to Szeged but at the same time it was a long way to complete what I aimed at my first day in the University. First, it was a dream but it became reality. 


\section{Declaration}

\section{Declaration}

I, the undersigned Dr. Miklósné Görgényi Dr. Irma Tari, certify that Judit Kovács contributed to the implementation of the following publication "Opposite extremes in ethylene/nitric oxide ratio induce cell death in cell suspension culture and in root apices of tomato exposed to salt stress".

The above mentioned scientific evidences have not been published elsewhere, so far, and it is not going to be used by other PhD candidates.

Szeged,

Dr. Mikıósné Görgényi Dr. Irma Tari (Supervisor, Corresponding author)

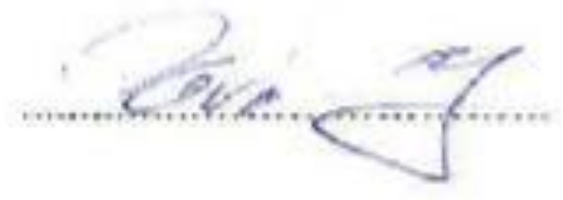

Judit Kovács doctoral (Ph.D.) candidate 


\section{Declaration}

I the undersigned Profestor Renier A, L. yan der Hoom, certify that Judit Kováç contrlbuted to the implementation of the folowng publications "Protersome activity prokling uncovers alteration of salalyfic $\beta 2$ and $\beta 5$ subunlts of the stress-Induced proteasome during salinity stress in tomato roots" and Twelve ways ta confirm targels of activity-based probes in planta".

The above mantioned scientific evidencss have not besn published etsewhere, so far, and it is not going to ke used by other Pin candidates

oxfard, ... $10 \ldots 3017$
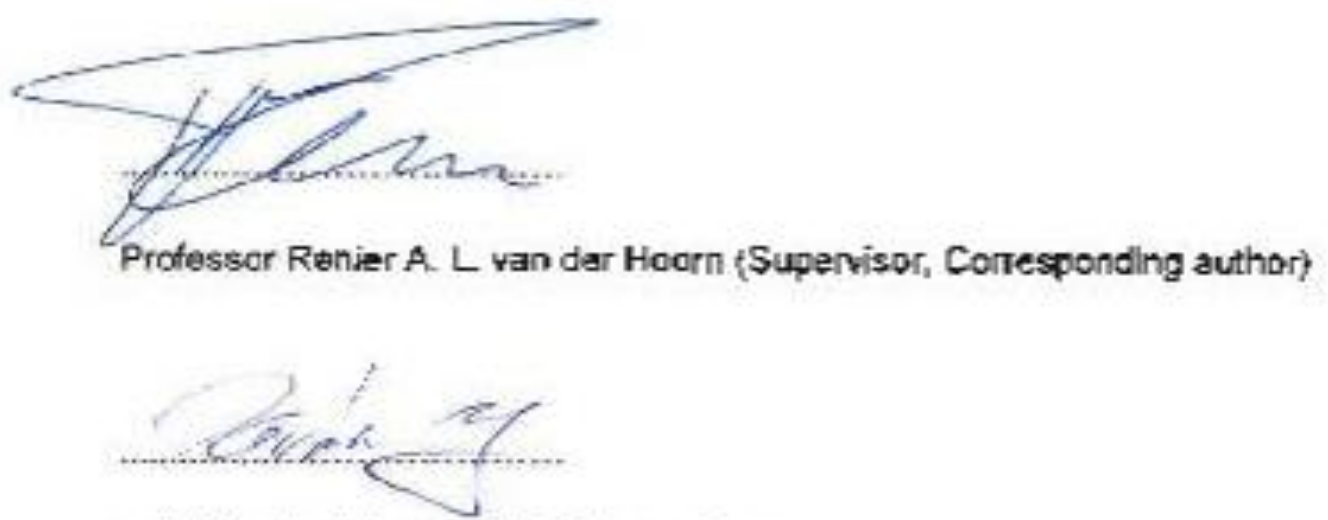

Juelit Kowács (doctoral (Ph. D.) candidate 